\title{
Archaeology at the Alamodome: Investigations of a San Antonio Neighborhood in Transition, Volume II: Excavations and Artifact Distribution Analysis
}

Anne A. Fox

Center for Archaeological Research

Marcie Renner

Center for Archaeological Research

Robert J. Hard

Department of Anthropology, University of Texas at San Antonio

Follow this and additional works at: https://scholarworks.sfasu.edu/ita

Part of the American Material Culture Commons, Archaeological Anthropology Commons, Environmental Studies Commons, Other American Studies Commons, Other Arts and Humanities Commons, Other History of Art, Architecture, and Archaeology Commons, and the United States History Commons

Tell us how this article helped you.

This Article is brought to you for free and open access by the Center for Regional Heritage Research at SFA ScholarWorks. It has been accepted for inclusion in Index of Texas Archaeology: Open Access Gray Literature from the Lone Star State by an authorized editor of SFA ScholarWorks. For more information, please contact cdsscholarworks@sfasu.edu. 
Archaeology at the Alamodome: Investigations of a San Antonio Neighborhood in Transition, Volume II: Excavations and Artifact Distribution Analysis

\section{Creative Commons License}

(c) (1) (8)

This work is licensed under a Creative Commons Attribution-NonCommercial 4.0 International License 


\section{Archaeology at the Alamodome: Investigations of a San Antonio Neighborhood in Transition}

edited by Anne A. Fox, Marcie Renner, and Robert J. Hard

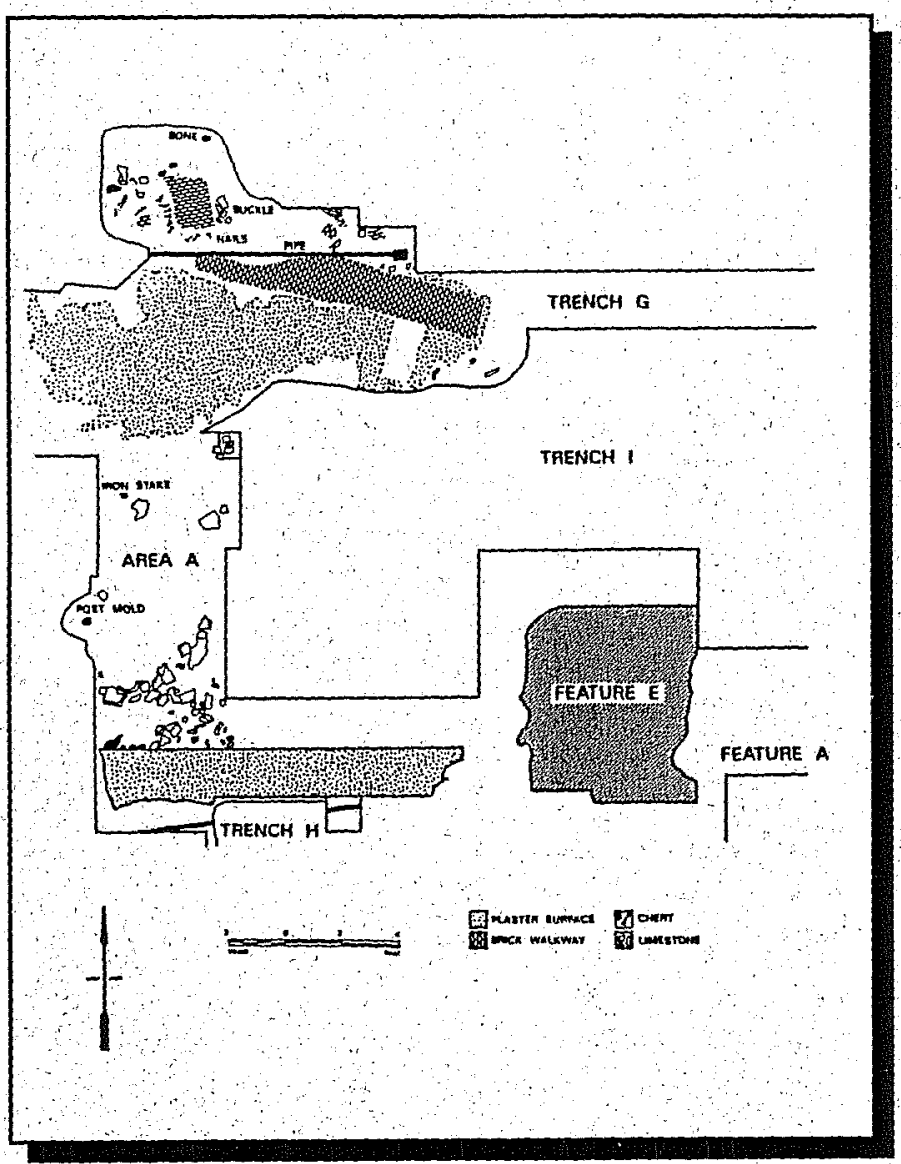

Volume II

Excavations and Artifact Distribution Analysis

G. Kenneth Wright contributors:

Kevin J. Gross and Michael B. Collins

Center for Archaeological Research. The University of Texas at San Antonio Archaeological Survey Report, No. 237, 1997 



\title{
Archaeology at the Alamodome: Investigations of a San Antonio Neighborhood in Transition
}

\author{
edited by Anne A. Fox, Marcie Renner, and Robert J. Hard
}

\author{
Volume II
}

\section{Excavations and Artifact Distribution Analysis}

\author{
G. Kenneth Wright
}

contributors:

Kevin J. Gross and Michael B. Collins

Robert J. Hard, Jack D. Eaton, and Anne A. Fox, Principal Investigators

Texas Antiquities Permit Numbers 900, 930 and 982

๑copyright

Center for Archaeological Research

The University of Texas at San Antonio

Archaeological Survey Report, No. 237 
The following information is provided in accordance with the General Rules of Practice and Procedure, Chapter 41.11 (Investigative Reports), Texas Antiquities Committee:

1. Type of investigation: Survey, testing, and mitigation

2. Project name: Alamodome

3. County: Bexar

4. Principal investigators: Robert J. Hard, Jack D. Eaton, and Anne A. Fox

5. Name and location of sponsoring agency: City of San Antonio, P.O. Box 839966, San Antonio, Texas 782833966

6. Texas Antiquities Committee Permit Nos.: 900, 932, and 982

7. Published by the Center for Archaeological Research, The University of Texas at San Antonio, San Antonio, Texas 78249-0658, 1997

A list of publications offered by the Center for Archaeological Research is available. Call (210) 458-4378; write to the Center for Archaeological Research, The University of Texas at San Antonio, 6900 N. Loop 1604 W., San Antonio, Texas 78249-0658; e-mail to car@lonestar.utsa.edu; or visit CAR's Web site at http://www.csbs. utsa.edu/research/car/index.htm. 


\section{Contents}

List of Figures $\ldots \ldots \ldots \ldots \ldots \ldots \ldots \ldots \ldots \ldots \ldots \ldots \ldots \ldots \ldots \ldots \ldots \ldots$

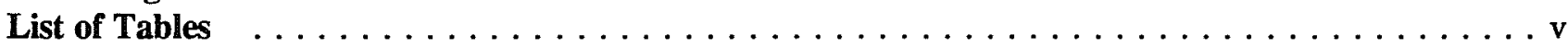

Acknowledgments $\ldots \ldots \ldots \ldots \ldots \ldots \ldots \ldots \ldots \ldots \ldots \ldots \ldots \ldots \ldots \ldots \ldots$

Foreword $\ldots \ldots \ldots \ldots \ldots \ldots \ldots \ldots \ldots \ldots \ldots \ldots \ldots \ldots \ldots \ldots \ldots$ vii

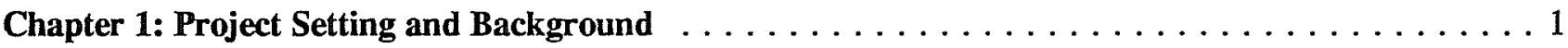

Chapter 2: Theoretical Framework $\ldots \ldots \ldots \ldots \ldots \ldots \ldots \ldots \ldots \ldots \ldots \ldots \ldots \ldots \ldots \ldots$

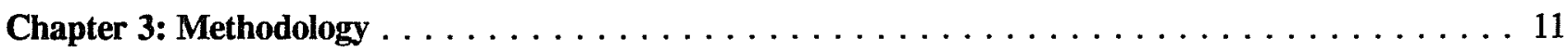

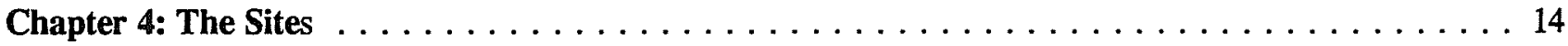

Chapter 5: Artifact Frequency Analysis $\ldots \ldots \ldots \ldots \ldots \ldots \ldots \ldots \ldots \ldots$

Chapter 6: Identification of Site Formation Processes at the Alamodome

Kevin J. Gross . . . . . . . . . . . . . . . . . . . . . . . . . . . . . . 124

Chapter 7: Conclusions and Recommendations $\ldots \ldots \ldots \ldots \ldots \ldots$

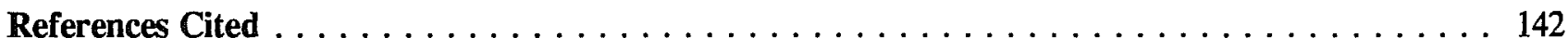

Appendix A: Artifact Classes Constituting Major Groups . . . . . . . . . . . . . . 146

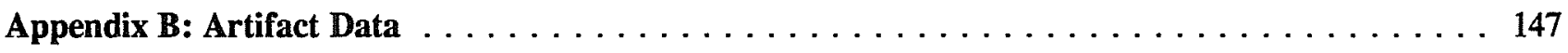

Appendix C: Quaternary Geomorphology of the Alamodome Project Area

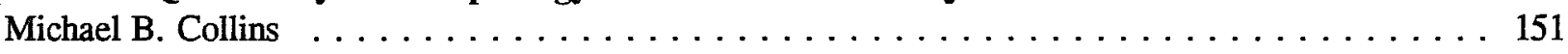




\section{Figures}

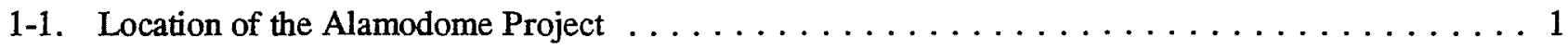

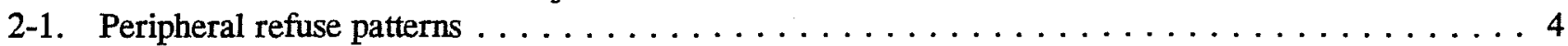

2-2. General model for a circular settlement . . . . . . . . . . . . . . . . . 5

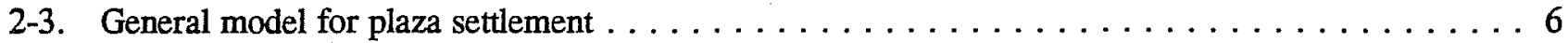

2-4. Example of a repeated double linear settlement, U.S. urban . . . . . . . . . . . . . 6

4-1. Alamodome Project site and geomorphic trench locations . . . . . . . . . . . . . 15

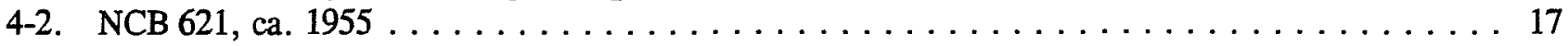

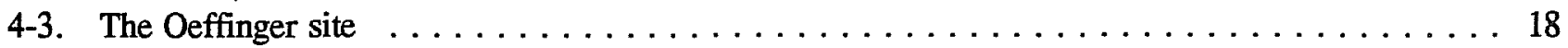

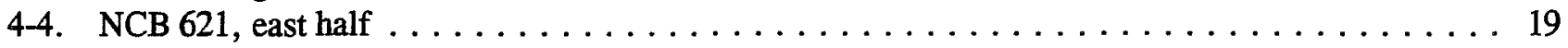

4-5. NCB 621 east; sites 41BX881, 41BX882, 41BX883, and 41BX897 . . . . . . . . . . . 20

4-6. 41BX881, spatial frequency of artifacts across the site . . . . . . . . . . . . . 21

4-7. 41BX882, spatial frequency of artifacts across the site $\ldots \ldots \ldots \ldots \ldots \ldots \ldots$

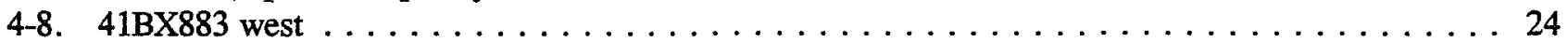

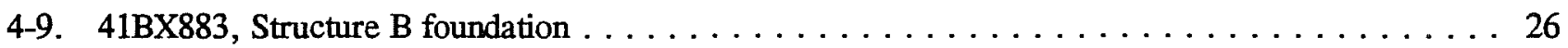

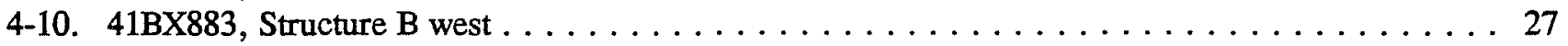

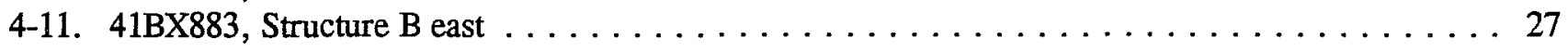

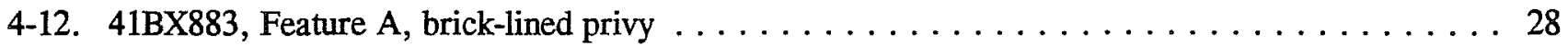

4-13. 41BX883 west, spatial artifact frequency across the site . . . . . . . . . . . . . . . 29

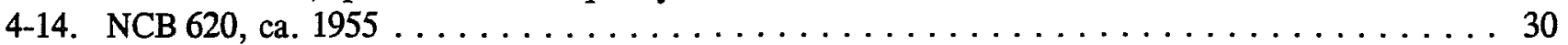

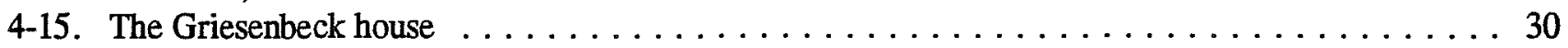

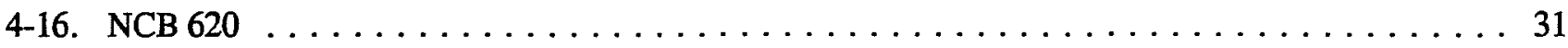

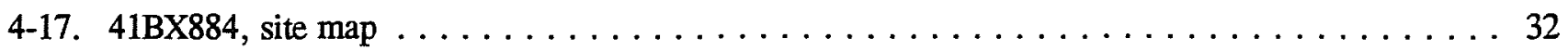

4-18. 41BX884, remnants of piers from former house annex $\ldots \ldots \ldots \ldots \ldots \ldots$

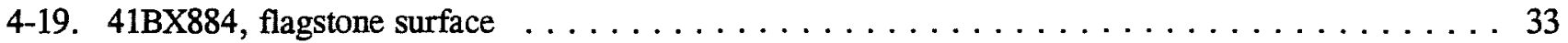

4-20. 41BX884, artifact spatial frequency across the site . . . . . . . . . . . . . . 34

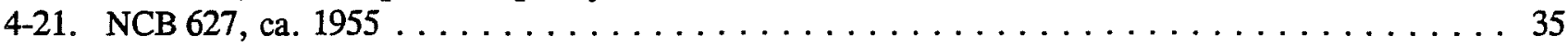

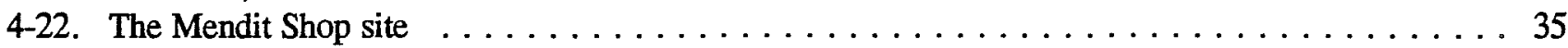

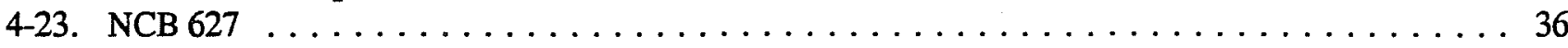

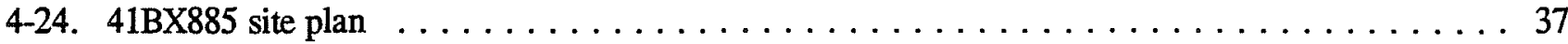

4-25. 41BX885, spatial frequency of artifacts across the site $\ldots \ldots \ldots \ldots \ldots \ldots \ldots$

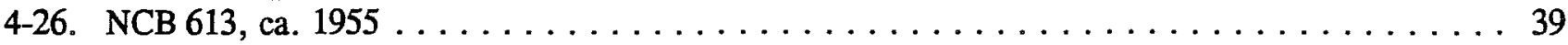

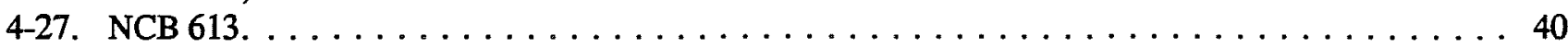

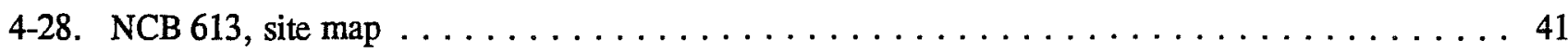

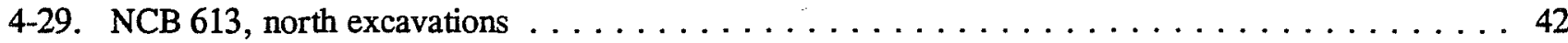

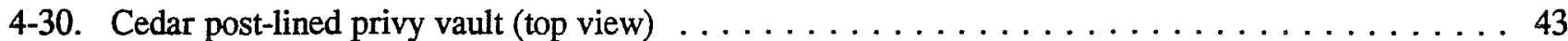

4-31. Cedar post-lined privy vault, sectioned by Trench B . . . . . . . . . . . . . . . 43

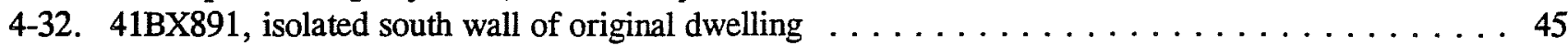

4-33. 41BX891, Feature $A$, midden deposit . . . . . . . . . . . . . . . . . . 45

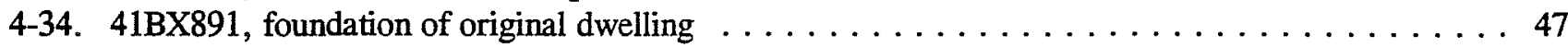

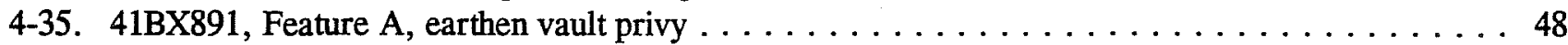

4-36. 41BX892, Trench A extension, Feature A, brick-lined privy vault . . . . . . . . . . . . 48

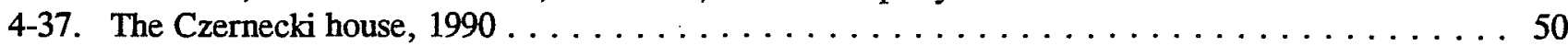

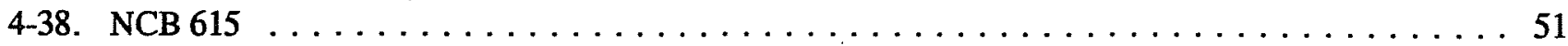

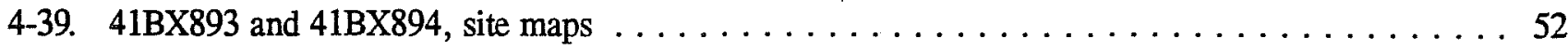

4-40. 41BX893, spatial frequency of artifacts across the site $\ldots \ldots \ldots \ldots \ldots \ldots$ 
4-41. The Garza Store . . . . . . . . . . . . . . . . . . . . . . 55

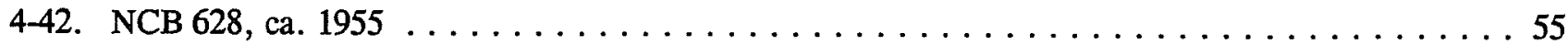

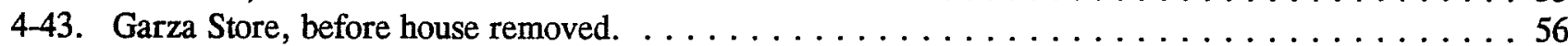

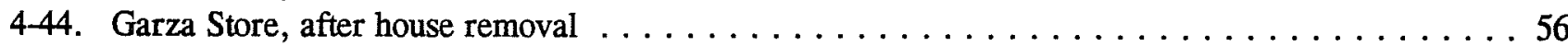

4-45. NCB 628, northwest corner. . . . . . . . . . . . . . . . . . . . . 57

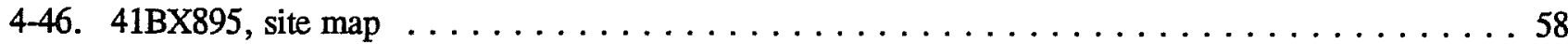

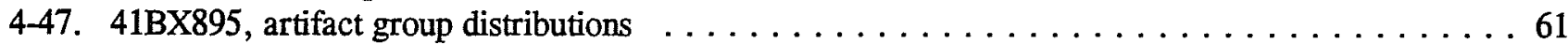

4-48. 41BX895, spatial frequency of artifacts (Phase II) across site . . . . . . . . . . . . 61

4-49. The Demazieres House . . . . . . . . . . . . . . . . . . . . . . . 62

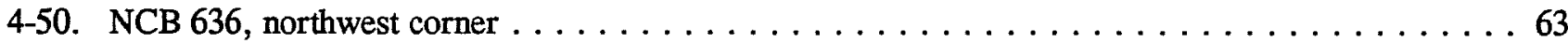

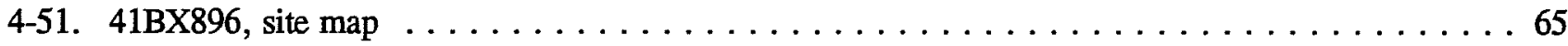

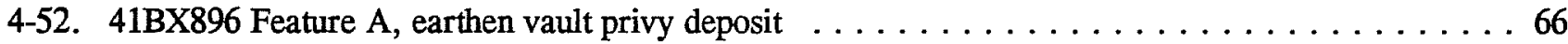

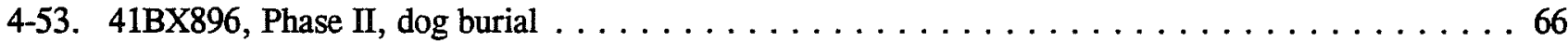

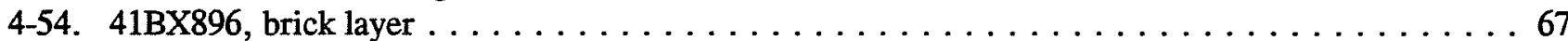

4-55. Excavation Block A . . . . . . . . . . . . . . . . . . . . . . . . . 69

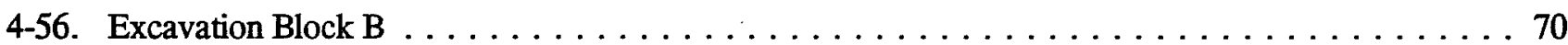

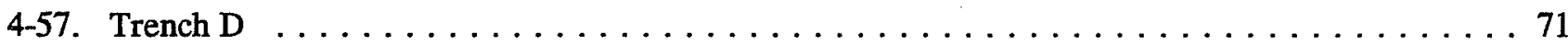

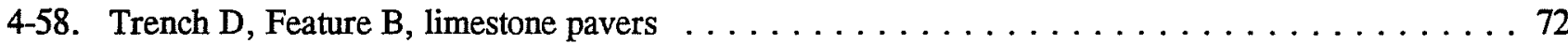

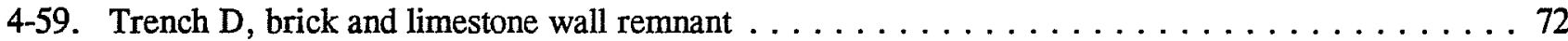

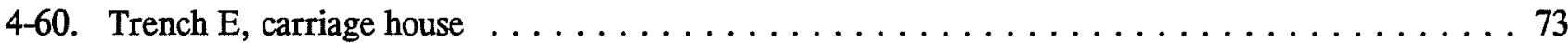

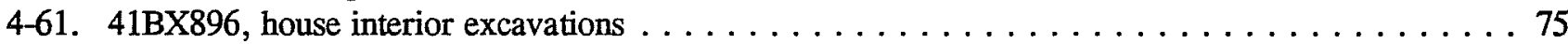

4-62. 41BX896, spatial frequency across the site . . . . . . . . . . . . . . . . . . . 79

4-63. 41BX896 spatial frequencies of artifacts based on shovel test data $\ldots \ldots \ldots \ldots$. . . . . . 79

4-64. Plan map of William Webb House foundation $\ldots \ldots \ldots \ldots \ldots \ldots \ldots$

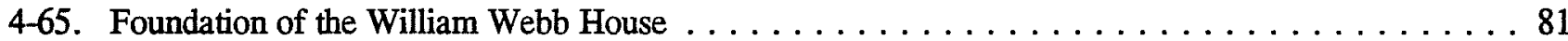

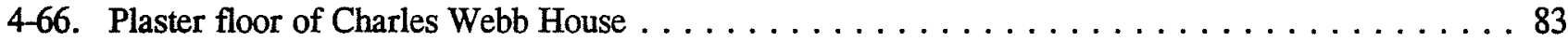

4-67. North/south trenches excavated on 41 BX897 (south) . . . . . . . . . . . . . . . . . . . 84

4-68. Plaster surface of Charles Webb House, laid in several layers. . . . . . . . . . . . . . 85

4-69. Brick walkway and south side of plaster surface (kitchen) $\ldots \ldots \ldots \ldots \ldots$

4-70. Limestone well surface and north side of plaster surface (kitchen) $\ldots \ldots \ldots \ldots$

4-71. Plaster outline of small structure in southeast area of $41 \mathrm{BX} 897 \ldots \ldots \ldots \ldots \ldots$

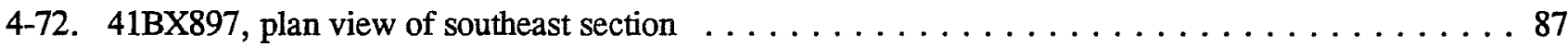

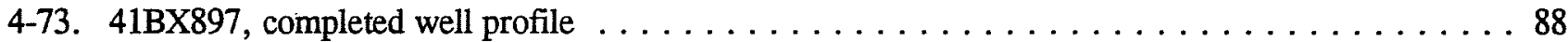

4-74. Expansion trench excavated to approach well face $\ldots \ldots \ldots \ldots \ldots \ldots \ldots \ldots$

4-75. Blue crow's-foot edgeware from material composing the well structure . . . . . . . . . . 90

4-76. NCB 622 (41BX900) . . . . . . . . . . . . . . . . . . . . . . . 91

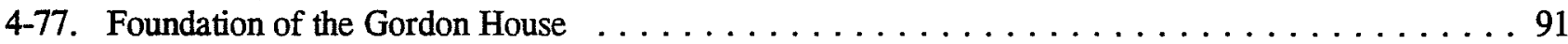

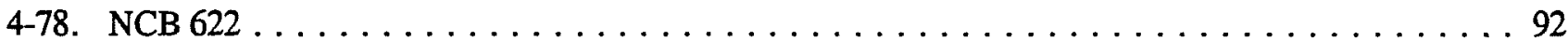

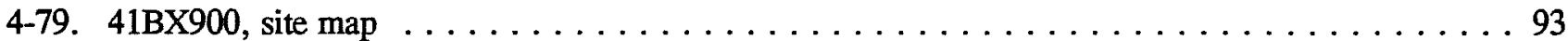

4-80. NCB 636; resubdivision of lots $10-15$, filed December $20,1918 \ldots \ldots \ldots \ldots$. . . . . . . 98

4-81. NCB 636 (eastern half) . . . . . . . . . . . . . . . . . . . . . . . . . 99

4-82. Runge Street area excavation map . . . . . . . . . . . . . . . . . . . . 100

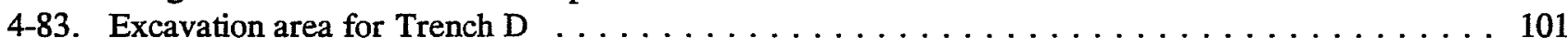

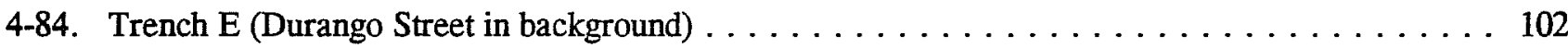

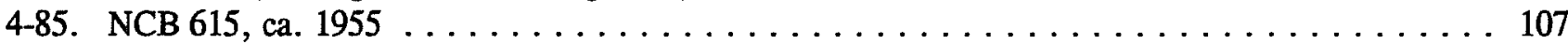

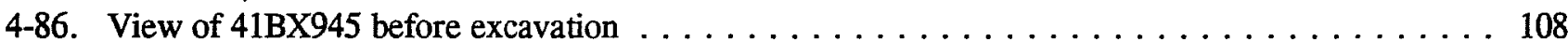

4-87. 41BX945 site plan . . . . . . . . . . . . . . . . . . . . . . . . . . 109

4-88. Top of Feature A, Limestone-lined privy vault $\ldots \ldots \ldots \ldots \ldots \ldots \ldots$

4-89. Interior view of Feature $\mathrm{A}$, limestone-lined privy vault $\ldots \ldots \ldots \ldots \ldots \ldots$

4-90. Feature $\mathrm{C}$, drain, north/south extension $\ldots \ldots \ldots \ldots \ldots \ldots \ldots \ldots$ 
4-91. Top view of Feature E, limestone cistern . . . . . . . . . . . . . . . . . . . 113

4-92. Feature I, Fireplace hearth located in dwelling basement . . . . . . . . . . . . . . 113

4-93. Fully exposed basement of the Pauly House $\ldots \ldots \ldots \ldots \ldots \ldots \ldots \ldots \ldots \ldots$

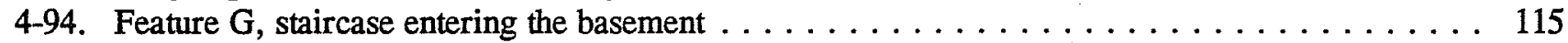

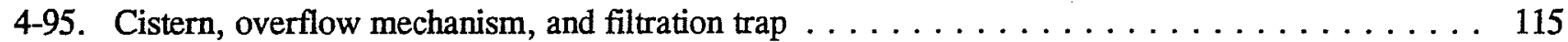

4-96. Spatial frequency of artifacts across site 41BX945, shovel test data only . . . . . . . . . . . 117

6-1. Adjusted residual values for combined sites $\ldots \ldots \ldots \ldots \ldots \ldots \ldots \ldots \ldots \ldots$

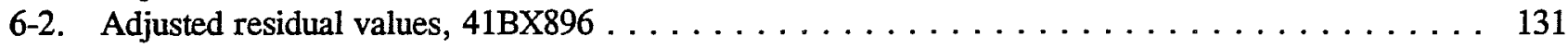

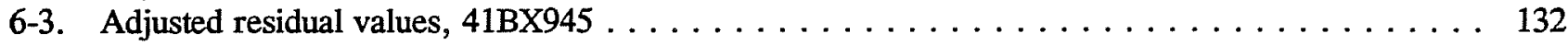

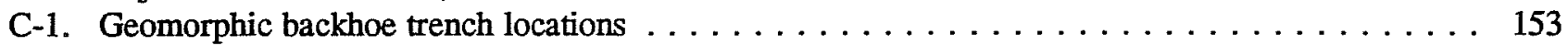

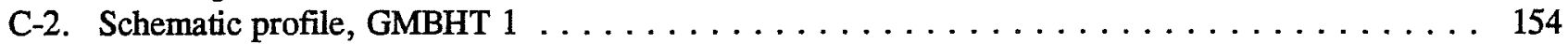

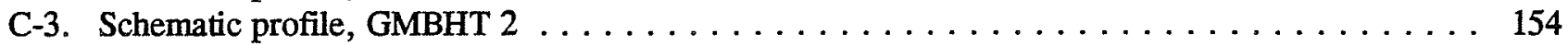

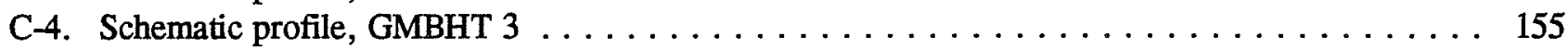

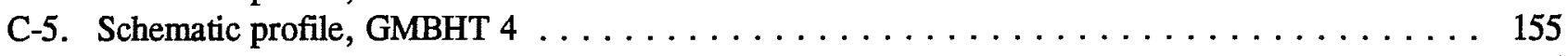

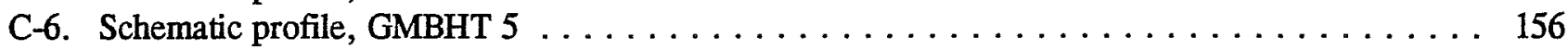

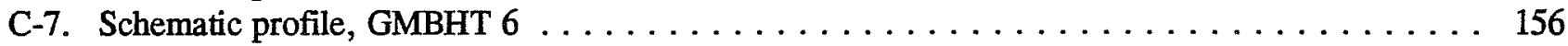




\section{Tables}

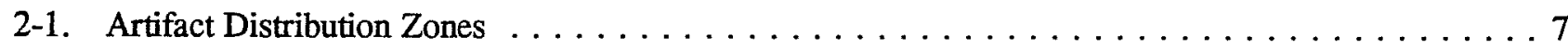

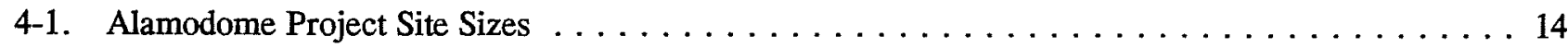

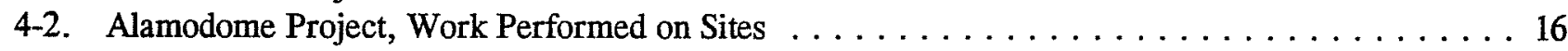

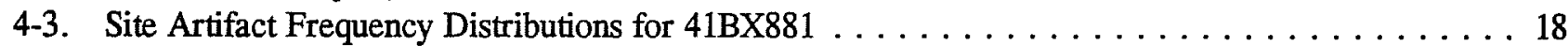

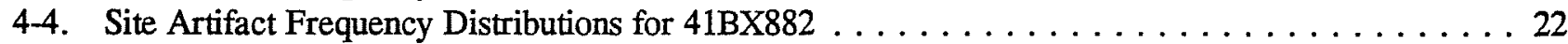

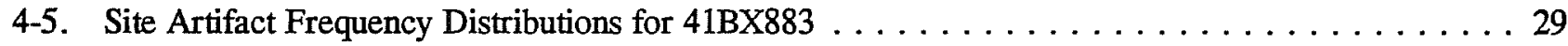

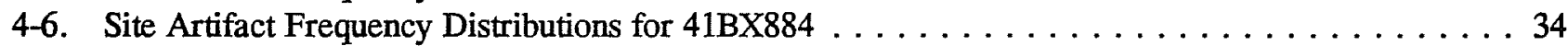

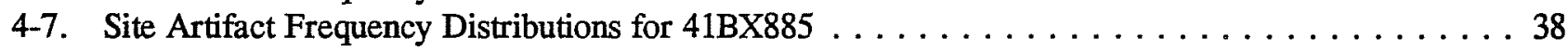

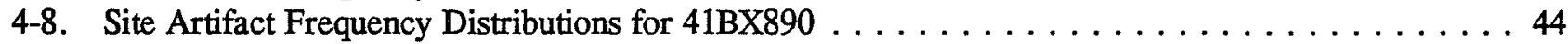

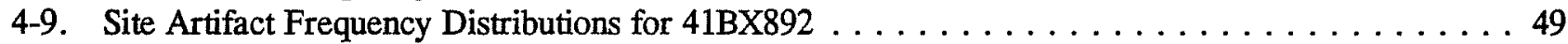

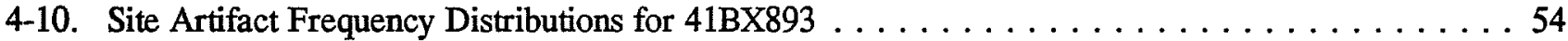

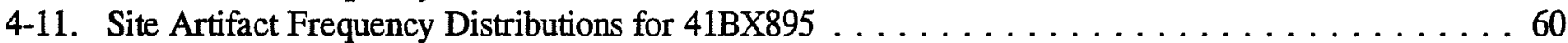

4-12. Site Artifact Frequency Distributions for 41BX896 $\ldots \ldots \ldots \ldots \ldots \ldots \ldots \ldots \ldots \ldots$

4-13. Site Artifact Frequency Distributions for $41 \mathrm{BX} 897 \ldots \ldots \ldots \ldots \ldots \ldots \ldots \ldots \ldots$

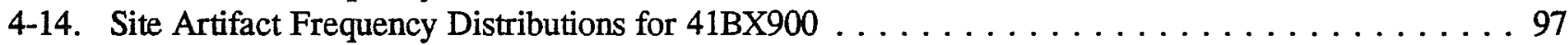

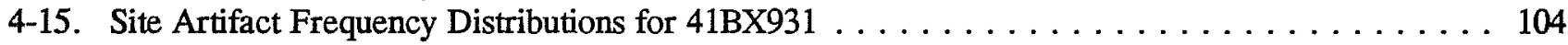

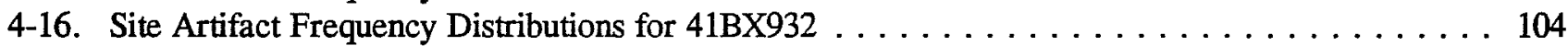

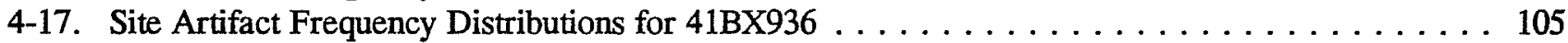

4-18. Site Artifact Frequency Distributions for $41 \mathrm{BXX} 937 \ldots \ldots \ldots \ldots \ldots \ldots \ldots \ldots \ldots \ldots \ldots \ldots$

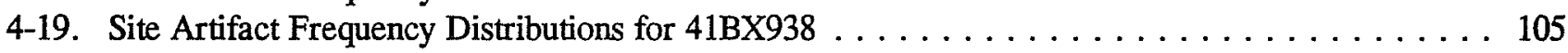

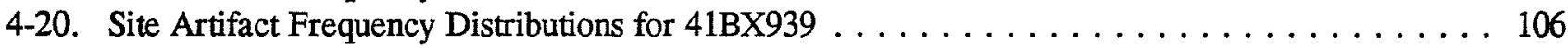

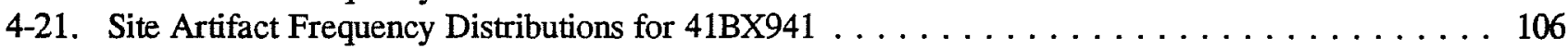

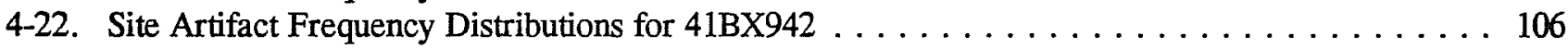

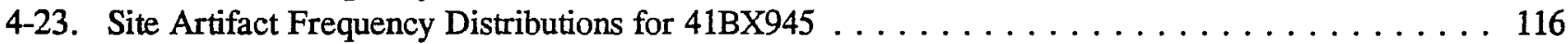

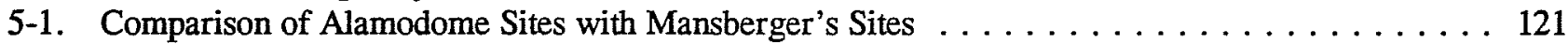

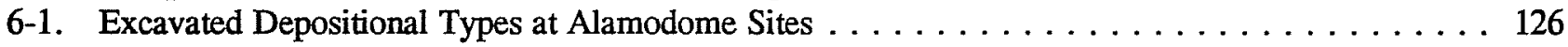

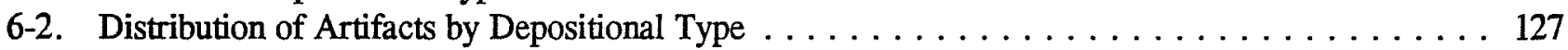

6-3. Proportional Distribution of Artifacts by Depositional Types . . . . . . . . . . . . . 127

6-4. Adjusted Residuals by Artifact Group and Depositional Type for All Excavated

Alamodome Sites (Combined) . . . . . . . . . . . . . . . . . . . . . . . . . . 129

6-5. Adjusted Residuals by Artifact Group and Depositional Type, 41BX896 . . . . . . . . . . . 129

6-6. Adjusted Residuals by Artifact Group and Depositional Type, 41BX945 . . . . . . . . . . . 129

7-1. A Comparison of Sanborn Insurance Map Structures versus what was found Archaeologically during the Alamodome Project . . . . . . . . . . . . . . . . . . . . . . . . 137

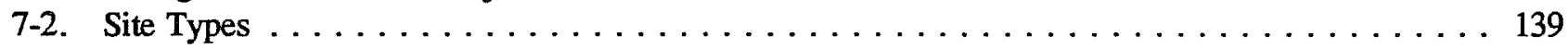

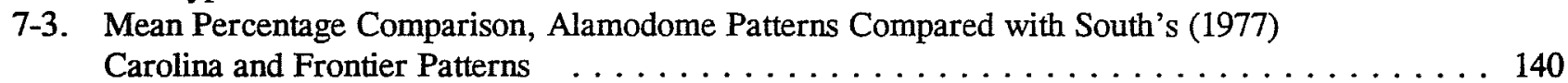

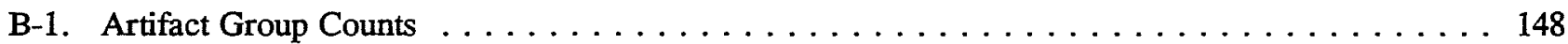

B-2. Artifact Group Percentages . . . . . . . . . . . . . . . . . . 149

B-3. Artifact Frequencies, Site Rank Orders of Artifact Group Percentages $\ldots \ldots \ldots \ldots \ldots \ldots 150$

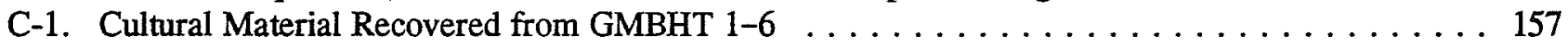




\section{Acknowledgments}

In an endeavor the size and scope of the Alamodome Project, there are many people who helped in so many ways. The city of San Antonio is to be recognized for taking an active role in preserving the cultural heritage of this dynamic, ethnically diverse, downtown neighborhood. Our thanks are extended to Roland Lozano, director of the Office of Dome Development, and the members of his staff, particularly Jelynne Burley and Albert Gutierrez. Bruce Thompson of Day and Zimmerman helped get the fieldwork started.

Robert J. Hard, Jack D. Eaton, and Anne A. Fox served as principal investigators for the project. Sincere thanks go to Anne Fox and Waynne Cox for providing advice throughout the project. Appreciation is also extended to Mark Denton of the Department of Antiquities Protection for his help and guidance.

Thanks are extended to the assistant field director, Maureen Brown, for her continuing help and patient attention to detail, and to a wonderful crew: Palma Buttles, Nora DeLeO, Kevin Gross, JD Henze, Marty Kruger, Don McEwen, Clint McKenzie, Barbara Meissner, Willie Mendez, Robert Merrill, Frances Meskill, Shirley Mock, Sylvia Reyna, David Sternberg, Cynthia Tennis, Herbert Uecker, Lea Worcester, and José Zapata. Many of the abovementioned crew members also assisted in laboratory duties and write-up of the project. Curt Harrell, René Muñoz, Bobby Rector, and Jack Sile provided additional laboratory assistance. Field photography was performed by Maureen Brown and Herbert Uecker. Field site maps were done by the author; final drafting was undertaken by Barbara Meissner and Fernando Londoño. Computer graphics were generated by Barbara Meissner.

Thousands of work hours were performed by volunteers during the course of the project. The University of Texas at San Antonio Anthropology Club; Trinity University, under the sponsorship of Dr. Karen Stothert; and the Southern Texas Archaeological Association were our primary sources of volunteer help. Many thanks to the volunteers: Michele Bucanec, Martha Morrison, Dorothy Lippert, Graham Palmer, Bridget Smart, Burnley "Duke" Smith, Christina
Smith, Gary Smith, Tommy Tomesal, and Doris Tudyk. Wrightway Backhoe Company and our operator Mike Fulghum deserve high praise and many thanks.

Thanks are extended to my thesis committee members-Dr. Thomas Hester (Chair), Dr. Robert J. Hard, and Dr. Richard E. W. Adams-for their help throughout the writeup. Thanks also go to the graduate advisor of record, Dr. Linda Pritchard. Marcie Renner and Anne Fox transformed my thesis into Volume II of the Alamodome series, and Lucy J. Vasquez assisted with the final editing. 


\section{Foreword}

Because of the tremendous scope of the archaeological work and the associated analysis and write-up, the results of the Alamodome Project are presented in three volumes. Volume I contains the background research results, including chapters on the historical setting, the architecture present before demolition began, the oral histories, a study of the black community, and a summary of the structural evolution of the area. This volume, the second of the series, contains a complete description of the archaeological excavations and a distributional analysis of the results, written by Kenneth Wright, the archaeologist in charge of the fieldwork. Also included in Volume II are a study of the site formation processes, undertaken by Kevin Gross, and a geomorphic description of the project area, by Michael Collins. Volume III is comprised of individual reports on the description and analysis of various types of artifactual materials recovered during the project, including ceramics, glass, kitchen and tablewares, dolls and toys, marbles, clothing and personal items, and building materials. Also included in this volume are descriptions and discussions of excavated wells, acequias, and privies and an analysis of the faunal materials.

The temporal scope of these studies is the 100-year period from 1850 to 1950 . This time frame encompasses the period directly after the end of Spanish/Mexican control and the gradual rise of Anglo/German control of the local economy and sociopolitical structure. It is also the time during which the first wave of the Industrial Revolution arrived in Texas, dramatically impacting the history of San Antonio. One goal of the project was to study this impact on the economic and cultural life of one small sector of the city.

\section{Scope of Volume II}

The primary objectives of Volume II are threefold:

1) To describe excavations carried out within the construction area for the Alamodome. Within this objective will be covered structural and stratigraphic evidence to support changes in the use of space, and development of activity areas on the various sites examined over time.

2) To observe the frequencies of major artifact groups derived from the excavation of these sites and, through a pattern recognition process, to develop models relating to the socioeconomic status of the people living within the area and to the site formation processes operating there.

3) To evaluate the effectiveness of Sanborn maps as archaeological tools. 


\section{Chapter 1 \\ Project Setting and Background}

\section{Introduction}

On March 15, 1990, the Center for Archaeological Research (CAR) of The University of Texas at San Antonio (UTSA) contracted with the city of San Antonio's Multipurpose Domed Stadium Development Advisory Committee and VIA Metropolitan Transit Authority to undertake cultural resource investigations of a 16-block (65 acre) area in downtown San Antonio, Texas (Figure 1-1). The area was to be razed for construction of the Alamodome and its associated access and parking. From mid-March to early July 1990 , and periodically thereafter, intensive archival and historical research on the entire project area was carried out by CAR. Architectural recording and assessment of all standing buildings was done by Andrew Perez and Associates. Thirteen oral history interviews with residents, former residents, and officers and employees of business establishments in the general area were recorded and transcribed by

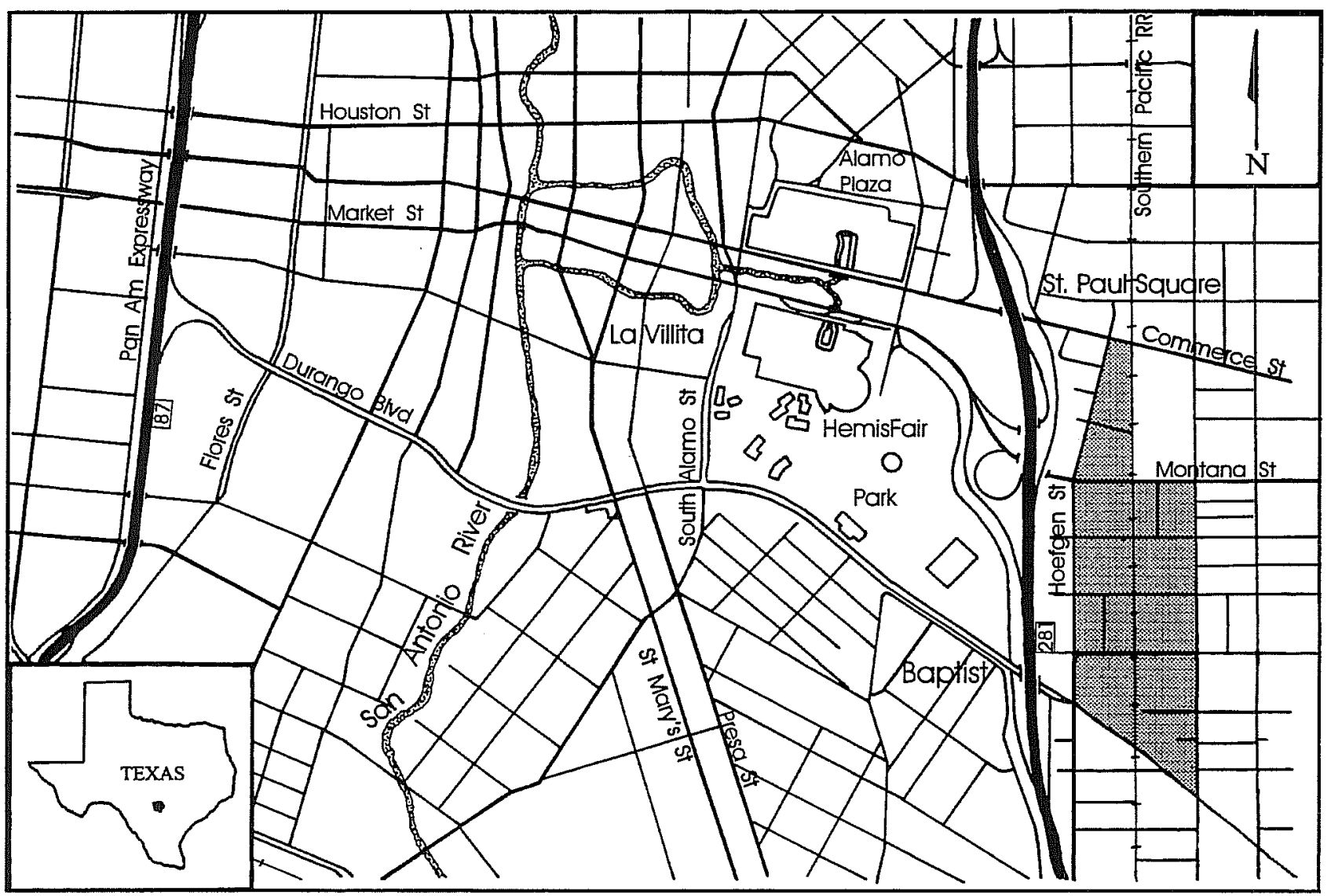

Figure 1-1. Location of the Alamodome Project (shaded area). 
E. L. Fly and Associates. This was the first phase of a multiple-phase project that also included archaeological test excavations during 1991 and 1992. The investigations, carried out under Texas Antiquities Committee permit numbers 900,932 , and 982 , were designed to verify or identify the locations of sites and features within the project area and to sample selected sites and features. The artifacts recovered from the investigations were then processed, cataloged, and analyzed. All artifacts, site records, and administrative records are on file at the CAR laboratory on the campus of UTSA.

\section{Environmental Setting}

The project area rests on a slight slope running downhill north to south across the area. A ridge which runs between Salado Creek to the east and the San Antonio River to the west is topped by three small hills. El Divisadero (elevation $760 \mathrm{ft}$ above mean sea level [amsl]) is located just north of $\mathrm{IH}-35$, and just south of Fort Sam Houston. Dignowitty Hill (elevation $744 \mathrm{ft}$ amsl) is just north of the city cemeteries near Lockwood Park. Harmony Hill (elevation $730 \mathrm{ft}$ amsl) is located just south of the city cemeteries near the corner of Palmetto Avenue and Martin Luther King Street. The project area lies on the western slope (facing the San Antonio River) between Dignowitty and Harmony hills at an elevation of 650-660 ft amsl.

The soil of the area is described by Collins (Appendix C) as Houston Black Clay. This type, defined as a slowly permeable, calcareous clay (Taylor et al. $1991: 20-21)$ is characteristic of upland settings. Naturally occurring flora across this zone includes larger tree species such as live oak, Texas oak, hackberry, elm, walnut, several species of acacia, and pecan (Black and McGraw 1985).

Climatic conditions are characterized by mild winters (continental influences), and hot humid summers (maritime influences). A long growing season averaging 268 frost-free days per year is typical. Average rainfall is 28 inches per year but varies greatly on a year-to-year basis. Short term droughts of several months are common. Rainfall extremes (droughts and floods) are the major limiting climatic factors (Black and McGraw 1985). Historically, the San Antonio River flooded periodically, causing great damage and loss of life. Disastrous floods occurred in 1819 and 1865; a terrible flood in 1921 killed 50 people and destroyed three million dollars worth of property. This led to the construction of Olmos Dam above the river's headwaters to control river flooding (McLemore 1980).

\section{Project Area Background}

The study area comprises approximately 65 acres on the east side of the San Antonio River between Goliad Road and the former Alameda (now Durango and Commerce streets) (Figure 1-1). The western extremity of the project area lies approximately 1,000 varas $(2,770 \mathrm{ft})$ from the San Antonio River at its closest approach.

The area was originally part of the farmlands surrounding the Mission San Antonio de Valero (the Alamo). When the city was incorporated in 1842 by the Republic of Texas, it was given authorization to sell unimproved lands within its jurisdiction. On August 24, 1849, the San Antonio City Council authorized such sales, including the current study area (Cox, Volume I).

Starting in 1845, a program of German immigration into this part of Texas was sponsored by the Society for the Protection of German Immigrants in Texas, under the leadership of Prince Carl of SolmsBraunfels. This led to the establishment of cities such as New Braunfels, Fredericksburg, and Boerne. However, directly on the route to these new communities from Indianola, the major port of immigration, was the city of San Antonio. Many of the new German immigrants viewed the land sales in San Antonio as an opportunity to become established in a city which was, in effect, the crossroads to the frontier. Many initially chose to settle in San Antonio, while others moved to San Antonio after a period of residence in one or more of the other communities (Biesele 1987[1930]). One of the primary areas of settlement in San Antonio for these new German citizens was the area in and around the current HemisFair district, including the area under investigation.

Growth in the area began slowly. Between 1850 and 1860 approximately eight residences were located 
within the study area. All but two were owned by German families; these two were eventually acquired by German families. By 1880 the population of the area was still small: about 15 residences, still primarily German; however, things were changing. In 1877 the railroad reached San Antonio, and the rail line ran through the project area. Industries soon began to locate close to the rail line, attracting additional settlers in search of work to the area. Between 1880 and 1890 the area underwent a boom, growing from 15 to about 53 residences, and saw the establishment of industries such as Alamo Iron Works and Steves Lumber Yard.

With the rise in population came increased ethnic diversity. Over time Hispanic, African-American, Polish, and other ethnic groups settled in the neighborhood as new industries and commercial enterprises developed; however, the general nature of the neighborhood remained basically German until after the turn of the century. 


\section{Chapter 2 \\ Theoretical Framework}

In developing a strategy for excavations in the area of the Alamodome development (an area covering 16 blocks and about 65 acres), one key consideration was how best to employ the limited time and available staff so as to gather as much data as possible, and have that data constitute a valid sample for analysis and interpretation of cultural process in the area. Much of the study draws heavily on methods of pattern recognition and analysis introduced by South (1977) and supported by subsequent works, some utilizing similar methodologies (Jurney and Moir 1987; Lewis 1980; Mansberger 1987)

\section{Patterns of Refuse Disposal}

South (1979) developed a model for refuse disposal around a twentieth-century lowersocioeconomic-class dwelling built on footings-referred to as "pier and beam" construction-that very closely matches many of the types of structures expected in the project area (Figure 2-1). The general premise is that refuse tends to be deposited across a site in three distinct regions:

1) a central region under the house composed of large and small items (cans, bottles, toy parts, junk);

2) an adjacent region composed of small items deposited in a sometimes swept or cleaned zone (ceramics, glass, etc.);

3) a peripheral region composed of large and small artifacts (cans, bottles, ceramics, junk) deposited along site margins, often determined by fence lines or other boundary markers (South 1979:219).

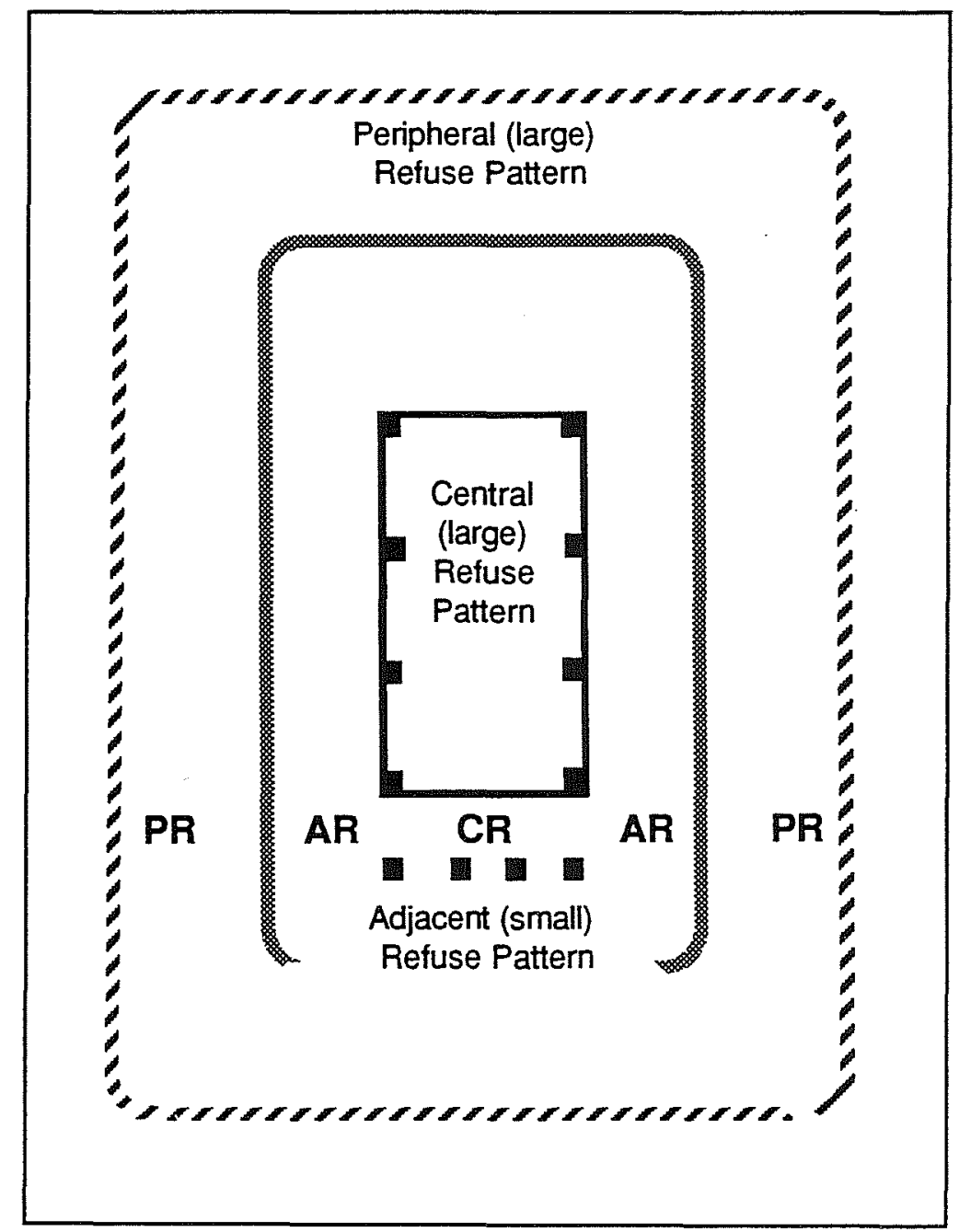

Figure 2-1. Peripheral refuse patterns (South 1979:219). $\mathrm{PR}=$ peripheral region; $\mathrm{AR}=$ adjacent region; $\mathrm{CR}=$ central region. 
Another study on the use of space by Alice Portnoy (1981) defines several different models for spatial patterning of activity areas across a site. The models are based on definitions developed by Goffman (1959) in which the concept of "front regions" and "back regions" are used to explain clustering of activities and spatial behavior. In Goffman's model, people are seen as actors presenting themselves to other individuals who constitute an audience. The performances take place in specified areas: front regions are likened to the stage, where the audience views the performance; back regions are likened to the backstage area where the performances are prepared. Goffman designates certain parts of the contemporary home compound as front and back regions. Back regions include bedrooms, bathrooms (or privies), kitchens, outbuildings, and back external areas. Front regions include all areas where performances are given to people outside the family (living room, dining room, front porch, front yard, etc.).

Portnoy (1981) further divides Goffman's model into "communal" or public activity areas, and "family" or private activity areas. She then applies this activity zone analysis to several different types of cultural arrangements including the !Kung Bushman "ring" model (Figure 2-2) as described by Yellen (1977), the Maya "plaza" type settlement (Figure 2-3), and the "double linear" arrangement (Figure 2-4) similar to that displayed in many contemporary United States communities (Portnoy 1981).

The double linear arrangement appears to be an applicable model for interpreting the neighborhood investigated within the Alamodome development area. Although Portnoy makes no statements regarding the density of artifacts expected from activities carried out within the distinct zones, she suggests the range and kinds of activities conducted within the different zones. This would in turn have an effect on the kinds of artifacts to be deposited within a certain region, and on the expected density of artifacts within a specific region. South's (1979) model bears certain similarities to Portnoy's models; however, South includes comments relating to artifact type and density within his zones. $\mathrm{He}$ states that fewer artifacts tend to be deposited toward the front of a house (which would be Portnoy's "family and communal front region").

Randall Moir (1987a), in examining the use of space around Texas farmsteads, uses the term "yard proxemics" to interpret the patterning over time of the yardscape around a typical dwelling. He points out the primary differences between the traditional yard of 1830-1920 and the yard of today. Before the advent of most modern utilities and services, the yard was the center of much daily activity. This was true of dwellings located in early San Antonio, as well as those located in more rural contexts. In many ways the area around the Alamodome development site in 1850 had more in common with a rural settlement than with an urban area. The main difference was that the average living space on a San Antonio lot within the Alamodome development area was only about onethird the size of the living area of a typical Texas farmstead as described by Moir (1987a). All activities were carried out within a smaller unit of space in the case of the residents of the Alamodome area. The traditional yard of 1850-1920 represented a natural extension of the primary living space. With the development of modern conveniences such as

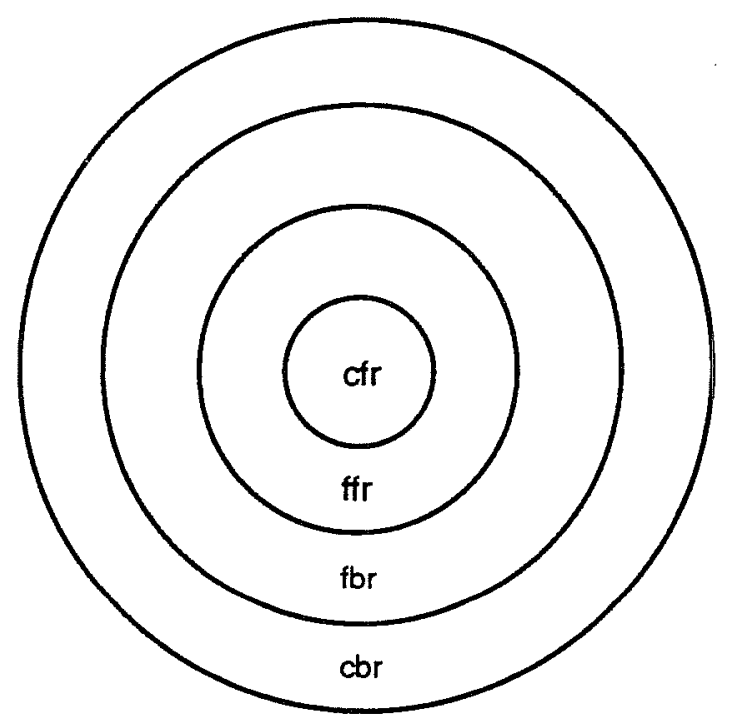

Figure 2-2. General model for a circular settlement (Portnoy 1981:221). cfr =communal front region: ceremonial; $\mathrm{ffr}=$ family front region: social; $\mathrm{fbr}=$ family back region: private; $\mathrm{cbr}=$ communal back region: necessary. 


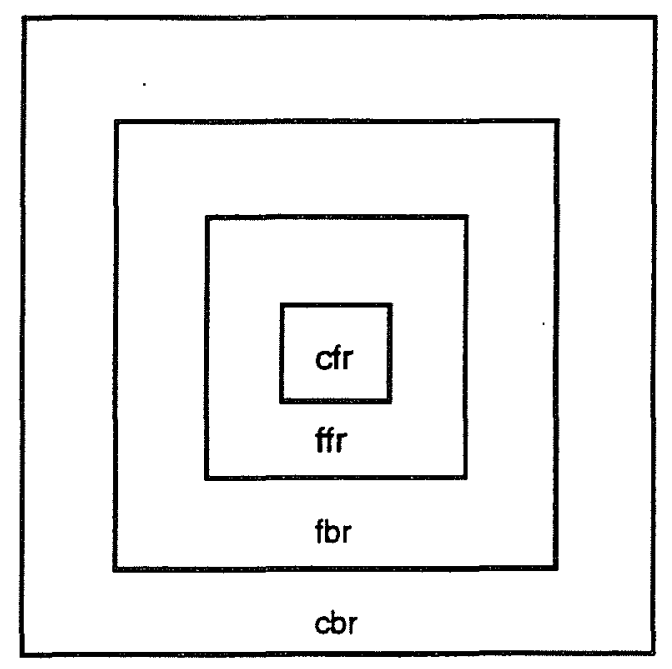

Figure 2-3. General model for plaza settlement (Portnoy 1981:221). cfr =communal front region: ceremonial; $\mathrm{ffr}=$ family front region: social; $\mathrm{fbr}=$ family back region: private; $\mathrm{cbr}=\mathrm{communal}$ back region: necessary.

Figure 2-4. Example of a repeated double linear settlement, U.S. urban (Portnoy 1981:223). $\mathrm{cfr}=$ communal front region: ceremonial; $\mathrm{ffr}=$ family front region: social; $\mathrm{fbr}=$ family back region: private; $\mathrm{cbr}=$ communal back region: necessary.

\begin{tabular}{|c|c|}
\hline $\mathrm{cbr}$ & alley or open space \\
\hline $\mathrm{fbr}$ & back yard \\
\hline $\mathrm{ffr}$ & front vard \\
\hline cfr & sidewalk/street \\
\hline $\mathrm{ffr}$ & front yard \\
\hline $\mathrm{fbr}$ & back vard \\
\hline $\mathrm{cbr}$ & alley or open space \\
\hline $\mathrm{fbr}$ & back yard \\
\hline $\mathrm{ffr}$ & frontvard \\
\hline cfr & sidewalk/street \\
\hline
\end{tabular}

electricity, plumbing, and air conditioning, the traditional yard was replaced by a more ornamental and recreational yard as domestic activities formerly conducted outside became more centralized within the dwelling (Moir 1987a).

In describing artifact deposition across the yards of Texas farmsteads, Moir developed a model having two major components: the immediate active yard and the outer active yard. The former centers on the primary dwelling and extends outward to a radius of $6 \mathrm{~m}( \pm 3 \mathrm{~m})$. Its primary constituent is a moderate- to low-sheet- refuse deposit (40-60 items per square meter). The area shows evidence of having been periodically swept and maintained to remove refuse and burnable materials (Moir 1987a).

The outer active yard extends from the outside edge of the immediate active yard from 6-18 $\mathrm{m}( \pm 3 \mathrm{~m})$ from the central dwelling. This section of the yard contains a higher density of artifacts and the major support structures: storage sheds, smokehouse, and privies. Moir comments that two particular features-wells and privies-often serve as intrasite boundary markers for 
the different yard zones. Wells were often located close to the central structure and divided the immediate active yard from the outer active yard. Privies, on the other hand, tended to be placed along the outside edge of the outer active yard (Moir 1987a).

Binford (1978) describes similar artifact deposit zones at Eskimo hunting camps. He defines a "drop zone" where certain small artifacts are allowed to fall and remain in place, and a "toss zone" where certain larger artifacts are deposited away from the centers of activity. Indeed a marked similarity is seen between the different activity zones as described by South (1979), Moir (1987a), and Binford (1978). The major difference is in the terminology used for the various zones (Table 2-1).

Yellen's (1977) definition of the ring model of !Kung Bushman settlement is also similar to the previously described activity zones. In this case it is a central "communal area," surrounded by a "nuclear area," in turn surrounded by a "special activity area." It should be noted that Yellen's model refers to the activity zones associated with an entire group of people and multiple families rather than a single-family unit. Yellen does mention that each individual nuclear unit within the larger group contains its own hut, hearth, and surrounding debris with a buffer space between different nuclear units (Yellen 1977). So it is very possible that within the !Kung ring model we are viewing a macroscopic version of smaller processes carried out within individual nuclear units.

One other important circumstance likely to affect many of the lots in the Alamodome construction area was that a significant number of the lots had been vacant for a period of time. Nine of the 36 recorded sites at Alamodome were vacant lots at the time of the study.
This figure does not include lots in which the dwelling was removed after the area in general was abandoned. Numerous other lots were likely to have been affected by the presence of large areas of unoccupied space, or by being adjacent to a "non-formal" alleyway running through their area.

Wilk and Schiffer (1979) discuss site formation processes observed on vacant lots in the Tucson, Arizona, area. Seven major activities occur frequently on the vacant lots, significantly affecting their archaeological context.

1) Travel. Vacant lots are often used as "shortcut" routes for travel which departs from the formal grid laid out by urban planners. These trails and the space adjacent to them develop what the authors term "in-transit" refuse (wrappers, containers, cigarette butts, etc.). A distinction is made between paths which cross a lot and those that terminate on a lot: in-transit refuse does not occur on the latter.

2) Refuse disposal. This activity often takes place along and at the ends of trails which terminate on a lot. The types of material discarded consist of refuse not readily collected by the city in its regular pick-ups (vegetal matter from yard maintenance, bulky waste products from demolition or construction). Two of the primary factors listed as driving the decision to dispose of refuse on a vacant lot as opposed to a more formal method (trash collection, landfill) is the rate of refuse production and the nature of the refuse.

3) Storage-abandonment. In many cases items are placed on vacant lots as convenient storage areas

Table 2-1. Artifact Distribution Zones

$\begin{array}{cccc}\text { South (1979) } & \text { Binford (1978) } & \text { Moir (1987a) } & \text { Yellen (1977) } \\ \text { Central Refuse Pattern } & \text { Active Hearth } & \text { Dwelling } & \text { Communal Area } \\ \text { Adjacent Refuse Pattern } & \text { Drop Zone } & \text { Inner Active Yard } & \text { Inner ring (Nuclear Areas) } \\ \text { Peripheral Refuse Pattern } & \text { Toss Zone } & \text { Outer Active Yard } & \begin{array}{c}\text { Outer Ring } \\ \text { (Special Activity Area) }\end{array}\end{array}$


for bulky materials used at an infrequent rate (bricks, lumber, sand, etc.). If not used, this material may end up as part of the archaeological record. Scavenging of stored or abandoned material also affects these deposits.

4) Automobile-related uses. Vacant lots are often used for parking, repair, and dumping of automobile parts. Storage-abandonment processes also apply to automobiles.

5) Child play. Vacant lots are often used by children as play areas. Tree houses, play forts, hearths, and other features are common occurrences on these lots. Messy or destructive behavior not permitted in the home is often practiced on vacant lots.

6) Adult play. Adults also use vacant lots for private or illegal "play." Liquor bottles, spent cartridges, and drug paraphernalia are all common refuse demonstrating the behavior practiced by adults on vacant lots.

7) Camping. Vacant lots are often used as sleeping areas or ad-hoc campsites for vagrants.

The authors identify several factors which apparently influence the patterning of artifact deposition across the lots (Wilk and Schiffer 1979). Looking specifically at travel on and across the lots, they note that the nature of the soil affects the preservation and the displacement of artifacts around a trail. Soft or muddy soil tends to preserve artifacts and allows them to sink into the trail itself. Hard soil tends to displace artifacts off to the side of the trail and to promote breakage, crushing, and fragmentation. Vegetation often contains refuse, some of which is intentionally deposited. Light items tend to be carried by the wind and trapped by the vegetation. Once trapped the items are sheltered by the vegetation, helping to preserve them. Artifacts also accumulate in "fringe areas" located where foot traffic is infrequent.

The accumulation of trash in fringe areas and the "vegetation as artifact trap" phenomenon appear to operate not just on vacant lots but also in the peripheral areas of occupied lots. What is identified as South's (1979) "peripheral refuse pattern" is probably driven by many of the same factors operating on Wilk and
Schiffer's (1979) vacant lots. Many of the activity zones described in Wilk and Schiffer (1979) were present in the Alamodome Project area, and are discussed in the Artifact Group Distribution and Artifact Frequency Analysis sections of this paper.

Based on the presented models, several hypotheses regarding the activity zones expected to be encountered within the Alamodome Project area were advanced.

1) The largest concentrations of artifacts would be found toward the backs of the lots, near the lot margins, close to fence lines, etc.

2) Supporting structures to the primary dwelling would also be found in high concentration in these peripheral areas.

3) Areas directly adjacent to the primary dwelling would yield a lower concentration of artifacts.

4) Investigation beneath the floors of pier-andbeam dwellings would yield significant deposits of artifacts.

5) Front parts of the lots would produce fewer artifacts, and would show a greater tendency toward ornamental and recreational pursuits.

Within Phase 1 archival research, Sanborn maps showing the project area back to about 1904 tended to support the hypothesis regarding outbuilding placement, at least for the three periods available (1904, 1911, and 1952). However, archaeological confirmation was required for other time periods, as well as for advancement of the other hypotheses.

South (1977:xiv) states that we can have no science without pattern recognition, and pattern cannot be refined without quantification. Utilizing a methodology which separates artifacts into individual classes (wire nails, window glass, ceramic sherds, buttons, etc.) and more general groups (kitchen, architecture, activity, personal, etc.), South quantified percentages of artifact occurrences within individual sites. He then compared this data with other sites treated in a like manner. Operating under the hypothesis that archaeological sites developing under similar cultural systems would display patterned regularities within their artifact assemblages, South excavated a series of sites related 
to early British Colonial occupations along the East Coast. Through these excavations and utilization of the described methodology, South discerned several different patterns of occupational artifact deposit.

The "Brunswick pattern of refuse disposal" (South 1977:47-50) shows high levels of artifact deposits centered around entrance areas of early structures. The "Carolina pattern of artifact relationships" (South 1977: 83-88) is a statement of the relational frequencies of artifact groups recovered from secondary refuse around a structure. A high kitchen group in relation to architecture group is the characteristic in this model. The "frontier pattern," which is characterized by a high architecture-to-kitchen artifact ratio, is mostly observed in eighteenth-century frontier military and trading posts, but is also seen inside ruins of domestic function not located on the frontier and in nondomestic structures. Finally the "mean ceramic date formula" is a tool developed by South based on observations of regular patterns of variation in popularity of ceramics through time. This formula monitors site chronology through ceramic occurrence (South 1977:217-218).

Garrow (1981) proposed the recognition of the "Carolina slave artifact pattern" based on excavations conducted at several slave sites. This pattern is typified by high kitchen to low architecture percentages. Garrow suggested that the array of proportions is significantly different from the Carolina and Frontier patterns, but that the slave pattern and the Carolina pattern could be expected to converge in situations where African-Americans became more assimilated into the dominant Anglo-American culture.

South (1977) states that as archaeologists our first responsibility is pattern recognition. However, the ultimate purpose of pattern recognition should be to further our understanding of the behavior/site formation processes behind the observed pattern. Pattern recognition can help in the development of theories and hypotheses relating to past behavior processes, but the identification of patterns of artifact distribution should not be an end in itself. The utility of any observed pattern is primarily in promoting a better understanding of the behavioral processes which produced the pattern. When like patterns of distribution are observed originating from different contexts, one must ask questions regarding possible similarities in the site formation processes. Future studies will undoubtedly refine artifact pattern descriptions; however, development of standardized pattern descriptions is not the goal behind pattern recognition studies and should not be viewed as such. Other applications of artifact pattern recognition studies have demonstrated the flexibility of what can be done with studies of this sort.

For example, Floyd Mansberger (1987) uses a study of artifact group percentages as an indicator of socioeconomic class. He derived his comparative base artifacts from four different excavations conducted in Illinois. Two of the sites were from upper socioeconomic-class families, two were from lower. Mansberger (1987:24-26) projected six hypotheses relating to the differences between the two groups.

1) Households of upper-socioeconomic class will have lower kitchen artifact percentages reflective of more non-food related spending by these groups.

2) Percentage of architecture group will be lower in sites occupied by lower-socioeconomic families reflective of the ephemeral nature of their structures. Consequently upper-class homes should have higher architecture-group percentages.

3) Furniture group will be higher in upper-class homes, reflecting more money spent on furniture items. This is also reflective of higherquality furniture that is more likely to endure than cheaper furniture expected in lower-class homes.

4) Differences in arms group will not be reflective of socioeconomic variability; however urban sites would be expected to yield lower percentages than rural sites due to greater emphasis on hunting in rural households.

5) Tool-related artifacts would be higher in lowersocioeconomic households reflective of more time spent on manual labor (also possibly reflective of a manual occupation). 
6) Clothing and personal groups should be higher in upper-class households reflective of greater amounts of money spent on these items by wealthier groups.

The excavations performed by Mansberger were so similar to those at the Alamodome Project that we decided to address these hypotheses to the Alamodome sites for comparative purposes. Results are given in the Artifact Frequency Analysis section of this volume.

The use of pattern recognition studies provides a good format for the analysis and explanation of cultural processes in motion. Its primary facility at this point is in addressing data from historical sites. However, it is hoped that through this work processes will be explained that operate not only in the historic but in the prehistoric context as well. 


\section{Chapter 3 \\ Methodology}

\section{Project Phases}

The urban nature of the Alamodome Project, subcontractor concerns, a limited time frame, and budgeting elements combined to necessitate the creation of a five-phase project. It is generally understood that elements of any particular phase might be employed to some extent throughout the course of a project. For example, archival research was a continuing endeavor throughout the course of the Alamodome Project, not just within Phase I. The following sections present the methods used during the excavation and mitigation phases.

\section{Methodology}

\section{Excavation Unit Types}

Five major unit types were utilized during the course of the Alamodome Project for sample collection and feature discovery and exposure.

\section{2-x-2-ft Test Unit}

A 2-x-2-ft unit was the most common hand-excavated test utilized during the project. It was most commonly employed during Phase II of the investigations to examine large areas for the presence of archaeological features and deposits. The level of information derived from these test units was generally higher than what could be expected from a simple shovel test (see below). The 2-x-2-ft test units were also employed during Phase IV mitigation when a smaller area of exposure was desired. In most cases, the soil excavated from these test units was run through $1 / 4$-inch mesh screen.

\section{4-x-4-ft Mitigation Unit}

These units were used primarily at 41BX896, mostly within the context of a larger overall excavation block. All the units were oriented north/south, and each 4- $\mathrm{x}-4-\mathrm{ft}$ unit could be subdivided into 2-x-2-ft quadrants if necessary. This type of unit facilitated the exposure of large features such as several of the outbuildings encountered at 41BX896. Excavation was done in five-inch levels and, although individual 2- $\mathrm{x}$-2-ft quadrants may have been taken deeper than 12 inches, most of the 4-x-4-ft units were fairly shallow (0-12 inches).

The 4-x-4-ft block unit was also applied to several other sites excavated during Phase IV of the project; however, the application was as a single unit rather than as a part of an overall larger block (41BX931, 41BX945). Most material taken from these excavations was run through a $1 / 4$-inch mesh screen.

\section{Shovel Tests}

Shovel tests, as applied within the Alamodome Project, were designed to test large areas for quantitative information pertaining to sheet refuse, or to localize activity zones within a certain area. Simple stratigraphic information was also obtained through the use of these tests. The standard shovel test was a circular hole about 15 inches in diameter and running from 12-18 inches deep. Spacing of these units was done in a more controlled fashion than with other standard test units employed. All excavated material was screened through $1 / 4$-inch mesh. 
Shovel tests were designated by north/south and east/west coordinates from individual site datums. For example, shovel test N106E142 would be $106 \mathrm{ft}$ north and $142 \mathrm{ft}$ east of the site datum.

\section{Backhoe Trenches}

Backhoe trenches were used for various objectives throughout the project area. The standard size of a backhoe trench was two feet wide and 24-36 inches deep. Length varied greatly from trench to trench.

During Phase II, the primary objective of backhoe testing was to locate features and activity zones within the lots. Backhoe trenches were also used for observation and documentation of stratigraphic changes across the lots under investigation and to facilitate the location and exposure of foundation elements of buried structures around the project area. Little soil was screened during these operations; however, all soil was put through a monitoring process. The process involved close examination of the soil by one or more individuals who dispersed the excavated soil in such a fashion as to detect any cultural material.

During Phase IV, tighter control was implemented over the excavation of backhoe trenches. All trenches excavated were divided into $10-\mathrm{ft}$ subsections. Each $10-\mathrm{ft}$ section was regarded as a single unit. Collection of artifacts within each section was done by scoops (the project was fortunate enough to have had a single backhoe operator over the whole course of the project who had a high degree of skill in maintaining depth control, even with such a large piece of machinery):

1) Scoop 1 (0-5 inches) - all soil was monitored and placed within designated bags;

2) Scoop 2 (5-10 inches) - all soil was screened through a 1/4-inch mesh and artifacts bagged separately;

3) Scoop 3+ (10 inches and deeper) - all soil was monitored and artifacts bagged separately.

This methodology allowed us to quantify materials derived from the excavation of each backhoe trench.
Geomorphic Trenches

These trenches were designed to observe the stratigraphic context of the Alamodome Project area. In general they were much shorter than the standard backhoe trenches employed, however they were carried to a much greater depth. For details regarding geomorphological work performed during the project, see Appendix C.

\section{Recording and Curation}

Unit/level or feature forms were completed for all excavation unit types. Plan maps and profiles were drawn. Black-and-white prints and color slides were taken of all sites and representative excavation units and features. All field logs and forms, photographs, and illustrations are on file at the CAR laboratory.

Recovered artifacts were bagged by provenience and transported to the CAR laboratory for processing. All artifacts were washed, air-dried, labeled, sorted, catalogued, and analyzed by type. All artifacts are curated at the CAR laboratory.

\section{Sanborn Maps as Archival Tools}

One of the most common reference tools used during the course of the Alamodome Project was the Sanborn fire insurance map. The Sanborn Company-which is a division of Real Estate Data Inc. in Pelham, New York-has been publishing maps since 1866. The original purpose of the maps was to address the needs of the fire-insurance industry. With the development of better fire-fighting equipment, telephones, automobiles, and the implementation of building codes, much of the need for such maps was eliminated.

For larger cities the Sanborn Company would update its maps every two to three years, and for smaller communities every seven to 10 years. In many cases the updates would not involve the generation of a totally new map. The old map would be updated by pasting new sections over the outdated areas. Since the fire insurance industry no longer needs Sanborn maps, the company has regeared its operations to address other interests such as real estate, urban planning, and 
historical research. As a result, only a handful of United States cities continue to be updated with new maps.

The earliest Sanborn maps for San Antonio date to 1877 and cover only the area around the central plazas. As for the area investigated during the Alamodome Project, maps were available for the area around the Southern Pacific Railroad station (New City Block [NCB] 679) dating back to 1883; however, maps were not available for the whole area in general until 1904. Three sets of Sanborn maps were available to the project for use during the course of investigations. The dates of production were 1904, 1911 , and 1952.

Using these maps as reference material for archaeological investigations presented several obvious limitations, as well as posing several intriguing questions. How accurate are the maps as to the reality of the situation at the time they were drawn? Are the measurements and scales correct? Are the available maps originals or pasted-up versions? If the latter is true, then they could conceivably be representing a time period significantly later than the time given as the production date on the map.

Even if the maps are accurate, they are still static representations of three moments in time over a period of about 50 years. Other archival sources indicate the project area had been occupied since the early 1850 s and that the area experienced a population boom after 1877 when the railroad was built through the area. A massive amount of change could have and probably did occur during the "blank spots" not covered by the maps.

Although the maps in some cases made reference to the material used in the construction of a building and to its function, this was by no means consistent. No information pertaining to the age of structures was present other than the date of the map itself. Another form of ambiguity existed in the width of the roads as depicted on the maps. The roads in actuality varied in width, and accurate measurements could not be taken using the edge of the road as a marker. The best place from which to measure on the map was usually the front of a house.
Fortunately the project had deed records, builders' liens, city directories, and many other supplementary sources available to fill some of the gaps left by the Sanborn maps. However, with such a large-scale project we were presented with an ideal opportunity to test the maps for their applicability to the archaeological profession. How much did they show and how accurate was the detail of what they did show?

Closely tied to these questions, of course, was the question of the state of preservation of any ruins that might be encountered from certain structures indicated as being present on one or more of the Sanborn maps. Could we as archaeologists verify a particular structure with a high degree of certainty as being a structure pictured on a Sanborn map? What about earlier or later structures that may have occupied the same relative location?

These questions were asked throughout the course of the excavations. A comparison of the information on the Sanborn maps with what was found archaeologically is provided in the concluding chapter. 


\section{Chapter 4 The Sites}

\section{Introduction}

In the course of the Alamodome Project, 36 archaeological sites-encompassing 409,116 total square feet-were identified and studied. Table 4-1 gives the site dimensions and Figure 4-1 the locations.
As discussed in the previous section, five major unit types were utilized during the Alamodome Project. Table 4-2 presents the work performed on each of the 36 sites. The English measurement system was used for consistency with other urban archaeology projects and with construction of the structures.

Table 4-1. Alamodome Project Site Sizes

\begin{tabular}{cccccc}
\hline Site \# & Site Area & Square Footage & Site \# & Site Area & Square Footage \\
$41 \mathrm{BX} 881$ & $49.1 \times 189$ & 9280 & $41 \mathrm{BX} 928$ & $56 \times 82.5$ & 4620 \\
$41 \mathrm{BX} 882$ & $48.7 \times 63$ & 3068 & $41 \mathrm{BX} 929$ & $55.6 \times 172.2$ & 9574 \\
$41 \mathrm{BX} 883$ & $63 \times 210$ & 13230 & $41 \mathrm{BX} 930$ & $48.9 \times 94.5$ & 4621 \\
$41 \mathrm{BX} 884$ & $51 \times 110$ & 5610 & $41 \mathrm{BX} 931$ & $34.2 \times 60$ & 2052 \\
$41 \mathrm{BX} 885$ & $62 \times 88$ & 5456 & $41 \mathrm{BX} 932$ & $40 \times 60$ & 2400 \\
$41 \mathrm{BX} 890$ & $42 \times 200$ & 8400 & $41 \mathrm{BX} 936$ & $40 \times 120$ & 4800 \\
$41 \mathrm{BX} 891$ & $70 \times 200$ & 14000 & $41 \mathrm{BX} 937$ & $84 \times 150$ & 12600 \\
$41 \mathrm{BX} 892$ & $52 \times 180$ & 9360 & $41 \mathrm{BX} 938$ & $56.2 \times 180$ & 10116 \\
$41 \mathrm{BX} 893$ & $68 \times 200$ & 13600 & $41 \mathrm{BX} 939$ & $41 \times 62$ & 2542 \\
$41 \mathrm{BX} 894$ & $65 \times 200$ & 13000 & $41 \mathrm{BX} 940$ & $18 \times 50$ & 900 \\
$41 \mathrm{BX} 895$ & $70 \times 110$ & 7700 & $41 \mathrm{BX} 941$ & $41 \times 60$ & 2460 \\
$41 \mathrm{BX} 896$ & $111.2 \times 154.2$ & 17147 & $41 \mathrm{BX} 942$ & $41 \times 60$ & 2460 \\
$41 \mathrm{BX} 897$ & $70 \times 200$ & 14000 & $41 \mathrm{BX} 943$ & $30 \times 60$ & 1800 \\
$41 \mathrm{BXX} 898$ & $60 \times 209.5$ & 12570 & $41 \mathrm{BX} 944$ & $43 \times 60$ & 2580 \\
$41 \mathrm{BX} 899$ & $74 \times 209.5$ & 15503 & $41 \mathrm{BX} 945$ & $126.4 \times 200$ & 25280 \\
$41 \mathrm{BX} 900$ & $76 \times 180$ & 13680 & $41 \mathrm{BX} 955$ & $50 \times 200$ & 10000 \\
$41 \mathrm{BX} 926$ & $50 \times 63$ & 3150 & $41 \mathrm{BX} 956$ & $180 \times 250$ & 45000 \\
$41 \mathrm{~B} 9927$ & $152.3 \times 207.2$ & 31557 & $41 \mathrm{BX} 957$ & $220 \times 250$ & 55000 \\
& & & & & \\
\hline
\end{tabular}




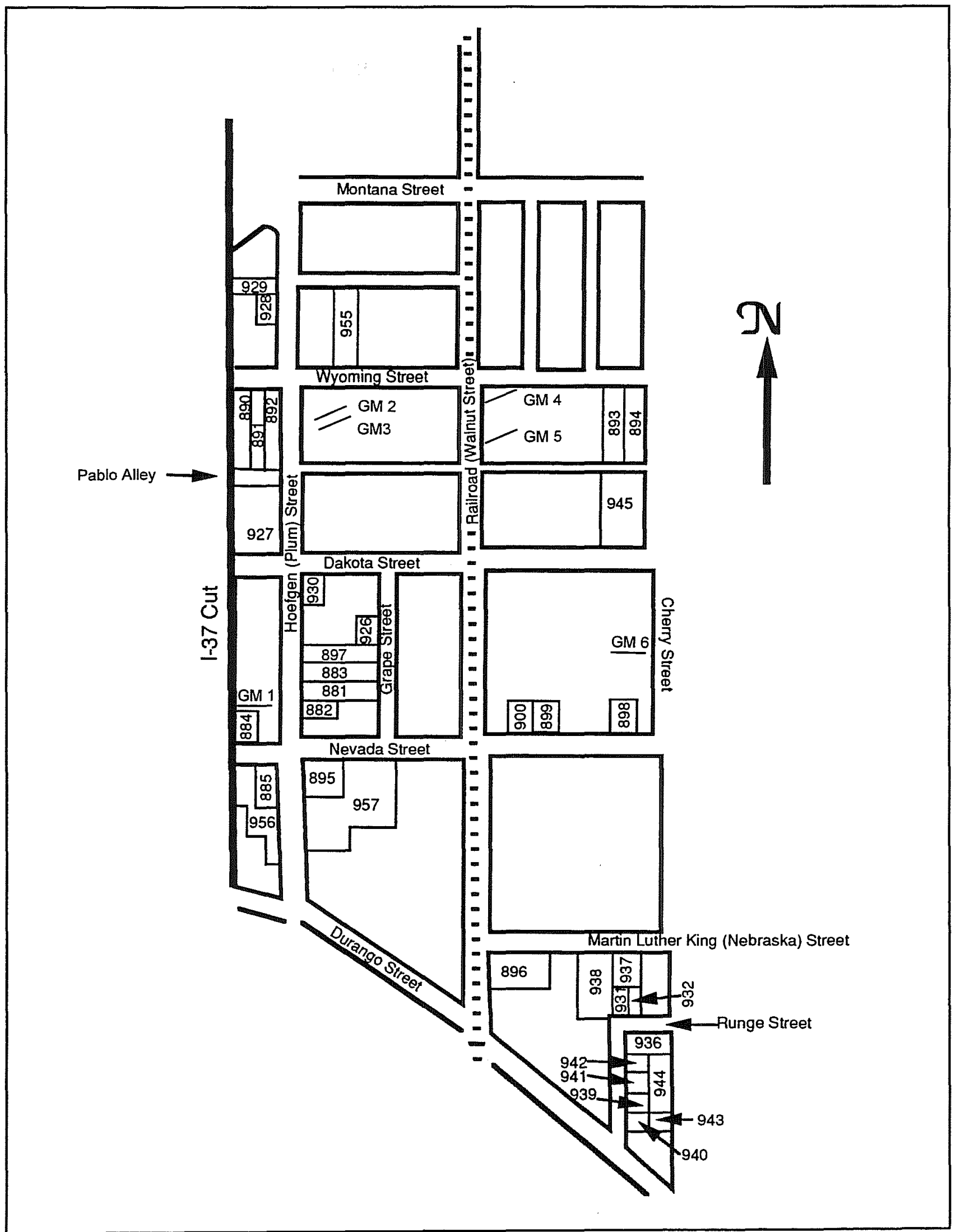

Figure 4-1. Alamodome Project site and geomorphic trench (GM) locations. The numbers are the last three digits of the site trinomials beginning 41BX. 
Table 4-2. Alamodome Project, Work Performed on Sites

\begin{tabular}{|c|c|c|c|c|c|c|c|c|}
\hline Site Name & Period & Site \# & NCB & Lot \# & Address & Survey & Test & Excavation \\
\hline Oeffinger & late $1880 s$ & $41 \mathrm{~B} \times 881$ & 621 & $\mathrm{A11}$ & $123 \mathrm{Grapo}$ & Yes & Yes & $\mathrm{No}$ \\
\hline Haas & ca. 1900 & $41 \mathrm{BX} 882$ & 621 & $11(\mathrm{~N})$ & 326 Hoefgen & Yes & Yes & No \\
\hline CKng & ate $1880 \mathrm{~s}$ & $41 \mathrm{~B} \times 883$ & 621 & \%? & 320 Hoefuen & Yes & Yes & $\mathrm{No}$ \\
\hline Griesenbeck & ca. 1889 & $41 \mathrm{~B} \times 884$ & 620 & $12(S)$ & 123 Nevada & Yes & Yes & No \\
\hline Menditshop & late $1800 \mathrm{~s}$ & $41 \mathrm{~B} \times 885$ & 627 & १? & 409 Hoefgen & Yes & Yes & $\mathrm{No}$ \\
\hline Biesenbach & late $1850 \mathrm{~s}$ & $41 \mathrm{~B} \times 890$ & 613 & 4 & 122 Wyoming & Yes & Yes & No \\
\hline Horn & late $1850 \mathrm{~s}$ & $41 \mathrm{~B} \times 891$ & 613 & 5 & 128 Woming & Yes & Yes & $\mathrm{No}$ \\
\hline Rilling & late $1850 \mathrm{~s}$ & $41 B \times 892$ & 613 & 6 & 132 Wyoming & Yes & Yes & No \\
\hline ezernek & ca 1890 & $4 \mathrm{BX893}$ & 615 & 7 & 124 woming & Yes & Yes & $\mathrm{No}$ \\
\hline Czernecki Rentals & post 1905 & $41 \mathrm{~B} \times 894$ & 615 & 8 & $401-415$ Cherry & Yes & Yes & No \\
\hline Garzastore & op 1888 & $41 \mathrm{BX} 895$ & 628 & 182 & 6021 oefgen & Yes & Yes & $\mathrm{No}$ \\
\hline Demazieres & mid $1850 \mathrm{~s}$ & $41 \mathrm{~B} \times 896$ & 636 & $4 \& 5$ & 102 M. L. King & Yes & Yes & Yes \\
\hline webo & $\mathrm{ca} 1866$ & $41 \mathrm{BX} 897$ & 621 & 1 & 514516 Hoefgen & Yes & Yes & Yes \\
\hline E. Glaeser & mid $1850 \mathrm{~s}$ & $41 \mathrm{BX} 898$ & 622 & $9 \& 10$ & 325 Nevada & Yes & Yes & Protected \\
\hline 6 Glaeser & mid $1850 s$ & $41 \mathrm{~B} \times 899$ & 622 & 18 \% & 313 Nevada & yes & $\mathrm{xes}$ & Protected \\
\hline Gordon & late $1850 \mathrm{~s}$ & $41 \mathrm{~B} \times 900$ & 622 & 7 & 305 Nevada & Yes & Yes & No \\
\hline Doenth & late 18500 & $41 B \times 926$ & 621 & 6 & 214 Oakofa & No & $\mathrm{Yes}$ & $\mathrm{No}$ \\
\hline Schulze & ca. $1860 \mathrm{~s}$ & $41 \mathrm{BX} 927$ & 613 & 10 & 233 Hoefgen & No & Yes & No \\
\hline Eckenroth & ca $1880 \mathrm{~s}$ & $41 \mathrm{BX} 928$ & 605 & 1 & 319 1oefgen & $\mathrm{No}$ & Yes & No \\
\hline Umschied & ca. $1890 \mathrm{~s}$ & $41 B \times 929$ & 605 & 6 & 306 Santa Clara & No & Yes & No \\
\hline Res well & ca $1890 \mathrm{~s}$ & $41 \mathrm{~B} \times 930$ & 621 & $1 \& 2$ & $502 \mathrm{Hoefgen}$ & $\mathrm{No}$ & $\mathrm{Yes}$ & $\mathrm{No}$ \\
\hline Petit & ca. $1920 \mathrm{~s}$ & $41 \mathrm{BX} 931$ & 636 & D & 125 Runge & Yes & Yes & No \\
\hline Thomas House & ca.1920s & $41 \mathrm{~B} \times 932$ & 636 & @ & 127 Runge & Yes & Yes & $\mathrm{No}$ \\
\hline Burleson & ca. $1920 \mathrm{~s}$ & $41 \mathrm{~B} \times 936$ & 636 & $\mathrm{H} \& \mathrm{I}$ & 719 Cherry & Yes & Yes & No \\
\hline Gibert & ca. $1880 s$ & $41 \mathrm{~B} \times 937$ & 636 & 18 & $124 \mathrm{M} \mathrm{L} \mathrm{K} n \mathrm{~g}$ & Yes & Yes & $\mathrm{No}$ \\
\hline Conrad & ca. $1880 \mathrm{~s}$ & $41 \mathrm{BX} 938$ & 636 & 7 & 122 M. L. King & Yes & Yes & No \\
\hline Jones & ca $1920 s$ & $41 \mathrm{~B} \times 939$ & 636 & $\mathrm{~N}$ & 114 Runge & Yes & $\mathrm{Yes}$ & $\mathrm{No}$ \\
\hline Meeks & ca. $1920 \mathrm{~s}$ & $41 \mathrm{BX} 940$ & 636 & $\mathrm{P}$ & 112 Runge & Yes & Yes & No \\
\hline Houstot & ca $1920 \mathrm{~s}$ & $41 \mathrm{~B} \times 94 \mathrm{O}$ & 636 & 1 & 116 Runge & yes & Xes & $\mathrm{No}$ \\
\hline Harris & ca. $1920 \mathrm{~s}$ & $41 \mathrm{BX} 942$ & 636 & $\mathrm{~J}$ & 118 Runge & Yes & Yes & No \\
\hline orant & ca, $1920 \mathrm{~s}$ & $41 \mathrm{~B} \times 943$ & 636 & 8 & 131 ohery & Yes & Yes & $\mathrm{No}$ \\
\hline Runge Rental & ca. $1920 \mathrm{~s}$ & $41 \mathrm{BX} 944$ & 636 & $\mathrm{~K}, \mathrm{M}, \mathrm{O}$ & $721-727$ Cherry & Yes & Yes & No \\
\hline Pauly House & early $1850 \mathrm{~s}$ & $11 \mathrm{~B} \times 94$ & 615 & 15816 & 325 Pakota & $\mathrm{xes}$ & Yes & Yes \\
\hline Erecting Shop & ca. $1870 \mathrm{~s}$ & $41 \mathrm{~B} \times 955$ & 606 & 11 & 609 Wyoming & No & Yes & No \\
\hline W Hoergen/S Nevgda & ca $1880 \mathrm{~s}-1800 \mathrm{~s}$ & $41 \mathrm{~B} \times 956$ & 627 & 1 & 607619 Hoefgen & 10 & No & No \\
\hline E. Hoefgen/S. Nevada & ca. $1880 \mathrm{~s}-1890 \mathrm{~s}$ & $41 \mathrm{BX} 957$ & 628 & - & $\begin{array}{l}610-618 \text { Hoefgen } \\
208-214 \text { Nevada }\end{array}$ & Yes & No & No \\
\hline
\end{tabular}


Throughout this report, artifact counts and percentages are presented. Detailed lists of the content of each artifact group are given in Appendix A. Raw counts by site number and group are given in Appendix B, Table B-1. All glass fragments, nails, bricks, plaster, buttons, etc. were individually counted; hence counts are based on actual total numbers. Artifact group percentages by site number and group are presented in Appendix B, Table B-2. A rank ordering of artifact group percentages of examined sites is given in Appendix B, Table B-3. Quantitative comparisons were only made between excavation units that were the same size and were screened in a like manner. Sites were only selected as part of a sample population if they had produced over 500 artifacts.

\section{BX881 - NCB 621, Lot A11}

From July 10 to July 25,1990 , test excavations were conducted at NCB 621, Lot A11, 123 Grape Street (Figures 4-2 and 4-3). This site was later designated 41BX881, the Oeffinger site, named for the first recorded resident of the lot, John Oeffinger, who resided on the property from 1893-1904. Oeffinger's profession was listed as carpenter (Bexar County Deed Records [BCDR], Bexar County Courthouse, San Antonio, Texas, 127:157; City Directories [CD] 1894-1896).The primary reasons behind selecting this site as the first to be tested was that the lot was relatively clear of surface debris, and a structure that was recorded as having been present on the east side of the lot on the 1904 Sanborn Insurance map had been removed (around 1938). At the time archaeological testing started, a more contemporary frame house occupied the west side of Lot A11 fronting on Hoefgen Street, and a small wooden outbuilding positioned against the south property line just behind this structure was vacant.

In addition to the primary dwelling shown on the 1904 Sanborn map, a smaller outbuilding is pictured as having been present in the central portion of the lot. By 1911 this smaller structure had either been added on to or replaced by another structure which, on the 1911 Sanborn map, is designated a dwelling (Figure 4-4).

\section{Excavations (Figure 4-5)}

A datum point (elevation $652.45 \mathrm{ft}$ amsl) was established in the northeast corner of Lot A11 with the baseline running north and west. Fourteen 2-x-2-ft test units were placed from just west of Grape Street to about $80 \mathrm{ft}$ west of Grape Street. Unit placement was designed to investigate the area occupied by the 1893 structure (A) and to provide general coverage of the outside yardscape. Four backhoe trenches were also placed near the central area of Lot A11 to search for possible features and for evidence of the second small structure (C) which the 1911 Sanborn map indicates was located there.

No foundations were discovered for either of the structures. Stratigraphic evidence for Structure A was found in two units positioned toward what would have been the back (west side) of the structure as pictured in the 1904 and 1911 Sanborn maps. One unit, N27W57, showed a very distinctive horizontal break at eight inches depth, running east/west across the unit. The northern half of the unit showed a thick lightcolored caliche soil, while the southern half was composed of a darkish-brown clay soil.

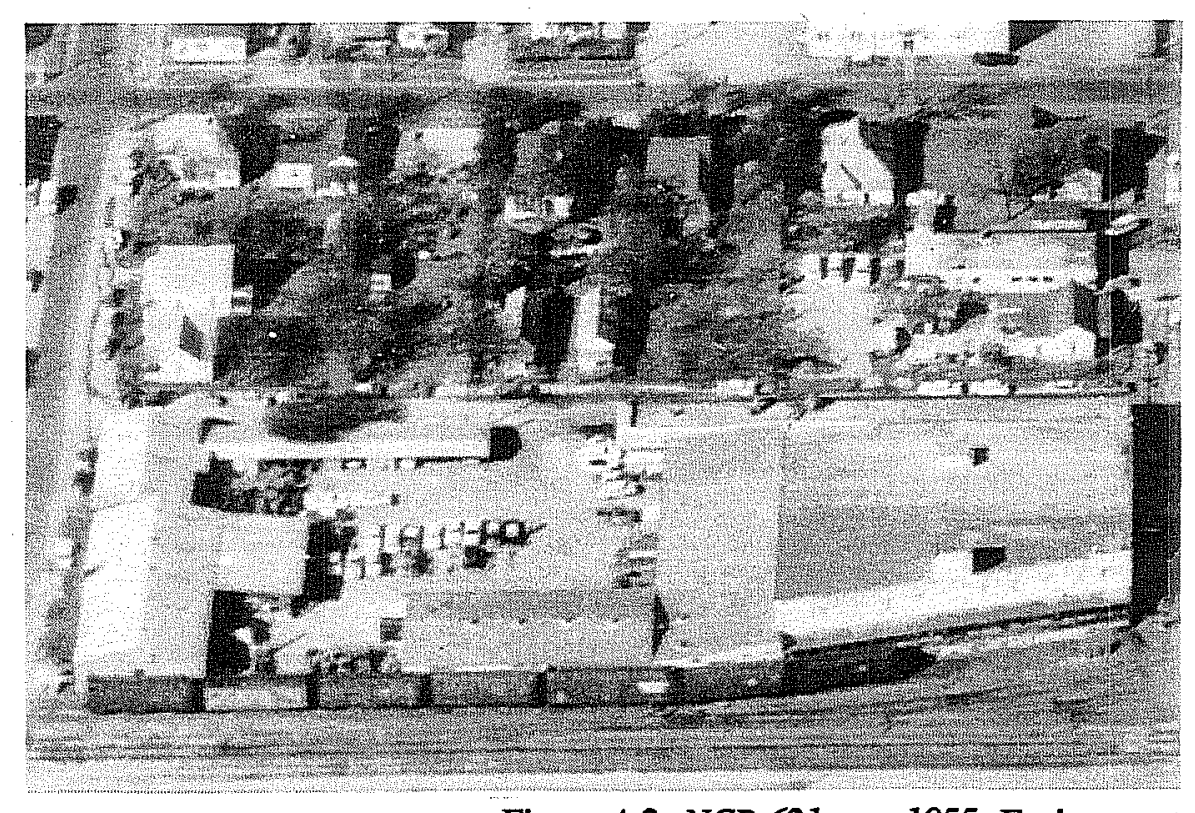

Figure 4-2. NCB 621, ca. 1955. Facing west. 


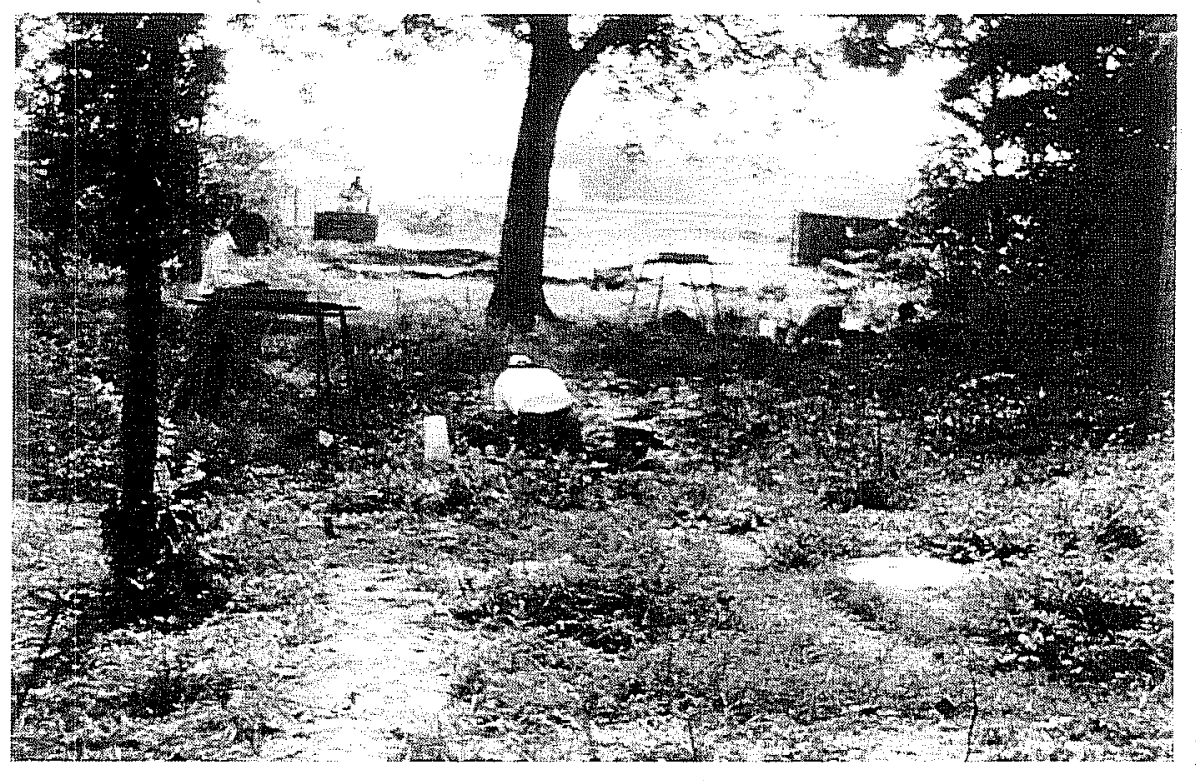

Figure 4-3. The Oeffinger site.

The second unit, N31W55, exhibited the light-colored caliche across the whole unit at eight inches depth. The horizontal break in N27W57 probably represents the edge of a dripline from the outside edge of the house, while the caliche soil represents the underside of the structure. A similar situation was encountered in Backhoe Trench D, placed where Structure $C$ was indicated to have been. It was obvious that significant use had been made of the central and east sides of Lot A11. Layers of ash were present containing many contemporary artifacts from about $45-55 \mathrm{ft}$ west on the site. Also, large amounts of stone and asphalt had been deposited along the northeast boundary of the site. The southeast boundary line was being used as a scrap wood pile at the time excavations started.

\section{Artifact Group Distributions and Comments}

Table 4-3 shows the percentage of occurrence within artifact groups on this site. Figure 4-6 illustrates the spatial frequency of artifacts across the site. The highest occurrence of artifacts as depicted on the graph was the result of a trash disposal/burning feature present on that part of the lot. The graph also shows a higher incidence of artifact occurrence on the north side of the lot. This was the side of the lot which contained the dwelling.

Table 4-3. Site Artifact Frequency Distributions for 41BX881

\begin{tabular}{|c|c|c|c|}
\hline Group & $\#$ & $\%$ & Notes \\
\hline Activity & 174 & 5.66 & 58 chert frags.; 35 wire pieces \\
\hline Architecture & 1,422 & 46.27 & 926 wire nails \\
\hline Arms & 5 & 0.16 & 4 cartridges \\
\hline Bone & 626 & 20.37 & \\
\hline Clothing & 30 & 0.98 & 15 buttons \\
\hline Furniture & 2 & 0.07 & \\
\hline Kitchen & 791 & 25.74 & 604 bottle glass; 169 ceramics \\
\hline Personal & 23 & 0.75 & 9 slate frags. \\
\hline Total: & 3,073 & 100 & \\
\hline
\end{tabular}




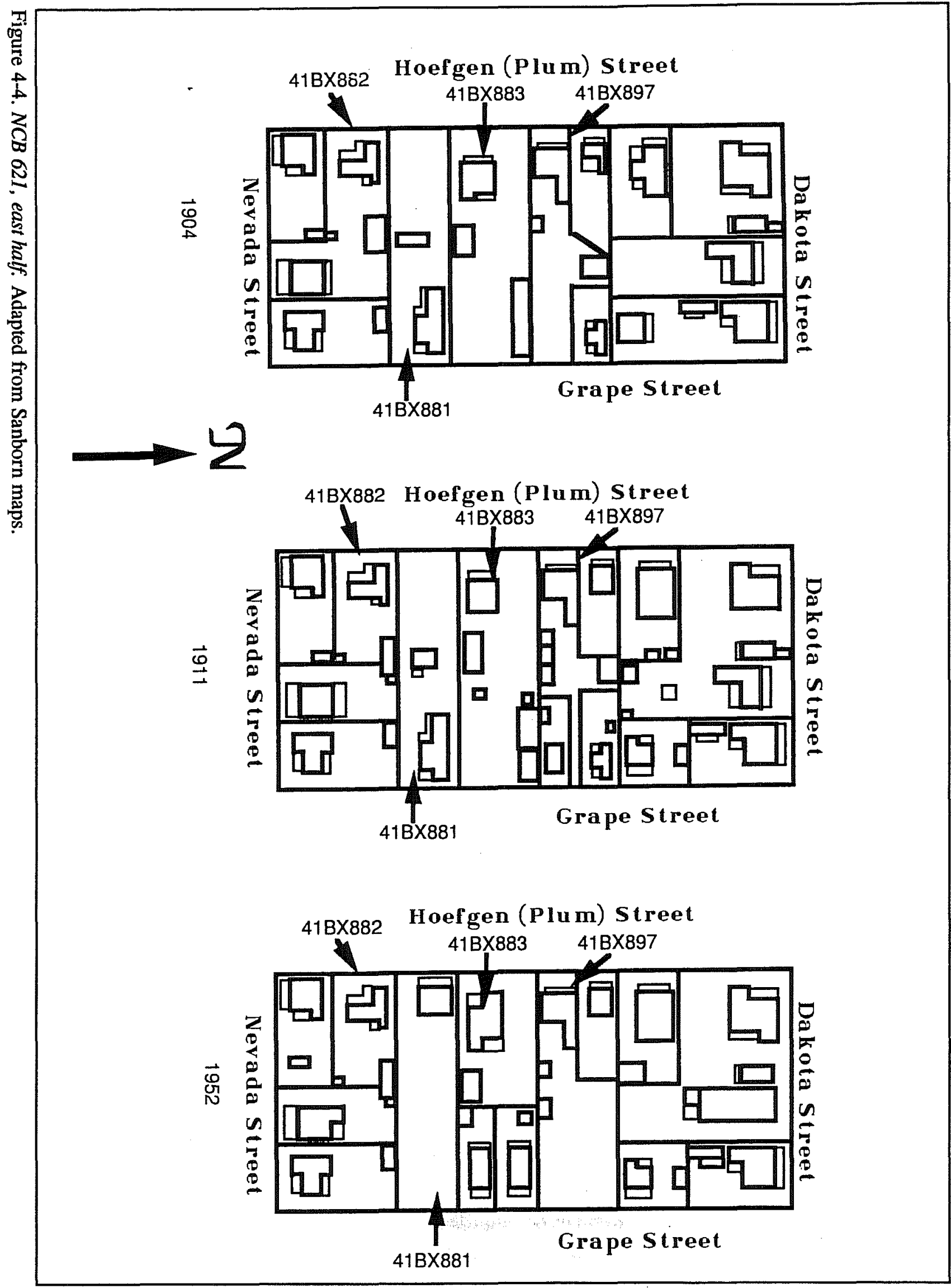




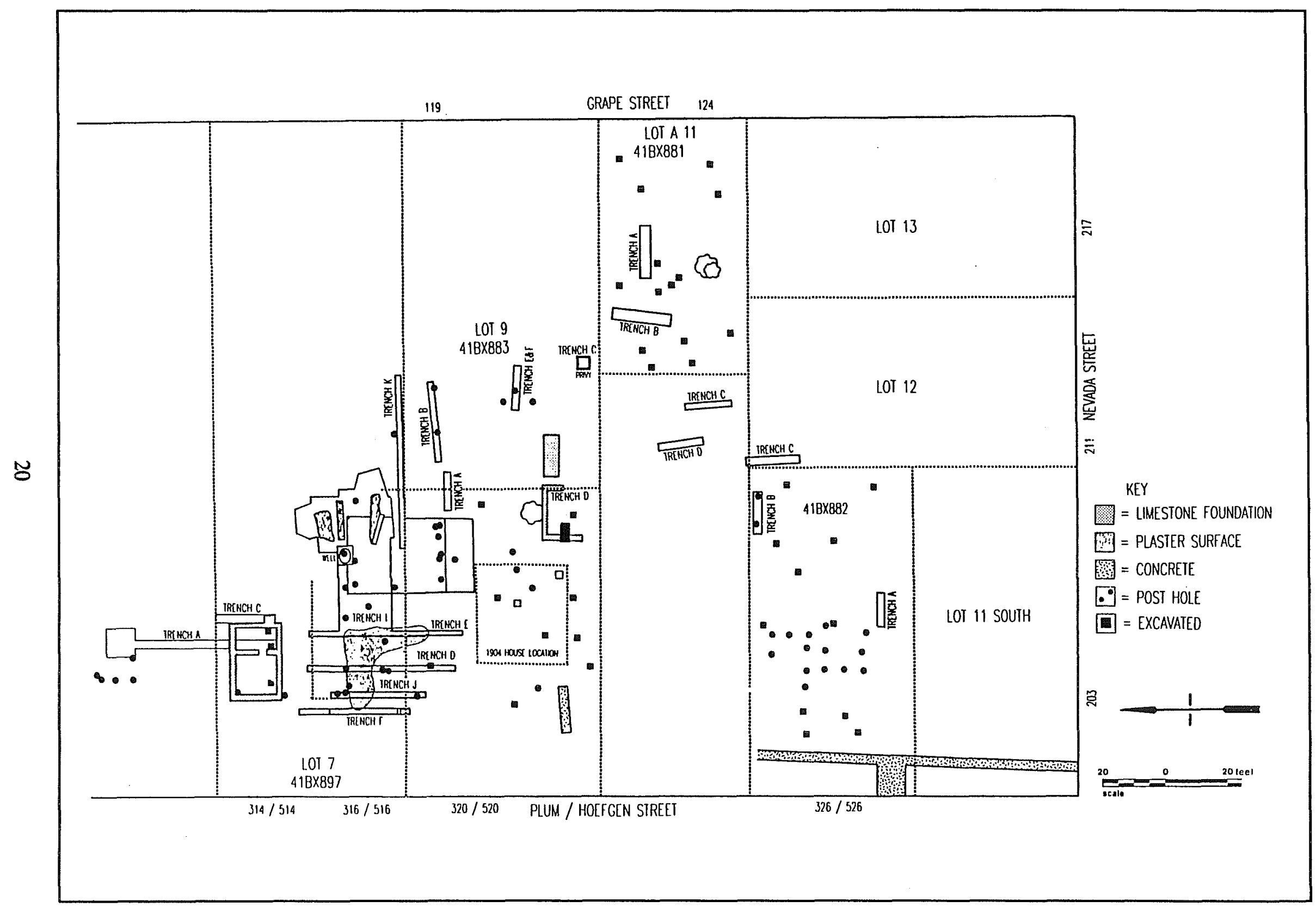

Figure 4-5. NCB 621 east; sites 41BX881, 41BX882, 41BX883, and 41BX897. 


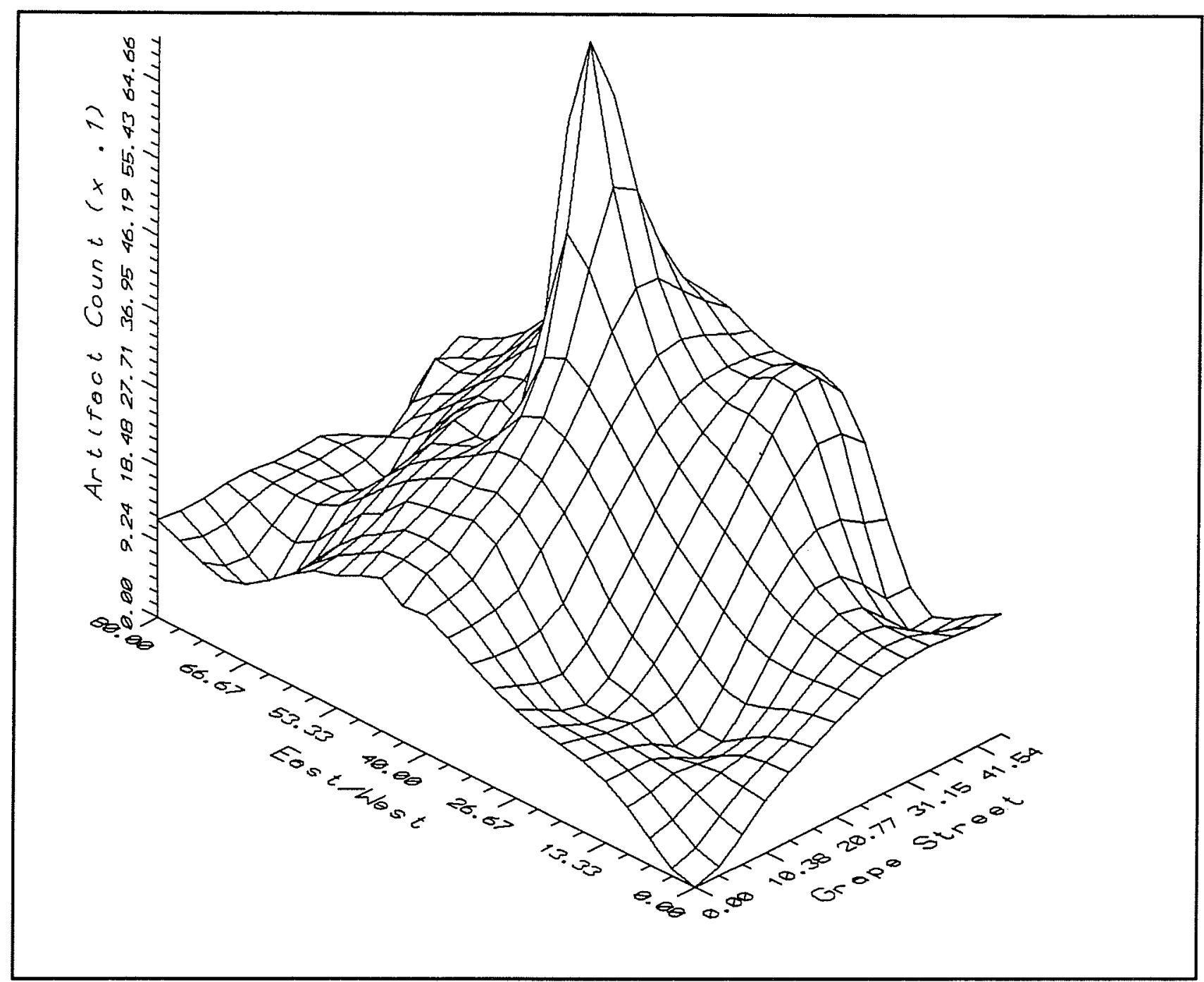

Figure 4-6. 41BX881, spatial frequency of artifacts across the site.

\section{BX882 - NCB 621, Lot 11 (North)}

From July 13 to July 30,1990 , test excavations were carried out at 326 Plum/526 Hoefgen Street, later designated 41BX882, the Haas site (Figure 4-5). At the time excavation started on this lot, no existing structures were present on the surface. However, evidence that a pier-and-beam structure had resided on the west side of the lot fronting onto Hoefgen Street was present in the form of several cedar posts protruding from the ground in this location. By mapping the protruding posts, a fairly accurate assessment could be made of the size and placement of this primary structure (A). This structure is present on all three of the available Sanborn maps (1904, 1911, 1952).
Archival information indicated that the structure was built around 1900 by Julius Haas. The latter acquired this lot and an adjoining one (12) fronting on Nevada Street in 1892 (BCDR 106:335). The Haas family lived in the Nevada Street residence while 326 Plum served as a rental house. The first resident was a Mr. Horning who lived in the home from 1900-1906 (CD 1901-1906). Structure A continued to serve as a rental house throughout its history until being removed from the lot after 1970.

The 1904 Sanborn map shows Lots 11 North and 12 as undivided at that time. A second structure (B) is pictured occupying part of Lot 11 North in the northeast corner. Although no designation as a dwelling is present, the structure does have an address 
(3261/2 Plum) which indicates it was functioning as a residence at that time. By 1911 the Sanborn maps indicate that Lot 11 North and Lot 12 are divided. Structure B is no longer assigned an address, but a building is still present in the same location (Figure 4-4).

\section{Excavations (Figure 4-5)}

A datum point (elevation $651.25 \mathrm{ft}$ amsl) was established in the southwest corner of Lot 11 North, abutting Hoefgen Street, with the baseline running north and east. Fourteen 2-x-2-ft test units were placed from just east of a sidewalk cutting across the west side of the lot to the east end of the lot. The latter area would have been the backyard for Structure A and in the immediate vicinity of Structure B. Unit placement was designed to investigate the area surrounding the location of Structure $A$, to confirm the placement of Structure $B$, and to gain evidence on the possible function of this structure. A third very small structure (5-x-5-ft, privy?) was indicated on the Sanborn maps as being present in the southeast corner of the lot. This area of the site was not investigated during the project due to the presence of large amounts of debris in this location, as well as demolition crews working very close by.

Three backhoe trenches were also placed on the site (Figure 4-5). Trench A (E-W) was designed to investigate the south boundary of the lot where a contemporary driveway was located. Trench B (E-W) was placed in the northeast corner of the lot to investigate the area occupied by Structure $B$. Trench $C$ $(\mathrm{N}-\mathrm{S})$ was located along the northeast boundary of the lot and was also designed to provide information on Structure B.

As previously mentioned, structural evidence associated with Structure A was present on the surface of the lot in the form of cedar posts protruding above the ground surface. Structural evidence for Structure B was found in Trenches B and C. Four cedar posts (three round, sixinch diameter; one four inches square) were found at a depth of approximately 6-8 inches below the surface within the area pictured on the Sanborn map as having been occupied by Structure $B$.

\section{Artifact Group Distributions and Comments}

Table 4-4 shows the artifact percentage distribution from the site. Figure 4-7 illustrates the spatial frequency of artifact occurrence across the site. The northeast corner of the lot shows the heaviest deposits, many of which were associated with structures previously located there. The western half of the site exhibited abandonment patterns that were observed in several different locations throughout the project area. These patterns have several characteristics.

1) If a dwelling had been removed, a depression was located where the dwelling had stood. The appearance of the depression varied according to the type of floor present in the dwelling. If the floor was loose and allowed dirt and debris to fall through, then the depression may not be distinct.

Table 4-4. Site Artifact Frequency Distributions for 41BX882

\begin{tabular}{|c|c|c|c|}
\hline$\overline{\text { Group }}$ & \#\# & $\overline{\overline{\%}}$ & Notes \\
\hline Activity & 324 & 20.04 & 122 wire; 77 other barn items \\
\hline Architecture & 1,175 & 0.06 & 594 wire nails; 195 window glass \\
\hline Arms & 3 & 0.19 & 2 cartridges; 1 gun part \\
\hline Bone & 273 & 16.88 & \\
\hline Clothing & 32 & 1.98 & 18 buttons \\
\hline Furniture & 1 & 0.06 & \\
\hline Kitchen & 964 & 59.62 & 720 bottle glass \\
\hline Personal & 19 & 1.18 & 4 coins \\
\hline Total: & 1,617 & 100 & \\
\hline
\end{tabular}




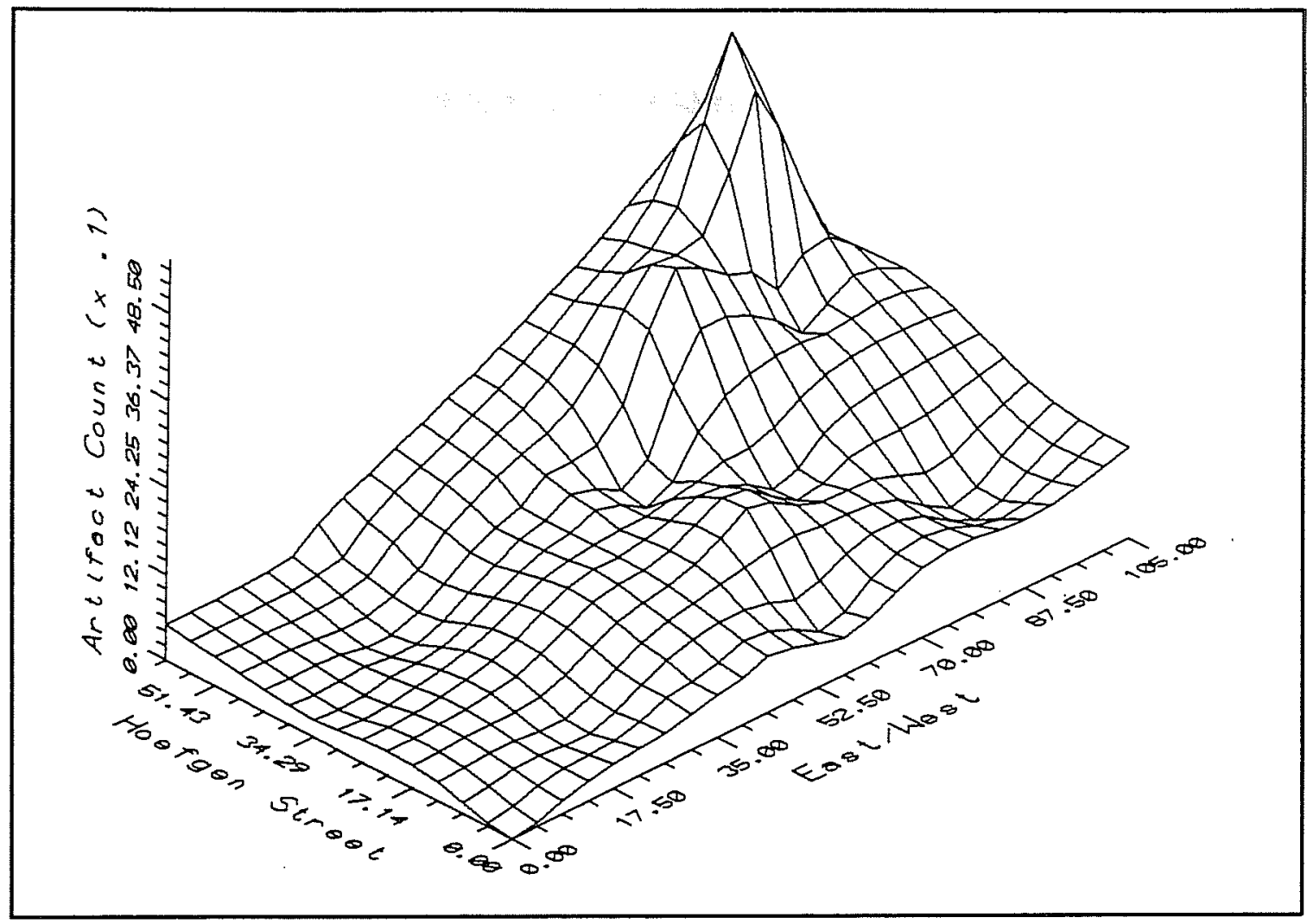

Figure 4-7. 41BX882, spatial frequency of artifacts across the site.

2) The depression present in the absence of the dwelling was often partially filled with architectural debris and other refuse.

3) In pier-and-beam structures, remnants of cedar post often project above the ground. If the lot had been used extensively subsequent to the removal of the dwelling, the chances of having surviving posts was reduced.

In the case of $41 \mathrm{BX} 882$, the primary dwelling was removed late (after 1970) and had not been used extensively since the lot was abandoned. Remnants of cedar piers were extant on the surface, but showed evidence of decomposition. The depression present under where the house had stood was filled with a large amount of architectural debris, primarily asbestos siding tiles, presumably from the structure itself.

\section{BX883-NCB 621, Lot 9}

Test excavations were carried out on this lot from July 27 to August 21, 1990 (Figure 4-5). The lot measured $63 \mathrm{ft}$ north/south and about $200 \mathrm{ft}$ east/west, with most of the initial work carried out on the western twothirds of the lot (Figure 4-8). The Sanborn maps (Figure 4-4) indicated that since 1904 six major structures had been present on the lot. The primary residence faced onto Plum/Hoefgen Street (street numbers 320/520) and appeared to have been replaced between 1911 and 1952. A centrally located building was initially designated as a dwelling (3201/2) in the 1904 map and noted as an outbuilding in the other two maps. A large carriage house was pictured fronting onto Grape Street in the 1904 map, but with an address of $320^{1} / 3$ Plum Street. This carriage house is still present in the 1911 map; however, by 1952 had been replaced by two shotgun-style dwellings fronting onto Grape Street (121 and 125 Grape Street). 


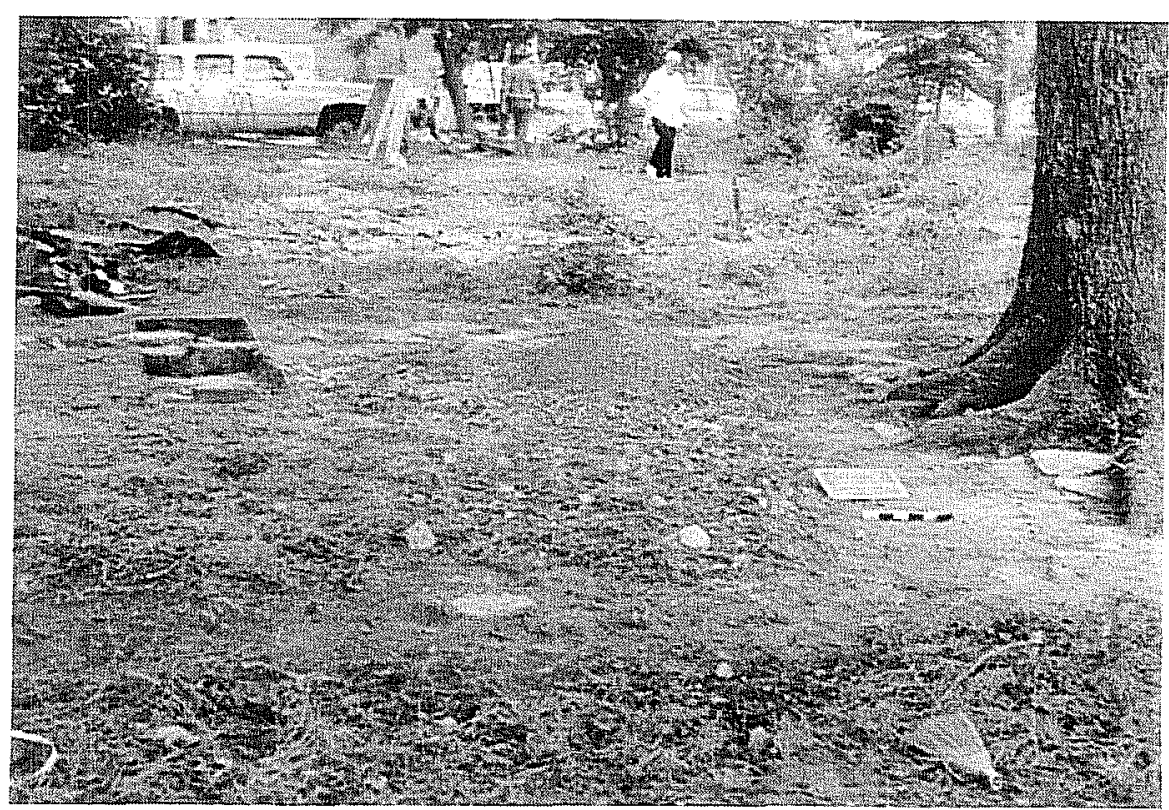

Figure 4-8. 41BX883 west.
(41BX897, the Webb Site) became apparent. (For details regarding the site overlap see below and the section discussing 41BX897.)

A site datum (elevation $650.81 \mathrm{ft}$ amsl) was established in the southwest corner of Lot 9, with the baseline running north and east. Fifteen 2-x-2-ft test units were placed from $30-97 \mathrm{ft}$ east and from 5-58 $\mathrm{ft}$ north. We decided to put most of the handdug test units on the west side of the lot, while backhoe trench testing would be concentrated to the east side. Six backhoe trenches (A-F) were placed on the east side of Lot 9 (Figure 4-5).
When investigations began, only one structure was present on the site. This was the small shotgun-style house located on the east side of the lot fronting on Grape Street (121). However, structural remnants of at least two other buildings were readily visible on the surface. A concrete front doorstep and remnants from 125 Grape Street were present. Remnants of a structure at 520 Hoefgen were also visible in the form of two brick fireplace hearths, a concrete sidewalk that would have approached the front door, and a large quantity of asbestos shingles and other assorted architectural material filling a low spot where the house had presumably stood. The pier-and-beam structure pictured in the 1904 Sanborn map as fronting on Plum Street (320), hereafter referred to as Structure A, was constructed for Cornelius King-for whom the site was named-in 1884. Mr. King is listed in the city directories as a vegetable dealer (CDs 1883-1884, 1885-1886, 1887-1888). In 1890 the property was sold to Adolph Klar, a butcher; the property remained in the Klar family until 1916 (BCDR 79:75).

\section{Excavations (Figure 4-5)}

Many interesting features were discovered on this site, and over time a significant overlap of this site (41BX883) with the site immediately to the north

\section{Structure A}

As mentioned previously, remnants of a structure that had fronted on Hoefgen Street were visible on the surface at the time testing began. In addition to the concrete sidewalk that approached the dwelling location, two enigmatic 17-x-17-inch brick squares (Features A and B) were discovered. Oral history from an informant who had seen the house before it had been removed indicated that the squares were the foundations for fireplace hearths within the frame structure (Bill Pitman, personal communication 1990). Archaeological investigation could not confirm this.

Excavation did reveal four cedar posts in association with the dwelling location. The area beneath where the dwelling had stood was about six inches lower than the surrounding ground surface. Much of this depressed area was filled with asbestos siding tiles. It is apparent from examination of the Sanborn maps that sometime between 1911 and 1952 the original house occupying this location had been razed and a new structure built in its place. Oral history indicated that the structure present on this lot in the 1980s was over 50 years old (Bill Pitman, personal communication 1990). When the property was sold by the Klar family in 1916, a new residence was probably erected. The cedar posts that were located cannot be directly associated with one or the other of the structures which occupied this position. 
The house shown on the 1952 Sanborn map is alleged to have burned in 1987 (Bill Pitman, personal communication 1990), no archaeological evidence to confirm this was found. Some stratigraphic evidence was present to indicate the location of the north wall of the structure in unit N37E65. A very distinctive horizontal soil break running across the unit in an east/ west direction was found. The north side of the unit contained a grey gravelly soil, while the south side of the unit contained a soft, light-colored caliche. This break was similar to one encountered at 41BX881 (see 41BX881 this report) in the vicinity of the house edge.

\section{Structure B}

This structure is pictured on all the Sanborn maps from 1904-1952. In 1904 it is listed as a dwelling (3201/2 Plum), but no such designation is given on the 1911 or 1952 maps. Microscopic examination of an aerial photograph (Figure 4-2) taken of the project area in the 1950 s shows a small structure present in this location, which is centrally located on Lot 9 near the south boundary line. The quality of the photo is not sufficient to determine the type of construction material used in this structure; however, it does appear as if the entrance to the structure was on the north side of the building, as a very noticeable trail approaches the structure on that side. The last owner of the property indicated that in the 1960 s a small dilapidated frame structure was present in this location; the structure was so unstable that the only thing holding it up was a large tree against which it leaned (Bill Pitman, personal communication 1990).

Archaeological testing in this location revealed the presence of a limestone foundation measuring about $15 \mathrm{ft}$ north/south and $32 \mathrm{ft}$ east/west (Figure 4-9). The foundation contained two major elements. The western portion of the structure was represented by a limestone square, $18 \times 15 \mathrm{ft}$. Approximately 60 percent of the structure was complete, the entire south wall and a portion of the east wall were missing. The stones composing the square averaged $1.5 \times 2 \mathrm{ft}$ in size and were laid in double thickness, creating a foundation averaging $2.5-3.5 \mathrm{ft}$ thick. The interior floor of this square was dirt (Figure 4-10). The second major component of this structure was a limestone floor, approximately $5 \times 15 \mathrm{ft}$, located immediately east of the stone square part of the building and justified to the north side of the structure. The edges of the limestone surface appear to be well defined and no disturbance was noted (Figure 4-11). No cedar posts were found to indicate a superstructure to this foundation. The north wall of the limestone square part of the foundation was bisected by a very large pecan tree. Consultation with tree specialists indicated that this tree was between 50 and 75 years old (Wolfe Nursery staff, personal communication 1992). Since the tree bisects the foundation, the latter is most likely older. Since this was the first limestone foundation encountered during the testing phase, and since we were operating on such a limited historical base regarding this structure, we could not make any definite statement regarding its age.

During the Phase III mitigation of 41BX897 (the Webb site) on the next lot to the north (Lot 7), we were required to dig a sizable approach trench to a limestone well we were excavating. This approach trench was so large ( $41 \mathrm{ft}$ north/south, $23 \mathrm{ft}$ east/west) that it extended a significant distance into 41BX883. Investigations at 41BX897 had revealed an occupation that was significantly earlier (ca. 1866) than what was believed to be the initial development of site 41BX883 (ca. 1887). During the excavation of the approach trench to the well on 41BX897, we discovered that the Webb family, who owned Lot 7 , had erected a series of outbuildings across the lot line, onto Lot 9 which they did not own (see 41BX897 this report). The presence of spongeware, blue edge-decorated ware, and Davenport transfer ware on 41BX883 in direct association with the remains of these outbuildings leaves little doubt as to their association with the Webb occupation on 41BX897. If the Webbs were building frame outbuildings on Lot 9 before it was sold to Cornelius King in 1887, they may have also constructed this limestone structure (Structure B).

Unfortunately, few units were placed around the exterior of Structure B and the closest approach of the previously mentioned trench is about $20 \mathrm{ft}$ from Structure B. It should be noted that this was the only limestone foundation on which we could not fix a construction date based on information found in the archives. In all other cases where a limestone structure was built in this neighborhood, the structure dated to the $1850-1860$ period. Therefore it is highly likely that Structure B is associated with the occupation and activities of the Webb family on 41BX897 and that site 


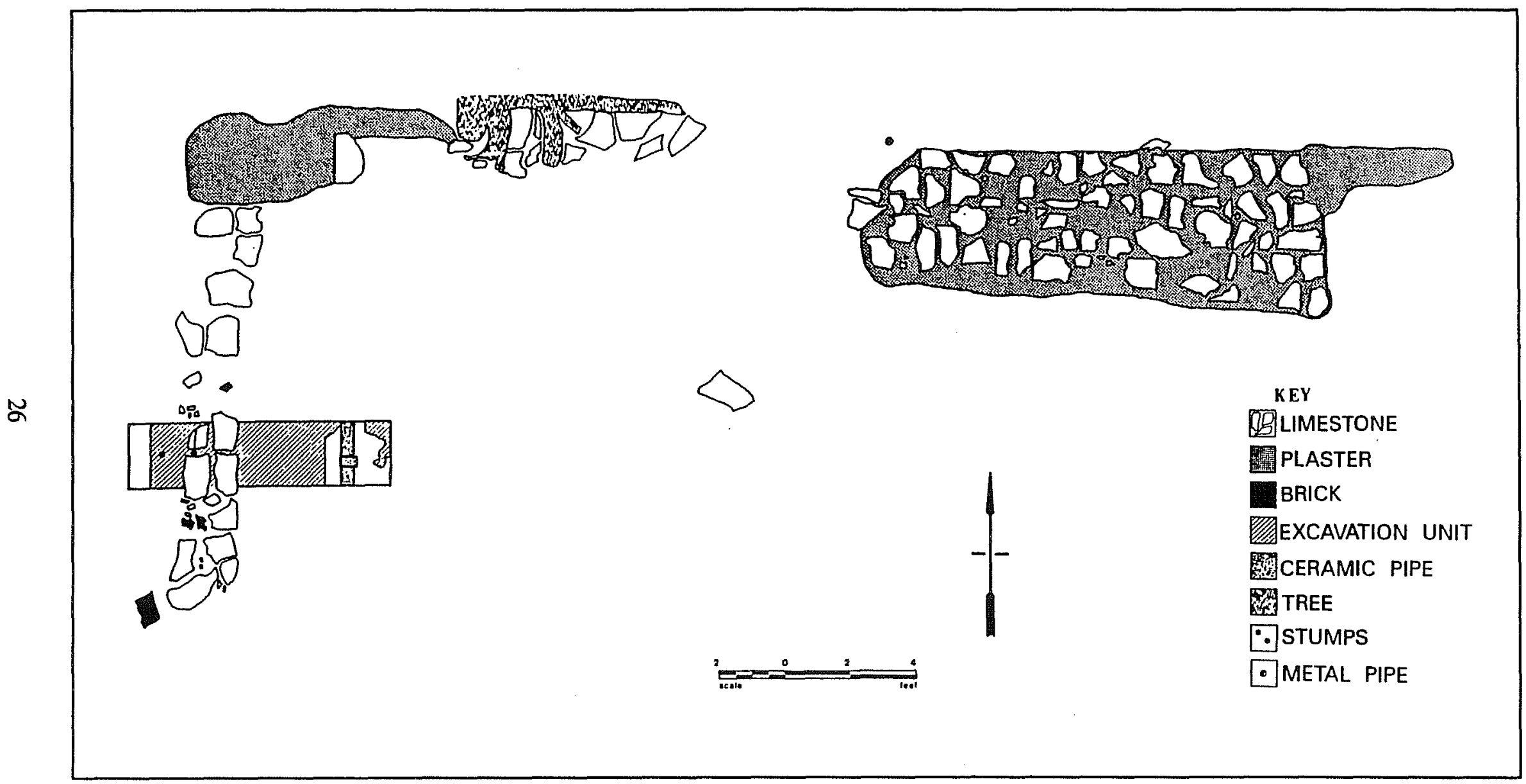

Figure 4-9. 41BX883, Structure B foundation. 


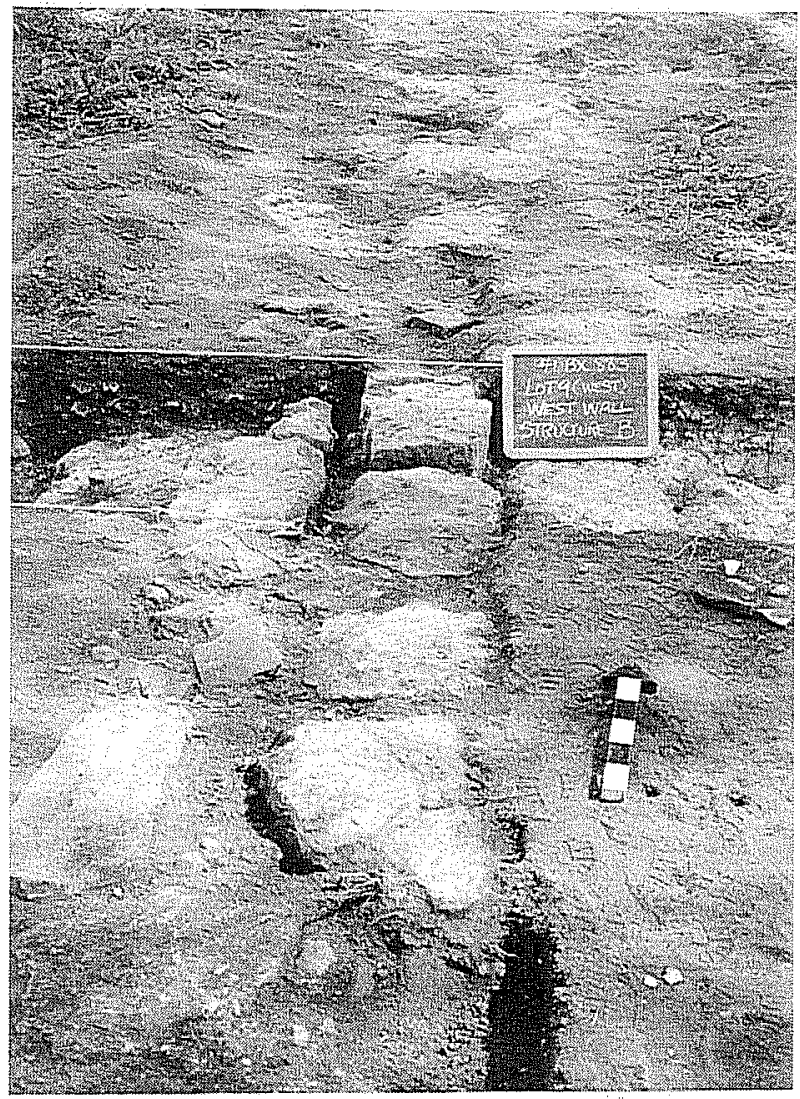

Figure 4-10. 41BX883, Structure B west.

overlap between that site and $41 B \times 883$ occurs. This interpretation is discussed further in the section of the report dealing with $41 \mathrm{BX} 897$.

\section{Backhoe Trench B}

Trench B was placed on the east side of Lot 9 in an east/west orientation about $10 \mathrm{ft}$ inside the north boundary line and $106 \mathrm{ft}$ from Hoefgen street to the west end of the trench. Two cedar posts were found in this trench which were later found to be associated with outbuildings constructed by the Webb and Deman families just north of the property line on 41BX897. One post was located nine feet east, at a depth of around 18 inches. The second post was located $24 \mathrm{ft}$ east in the south profile of the trench, also at about 18 inches depth. Both posts were four inches in diameter. The association of the posts with $41 \mathrm{BX} 897$ will be further discussed in the section dealing with that site.

\section{Backhoe Trench C - Feature A}

Located $138 \mathrm{ft}$ east of Hoefgen Street and four feet inside the south boundary of Lot 9, what was originally started as Backhoe Trench $\mathrm{C}$ revealed the remains of a brick privy vault which was designated Feature $A$ (Figure 4-12). The brick vault was square-shaped and measured $63 \times 63$ inches. The first course of bricks was encountered six inches below the ground surface, and from this first course extended to a depth of 63.25 inches below the surface. Although the brick vault had retained its structural integrity, it did display a marked "bowed in" aspect on all four walls. This was to be a common feature observed in almost all of the later privies encountered in the project area. In some cases pressure from the outside soil led to a total failure of a privy's structural integrity (see 41BX892 - Feature A). A cedar post was found 10 inches south of the center of the privy's south wall, at a depth of nine inches. It is likely that this post represents part of the original superstructure for the privy (for further detail on the privies and their contents see Brown and DeLaO, Volume III).

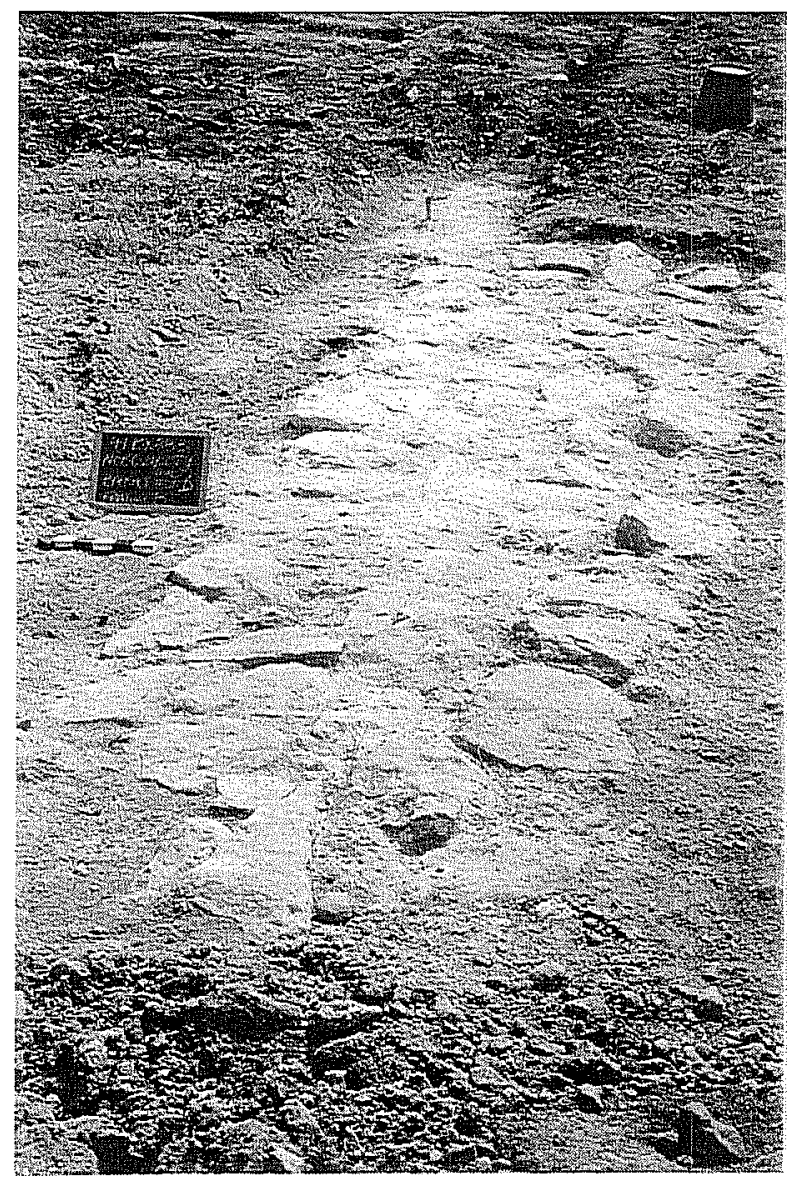

Figure 4-11. 41BX883, Structure B east. 


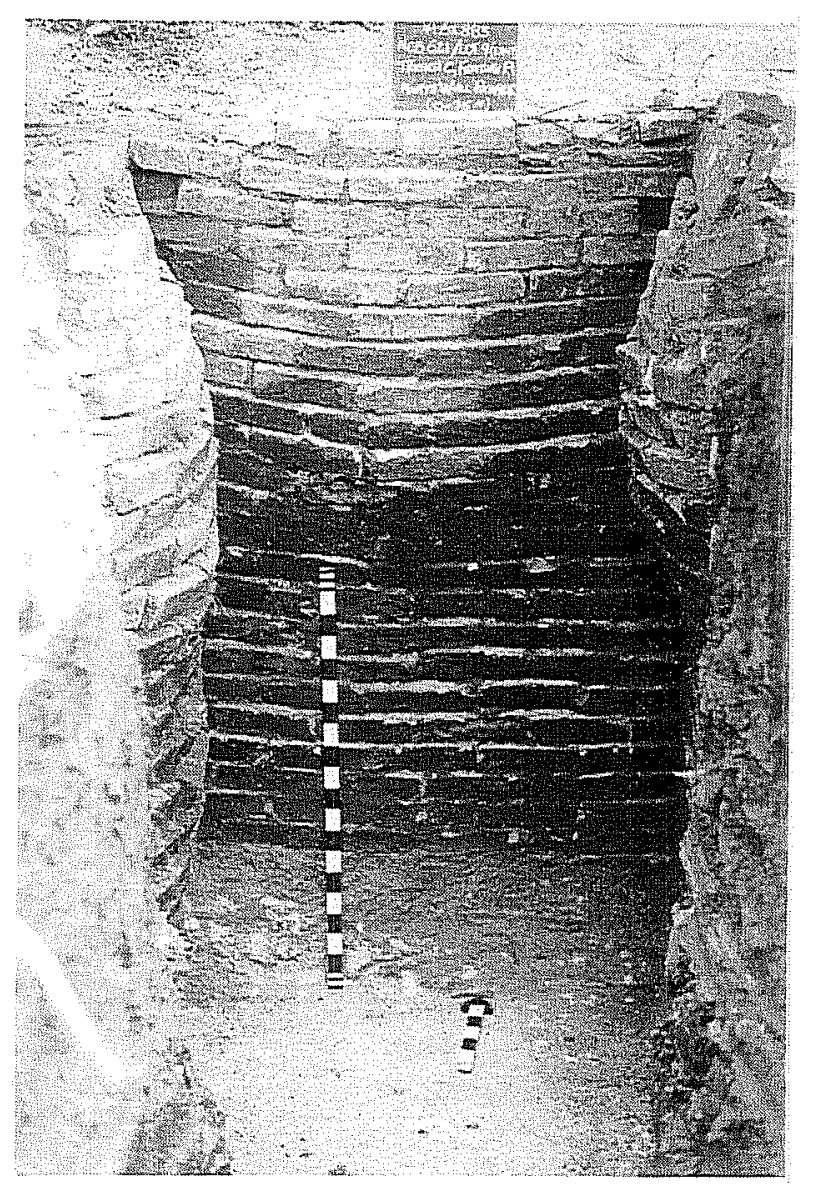

Figure 4-12. 41BX883, Feature A, brick-lined privy.

\section{Backhoe Test E - Feature B}

The 1911 Sanborn map indicates a small (10-x-10-ft) structure as being present in the central part of the east side of Lot 9. Backhoe Trench $\mathrm{E}$ was placed to investigate if any remains of this small structure were intact and, if so, to attempt to determine its function. Three cedar posts about four inches in diameter were revealed, outlining the northwest, northeast, and southwest corners of a $10-\mathrm{x}-10-\mathrm{ft}$ structure (Feature B). The interior of the structural zone was composed of a light-colored caliche soil, while the east and west exterior displayed a very distinctive burned clay soil.
A four-inch metal water pipe ran at a slight southeast to northwest angle through the structural zone. Within the burned-soil zone, one sherd of blue edge-decorated ceramic (ca. 1850-1860) was recovered. This was the first diagnostic artifact suggesting an earlier occupation of 41BX883. It is likely that the edgeware was not associated with the small structure, but with the outbuildings built by the Webb and Deman families just to the north of this area. No function could be ascribed to Feature B; however, based on the nature of the surrounding soil and the burned aspect of the tops of the cedar posts which were revealed, it is likely that it burned down.

\section{Artifact Group Distributions and Comments}

Table 4-5 shows the percentages of artifact group distributions from the site. Figure 4-13, which shows the artifact density of the west half of Lot 9 , indicates the highest occurrence of artifacts is on the northcentral part of the lot. This was within an area occupied by outbuildings built by the Webb/Deman family who lived on Lot 7 (41BX897). As has been previously noted, there is an overlap between the two sites. This overlap undoubtedly affected the artifact profile of this site.

The west side of the lot had been vacant since 1986 . The area where the original house (520 Hoefgen) stood was visible as a large depression which was filled partially with architectural debris, primarily asbestos siding tile. Several cedar posts were still present above the ground surface. Evidence of child play similar to that described by Wilk and Schiffer (1979) was present in the remnants of a tree house which was built in a large pecan tree near the south border of the lot (this was the same tree which bisected the foundation of Structure B). 
Table 4-5. Site Artifact Frequency Distributions for 41BX883

\begin{tabular}{|c|c|c|c|}
\hline Group & $\#$ & $\%$ & Notes \\
\hline Activity & 214 & 2.72 & \\
\hline Architecture & 2,591 & 32.98 & 1,591 wire nails; 431 cut nails \\
\hline Arms & 1 & 0.01 & 1 cartridge \\
\hline Bone & 2,669 & 33.97 & \\
\hline Clothing & 70 & 0.89 & 53 buttons \\
\hline Furniture & 578 & 7.36 & 576 lamp parts \\
\hline Kitchen & 1,670 & 21.26 & 1,251 bottle glass \\
\hline Personal & 63 & 0.80 & 26 glass figurine frags; 10 pen/pencil \\
\hline Total: & 7,856 & 100 & \\
\hline
\end{tabular}

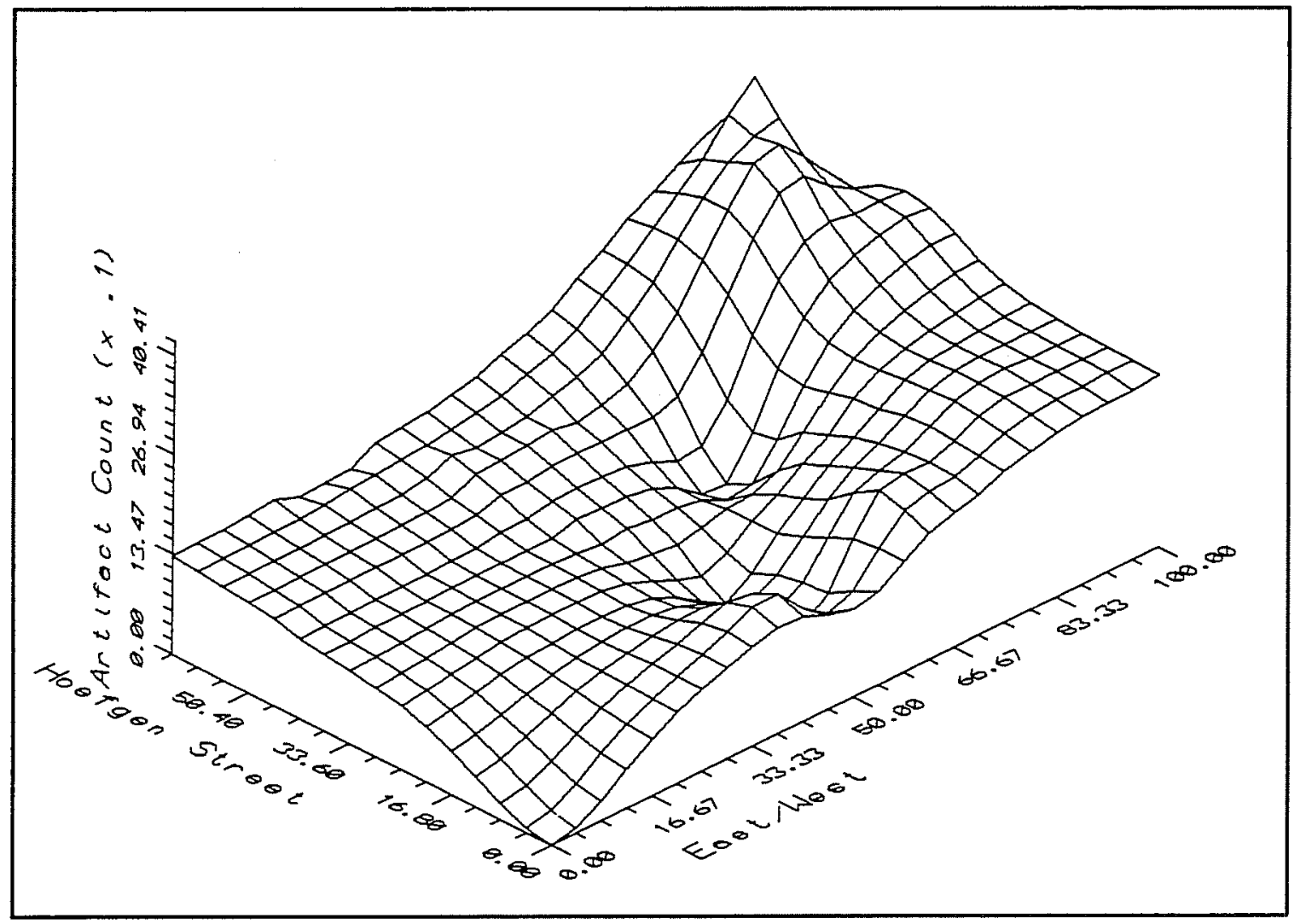

Figure 4-13. 41BX883 west, spatial artifact frequency across the site.

\section{BX884 - NCB 620, Lot 12}

This site occupies the southern half of Lot $12, \mathrm{NCB}$ 620, 123 Nevada Street (Figure 4-14). Test excavations were conducted here from August 2 to August 9, 1990. The site was given the designation 41BX884, the Griesenbeck House. At the time investigations were started, two structures were present on this portion of the lot: a solid limestone T-shaped Victorian house fronting on Nevada Street (Figure 4-15), and a contemporary garage constructed of cinderblocks located in the northeast corner of the existing yard.

The Victorian home was the only one of its type constructed of stone within the project area. It was 


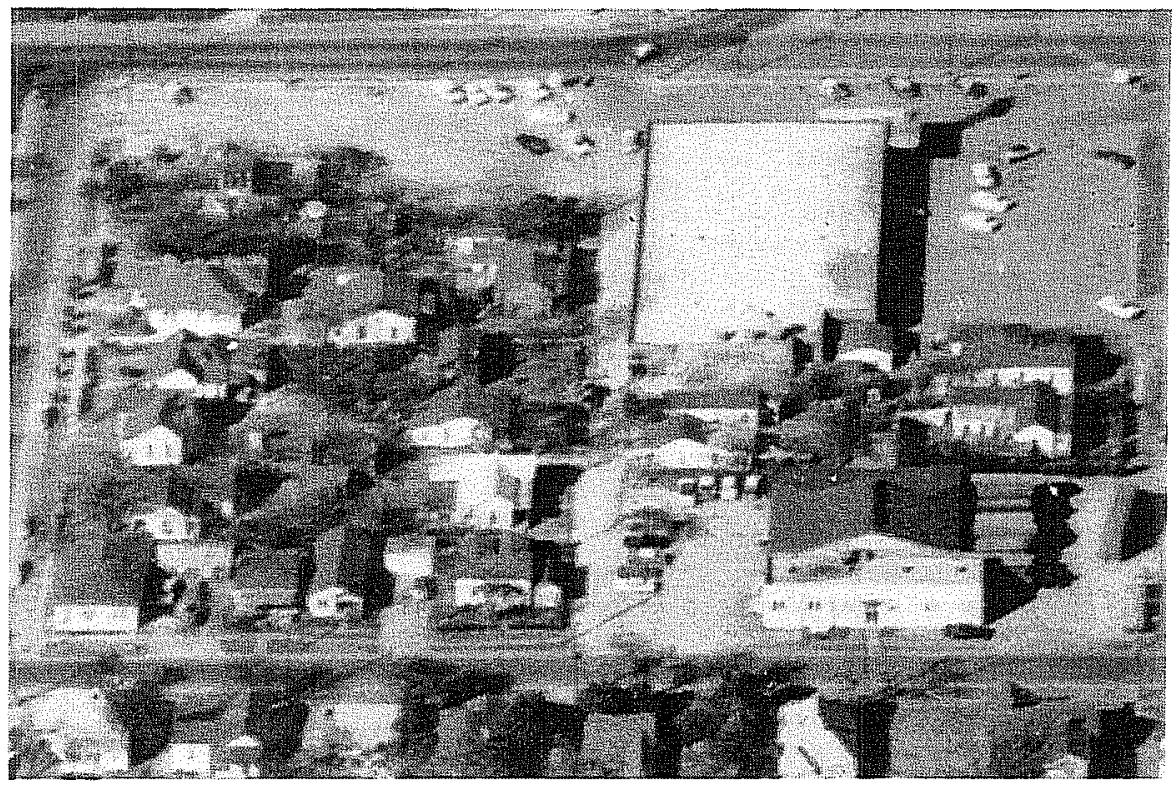

Figure 4-14. NCB 620, ca. 1955. Facing west.

regarded by the architects who examined it as the most solid home within the project area (Andrew Perez and Associates 1990). This dwelling was constructed around 1883 for an August Roatzsch who, with his wife Marie, resided on the property until 1901 . The house was then acquired by Arthur Griesenbeck, for whom the site was named. Griesenbeck lived in the home until 1929 (BCDR 25:622, 195:102; Mechanic's Lien, Bexar County Courthouse, San Antonio, Texas, B:29).

The Sanborn maps show a significantly larger structure than what was visible when investigations began on the site (Figure 4-16). The 1904 and 1911 maps indicate the north and south halves of Lot 12 were not subdivided and that a second structure was located along the western boundary line of the northern end of the lot. By 1952 (Sanborn map) Lot 12 had been subdivided into two sections measuring about $100 \mathrm{ft}$ north/south. Unfortunately the northern half of Lot 12 could not be investigated because, before the project began, the whole north side of NCB 620 was torched by vandals and despoiled by construction crews dumping refuse. Thus the north side of NCB 620 was both an unhealthy and an unsafe place to work, so testing was confined to the southern half of Lot 12.

In 1968 clearance was done for a new highway, IH37 south, that would be running through the area. The entire portion of NCB 620 west of Lot 12 was destroyed. This put a house that had formerly rested in the center of a block into a cul-desac, making it the last house on the block. In addition, the clearance work for the right-ofway for the highway was likely to have created significant disturbance along the western boundary line of Lot 12.

\section{Excavations (Figure 4-17)}

A site datum (elevation $650.13 \mathrm{ft}$ amsl) was established on Nevada Street at the southeast corner of Lot 12. Fifteen 2-x-2-ft test units were excavated on the site. Most of the units were located within the existing backyard, near household exits, and within areas

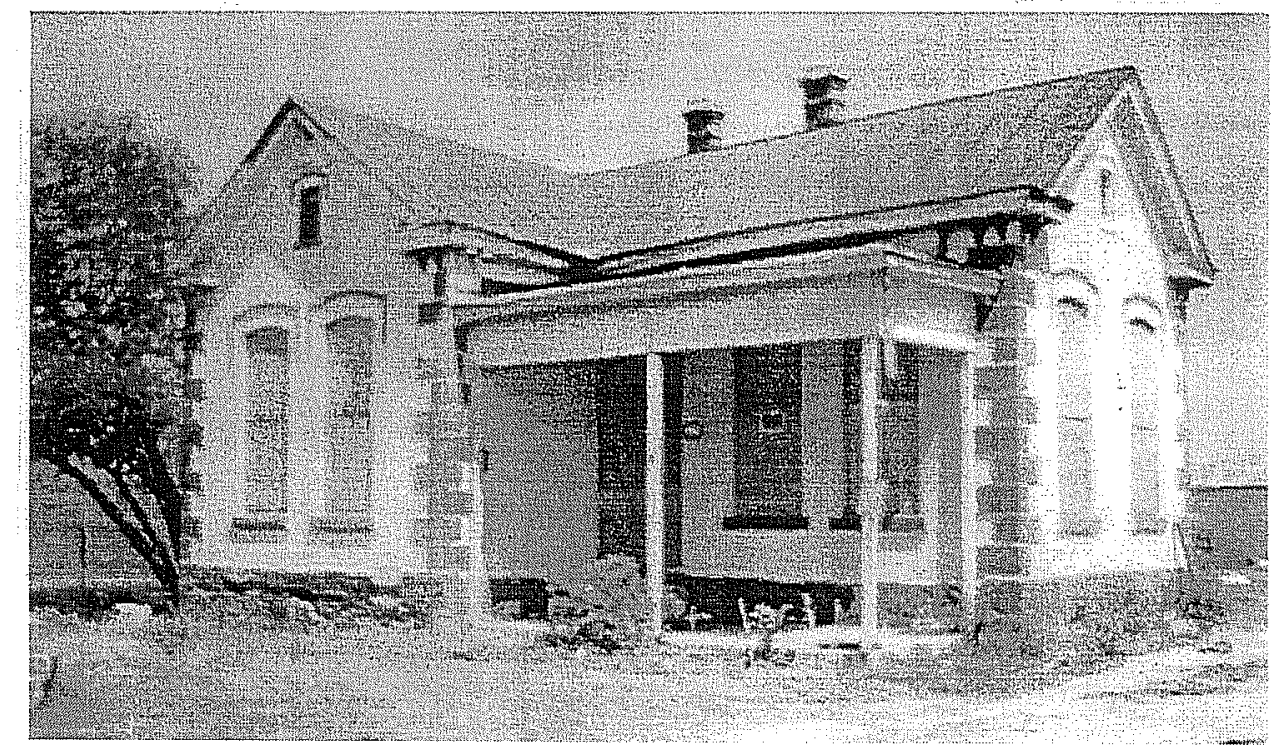

Figure 4-15. The Griesenbeck house. 


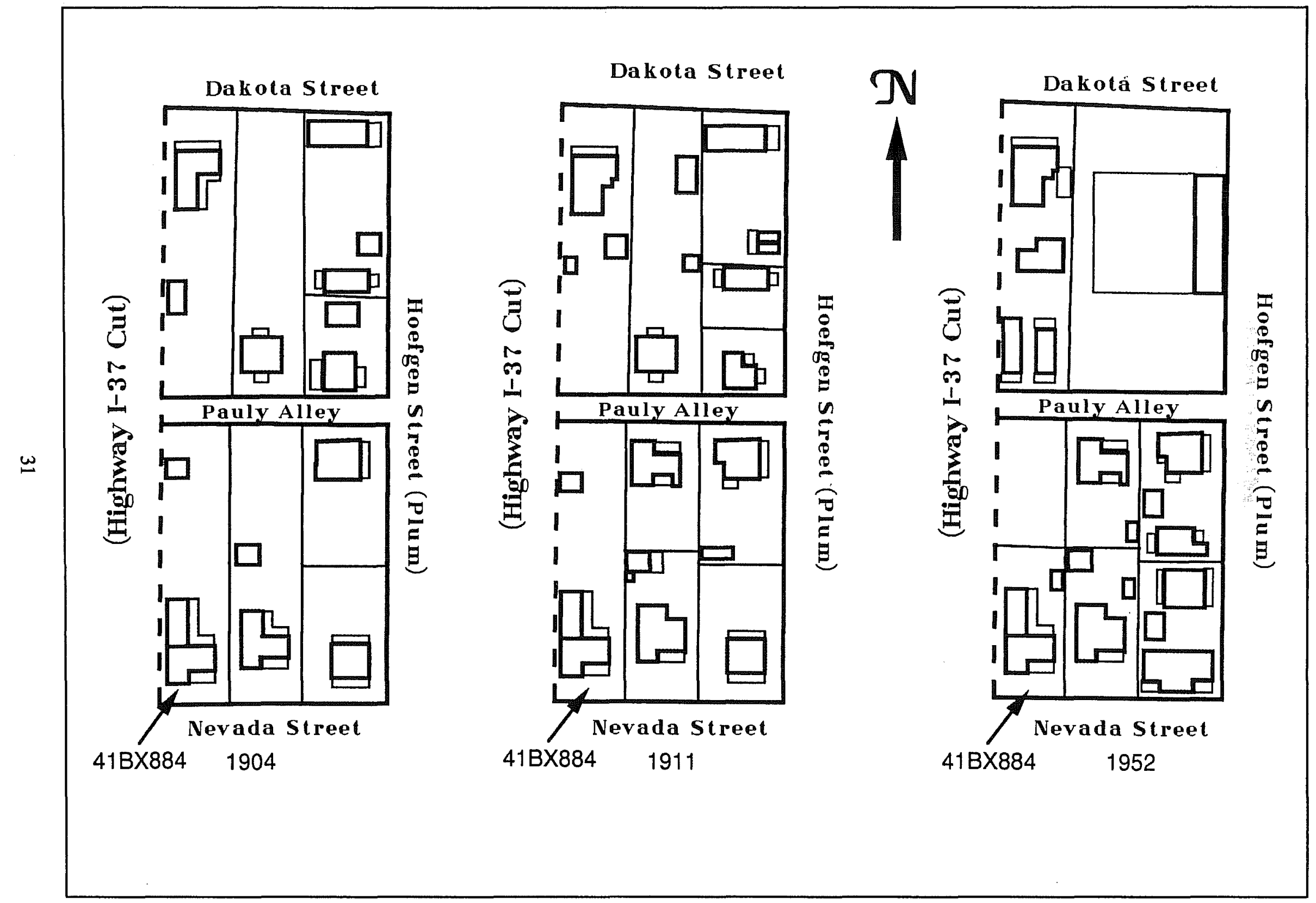

Figure 4-16. NCB 620. Adapted from Sanborn maps. 


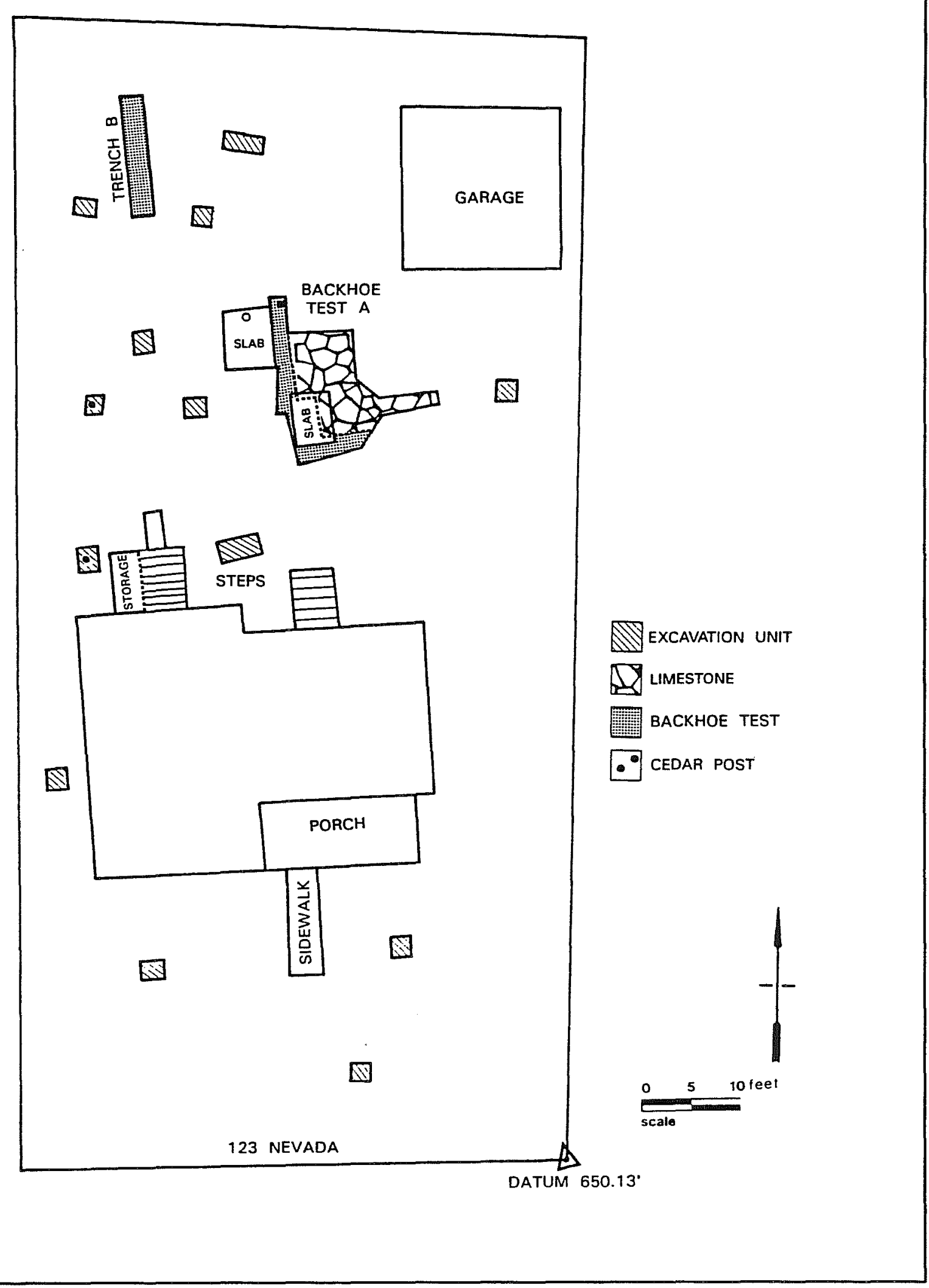

Figure 4-17. 41BX884, site map. 
shown by the Sanborn maps as being formerly occupied by portions of the house. The only surface evidence that the dwelling had ever been larger than at present was the existence of two small concrete slabs centered in the backyard. One of the slabs contained a small water drain. In addition to the 2-x-2-ft units, two backhoe tests were also performed. One test was conducted in the northeast corner of the yard; the other was performed in the proximity of the two previously mentioned concrete slabs.

Various structural elements were revealed by the test units and backhoe trenches. $A$ series of cedar posts and concrete post molds confirmed the presence of a pier-andbeam annex to the stone dwelling (Figure 4-18). A large flagstone surface running to the east of where the annex would have

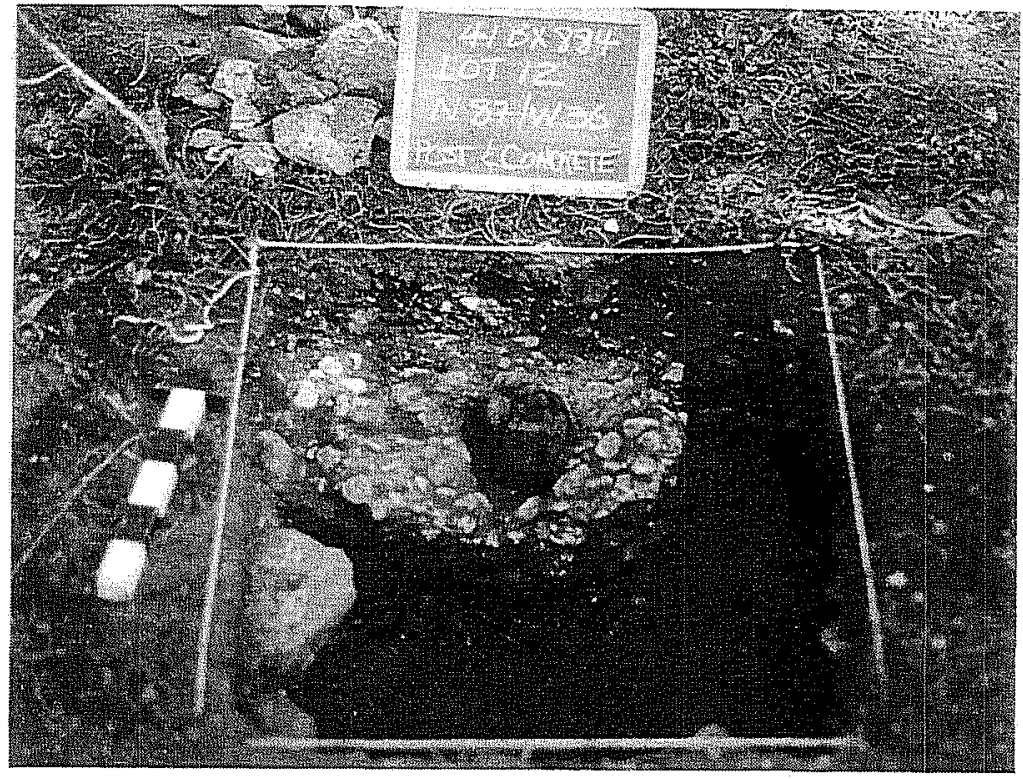

Figure 4-18. 41BX884, remnants of piers from former house annex. been was also found. This flagstone surface was surrounded by a more ephemeral surface of brick and plaster (Figure 4-19). A possible prehistoric component was located at N107W27 and N107W29. This was evidenced by the presence of a layer of chert cobbles approximately 10.5 inches below the surface, with some showing evidence of testing. This was an isolated feature and did not show up in Backhoe Trench B just to the west or in N99W32.
The pier-and-beam annex to the primary stone dwelling appears to have run about $33 \mathrm{ft}$ from the north side of the stone structure and to have been $20 \mathrm{ft}$ wide. It would have encompassed the small concrete slab containing the water drain. The west edge of the limestone surface (Feature A) appears to have been placed just outside of the east wall of the pier-andbeam annex. The second small concrete slab is positioned to have been a convenient doorstep entering the annex from the east side at a time when the limestone surface was no longer visible on the surface. Indeed the limestone surface ran under this concrete slab and was buried at a depth varying from 3-5 inches below the existing ground surface. The small concrete slab had the engraved initials "R. J. L.," "S. L.," and "M. L. L." and the date "2/9/1954." Unfortunately none of these initials matches residents of the house at that time. 


\section{Artifact Group Distributions and Comments}

Table 46 shows the artifact group distributions for this site. Figure 4-20, the spatial frequency for artifacts across the site, indicates that the largest quantities of artifacts were derived from an area near the northeast corner of the yard. This would have been directly adjacent to a contemporary cinderblock garage which was in the northeast corner of the yard (Figure 4-17).

Table 4-6. Site Artifact Frequency Distributions for 41BX884

\begin{tabular}{|c|c|c|c|}
\hline Group & $\#$ & $\%$ & Notes \\
\hline Activity & 363 & 10.60 & 82 plastic frags. \\
\hline Architecture & 1,464 & 42.73 & 497 wire nails; 369 window glass \\
\hline Arms & 12 & 0.35 & 8 cartridges; 3 gun flints; 1 musket ball \\
\hline Bone & 558 & 16.29 & \\
\hline Clothing & 74 & 2.16 & 45 buttons \\
\hline Furniture & 4 & 0.12 & 2 light bulb frags.; 1 lamp part; 1 furniture part \\
\hline Kitchen & 916 & 26.74 & 738 bottle glass frags. \\
\hline Personal & 35 & 1.02 & 7 mirror glass \\
\hline Total: & 3,426 & 100 & \\
\hline
\end{tabular}

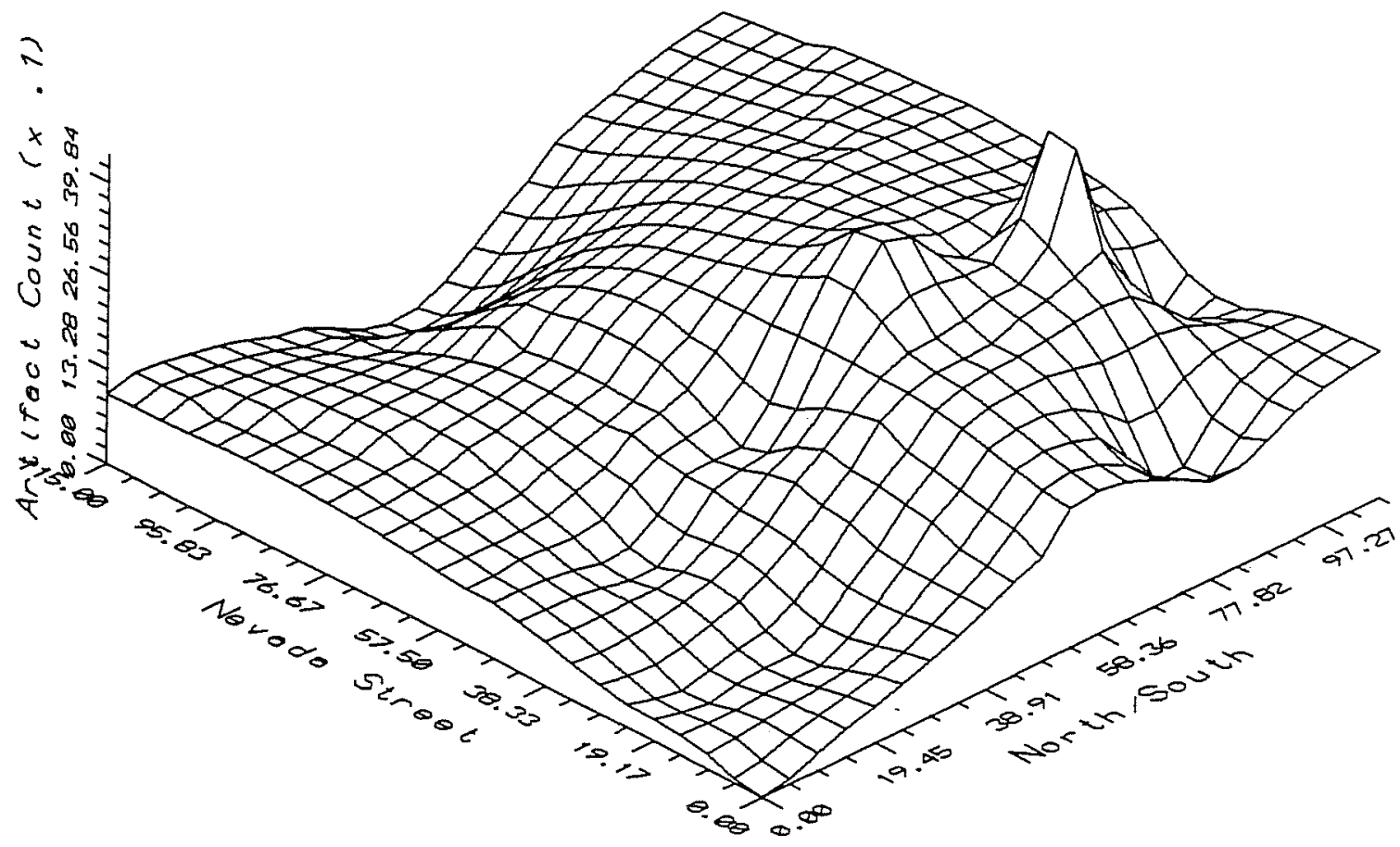

Figure 4-20. 41BX884, artifact spatial frequency across the site. 


\section{BX885 - NCB 627, Lot 7}

Between August 9 and August 17, 1990 , test excavations were carried out at 41BX885, NCB 627, Lot 7 - The Mendit Shop site (Figure 421). The address of the residence here is 409/609 Plum/Hoefgen (Figure 4-22).

At the time testing was started, three primary structures were present on the lot: 1) a pier-and-beam Victorian-style house facing onto Hoefgen Street to the east; 2) an attached, more contemporary tailor shop also facing onto Hoefgen Street; and 3) a two-room outbuilding facing onto Nevada Street along the west

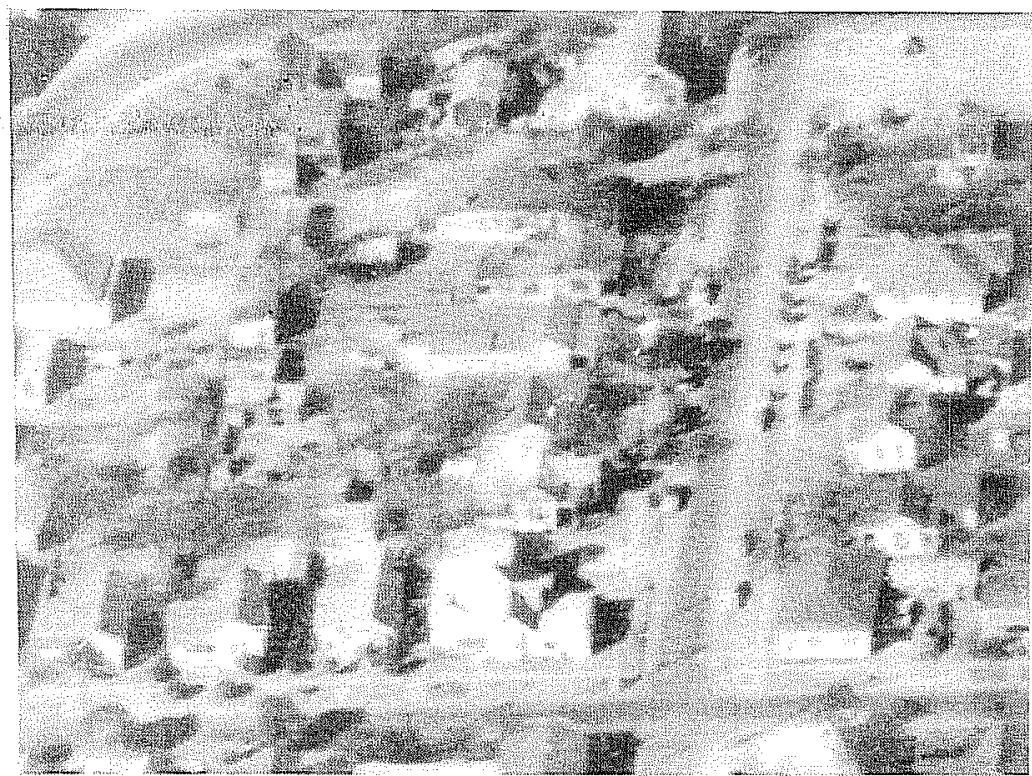

Figure 4-21. NCB 627, ca. 1955. Facing west. boundary line.

The first resident of the property was Harold Bull, who was listed in the city directories as a bartender (CDs 1891, 1892, 1893). Bull likely had the Victorian home built in 1891. In 1899 the property was sold to the Maffi family, who owned several other homes in the neighborhood and resided in a large home on NCB 628. The house remained in the Maffi family as rental property until about 1925 .
The Sanborn maps from 1904-1952 indicate a residence which matched the description of the Victorian home occupying the lot at the time testing started in 1990. However, the area to the southwest of the house, which on the early maps sported a porch, had been framed into a room. This changed the appearance of the house from a conventional $L$-shaped Victorian into a square.

The Sanborn maps also show a small outbuilding filling the southwest corner of the lot during the period 1904-1952. However, the size

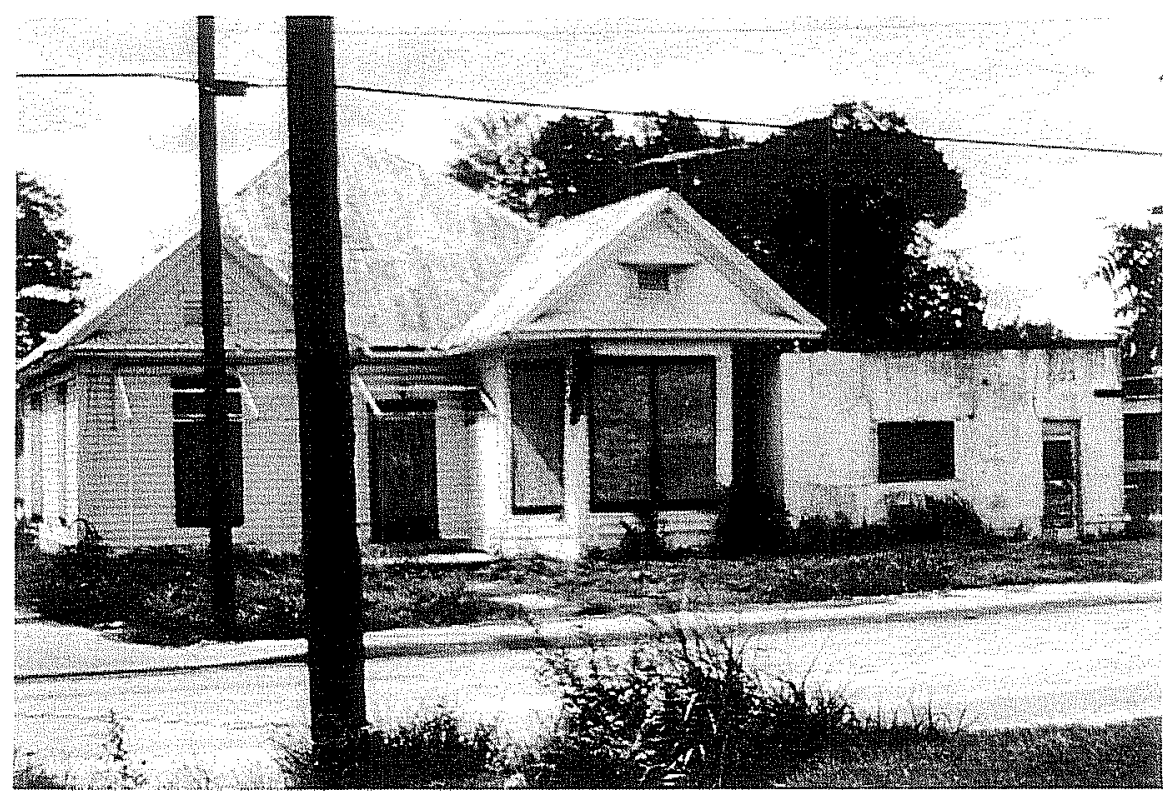
of the outbuilding apparently changed between 1911 and 1952 (Figure 4-23). This could have resulted from adding to an already existing structure, or to the total replacement of a structure. In this case the latter seems to be the more likely because the existing outbuilding is a two-room structure with a dividing wall running longitudinally down the center. Additionally, all elements of the structure appeared to be in an equal state of deterioration and no obvious additions or modifications were evident.

Figure 4-22. The Mendit Shop site. 


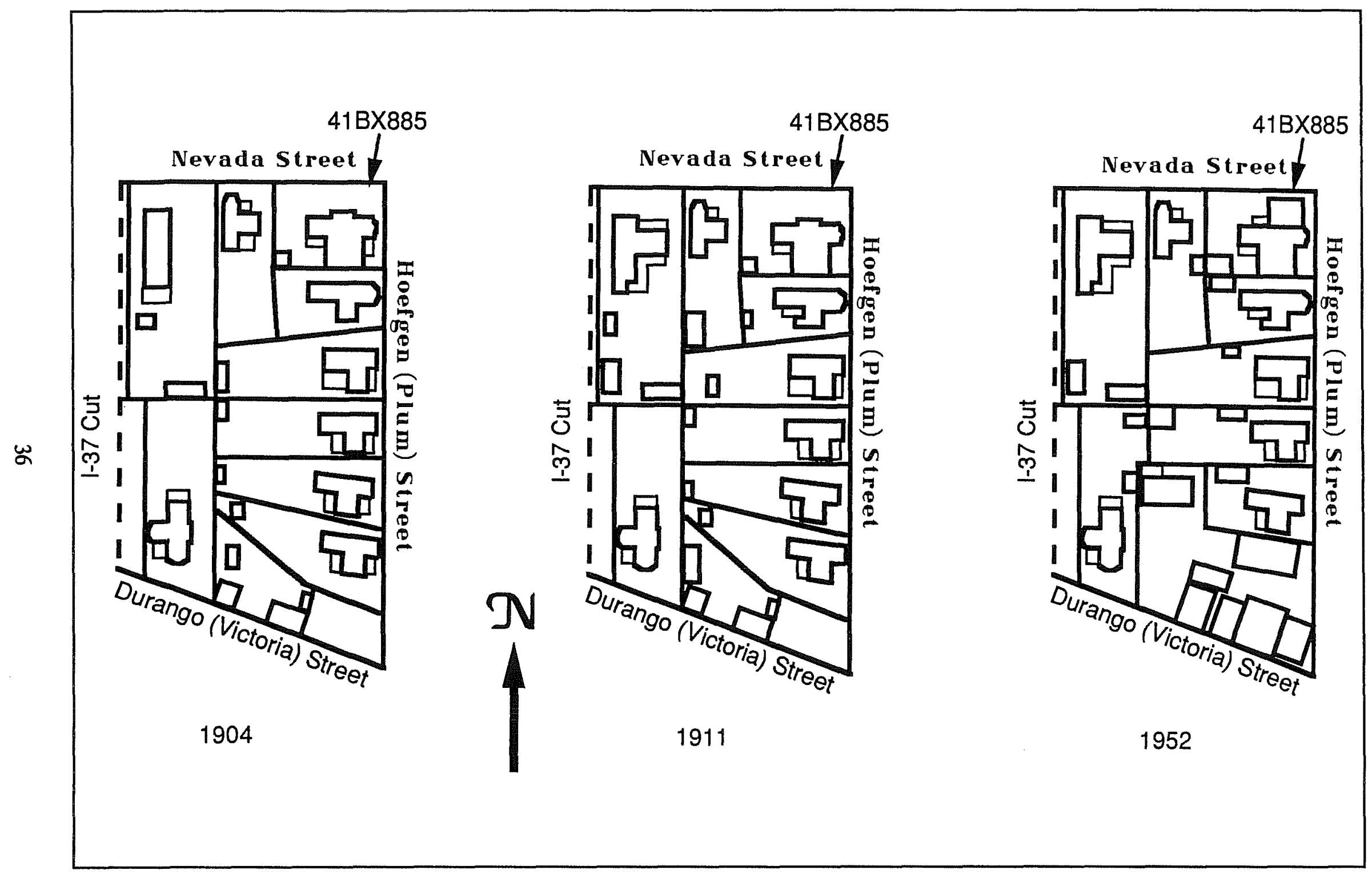

Figure 4-23. NCB 627. Adapted from Sanborn maps. 


\section{Excavations (Figure 4-24)}

A site datum (elevation $650.59 \mathrm{ft}$ amsl) was established at the southeast corner of Lot 7 next to Hoefgen Street, with the baseline running north and west. Ten $2-x-2-\mathrm{ft}$ units were laid out across the lot.

Structural features associated with the relationship of the primary dwelling to the outbuilding were found at N9W71. At 1-2 inches below the ground surface, several limestone pavers were found representing a walkway presumed to have run between the east side of the present outbuilding and the west side of the primary dwelling. This was supported by the fact that the stones were laid with the long axis in a north/south fashion. Below these stones, at a depth of 5-5.5 inches below ground surface, a second walkway surface was exposed. This surface was composed of a mixture of pink and yellow bricks, with some limestone present. The left edge of the walkway was exposed and appeared to crosscut the unit at an angle of approximately $140^{\circ}$ north/south. This would have been an appropriate angle to approach a smaller outbuilding such as the one pictured on the 1904 and 1911 Sanborn maps if the exit from the house had existed in the southwest corner of the original Victorian structure. A doorway inside the present house at this location appears to be part of the original construction.

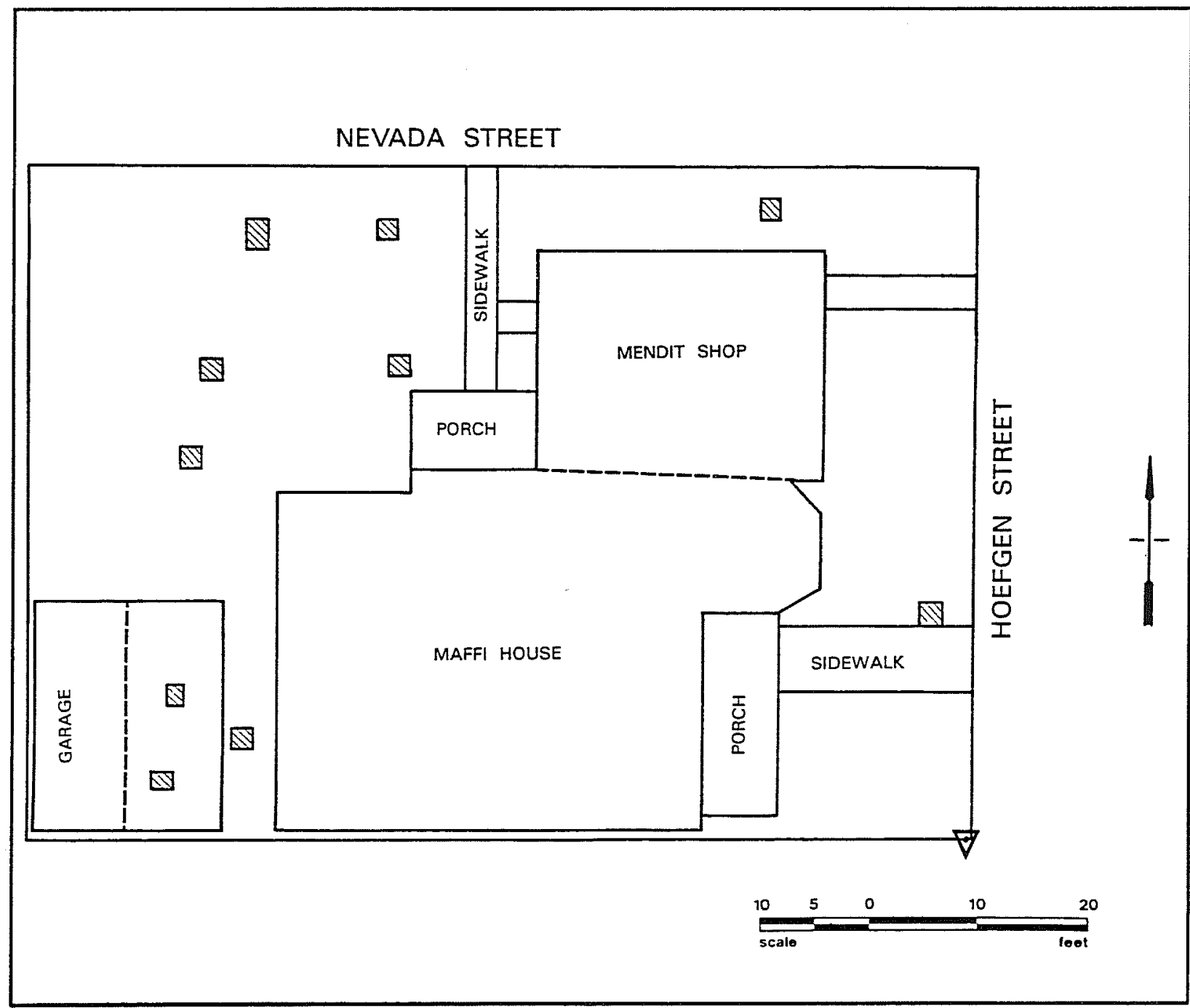

Figure 4-24. 41BX885 site plan. 


\section{Artifact Group Distributions and Comments}

Table 47 shows the group distribution percentages for this site. Figure 4-25 shows the spatial frequencies of artifacts excavated from this site. The southwest corner of the lot, occupied by a small outbuilding complex, shows the highest density of artifacts. The outbuilding complex was placed in a "family back region" as described by Portnoy (1981), this being the most secluded part of the lot. Although a tailor shop was present on this site, an interior examination of which revealed much discarded clothing, it was not represented well in the archaeological record. This was probably due to the fact that since the shop was built on a concrete-slab floor, there would be no loss of artifacts through the floor. It was surprising, however, not to find a better representation of clothing-group artifacts around the entries and exits of the building.

\section{NCB 613 (North) Three Sites}

Starting on August 8 and running through August 27, 1990 , work was conducted on three sites located on the north side of NCB 613 (Figure 4-26). This was an area which up until that time had been covered with a large industrial building (Lewis Equipment Company) and had been unapproachable.

Early Sanborn maps $(1904,1911)$ indicate several adobe structures had faced Wyoming Street from NCB
613 (Figure 4-27). Further archival research indicated that these residences dated from the 1850 s and were of primarily German occupancy (CDs). The entire west side of NCB 613 had been destroyed in the middle to late 1960 s with the construction of IH37. Only three of the residential foundations that had existed on NCB 613 north could have survived the highway construction.

Once the Lewis Equipment Company building had been removed and the overlying concrete taken up, it was obvious that a different approach to testing of these sites would have to be implemented. The entire lot was covered with approximately 6-8 inches of heavy caliche base material that had to be removed prior to any hand excavation. The majority of the southern half of NCB 613 was deemed unsuitable for testing due to the presence of several large subsurface fuel tanks that had contaminated the surrounding soil. These tanks were in the process of being removed at the time we were testing on the north side of the lot. Major soil disturbance was created by the removal of the subsurface fuel tanks.

We decided to concentrate our efforts on the north side of the lot. Due to the heavy overburden of base material, much of the preliminary work would have to be done with the backhoe. The initial research design had hypothesized that most of the major features encountered on sites would be located close to the property lines. With this in mind several objectives were targeted:

Table 4-7. Site Artifact Frequency Distributions for 41BX885

\begin{tabular}{|c|c|c|c|}
\hline Group & $\#$ & $\overline{\%}$ & Notes \\
\hline Activity & 94 & 10.56 & 44 rubber frags. \\
\hline Architecture & 363 & 40.79 & 225 wire nails \\
\hline Arms & 0 & 0.00 & \\
\hline Bone & 181 & 20.34 & \\
\hline Clothing & 10 & 1.12 & 6 buttons \\
\hline Furniture & 0 & 0.00 & \\
\hline Kitchen & 240 & 26.97 & 140 bottle glass frags. \\
\hline Personal & 2 & 0.22 & 1 slate frag.; 1 comb frag. \\
\hline Total: & 890 & 100 & \\
\hline
\end{tabular}




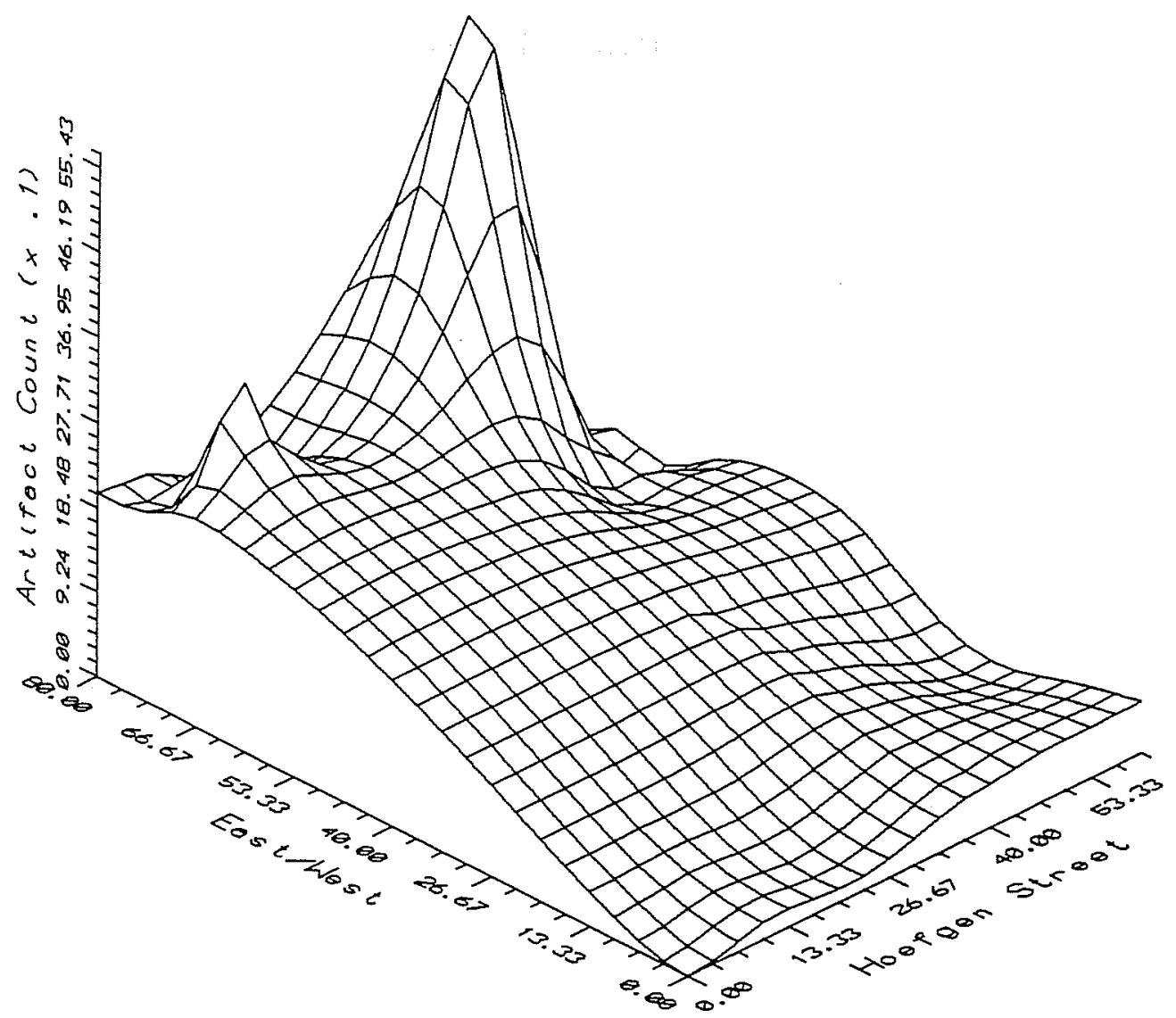

Figure 4-25. 41BX885, spatial frequency of artifacts across the site.

1) determine if the foundation elements of the original dwellings were still present beneath the base material; and, if so,

2) uncover enough of the foundations to reconstruct the shape of the dwellings; then using this data with the Sanborn maps, reconstruct the locations of the original lot boundaries;

3) place backhoe trenches parallel to the reconstructed lot boundaries back to a distance approximately $100 \mathrm{ft}$ south of the dwellings;

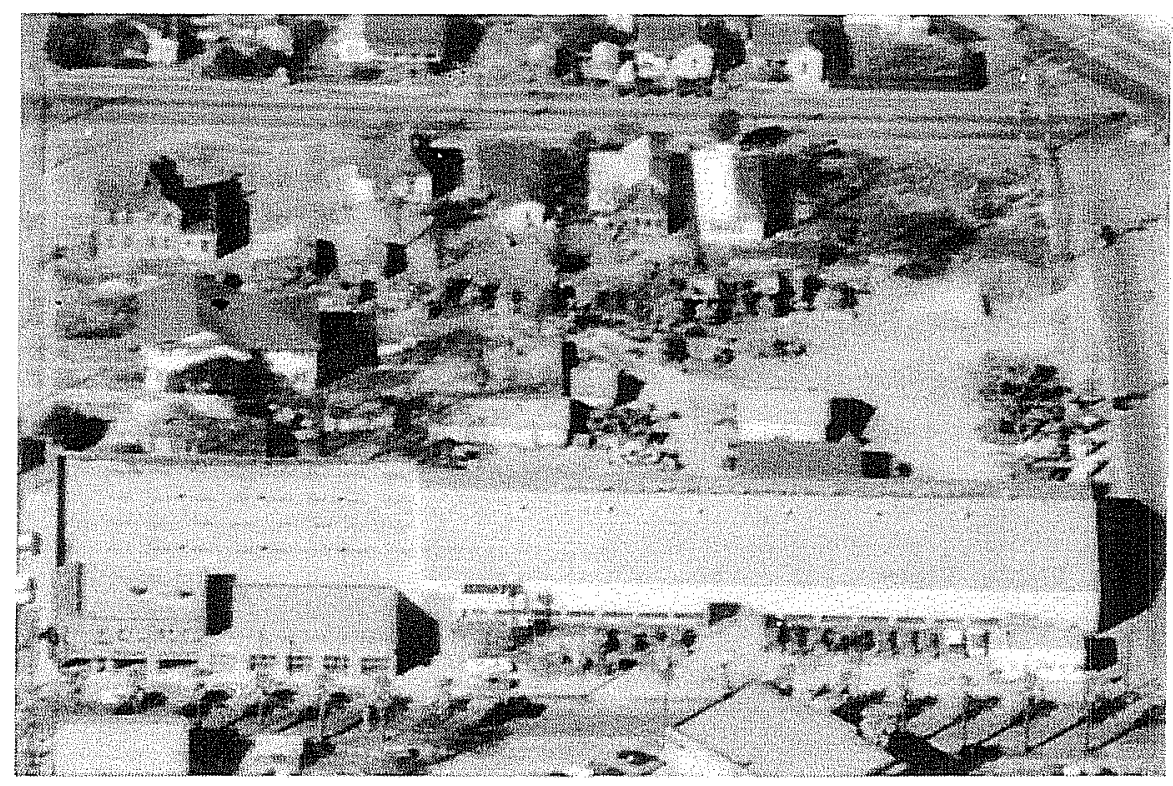

Figure 4-26. NCB 613, ca. 1955. Facing west. 


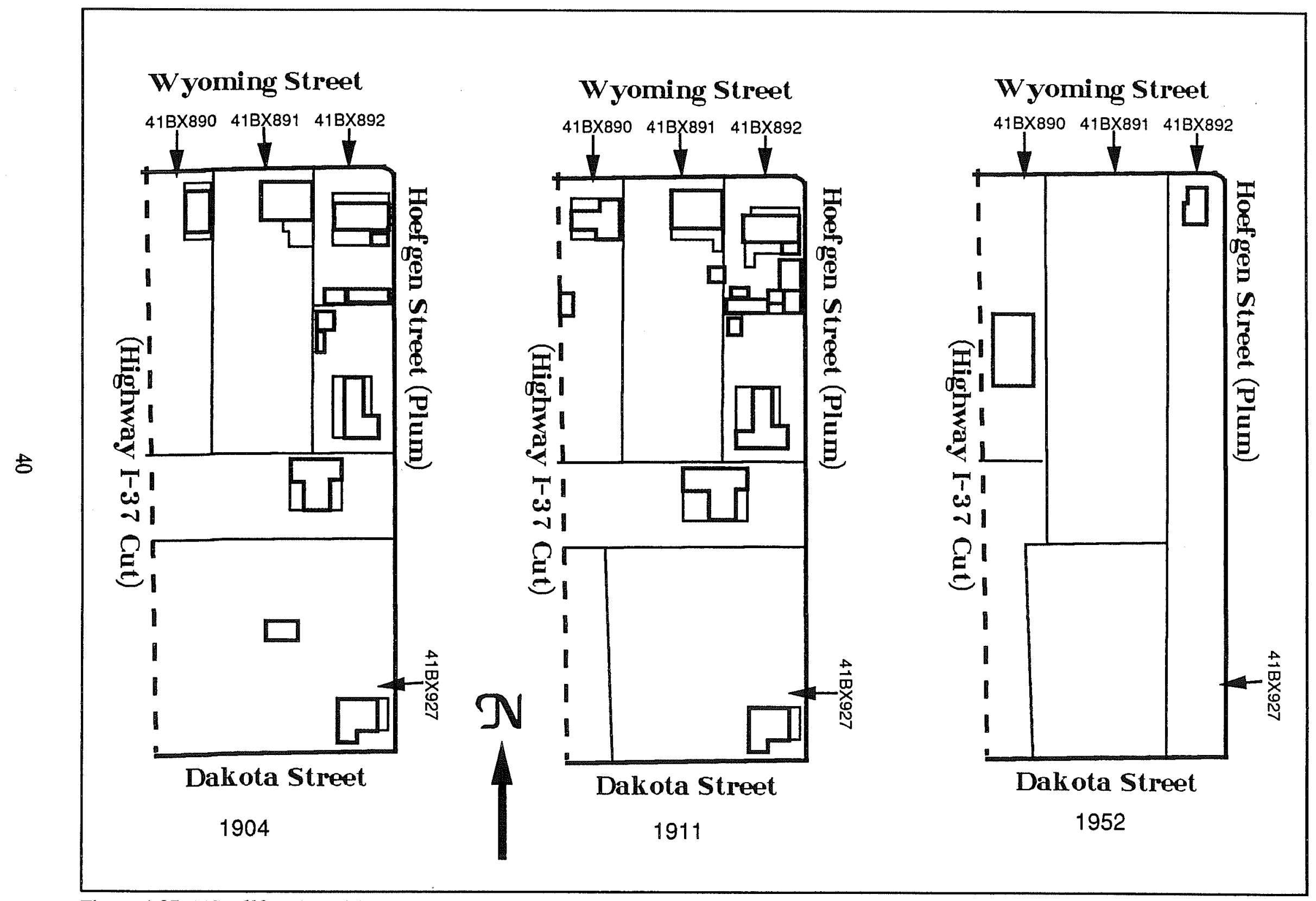

Figure 4-27. NCB 613. Adapted from Sanborn maps. 
Following this strategy, three sites were recorded (41BX890, 41BX891, 41BX892) and six backhoe trenches were run (Figures 4-28 and 4-29). Due to the construction of the industrial building over this area, all intact living surfaces had apparently been removed; however, several deeper features were still present. The individual sites and their details are described below.

\section{BX890 - NCB 613, Lot 4}

Located on NCB 613, Lot 4, 122 Wyoming Street, this site was designated 41BX890, the Biesenbach site (Figure 4-28). The limestone structure present on this property was constructed in 1859 by John Houzeau, who had acquired the land in two transactions (BCDR $\mathrm{R} 2: 523, \mathrm{H} 2: 387)$. He first acquired 18.5 varas on the east side of the lot, then gained four additional varas on the west side of the lot. In 1862 the property was purchased by Peter Biesenbach, who also owned several other lots in the area (BCDR S2:218). The site was named after this individual.

The 1904 Sanborn map shows a small dwelling facing on Wyoming Street near the east boundary of the lot. There was also an indication that the house was of adobe construction (Figure 4-27). Archaeological investigations in San Antonio have revealed that in most cases buildings marked on Sanborn maps as "adobe" in most cases are not really adobe constructions. In the Alamodome Project excavations,

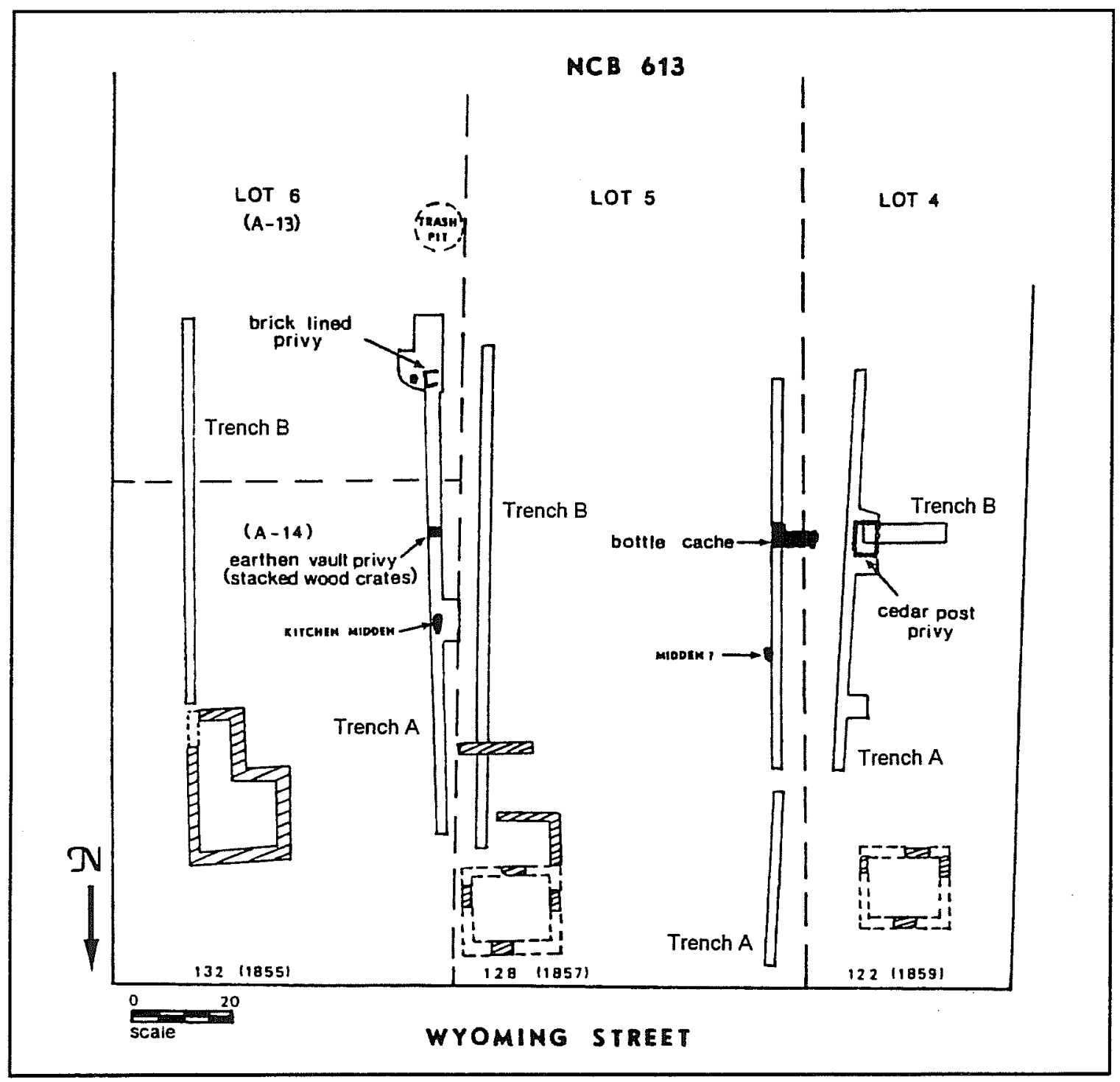

Figure 4-28. NCB 613, site map (41BX890, 41BX891, 41BX892). 
dwellings listed as adobe were actually found to be one of three different materials: 1) irregular limestone chunks or nodules (sometimes chert) set in mortar; 2) mortared or dry-laid rectangular or square-cut hard limestone blocks; 3) mortared square to rectangular cut soft caliche blocks.

On the 1911 Sanborn map, the dwelling present on this site is no longer listed as adobe and has taken on a Victorian $T$ shape. An addition may have been added to the west wall of the earlier structure, or the earlier structure could have been razed and a totally new structure erected. Archival research indicates that by 1925 all residences on this part of the block were abandoned. By 1952 the dwellings are gone and an industrial complex has been introduced over the area.

\section{Excavations}

A site datum (elevation $655.23 \mathrm{ft}$ amsl) was established $14 \mathrm{ft}$ west of the southwest corner of Hoefgen and Wyoming streets. This datum was approximately $246 \mathrm{ft}$ west-southwest of one of three primary datums used during the project, Monitor Well 312 (elevation $653.81 \mathrm{ft}$ amsl).

Of the structural foundations present on the north side of NCB 613 (Lots 4, 5, and 6), we decided only the foundation on Lot 6 would be fully exposed. Foundation elements for the early residence on this site (41BX890) were found approximately 12 inches below the existing ground surface, which was represented by the top of the heavy caliche base material. The foundation rested in a darker, thick clay soil just beneath the lowest level of the base material. Only about 18 inches of the foundation base remained vertically. No living surfaces were present and no artifacts were recovered during the foundation exposure process. It was obvious that the foundation had been cut off well below the original ground surface.
Four sections of this foundation were exposed, revealing the front room ( $16 \times 17 \mathrm{ft}$ ) of a small, two-room settlement salt-box style house. This was a popular house type during the mid-nineteenth to early twentieth centuries in San Antonio (Fox, Volume I). During the 1850-1860 period, almost all dwellings of this type were built of stone; in the period after 1870, wooden frame construction was preferred. In the project area, three other stone houses of this type were examined (41BX891, 41BX897, 41BX900). Several other houses of this type have also been recorded in earlier projects in San Antonio, including the Smith House (41BX589) in the HemisFair Plaza area (Cox, personal communication 1990). A house of similar construction was also recorded at 917 South Leona Street during the Vista Verde South Historical Survey; this was one of the last examples of this type of house in the area (Breig and Associate/Architect 1979). However, up until the Alamodome Project, no homes of this type had been excavated in San Antonio.

\section{Trenches A and B}

Trench A was placed running in a north/south direction on the east side of $\operatorname{Lot} 4$, approximately five feet inside of the reconstructed east lot boundary line. The north end of the trench was located $42 \mathrm{ft}$ south of Wyoming Street. A cedar-post-lined privy vault was discovered about $42 \mathrm{ft}$ south into the trench. This would have been $50 \mathrm{ft}$ behind the south wall of the 
dwelling. The privy vault measured 44 inches east/ west and 56 inches north/south (Figure 4-30). The average diameter of the cedar posts which comprised the vault lining was 3.5 inches. The sides of the vault exhibited the characteristic slumped-in appearance caused by pressure from the outside soil; however, the structural integrity of the vault was still intact. After the surface of the vault had been cleared off and documented, we decided to section the vault with the backhoe. This would be performed by cutting an east/west trench (Trench B) that would enter the privy vault from the west side. The trench would be carried to just inside the east interior wall of the privy and extend down to the lowest level of cultural deposit within the vault. This would allow stratigraphic documentation of the deposits in the vault from top to bottom, and would yield information on the constructional elements of the vault itself (Figure 4-31).

The maximum depth of the vault was 63 inches. Varying layers of humus and clay-like soils of different colors (night soils) interspersed with layers of charcoal and ash were revealed. It was a common practice for persons to dump wood ashes into their privies to discourage the activity of insects and to reduce the smell. Lime was also used for this purpose when available (Brown and DeLaO, Volume III). Few artifacts were recovered from within the vault: several sherds of undecorated whiteware and porcelain, and one sherd of spongeware. The generally accepted date for spongeware distribution in the area is 1853-1871 (Miller 1991); this places the construction date

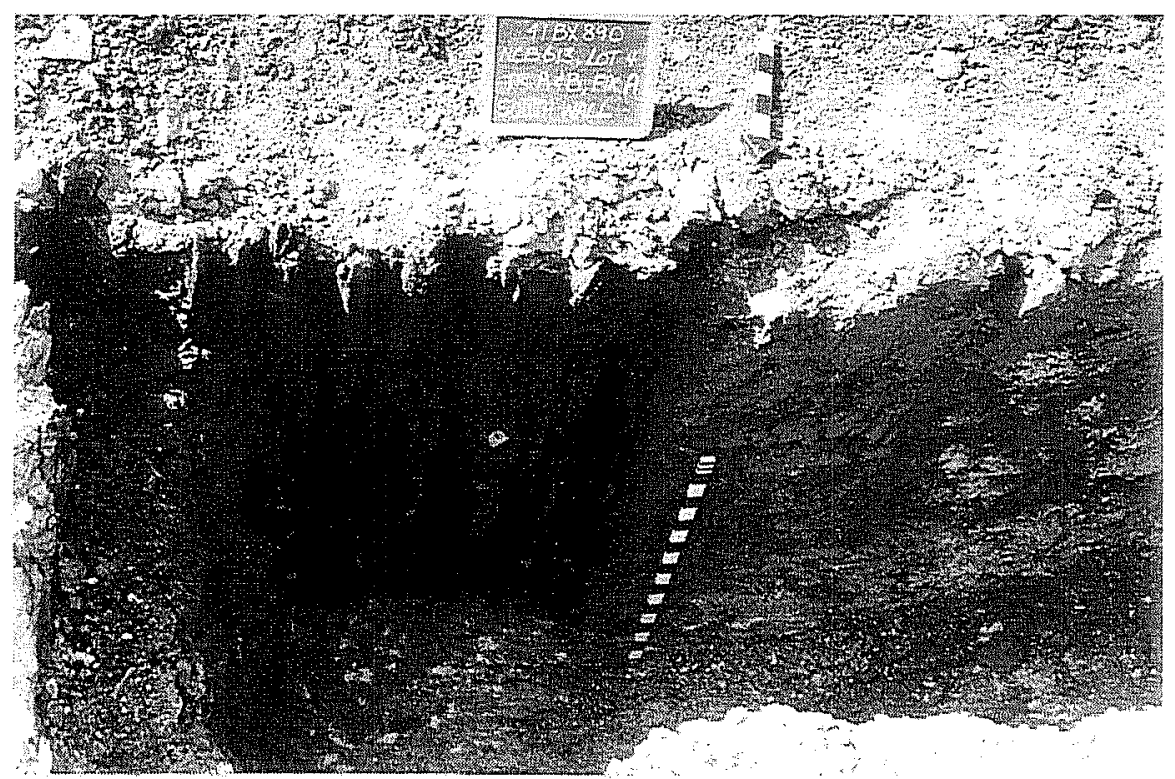

Figure 4-31. Cedar post-lined privy vault, sectioned by Trench $B$.

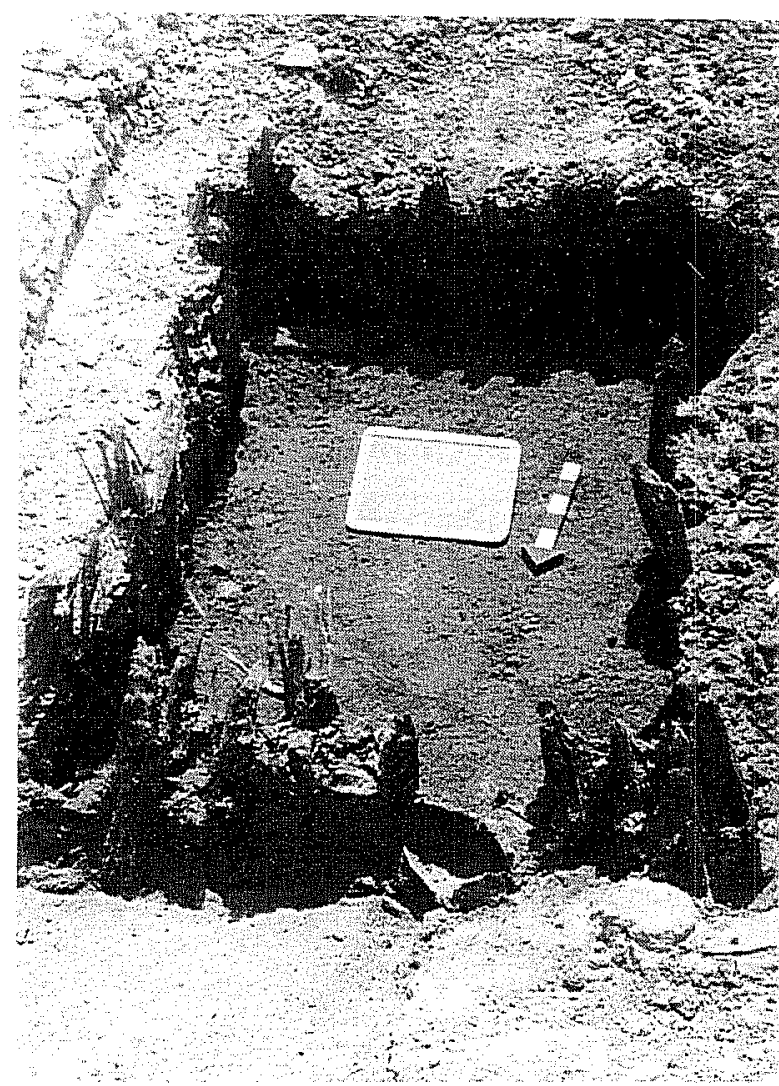

Figure 4-30. Cedar post-lined privy vault (top view).

of the privy within the range of the construction date of the limestone house (1859-1862). This is further supported by the use of cedar posts as a vault-lining material. Brick was not generally available until after the arrival of the railroad in 1877 ; therefore, cedar posts would have made one of the most appropriate lining materials for a privy vault. This is the only cedar post-lined privy ever reported in San Antonio. Most of the privies located within the Alamodome Project area were of brick construction, thus dating to post 1877.

Final measurements for Trench A were $2 \times 80 \mathrm{ft}$, for Trench B $4 \times 26 \mathrm{ft}$. Approximately $715 \mathrm{ft}^{3}$ of soil was excavated within these two trenches. 


\section{Artifact Group Distribution and Comments}

Since this site was covered with asphalt and had been cut down to a level below the previous existing living surface, no sheet refuse deposits were present. Most excavation was performed with a backhoe, with handexcavation used to expose revealed subsurface features. All artifacts revealed in these trenches were the likely result of deliberate trash disposal activity. Table 4-8 shows the artifact group percentage profile.

\section{BX891 - NCB 613, Lot 5}

NCB 613, Lot 5, 128 Wyoming Street, was tested during the same time period as adjacent Lots 4 and 6 (August 8 to August 27, 1990). The first dwelling on the lot was probably built around 1857 by Jacob Renz who sold the property to Joseph Biesenbach in 1858 (BCDR P1:59, R1:61). The property remained in the Biesenbach family until 1887 when it was acquired by John Horn, for whom the site is named (BCDR P1:96).

The 1904 Sanborn map shows a small adobe dwelling in the northeast corner of the lot. A small frame addition on the west side of the house and a large porch on the south side of the house are shown. By 1911 the large porch is gone and has been replaced by a smaller one and two small frame additions, one on the southeast corner and the other along the east property line just behind the house. On the 1952 Sanborn map, the property has been taken over by the
Lewis Equipment Company and all dwellings are gone (Figure 4-27).

\section{Excavations (Figure 4-29)}

The same strategy was followed in testing this site as was followed on the two other lots (4 and 6) on the north end of NCB 613. First the foundation elements of the primary dwelling were isolated, then backhoe trenches were placed five feet inside the property lines and were carried $100 \mathrm{ft}$ behind the structures.

The site datum (elevation $655.23 \mathrm{ft}$ amsl) for this site was the same as the one used for both 41BX890 and 41BX892, located just west of the southwest corner of Hoefgen and Wyoming streets.

Excavations revealed the foundation elements for the primary dwelling. The building was a small, rectangular structure, $20 \mathrm{ft}$ east/west by $28 \mathrm{ft}$ north/ south. It was a two-room structure with the larger of the rooms located toward the front, facing on Wyoming Street and measuring $18 \times 20 \mathrm{ft}$. The smaller room to the rear measured $10 \times 20 \mathrm{ft}$. The southeast corner of the rear room was missing. The foundation was composed of broken limestone pieces set in mortar, and represented a settlement salt-box style house. In addition to the small rectangular dwelling, a wall was discovered running east/west about $12 \mathrm{ft}$ from the south end of the dwelling. This wall was composed of uncut chert and limestone nodules set in mortar (Figure 4-32) and measured $14 \mathrm{ft}$ in length.

Table 4-8. Site Artifact Frequency Distributions for 41BX890

\begin{tabular}{|c|c|c|c|}
\hline Group & $\#$ & $\#$ & Notes \\
\hline Activity & 21 & 4.49 & 6 wire frags; 5 tools \\
\hline Architecture & 141 & 30.13 & 90 cut nails \\
\hline Arms & 3 & 0.64 & 3 cartridges \\
\hline Bone & 64 & 13.68 & \\
\hline Clothing & 7 & 1.50 & 6 buttons \\
\hline Furniture & 16 & 3.42 & 16 lamp parts \\
\hline Kitchen & 212 & 45.30 & 133 ceramics \\
\hline Personal & 4 & 0.85 & 2 slate frags; 1 comb; 1 pipe frag \\
\hline Total: & 468 & 100 & \\
\hline
\end{tabular}


This wall probably represented the south end of the porch area pictured on the 1904 Sanborn map. The east and west sides of this porch were likely of frame construction. This is supported by the length measurement of the wall which comes up five feet short of the west wall of the dwelling. The 1904 Sanborn map indicates that the porch was stepped in from the house proper about five feet.

Two backhoe trenches were placed running north/south five feet inside the east and

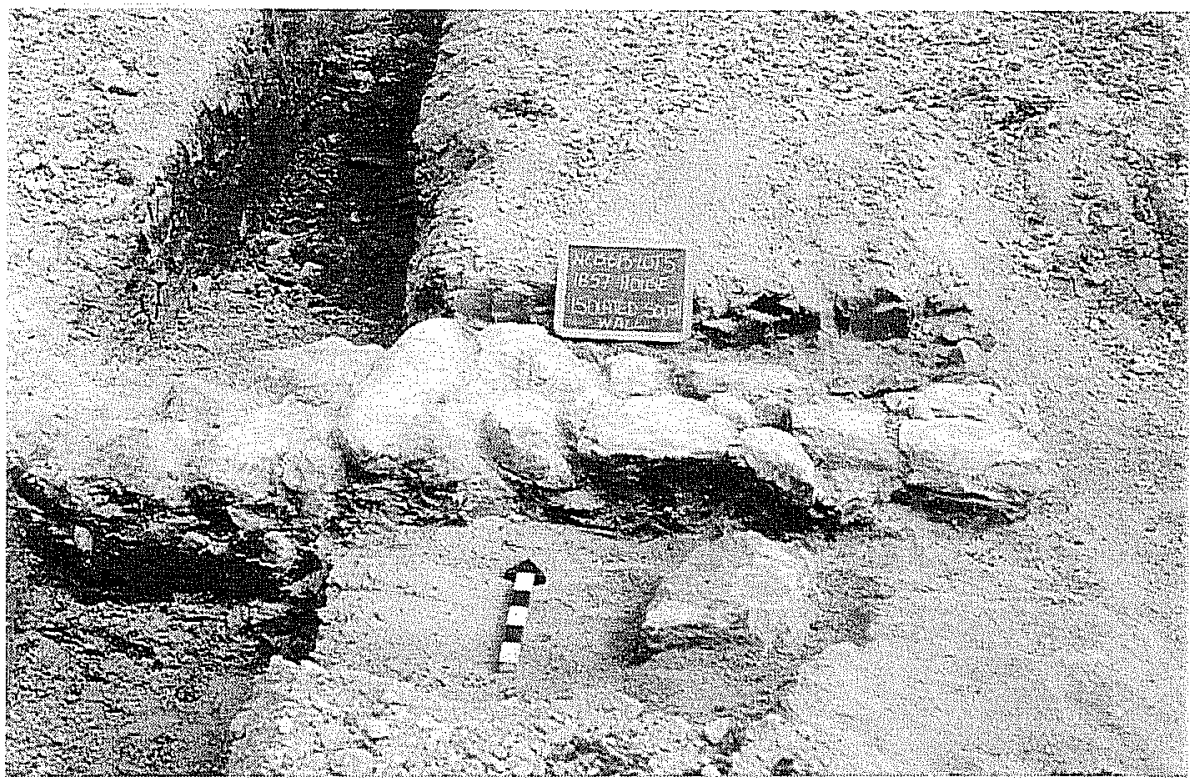

Figure 4-32. 41BX891, isolated south wall of original dwelling. west property lines.

\section{Trench A}

This trench measured approximately $2 \times 118 \mathrm{ft}$ and had one small break about $36 \mathrm{ft}$ south due to a large, industrial, concrete pier. Two features were encountered within this trench. Feature A was a large midden deposit composed primarily of alcoholic beverage glass ( 80 percent), ceramics (10 percent), and metal (10 percent). This feature was located $86 \mathrm{ft}$ south within the trench (Figure 4-33), just across the property line to the east from Feature A (cedar-postlined privy) on 41BX890.

Five 2-x-2-ft hand excavated test units were placed to further expose this feature. Two of the units were placed within the original backhoe cut, and three units ran to the west from the west side of the backhoe cut. The feature appeared to be roughly oval in shape, approximately $6.2 \mathrm{ft}$ east/west by $2.6 \mathrm{ft}$ at the center north/south. The pit in which the artifacts were deposited appeared to be a simple, unlined, earthen vault. In cross section the pit was slightly lens-shaped, flat on top at a depth of 11 inches below the ground surface, and convex on the underside reaching a maximum depth of 32 inches near the center of the deposit (21 inches maximum thickness). Almost all the glass deposited within the pit was broken, only three or four whole specimens were present out of literally hundreds of total bottles represented.

Feature $\mathrm{C}$ was also located within Trench $\mathrm{A}$, at $62 \mathrm{ft}$ south in the cut, in the east profile. Excavation

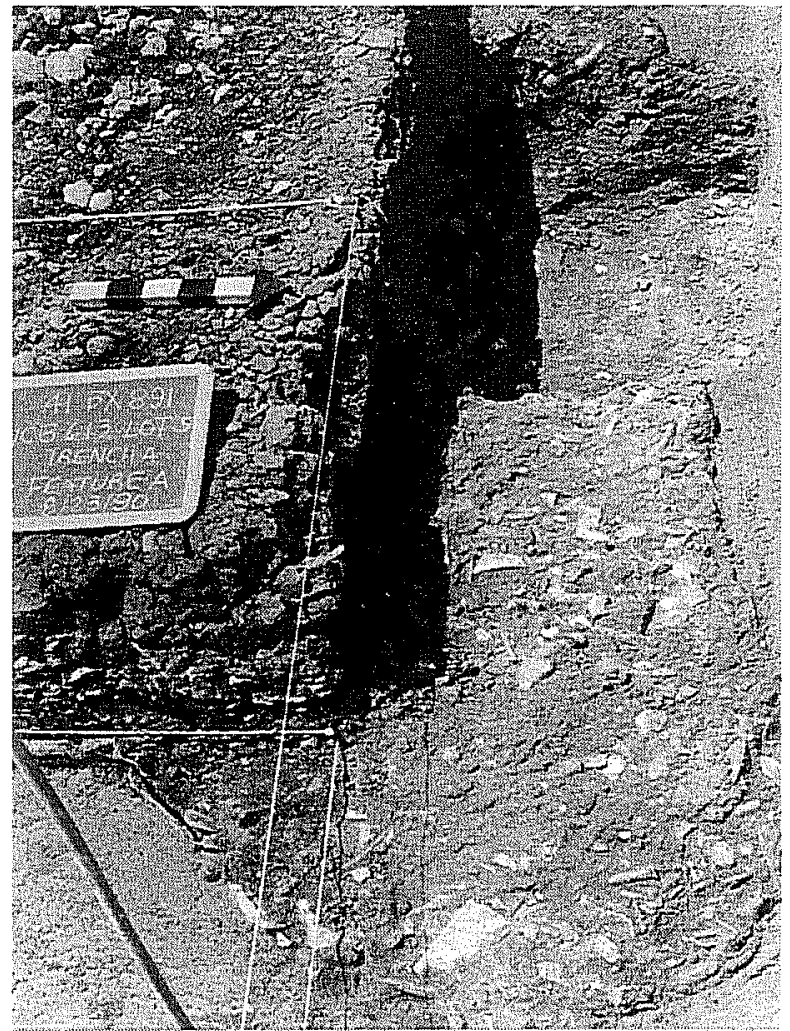

Figure 4-33. 41BX891, Feature A, midden deposit. 
revealed a small deposit of undecorated whiteware, nails, metal, and bottle fragments deposited within a very shallow lens (about two inches thick) overlain by a compacted charcoal ash layer approximately two inches thick. No other artifacts were present other than a tested chert core located at a depth of 25 inches below the surface. The artifact deposit was not placed in an obvious excavated pit and perhaps represents trash thrown into and burned in a convenient depression next to the property line.

\section{Trench B}

This trench was placed five feet inside the east boundary line of Lot 5 , running north/south. The north end was located about $27 \mathrm{ft}$ south of Wyoming Street. This put the north end of the trench actually inside the rear section of the primary dwelling. The trench was run parallel to the east boundary line for a distance of $100 \mathrm{ft}$. The extended south wall of the primary dwelling was contacted about $19 \mathrm{ft}$ south in the trench. A large cedar post was present in the west profile at $45 \mathrm{ft}$ south and Feature B was found at approximately $90 \mathrm{ft}$ south.

Feature B was an undefined, light-density artifact scatter (undecorated whiteware, bottle fragments, a buggy part, a mule shoe, and several bone fragments). This feature would have occupied the southeast corner of Lot 5 . It may be associated with several features located just to the east across the lot boundary on Lot 6 (41BX892). This section of the lot appears to have had much activity over time and debris deposited along one lot boundary could have spread to the other side over time. This is discussed further in the section dealing with 41BX892.

\section{Artifact Group Distribution and Comments}

The formation processes on this site were identical to those exhibited on 41BX890 and 41BX892. Problems involved in the quantification of massive amounts of bottle glass recovered from a single trash disposal feature on this site led to its being discarded from the list of sites used in the intersite comparisons of this study.

\section{BX892 - NCB 613, Lot 6}

Testing operations on 41BX892, NCB 613, Lot 6, 132 Wyoming Street, were carried out between August 8 and August 27, 1990. This was one of the three lots $(4,5$, and 6$)$ on NCB 613 north that was examined in a single operation (Figure 4-29). The documented history of this lot is slightly more complex than those of Lots 4 and 5 due to the fact that in a later platting, Lot 6 was further subdivided into two smaller lots: A-13 and A-14. Lot 6 (A-13) fronted on Plum/ Hoefgen Street (215) and Lot 6 (A-14) fronted on Wyoming Street as the corner lot (132).

The first dwelling built on the lot was constructed in 1855 by Jacob Rilling, for whom the site is named. This dwelling was located at 132 Wyoming Street and is visible on the 1904 Sanborn map as an adobe home (BCDR G2:144). At the time of construction the lot was still intact. In 1890 the southern half of Lot 6 was sold to a Charles D. Hogan who constructed a pierand-beam, Victorian-style home (215) fronting on the then Plum Street on this part of the lot (BCDR 91:123).

The earliest Sanborn map (1904) of the area shows the lot already subdivided (Figure 4-27). The northern part of the lot contained the adobe house built by Rilling and a large carriage house at the back of the subdivided A-14. The dwelling constructed by Hogan is shown on Lot A-13 and two small outbuildings occupy the northwest corner of the lot.

By the 1911 Samborn map, the north half (A-14) had changed significantly. Although the original dwelling was still present, three small shops fronting on Plum Street had been built. The large carriage house had either been modified or replaced by a series of smaller outbuildings. On the southern half of Lot 6 (A-13), the original dwelling was still present with minor modifications, and the area which previously contained the two small outbuildings now only shows one.

By 1952 the Lewis Equipment Company covered the whole lot with the exception of The Corner Cafe. The latter occupied 532 Wyoming, the northeast corner of the lot (Figure 4-26). 


\section{Excavations}

When testing was done on 41BX892, no buildings were present on the block. The industrial building belonging to Alamo Iron Works (formerly Lewis Equipment Company) which had been present up until 1990 had been torn down. The concrete padding was taken up by bulldozers, revealing a layer of caliche fill, 8-12 inches thick, over the entire block.

The datum point (elevation $655.23 \mathrm{ft}$ amsl) was the same as that used for the excavations on Lots 4 and 5 (41BX890, 41BX891). This was located $14 \mathrm{ft}$ west of the southwest corner of Wyoming and Hoefgen streets.

Testing for the remnants of the primary dwelling on the north side of Lot 6 (A-14) revealed a limestone foundation approximately 13 inches below the existing ground surface. The foundation, fully exposed by the backhoe, was composed of broken limestone chunks set in mortar (Figure 4-34). No living surfaces were present and the surface had apparently been cut down to a point where only about 18 inches of the foundation remained vertically. The foundation, when completely uncovered, was an accurate representation of what was pictured on the 1904 Sanborn map (Figure 4-27). Only a small section of the southeast corner was not present. The residence was a rough $L$-shape, with the long axis facing Hoefgen Street. Dimensions were as follows: east wall $30 \mathrm{ft}$, north wall $19 \mathrm{ft}$, south wall $11 \mathrm{ft}$, thence north $12 \mathrm{ft}$, thence west $8 \mathrm{ft}$, west wall $18 \mathrm{ft}$. No interior dividing walls were present. in a southerly direction. Three features were found in the initial backhoe cut.

\section{Feature A}

Located between 56 and $62 \mathrm{ft}$ south, Feature A was almost certainly the remains of an earthen vault privy. Many different classes of artifacts and the remains of two wooden crates stacked on top of each other were found deposited under a light clay matrix (Figure 4-35). Three hand-dug 2-x-2-ft units were placed within the existing backhoe trench to further examine this feature. Within the center unit, excavations continued to a depth of 56 inches, cultural material was encountered to this depth. It appeared that the feature continued in the west profile, and a cedar post revealed near the east side of the trench was probably associated with the superstructure of this feature. Among the artifacts recovered were intact newspaper fragments written in both English and German (If the German newspaper fragments were from the German language newspaper San Antonio Zietung, this would make the fragments over 130 years old). The interior stratigraphy of the deposits exhibited a "slumping" appearance that was noted in other privy pits across the site area.

\section{Feature B}

Feature B was located $112 \mathrm{ft}$ south of Wyoming Street in Trench A and was an area of discolored soil, apparently manure. Several horseshoes, undecorated whiteware, and stoneware fragments were found in light density with little depth below the caliche-fill

Two backhoe trenches were placed across the lot in accordance with the strategy stated at the beginning of the section.

\section{Trench A}

This trench was placed five feet east of the reconstructed boundary line between Lots 5 and 6 . The north end of the trench was $30 \mathrm{ft}$ south of the south side of Wyoming Street and continued $100 \mathrm{ft}$

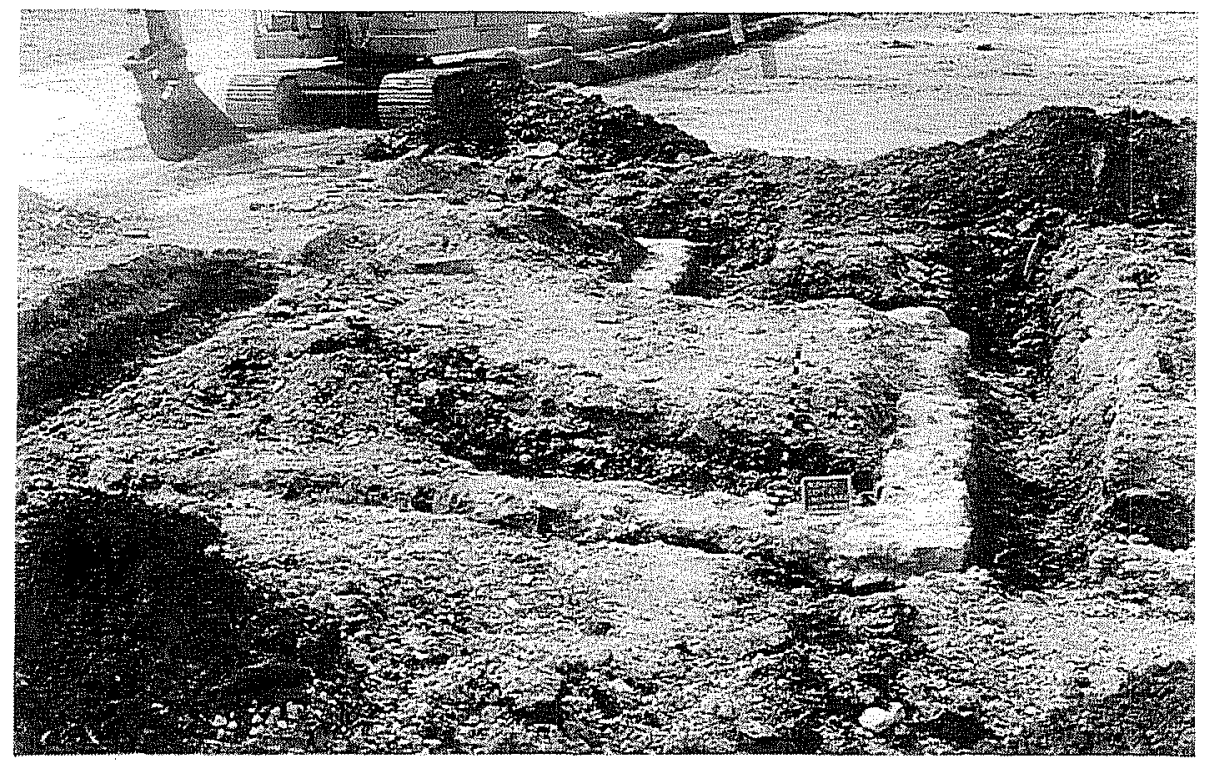

Figure 4-34. 41BX891, foundation of original dwelling. 


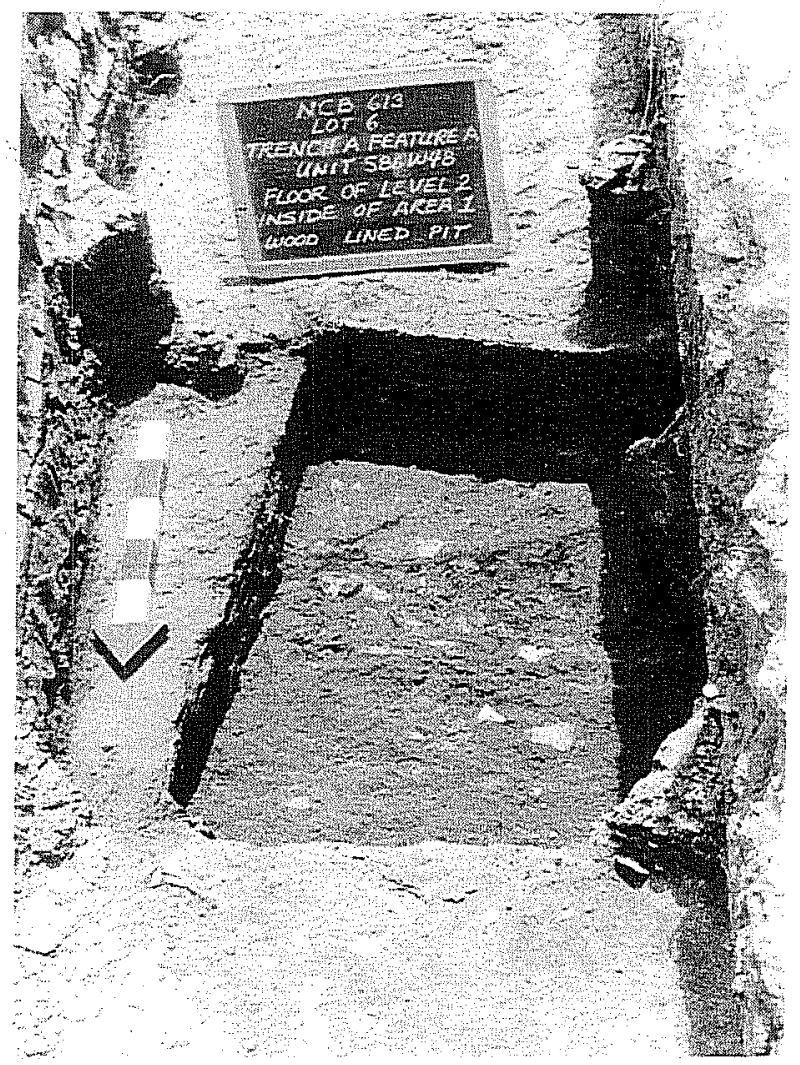

Figure 4-35. 41BX891, Feature A, earthenvault privy.

zone. This area may have been associated with the northwest corner outbuildings indicated for 215 Plum Street and functioned as a stable or tack area. been used for disposal of food refuse and kitchen/ domestic items. Two cedar posts were located west of this trash pit near the property line. These posts may be associated with a small outbuilding pictured on the 1911 Sanborn map as being on Lot 5 (41BX891). No direct association of these posts with the trash feature was made.

\section{Trench A Extension}

The presence of several yellow Laredo-style bricks at the south end of Trench A led to the decision to extend Trench A at this point into a wider test. Two features were revealed in this test and they were labeled separately from the other features in Trench A.

\section{Trench A Extension/Feature A}

The yellow bricks turned out to be associated with a brick-vaulted privy located $120 \mathrm{ft}$ south of Wyoming Street and $62 \mathrm{ft}$ west of Hoefgen Street (Figure 4-36). This location is in association with one of the two small structures pictured in the 1904 Sanborn map as having been located on Lot 6 (A-13) owned by Mr. Hogan. Although many of the privies examined during the course of this project showed signs of outside stress from the soil, this was the only privy that exhibited total structural failure due to the pressure. Both the east and west walls of the privy had collapsed inward and the north and south walls were inclined inward at

\section{Feature $\mathrm{C}$}

Located $72 \mathrm{ft}$ south of Wyoming Street in Trench A, Feature $\mathrm{C}$ was a very dense, circular trash midden, measuring three feet in diameter and 14 inches deep. The feature was contacted 24 inches below the ground surface. Most of the artifacts-ceramics, bone fragments, metal plate, lamp parts, and wood burning stove parts-appeared to be derived from a domestic context. The location, shape, and context suggest a deliberately excavated trash pit associated with the structure at 132 Wyoming Street. The pit would have

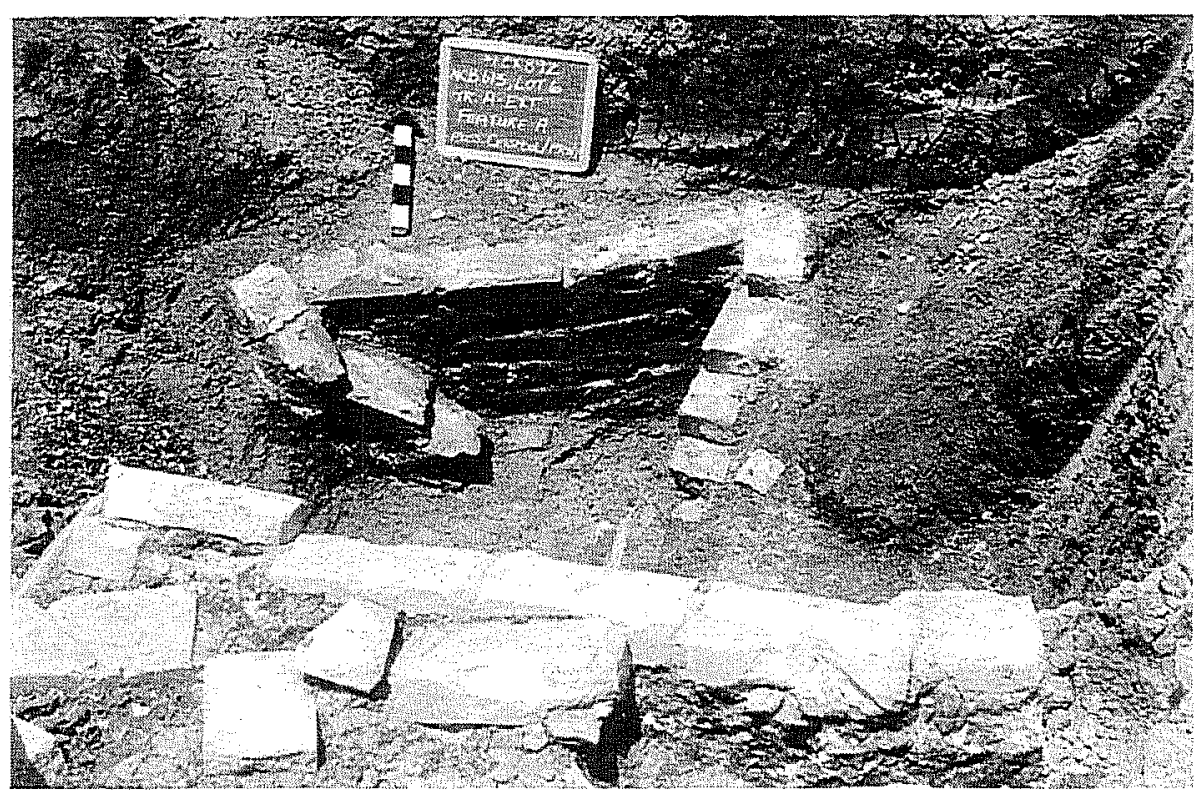

Figure 436. 41BX892, Trench A extension, Feature A, brick-lined privy vault. 
steep angles. The privy was exposed, mapped, and sampled; however, it was not tested for depth. A cedar post was uncovered to the west of the brick vault. The post was probably associated with a superstructure covering the privy vault. Based on the yellow bricks, which were brought into San Antonio by rail, the privy dates to post-1877.

Trench A Extension/Feature B

This feature was located directly east of Feature A. It was a small area, approximately $4 \times 4 \mathrm{ft}$, with a light scatter of glass and metal scrap. The feature appeared to have little depth and no uniform shape. Most of the artifacts appeared to be more contemporary than those coming from the interior of Feature $\mathrm{A}$. This feature may represent a scatter resulting from the covering of Feature $A$ and the razing of its surrounding structure.

\section{Trench B}

This trench was placed in a direct north/south line with the east wall of the adobe structure on Lot A-14. The north end was immediately south of the southeast corner of the structure (56 ft south of Wyoming Street, $14 \mathrm{ft}$ west of Hoefgen Street). The trench ran north/south for a distance of $76 \mathrm{ft}$. Although soil horizons appeared to be the same as those displayed in the other trenches across NCB 613, this trench revealed no cultural features and no artifacts. It is possible that more deeply laid features-such as wells and privies-were never placed this close to the edge of Plum/Hoefgen Street. Several small commercial shops show on the 1911 Sanborn map, and the east end of a carriage house appears on the 1904 Sanborn map in this area. Due to the industrial impact on the lot, no stratigraphic evidence for the presence of any of these structures was observed.

\section{Phase III Trash Pit}

During Phase III demolition monitoring for the Alamodome footprint area, an additional feature was recorded for NCB 613, Lot 6 (A-13). Approximately $22 \mathrm{ft}$ south of the location of the brick-vaulted privy (Trench A extension/Feature A), a very large trash pit was revealed. The center of the trash pit was estimated to be approximately 150 south of Wyoming Street and $64 \mathrm{ft}$ west of Hoefgen Street. The deposit was in a well-defined earthen pit, circular in form, about $10 \mathrm{ft}$ in diameter, and at least three feet deep. Bottle glass was virtually the only component of this trash pit.

\section{Artifact Group Distribution and Comments}

Since this site rested below the asphalt surface, most of the excavations were initially done by backhoe. Living surfaces and sheet refuse were not present. Table 4-9 shows the artifact group percentages derived from excavations on this site.

Table 4-9. Site Artifact Frequency Distributions for $41 B X 892$

\begin{tabular}{|c|c|c|c|}
\hline Group & $\#$ & $\overline{\%}$ & Notes \\
\hline Activity & 96 & 6.76 & 38 wire frags. \\
\hline Architecture & 474 & 33.38 & 362 wire nails \\
\hline Arms & 0 & 0.00 & \\
\hline Bone & 216 & 15.21 & \\
\hline Clothing & 8 & 0.56 & 7 buttons \\
\hline Furniture & 21 & 1.48 & 16 lamp parts \\
\hline Kitchen & 588 & 41.41 & 398 bottle glass \\
\hline Personal & 17 & 1.20 & 10 mirror glass \\
\hline Total: & 1,420 & 100 & \\
\hline
\end{tabular}




\section{$41 B \times 893$ - NCB 615, Lot 7}

Archaeological testing was performed at NCB 615, Lot 7, 724 Wyoming Street between August 17 and September 10, 1990 (Figure 4-37). This was an irregularly shaped lot which, at the time of testing, measured $67 \mathrm{ft}$ wide on the north side. At $109 \mathrm{ft}$ south, the lot narrowed down to $46 \mathrm{ft}$ wide. Total length for the lot was about $200 \mathrm{ft}$.

In 1890 Julian Czernecki, a Polish immigrant (for whom the site is named) purchased Lots 7 and 8 of NCB 615 and built a residence at 724 Wyoming Street (BCDR 63:453). The 1904 Sanborn map shows both Lots 7 and 8 as a single unit. The Czernecki residence is present on Lot 7, and two small outbuildings are shown to the south of the primary dwelling. By 1911 the lot has been divided and three dwellings have been constructed on Lot 8 facing onto Cherry Street. These were rental houses constructed by Czernecki. Lot 7 shows a diagonal narrowing along its middle, on the east boundary. The primary dwelling is basically the same with only minor modifications showing on the south side. One outbuilding is still present to the south of the primary dwelling and a very small outbuilding is pictured near the center of the lot along the east boundary of Lot 7. By 1952 the lot appears much as it did when testing started in 1990 . A secondary dwelling has been constructed behind the primary dwelling, with an attached garage annex. A small outbuildingnot present in 1990-was located along the east boundary of the lot near the center. The east boundary line for Lot 7, which narrowed diagonally in the 1911 Sanborn map, is narrowed in a square $\left(90^{\circ}\right.$ angle) fashion in the 1952 Sanborn map (Figure 4-38).

\section{Excavations (Figure 4-39)}

When excavations started on 41BX893, the primary dwelling had been subdivided into three separate apartments on the inside. Shortly after the structure was abandoned an arson fire completely gutted the building. The Carpenter Gothic trim that had graced the columns on the front of the house had also been stolen.

A site datum (elevation $659.69 \mathrm{ft}$ amsl) was placed at the northeast corner of Lot 7 . Thirty 2-x-2-ft test units were placed across the lot. The units were put in areas that the Sanborn maps indicated might contain activity areas, as well as randomly selected areas of the lot. In

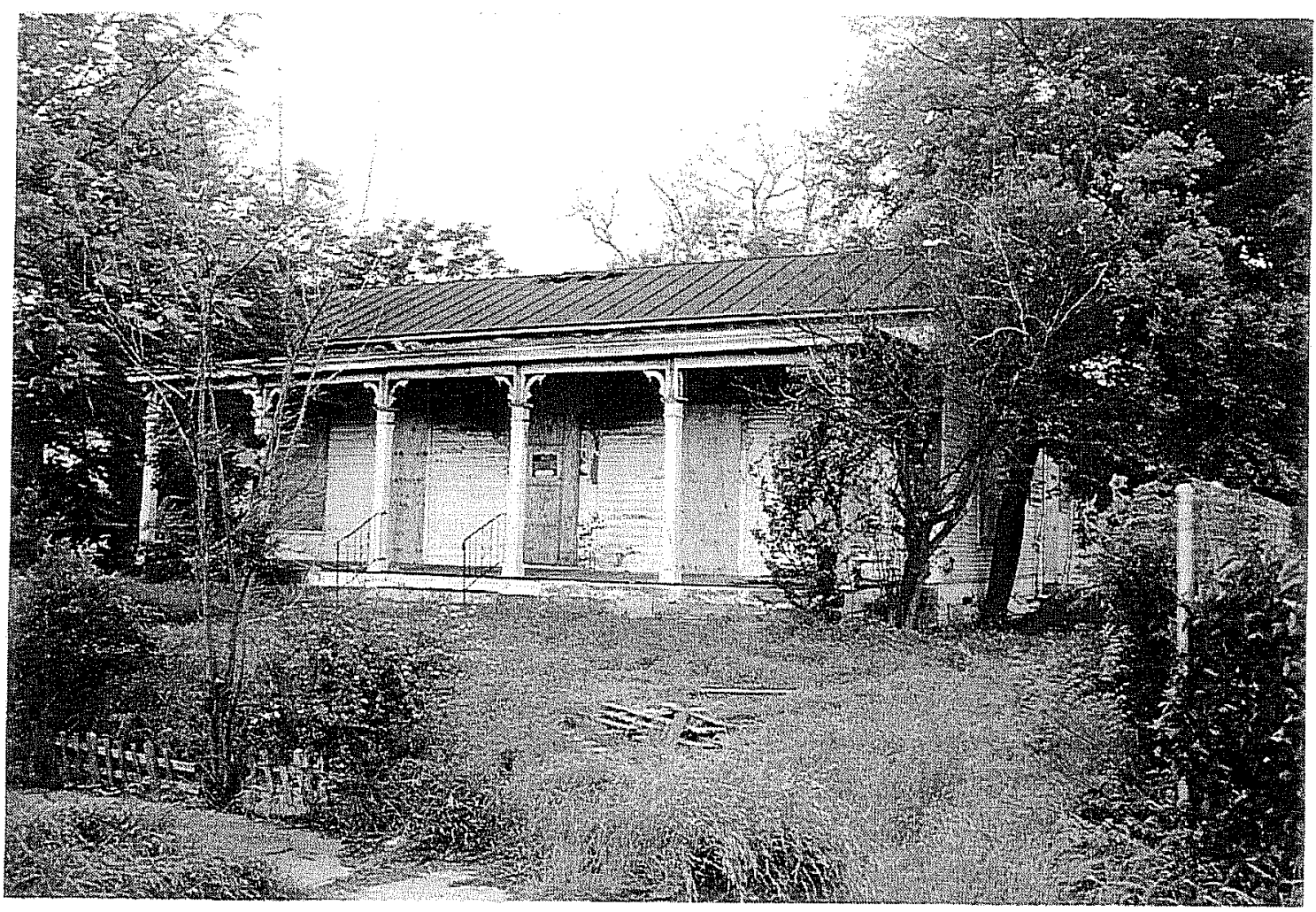

Figure 4-37. The Czernecki house, 1990. 


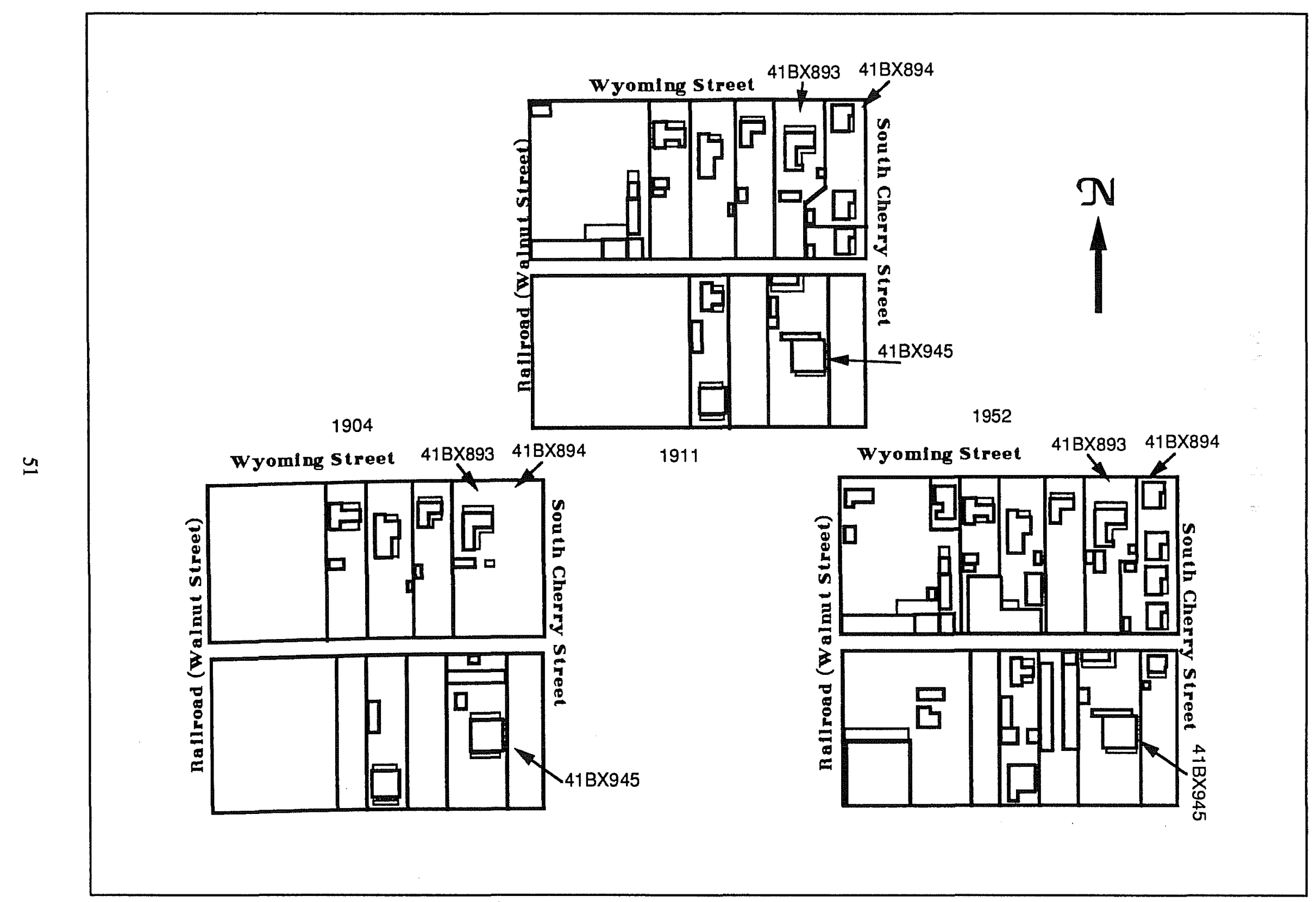

Figure 4-38. NCB 615. Adapted from Sanborn maps. 


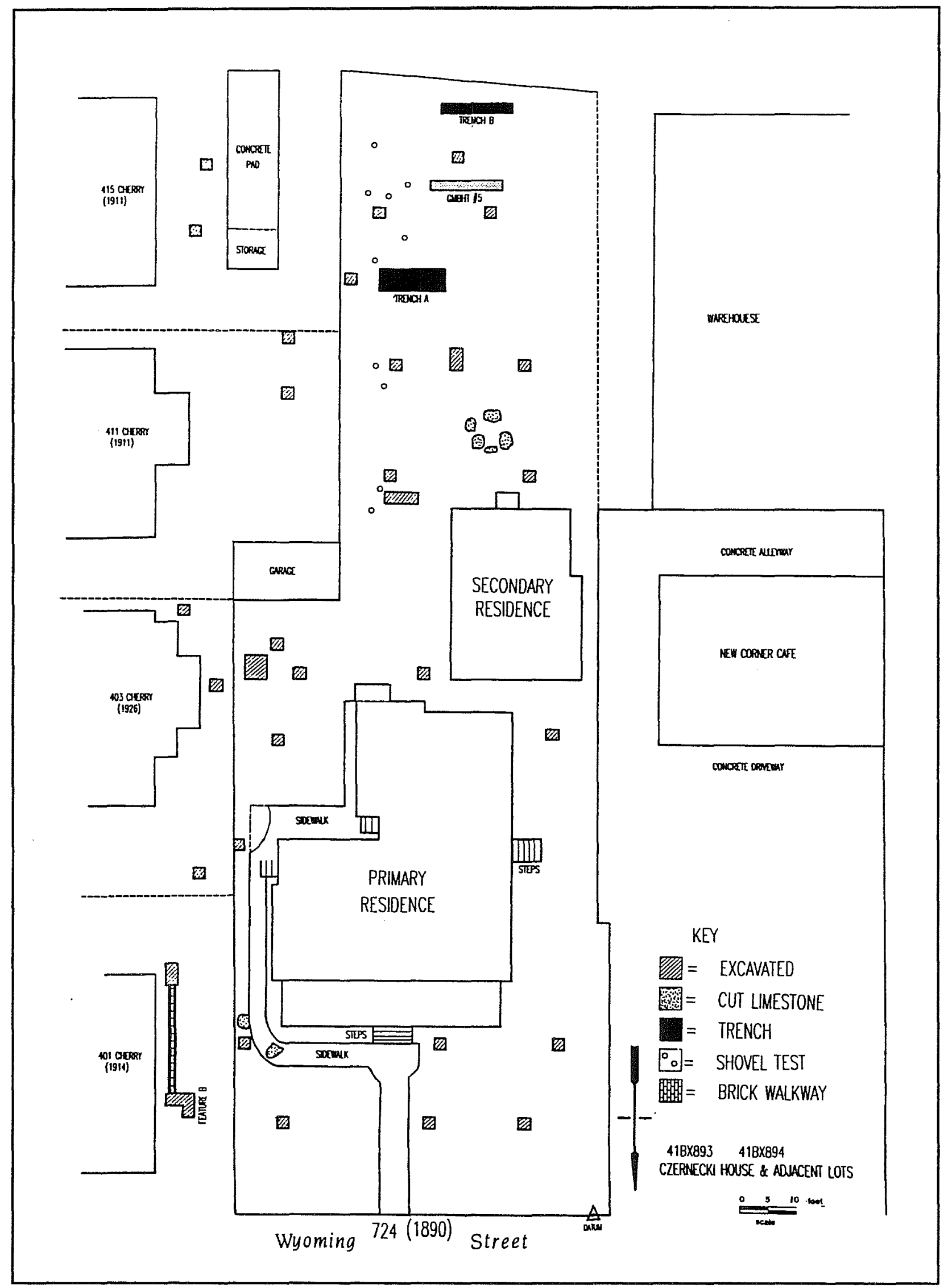

Figure 4-39. 41BX893 and 41BX894, site maps. 
addition, two standard backhoe trenches and one geomorphic backhoe trench were initiated on the southern half of the lot. A small metal detector survey was also conducted on the site.

Two noticeable stratigraphic features became apparent as work proceeded across the site. The lot appeared to have had from 2-6 inches of a fine caliche fill dirt spread over much of the surface before the foundations of the primary dwelling were laid (primarily on the north end of the lot). Perhaps this was to level the lot before construction. The site had been significantly affected by adjacent industrial activity. Up until 1969 the lots located directly to the west (Lots 4 and 5) had housed the Acme Brass Foundry. In 1969 this burned and was replaced by the Mitchell Metal Warehouse on Lots 4, 5, and the southern half of Lot 6 . Just across Pauly Alley to the southwest (Lot 14) was the U.S. Heat Treating Company which worked primarily on oil field equipment.

The most notable effect of the adjacent industrial activity was the presence of large quantities of metal slag, metallic ash, dust, small metal scraps, welding rod fragments, wire, and other industrial refuse. Although this disturbance was site-wide (found in 14 out of 30 excavation units), it was heaviest in the units from S84-S187. The only areas not containing significant quantities of this deposit were those located immediately southeast of the primary dwelling, just north of where the lot narrows.

Only one feature was designated for the site. This was located within the area where the 1911 and 1952 Sanborn maps had indicated the presence of a small outbuilding. A heavy concentration of caliche soils mixed with metal pipe fragments and wire nails (many resting in a vertical position) were encountered. A very decomposed pipeline of wrap (early) construction was located running north/south in unit S83/E55. Using a metal detector, we traced the pipeline to a point two feet to the south of the exposed area's northwest corner.

We found no direct evidence to verify the existence of any of the outbuildings that had been located in the far south yard.

\section{Trench A}

Trench A ( $4 \times 12 \times 3 \mathrm{ft}$ ) was placed to examine an area that appeared on the 1904 and 1911 Sanborn maps to have been occupied by an outbuilding. No structural remains were found. A small trash deposit was found in units S150E23 and S152E23. Metal, clinker, undecorated whiteware, glass fragments, and the remains of a metal bucket-containing the other items and quite a bit of ash-were located here.

\section{Trench B}

Trench B $(2 \times 13 \times 2 \mathrm{ft})$ was located at the extreme south end of the lot just north of Pauly Alley. The stratigraphy of this trench indicated that Pauly Alley had never been wider to the north than it presently was. The absence of the caliche fill-zone on this portion of the lot indicates that no leveling was carried out this far south on the lot.

\section{Geomorphic Trench 5}

One of six geomorphic trenches placed across the Alamodome construction area was placed on this site. This trench was located $182 \mathrm{ft}$ south of Wyoming Street and measured $2 \times 13 \times 7.3 \mathrm{ft}(225 \mathrm{~cm})$. The trench was cut in $25-\mathrm{cm}$ levels. The results of this work are given in Appendix C.

Several large, cut limestone blocks were present on the surface of the lot. Two were located just off the northeast corner of the primary dwelling, one of which was situated in the center of a concrete walkway. Five others were located just south of the secondary dwelling and were situated in a roughly circular pattern. Evidence of fire was found in the center of the circle of stones. One of the closest possible sources for the stones could have been from the ruins of the Pauly house (41BX945) located across the alley to the south. There was a tie by marriage between the Czernecki family and the Mueller family who owned the Pauly lot after 1898; therefore, the Czernecki family would have had easy access to this part of the block. 


\section{Artifact Group Distribution and Comments}

Table 4-10 shows the artifact group percentages for the site. As previously mentioned, this site was affected by adjacent industrial activity, which contributed to artifact groups such as activity and architecture. The fact that an informal alleyway ran across the south end of the lot also affected the artifact deposition on that side of the lot. The accumulation of artifacts around the edges of this alley was similar to artifact accumulations around the edges of trails on vacant lots as described by Wilk and Schiffer (1979). Figure 4-40 shows the artifact frequencies occurring across the lot. The back portion of the lot has a much higher density of artifact occurrence than the front portion, with the heaviest density adjacent to the alleyway.

Table 4-10. Site Artifact Frequency Distributions for 41BX893

\begin{tabular}{||l|c|r|l||}
\hline \multicolumn{1}{|c|}{ Group } & \multicolumn{1}{c|}{$\#$} & \multicolumn{1}{c|}{$\%$} & \multicolumn{1}{c|}{ Notes } \\
\hline Activity & \multicolumn{1}{c|}{438} & 9.53 & 148 wire; 62 misc. metal \\
\hline Architecture & 1,657 & 36.07 & 1,090 wire nails \\
\hline Arms & 10 & 0.22 & 9 cartridges \\
\hline Bone & 805 & 17.52 & \\
\hline Clothing & \multicolumn{1}{c|}{36} & 0.78 & 14 buttons \\
\hline Furniture & 6 & 0.13 & 5 light bulb frags. \\
\hline Kitchen & 1,615 & 35.15 & 1,408 bottle glass \\
\hline Personal & 27 & 0.59 & 11 slate frags; 7 coins \\
\hline \multicolumn{1}{|r|}{ Total: } & $\mathbf{4 , 5 9 4}$ & $\mathbf{1 0 0}$ & \\
\hline
\end{tabular}

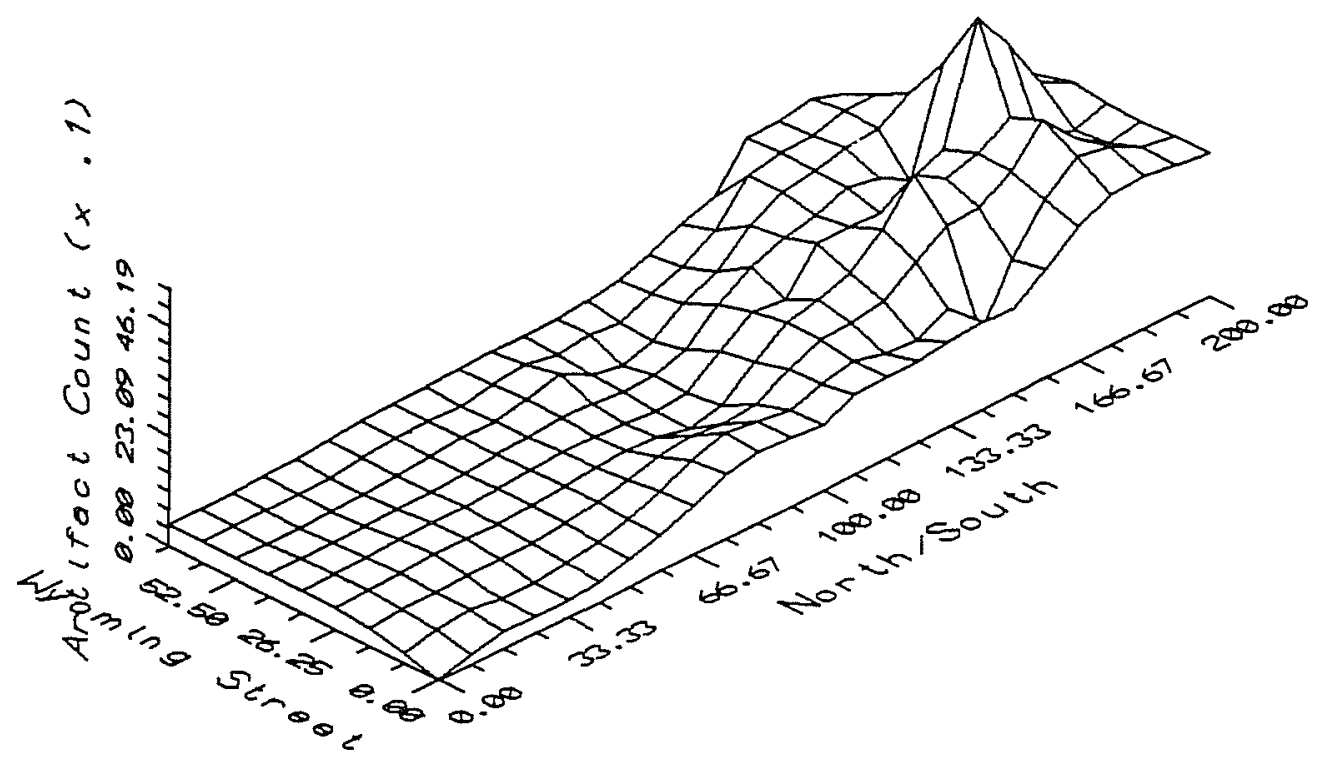

Figure 4-40. 41BX893, spatial frequency of artifacts across the site. 


\section{BX895 - NCB 628, Lots 1 and 2}

Known as the Garza Store site, $41 \mathrm{BX} 895$ measures $65 \times 100 \mathrm{ft}$ and is located on NCB 628, Lots 1 and 2, 602 Hoefgen (Figure 4-41). The site represents one of the first commercial developments within the area. Albert Weiss developed a bluing manufacturing plant/residence on the property in 1888 (BCDR 67: 182; CD 1887-1888). The plant was converted into a grocery store/residence in 1891 (CD 1896-1897). The site is named after the last residents of the

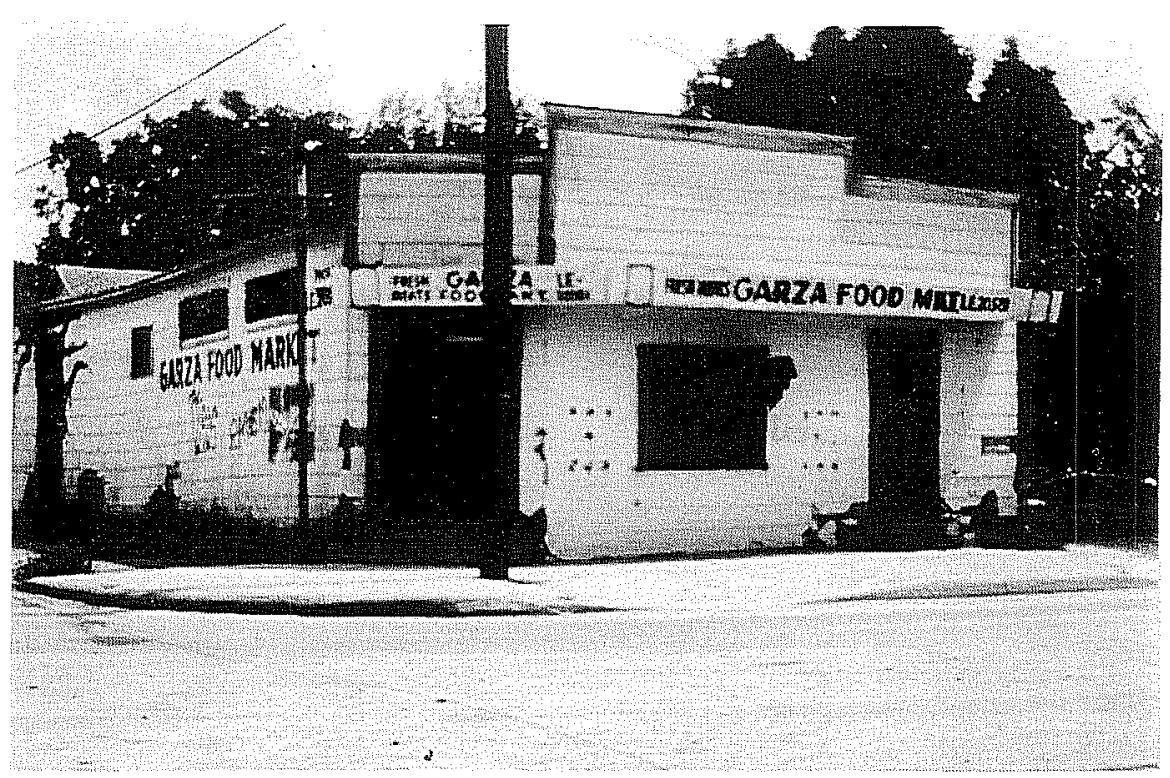

Figure 4-41. The Garza Store, 1990. property, Alphonso and Mary Garza, who acquired the property in 1946 and ran the small store until the area was abandoned for the construction of the Alamodome (Figures 4-42-4-44).

The 1904 Sanborn map (Figure 4-45) shows the grocery store occupying almost the entire north end of Lot 1 and northwest Lot 2 . The primary residence which is attached to the store extends south from the store. A secondary, square-shaped dwelling is located

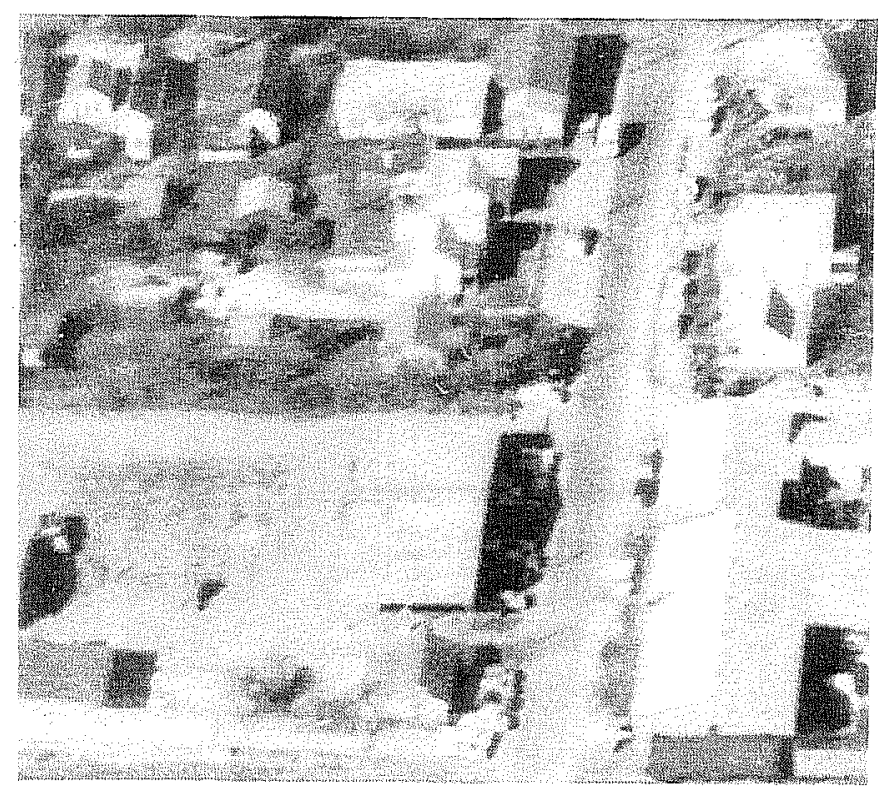

Figure 4-42. NCB 628, ca. 1955. Facing west. Rear of the Garza store is at the top center of the photograph.

in the southwest corner of Lot 1. The 1911 map is virtually identical to the 1904 map, with the exception of minor modifications to the south end of the primary dwelling. Around 1952 the Garza family removed the old primary dwelling and constructed a new larger residence in the same location. The 1952 Sanborn map reflects this change, as well as the absence of the secondary dwelling which had been located in the southwest corner of the lot. The larger residence, although close, is no longer directly attached to the grocery store (Figure 4-45).

\section{Excavations (Figure 4-46)}

At the time testing was started within the project area, the Garza store complex was still intact. However before the field crew arrived to start testing on this particular site, the 1952 residence which had covered a large portion of the surface area of Lot 1 had been removed (Figure 4-44). From September 13-18, 1990, Phase II testing was performed on the Garza store lots, designated 41BX895. Additional work was also done on this site from February 11-13, 1991.

Once the 1952 primary dwelling had been removed, the supporting elements for the structure were visible. The house had been supported by concrete piers which had run around the outside perimeter of the 


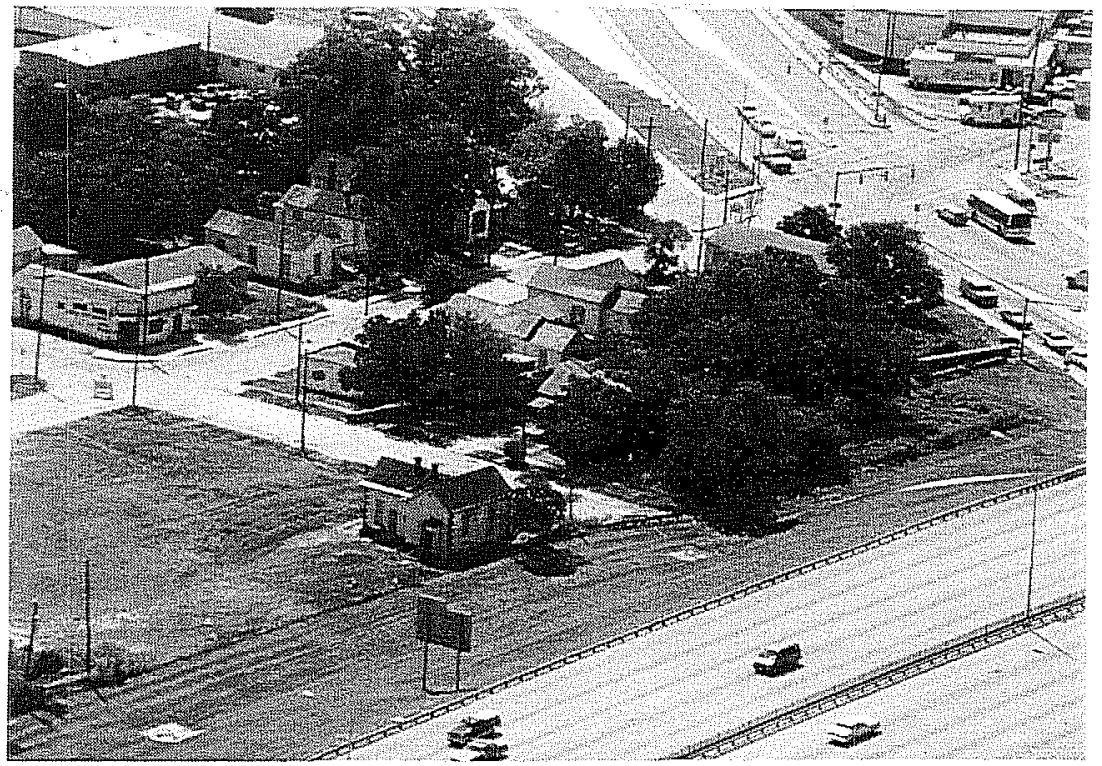

Figure 4-43. Garza Store (left), before house removed. Facing southeast.

structure. An additional north/south line of concrete piers ran down the center line of the structure.

Also present beneath the area where the house had rested were structural elements associated with the earlier, smaller primary dwelling. Several lines of cedar posts were arrayed inside the area where the concrete piers were laid. The cedar posts outline a smaller structure which matched the size of the dwelling shown on the 1904 and 1911 Sanborn maps (approximately $20 \times 35 \mathrm{ft}$ ). Also present was a very visible area of packed earth measuring $4 \times 11 \mathrm{ft}$ which was just west of where the smaller structure would have been located. This may represent an entry-way into the smaller structure.

Fourteen 2-x-2-ft test units (Figure 4-46) were placed running north and east of a baseline established from a datum point (elevation $649.63 \mathrm{ft} \mathrm{amsl}$ ) located on the east side of Hoefgen Street, $100 \mathrm{ft}$ south of the southeast corner of Hoefgen and Nevada streets. The units were placed to investigate three areas:

1) the area under the 1952 primary dwelling, yet outside the area occupied by the 1888 primary dwelling;

2) areas surrounding and just outside the area occupied by the 1952 primary dwelling;

3) the area occupied by the secondary dwelling pictured on the 1904 and 1911 Sanborn maps.

Three units (N35E35, N39E38, N51E43) were placed to examine the area near the front of the earlier 1888 primary dwelling. No features were encountered; however, varying layers of caliche soil suggested different episodes of fill were placed across the lot. Most of the artifacts appeared to be architectural in nature (window glass, nails, etc.).

Five units were placed just inside or around the periphery of where the 1952 primary dwelling had stood. These units revealed the presence of a hardpacked driveway in buried context just east of the store and residence. They also revealed a high occurrence of faunal material within the area between the store and the residence, in a small open space on the east side of the lot (N65E55, N73E55). The bones, primarily in

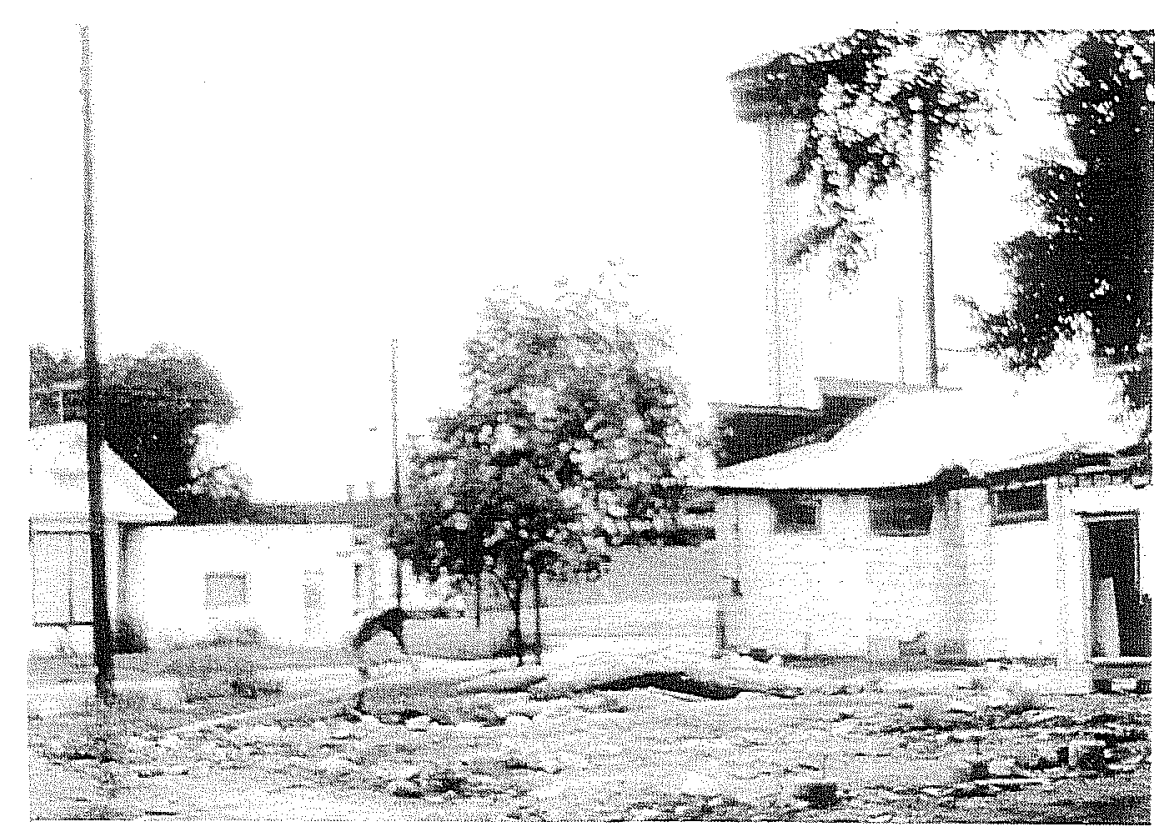

Figure 4-44. Garza Store (right), after house removal. 


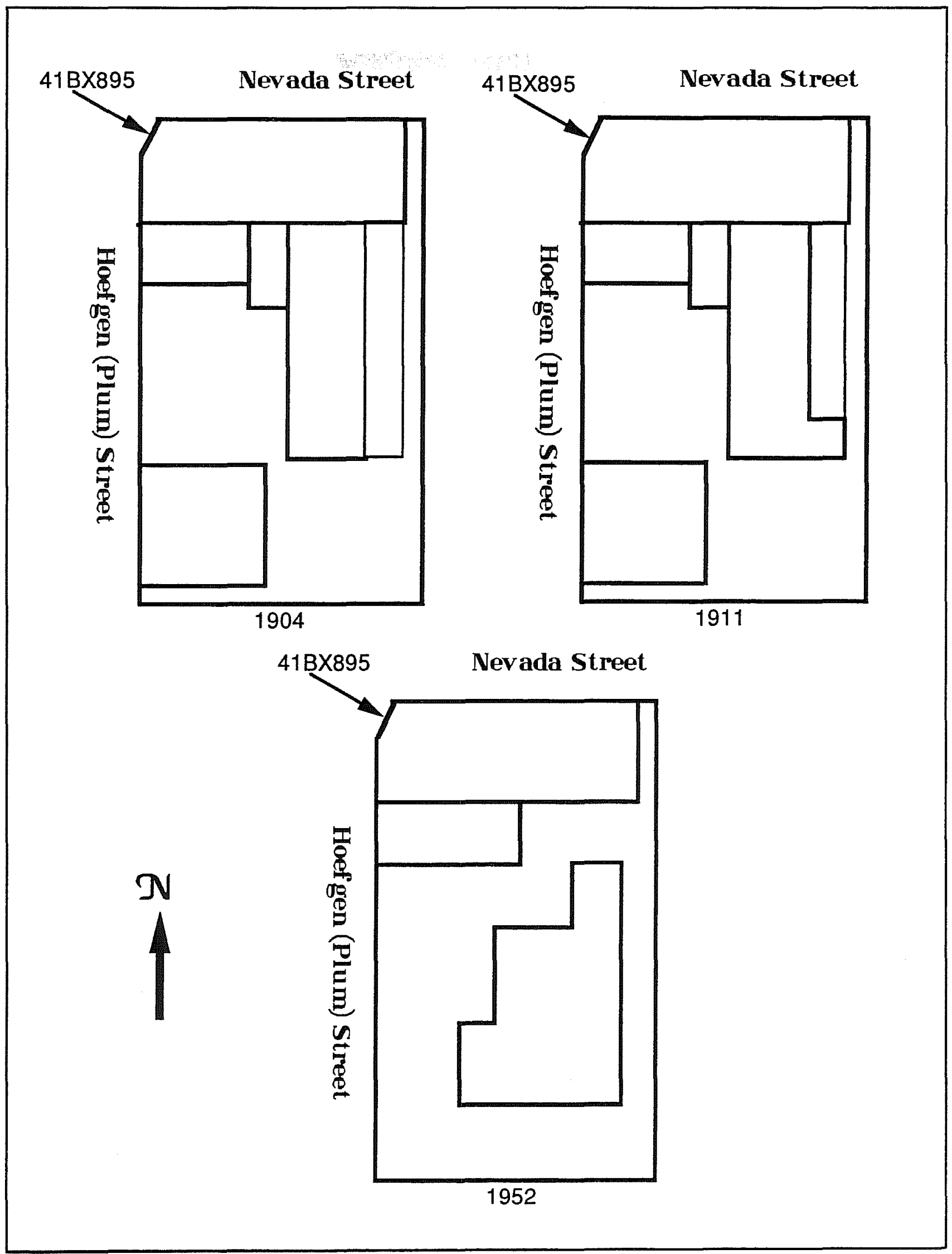

Figure 4-45. $N C B$ 628, northwest corner. Adapted from Sanborn maps. 


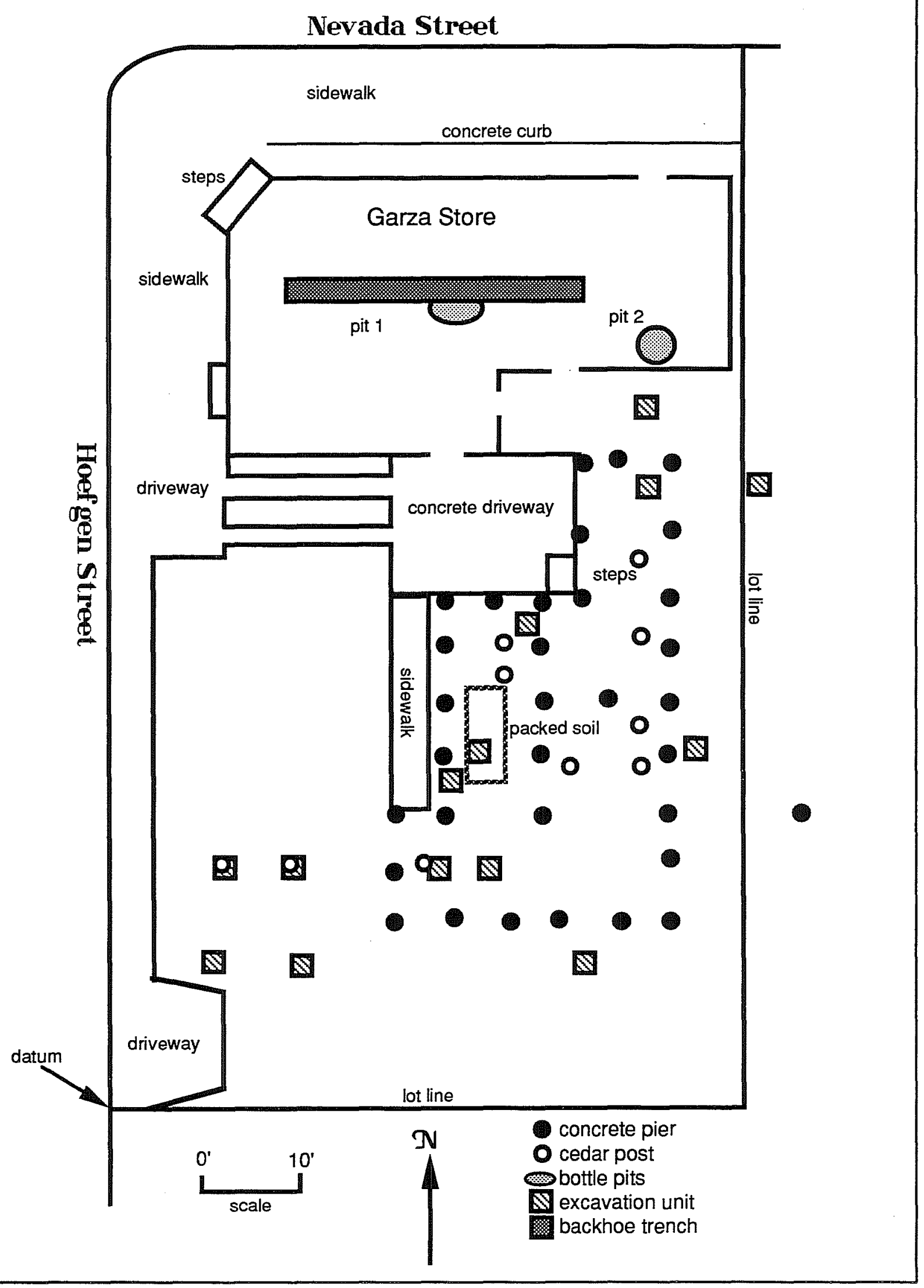

Figure 4-46. 41BX895, site map. 
very small fragments, were both cut and uncut. This area may have been an activity area for scavenging animals over time. Both dogs and cats were scavenging on the site at the time of testing; and the locality would have allowed animals the opportunity to eat with a relative degree of security (because the area was hemmed on two sides by the residence and the store which would have limited outside visibility, yet easy escapes or resting areas were present beneath the two structures). The area around the southeast corner of Lot 1 yielded artifacts of a more domestic nature (toys, buttons, ceramics). A vanilla extract bottle, which became of greater importance at a later date (see below), was also found.

Six test units were located to investigate the $20-\mathrm{x}-20-\mathrm{ft}$ secondary dwelling indicated on the 1904 and 1911 Sanborn maps. Three cedar posts representing the north side of this structure were revealed. Additionally, evidence was found that this structure had burned. Almost all the units excavated within this area yielded layers of charcoal from 9-12 inches below ground surface. Several other units, not directly associated with this structure but close by (N35E35, $\mathrm{N} 39 \mathrm{E} 38$ ), also yielded traces of charcoal at nine inches depth.

Most of the artifacts derived from this area of the site were architectural in nature and were found in high density. Most of the material recovered in the initial testing of this site was probably associated with the residential occupation of the site rather than with the commercial operations. The store which was present occupied the far north side of the lot. Plans were made to return to the site at the time that the grocery store section (which dated to the late 1880s) was to be removed, and to test below the floor area.

Much emphasis was placed on negotiations with the demolition contractors that, due to the historic nature of the building, archaeologists should be present when the building was removed and, if possible, it should be done in a fashion that would allow for as little disturbance below the floor of the structure as possible. At this point in the Alamodome construction process the front access gate to the construction was located only a few feet from where this structure was located. Large crowds of people seeking employment regularly congregated around the front of the abandoned store.
On February 11, 1991, the demolition monitoring crew became aware that the Garza store had been demolished by a bulldozer without prior notification to the archaeologists. It was reported that significant archaeological deposits were present below the floor surface of the store and that active looting of these deposits was being carried out by individuals present around the front gate of the construction area. An archaeological crew was immediately dispatched to the area and efforts-largely unsuccessful-were made to stop the looting.

Since the demolition of the store had been unmonitored, most of the superstructure of the store had been stacked over the top of what had been the south and east sections of the store. Thus several areas appeared to be relatively undisturbed. Surface examination of this area revealed the presence of two small pits containing hundreds of whole vanilla extract bottles. Other types of bottles, bone, coins, and various debris was scattered over the surface in general.

We decided to place a 30-ft backhoe trench down the midline of where the store had stood in an east/west orientation. This trench would intersect the north side of one of the bottle pits. Cultural material was present from 0-14 inches below the ground surface. The soil was composed of a homogenous dark grey clay. The only difference noted stratigraphically was that approximately 14 inches below ground surface, the soil became slightly more compacted and sterile. The largest deposit of coins $(n=23)$ found during the project was collected from this location. The coins range in date from 1901 to 1952 . Most of the coins and many of the other small artifacts were most likely lost through the floorboards of the store. Periodic sweeping of the interior wooden floor would insure a steady deposit of soil and small artifacts falling through to the ground surface below. The vanilla bottles, however, were intentionally cached below the edge of the store under the floor.

Once the rubble from the store was collected and hauled off of the site in trucks, a layer of caliche filldirt was deposited over the entire site, stopping the active looting which had been ongoing. The area was then used as a parking area for Alamodome construction personnel. 


\section{Artifact Group Distribution and Comments}

The dual nature of this site (residential/commercial) had a significant impact on the way in which artifacts were distributed over the area. Table 4-11 shows the overall artifact group percentages for the site. Figure 4-47, a percentage breakdown of the group distributions within the two distinct areas of the site, shows that the frequencies of artifact groups are quite different between the residence and the store. The residential part of the site on the south part of the lot was typical of many residences examined during the course of the project, with architectural artifacts being the most notable indicators of activity in the area. The commercial part of the site on the north end of the lot was best represented by the accumulation of debris beneath the floor of the store, with areas around the outside edges not showing a great deal of impact from the commercial activity occurring there. If the floor of the store had not been as loosely constructed as it was, then the commercial aspect of the site would have been more poorly represented (as at 41BX885).

A significant amount of abandonment-stage and defacto refuse indicative of commercial activity was inside the store at the time that investigations started. Paper items representative of the transactions carried out by the store and cheap items offered for sale were scattered throughout the interior.
Figure 4-48 shows the artifact spatial frequency of the site. This graph does not indicate the excavations carried out under the store, only the Phase II testing on the site. The most notable feature of the graph is the indication of a large activity zone on the west boundary of the site. This was the remains of a burned outbuilding which had once stood in this location.

\section{BX896 - NCB 636, Lots 4 and 5}

The structure present at 102 Martin Luther King Street (formerly Nebraska Street), known as the Demazieres House, was the only structure dating to the 1850 s still standing within the project area at the time investigations were carried out in 1990-1992 (Figure 4-49). Observation of the Sanborn maps over time indicated that this residential complex had affected two different lots (4 and 5) over the course of its history (Figure 4-50). At the time Phase II testing was done at the site (designated 41BX896), two other structures, both of pier-and-beam construction were also present on the lots (110 Martin Luther King and 706 Walnut).

The entire block was purchased in 1856 by Francis Louis Demazieres, who shortly thereafter constructed the limestone residence at 102 Nebraska (Martin Luther King) for his sister Sophia (BCDR N2:416). In 1874 Sophia sold the block to Bernard Mauermann who began selling off individual lots (BCDR 3:170).

Table 4-11. Site Artifact Frequency Distributions for 41BX895

\begin{tabular}{|c|c|c|c|}
\hline$\overline{\text { Group }}$ & $\#$ & $\%$ & Notes \\
\hline Activity & 103 & 3.78 & 24 wire frags. \\
\hline Architecture & 1,238 & 45.46 & 858 window glass \\
\hline Arms & 2 & 0.07 & 1 shotgun shell casing; 1 cartridge \\
\hline Bone & 505 & 18.55 & 395 from residence; 110 from store \\
\hline Clothing & 22 & 0.81 & 6 buttons \\
\hline Furniture & 3 & 0.11 & 2 light bulbs; 1 furniture part \\
\hline Kitchen & 815 & 29.93 & $\begin{array}{l}163 \text { bottle glass from residence; } 297 \text { bottle glass frags. and } 238 \text { whole } \\
\text { bottles (mostly vanilla) from store }\end{array}$ \\
\hline Personal & 35 & 1.29 & 23 coins from store \\
\hline Total: & 2,723 & 100 & \\
\hline
\end{tabular}




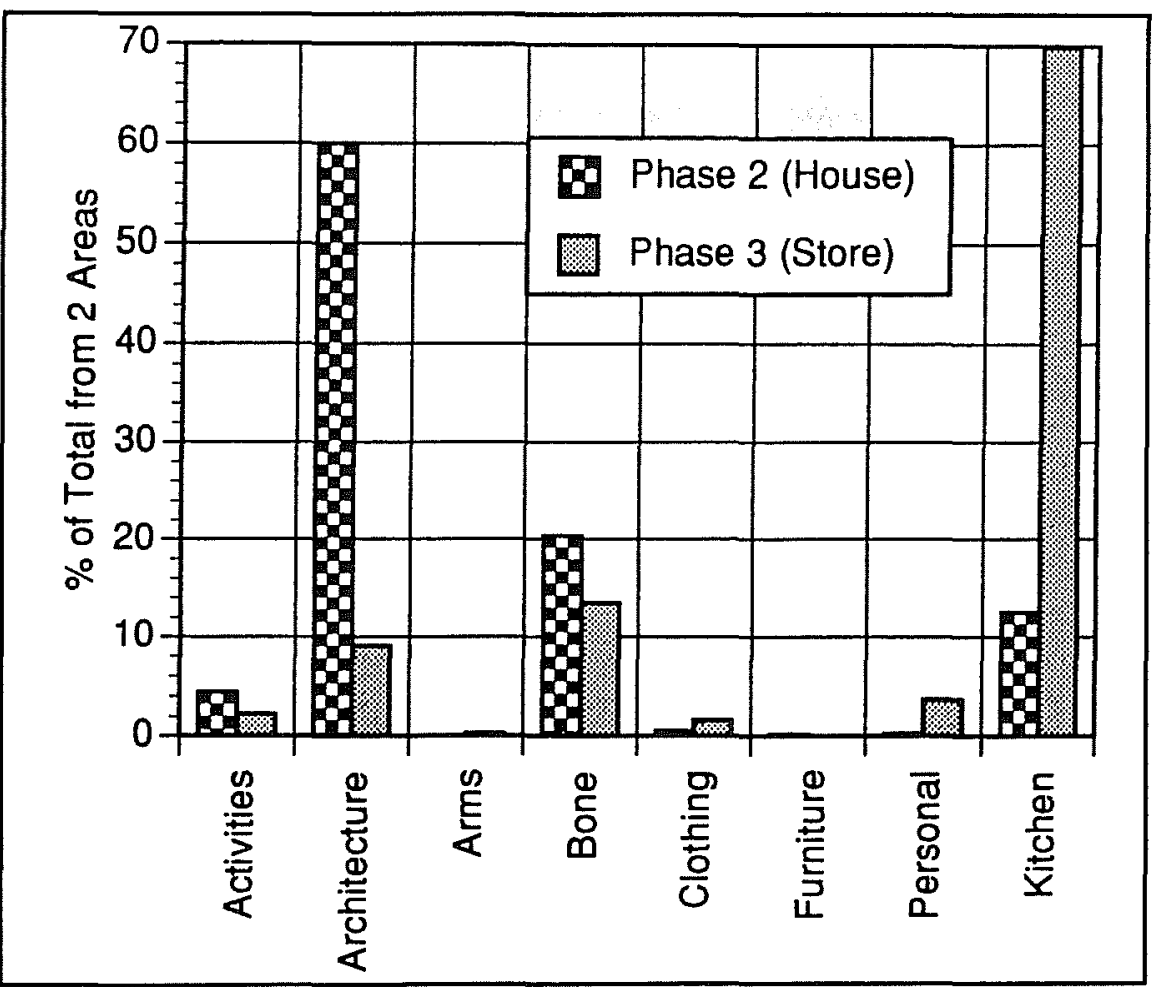

Figure 4-47.

41BX895, artifact group distributions.

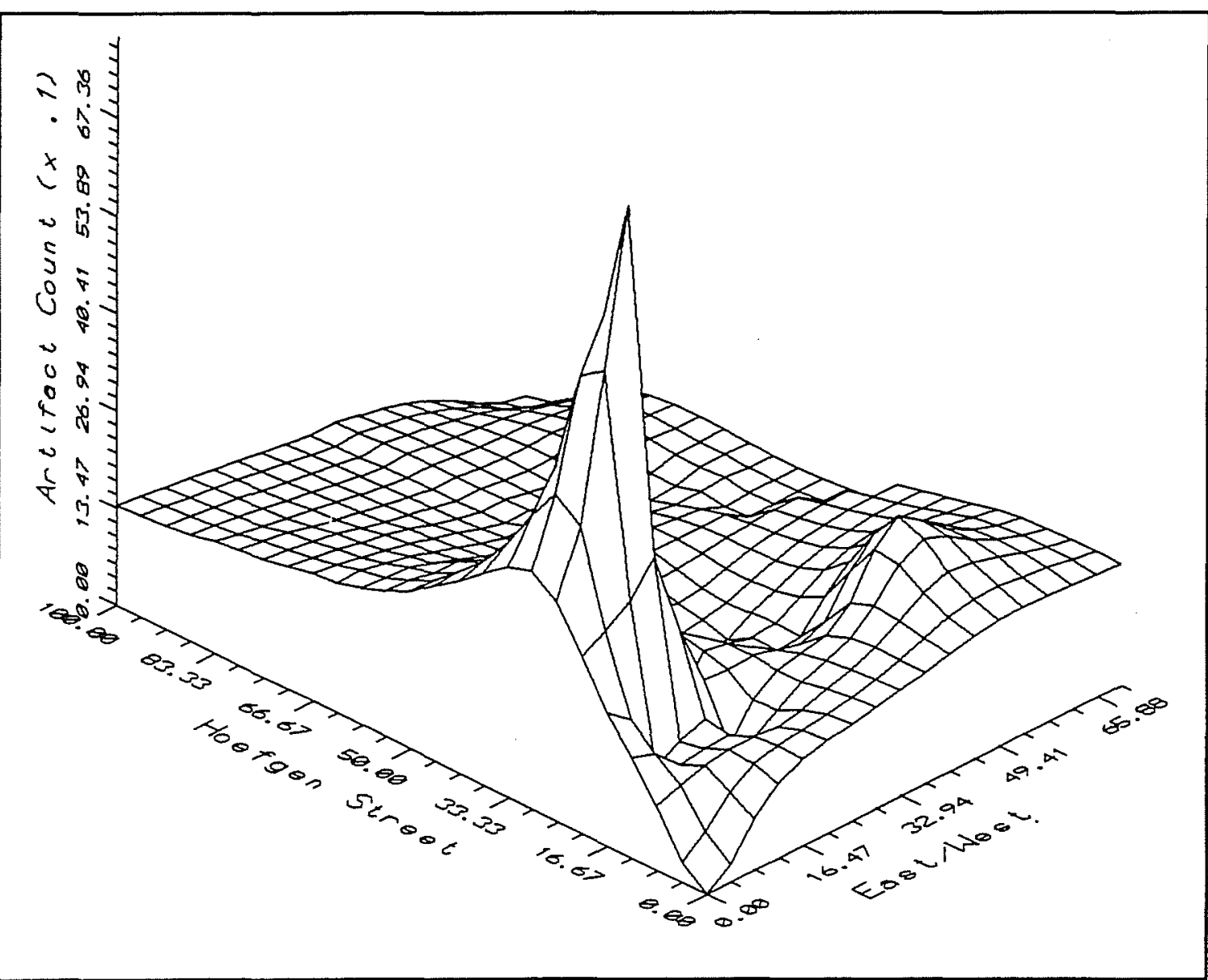

Figure 4-48. 41BX895, spatial frequency of artifacts (Phase II) across site. 


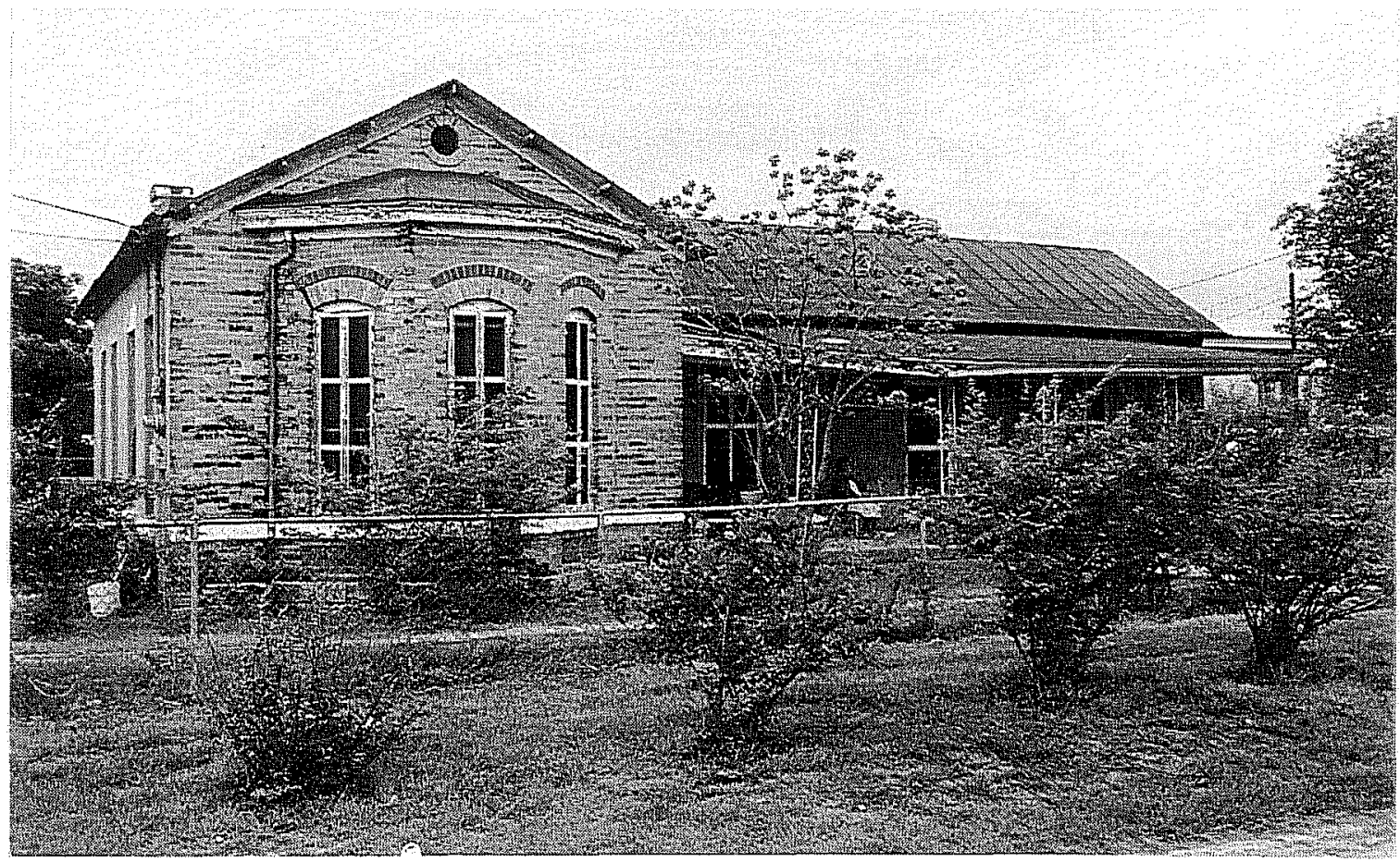

Figure 4-49. The Demazieres House.

The frame structure on Lot 4 (706 Walnut) was built in 1885 by Adolph Preuss (BCDR 34:377). The frame structure on the east end of Lot 5 (110 Martin Luther King) was constructed by the Rotzler family (then living at 102 Martin Luther King/Nebraska) as a rental property between November 1906 and November 1907. The first resident of this rental was E. F. Lowther (CD 1906-1907).

E. F. Rotzler, a stonemason by profession, had acquired the property in 1886 (BCDR 49:409). The Victorian limestone and brick additions were added at this time. Other frame additions appear to have been made in the 1920 s and the 1970 s.

The 1904 Sanborn map shows Lots 4 and 5 as distinct units. Lot 4 has a primary residence (706 Walnut) and a fair-sized outbuilding located along the north-central boundary of the lot. Lot 5 shows a primary stone dwelling (102 Nebraska), two small outbuildings along the center of the south boundary line; and a carriage house, with a single small outbuilding attached to its southwest corner, located in the southeast corner of the lot.

By 1911 the Sanborn map shows a significant change. Lots 4 and 5 appear to have been unevenly subdivided.
The eastern third of Lot 4 appears to have been cut out and a different primary residence placed in the same location as the previous one (706 Walnut). One small outbuilding occupies the southeast corner of the yard. Approximately one-half of Lot 5 to the east appears to have been cut out. A new residence occupies the northeast lot corner (106 Nebraska). Two small joined outbuildings occupy the central south boundary line for Lot 5 and a large rectangular outbuilding is present in the southeast corner of Lot 4 . The 1952 Sanborn shows almost the same arrangement except that the rectangular building in the southeast corner of Lot 4 is gone.

Even though it appears on the Sanborn maps that this irregular zone has been cut from Lots 4 and 5 for the establishment of the new residence at 106 Nebraska (later 110 Martin Luther King), early photographs and oral history suggest that Lot 5 was still largely under the control of the residents of 102 Nebraska and that these residents had gained control of the eastern end of Lot 4 (Dovie Hall and Will Rotzler, personal communication 1991). On the 1911 Sanborn map, it appears that a small rectangular section of both Lots 4 and 5 had been. fenced out along the east end to establish a back yard for 106 Nebraska (Figure 4-50). 


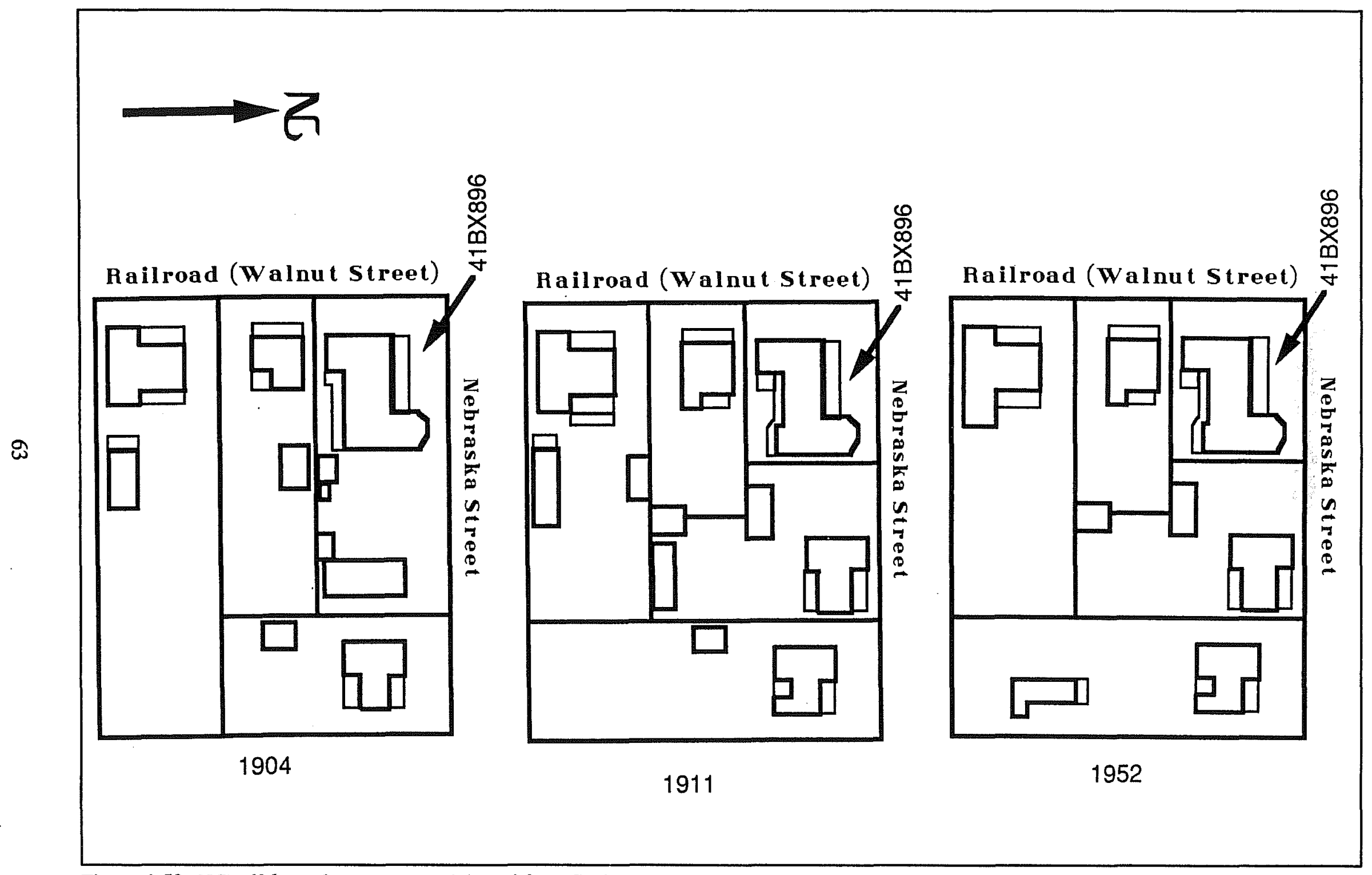

Figure 4-50. NCB 636, northwest corner. Adapted from Sanborn maps. 
At the time investigations began for the Alamodome Project, this situation had changed again. The dimensions for 706 Walnut were the same; however, 110 Martin Luther King had gained control of the entire yard area of the eastern third of Lots 4 and 5 . Only two outbuildings were present, both on Lot 4 . One was a very dilapidated structure located in the southeast corner of the 706 Walnut yard, the other was a very small 5-x-5-ft fiberboard structure (not pictured on the site map) located along the east boundary line of Lot 4 behind 110 Martin Luther King.

\section{Excavations (Figure 4-51)}

Based on Phase II testing of this site, we decided to carry out full-scale mitigation of the area. This was due to the discovery of significant artifact deposits and structural remains with a relatively good state of preservation. The descriptions of excavations carried out on 41BX896 are discussed in three parts: 1) Phase II testing; 2) Phase IV mitigation; and 3) Phase V dwelling interior excavations.

\section{Phase II Testing}

Between September 18 and September 28, 1990, test excavations were conducted on NCB636, Lots 4 and 5, designated 41BX896, the Demazieres House. A site datum (elevation $652.09 \mathrm{ft}$ amsl) was established in the northwest corner of Lot 5 where Martin Luther King and Walnut streets meet. It should be noted that Walnut Street became the location of the Southern Pacific Railroad, although some houses still front on the tracks.

After surface collections were performed, one 4-x-4ft excavation block, 16 2-x-2-ft test units, and two backhoe trenches-A ( $2 \times 32 \times .6 \mathrm{ft})$ and B $(2 \times 34 \times 2 \mathrm{ft})$ were excavated across the site. Unit placement was designed to investigate several structures represented on the Sanborn maps, as well as arbitrarily to provide balanced coverage of the site.

Stratigraphically, looking north to south across the site, the sterile, black clay matrix horizon appeared to be encountered at 6-8 inches below ground surface from
0-61 ft south; from $61-118 \mathrm{ft}$ south the sterile horizon was 12-16 inches below ground surface.

Five major activity zones were encountered during Phase II testing. One 2-x-2-ft unit (S118E143) located in the southeast corner of Lot 4 contained large amounts of artifacts of a domestic nature. Many whole bottles and ceramics were collected (Figure 4-52). This was a likely location for a trash pit or privy so we decided to cover the deposit and return during Phase IV mitigation when time and money would be available to fully explore the deposit. The deposit was designated Feature A (see below, also Brown and DeLaO Volume III).

One 4-x-4ft excavated section revealed a dog burial in the far southeast corner of Lot 5 (Figure 4-53). The dog appeared to be of a small breed such as a terrier. The most unusual aspect of the burial was that the dog's left scapula, left front leg bones, and several upper left ribs were missing. No visible trauma to any of the surrounding bones was visible. The best possible explanation for cause of death would be some sort of dislocation injury that removed the missing bones, yet did not traumatize any of the surrounding bone (some of the upper ribs present were broken; however, it was unclear if this had been done before or after death).

A 30-caliber Luger pistol cartridge was found in association with the burial, about one inch west of the rear legs of the skeleton. This was an unlikely cause of death as a pistol cartridge of this size would have caused significant trauma to the surrounding bone, but probably would not have been able to completely sever a leg in the fashion that was present. Although the casing showed evidence of having been fired, the proximal end of the casing had been flattened intentionally. The most likely explanation for the presence of the casing is that it was already present in the fill dirt surrounding the burial when it was placed. Several small fragments of plastic sack were found approximately two inches above the burial (at the nineinch depth); the dog may have been enclosed in a plastic bag when it was buried. Best estimates based on available information would put the burial at 20 to 30 years old (1960s) (Meissner Volume III, Chapter 12). 


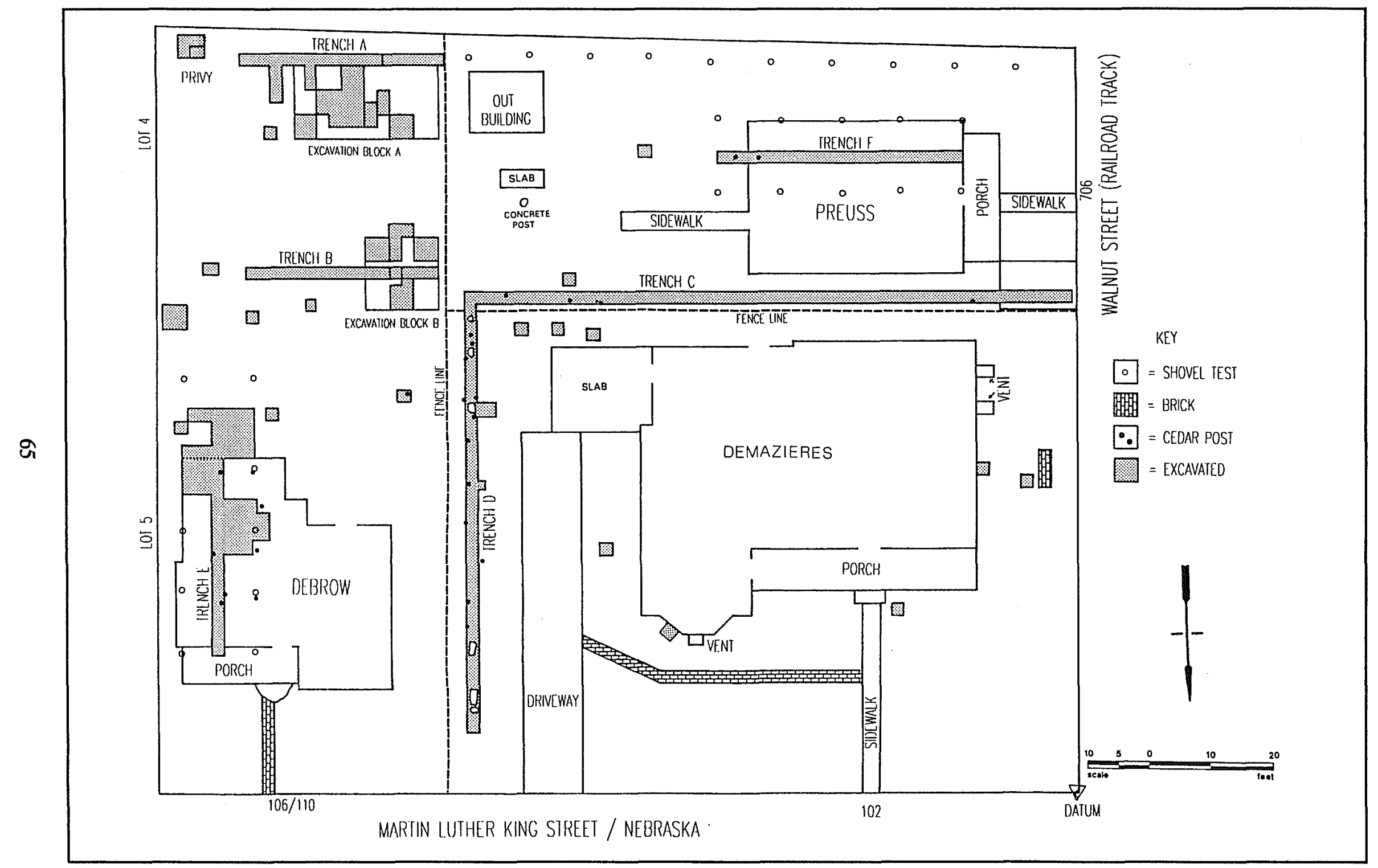

Figure 4-51. 41BX896, site map. 


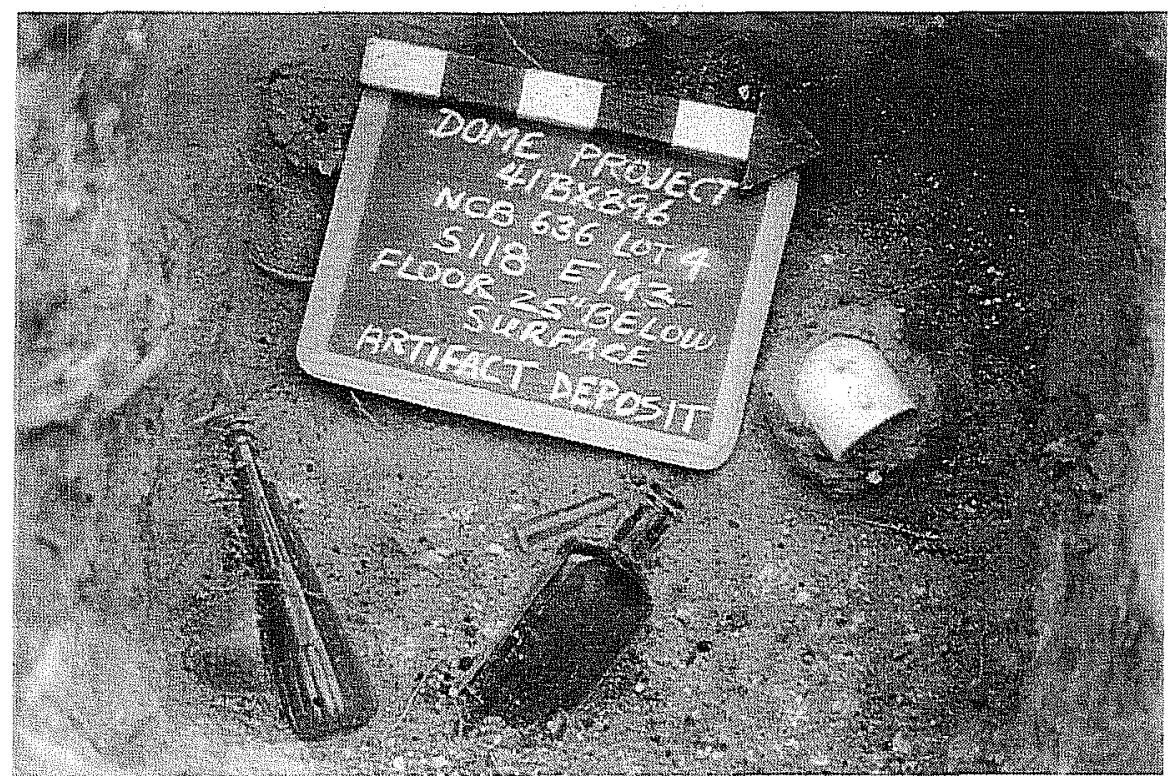

Figure 4-52. 41BX896 Feature A, earthen-vault privy deposit.

close to the surface. Within the first $10 \mathrm{ft}$, a decomposed cedar post was found at $7.5 \mathrm{ft}$ east. This post may have been related to the southeast corner of a small outbuilding pictured in this location on the 1911 Sanborn map.

At about $22 \mathrm{ft}$ east, several large flat limestone slabs were encountered in association with a small patch of plaster. Just past this, at $28 \mathrm{ft}$ east, a line of bricks appeared in both profiles. The 1911 Sanborn indicated this was a likely area for several outbuildings. Oral history had also indicated that there might be building

Four 2-x-2-ft test units were placed immediately off the southeast corner of the Demazieres house to examine an area that had been occupied by several outbuildings between 1904 and 1952. Three of these units (S74E78, S75E84, S75E90) produced large quantities of architectural-related artifacts, as well as definite layers of brick and brick fragments at 8-9 inches below ground surface (Figure 4-54). The orientation of the brick was mixed, with no definite order to their placement. remnants within this area (Dovie Hall, personal communication 1991). We decided to cover the bricks and limestones with plastic and to explore the area more fully during Phase IV mitigation.

Trench B

Trench B was another shallow backhoe trench, placed five feet south of the north side of Lot 4. This was an east/west trench, the west end of which was located just east of the fenceline marking the back of the yard for 706 Walnut. About 7-8 ft east into the trench, an

\section{Backhoe Trenches}

\section{Trench A}

Trench A, 34-ft in length, ran east/west across the south boundary of Lot 4 . The west end rested at a fenceline located $103 \mathrm{ft}$ east of Walnut Street (the fence separated the yard of 706 Walnut from that of 110 Martin Luther King). The first $10 \mathrm{ft}$ of the trench were excavated to a deeper level (approximately 28 inches) to look for stratigraphic differences. The remainder was kept fairly shallow to search for structural features

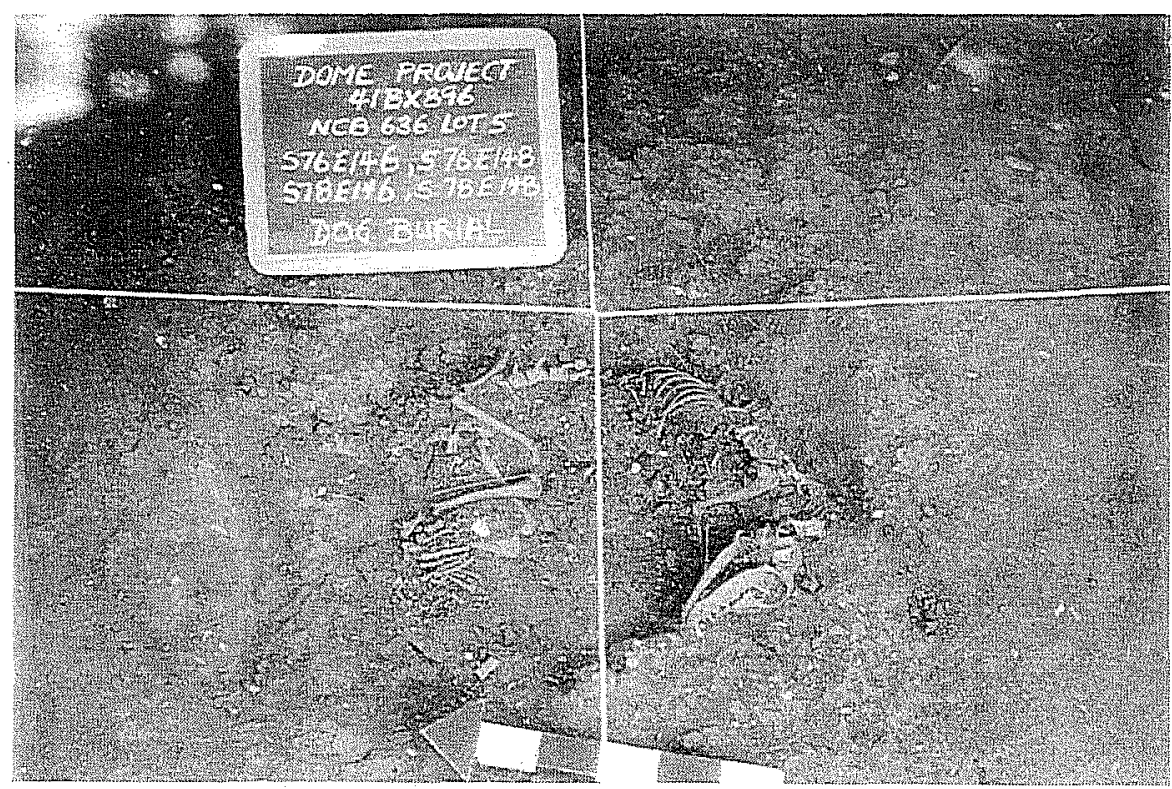

Figure 4-53. 41BX896, Phase II, dog burial. 


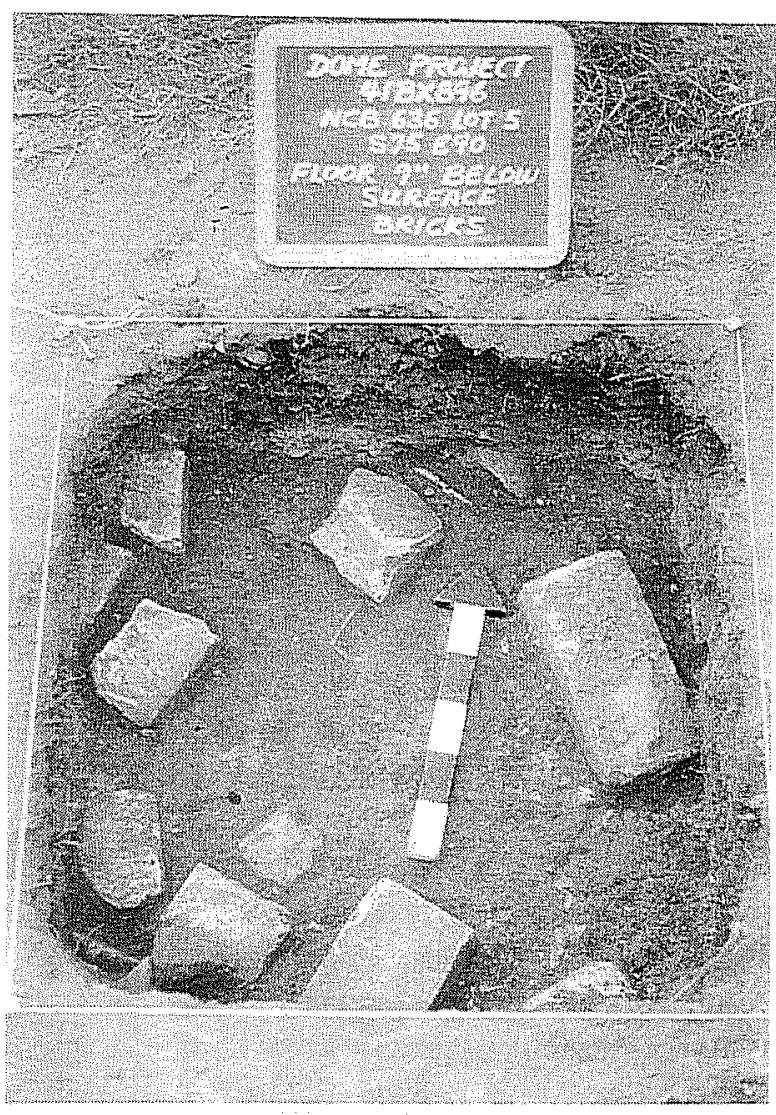

Figure 4-54. 41BX896, brick layer.

alignment of bricks was encountered running across the trench in a north/south direction. No other significant structural features were present in the trench. Four possibilities presented themselves as the most likely explanations for this brick alignment.

1) This was in the area occupied by an outbuilding pictured in the 1911 and 1952 Sanborn maps and could be remnants of that structure. However, the trench was placed a short distance to the south of where we would have expected to encounter existing remnants for the structure if the Sanborn maps were accurate.

2) A possible border for a driveway which was servicing outbuildings placed further south on the lot.

3) Possibly a border for gardening activities carried out on the lot.

4) The remains of an outbuilding not pictured on any Sanborn map which could have occupied this spot.
With these possibilities in mind, we covered this section of trench with plastic to be further explored during Phase IV mitigation.

\section{Phase IV Mitigation}

Between February 11 and March 27, 1991, mitigative excavations were carried out at 41BX896. The majority of work was performed between February 11 and March 1; however, Feature A continued to be investigated through March 27. In the interim between the end of Phase II and the start of Phase IV, much time had been spent developing a strategy for investigations of the features revealed during the Phase II operation on the site, and for providing further coverage of areas of the lot not examined during Phase II.

Coordination with demolition contractors working in the area greatly facilitated efforts at this time. The two houses directly adjacent to the Demazieres-one referred to as the Preuss house (706 Walnut) and the other as the Debrow house (110 Martin Luther King)-were slated for demolition. Arson had been committed on the Debrow house on September 26, 1990 , so not much was left of it except a shell. Indeed three arson attempts were made on the Demazieres house during the time of the project, the first within three days after the house was abandoned by its last residents. Two of the attempts were semi-successful, one we discovered in the act of being committed and were able to call the fire department in time to stop any damage. With the cooperation of the demolition crews, the houses adjacent to the Demazieres house were removed with little subsurface disturbance. This provided the opportunity to expand our efforts to include the areas beneath where these structures had stood.

Several decisions had been made regarding changes in approach to this site between testing and mitigation.

1) Several large blocks would be set up encompassing previously discovered activity areas. These blocks would utilize 4-x-4-ft units rather than the 2-x-2-ft units employed during testing (however 2-x-2-ft units could be used if needed in certain areas). 
2) A more aggressive backhoe program would be implemented focusing on areas peripheral to the Demazieres house itself and areas beneath the two adjacent structures which had been removed.

3) Supplementary to the backhoe trenches to be placed beneath the locations of the two adjacent structures, a series of flanking shovel tests would be run to examine sheet refuse around those areas of the lots.

Several other minor investigations were done during the mitigation, including testing the foundations of the Demazieres house in several locations to see if there was a significant difference between the foundation depth of the 1850 s and that of the 1880 s section. A test unit would also be placed in the basement beneath the kitchen to test for features.

Mitigation produced nine 4-x-4-ft blocks, 19 2-x-2-ft units (of which 11 were placed within two large excavation blocks), four backhoe trenches totaling around $250 \mathrm{ft}$ (one trench was significantly extended to the sides), 29 shovel tests, and two foundation tests. Eight of the nine 4-x-4-ft units and 11 of the $192-x-2-f t$ units were placed within the confines of two large excavation blocks. The northwest corner of Excavation Block A, which measured $12 \times 24 \mathrm{ft}$, was located at S107E103. This positioned the block near the south boundary line of Lot 4 , just inside the edge of Backhoe Trench A from Phase II (Figure 4-51). This location would allow investigation of the brick and limestone occurrences that had been revealed by Backhoe Trench A. Excavation Block B, which measured $12 \times 12 \mathrm{ft}$, had its northwest corner at S79E103. This placed the entire block approximately $16 \mathrm{ft}$ to the north of Excavation Block A. The east sides of the two blocks were in direct line north to south with each other and were located one foot outside the east end of the fenced yard of 706 Walnut. The location of Excavation Block $B$ allowed investigation of a brick alignment discovered in Backhoe Trench B during Phase II testing.

\section{Excavation Blocks}

Excavation Block A (Figure 4-55)

Initially, 4-x-4-ft units were selected at random within the 12-x-24-ft block. When features were revealed, additional units were opened to expose them. The most significant structural feature revealed within this block was the remnants of the north side of a large outbuilding. A brick alignment approximately eight feet long, running in an east/west direction, was located $13 \mathrm{ft}$ north of the south boundary fence of Lot 4. The first evidence of the west side of the structure was encountered about $12 \mathrm{ft}$ east of the back fenceline of 706 Walnut.

Evidence of a northeast corner to the structure was found. After running west to east for about eight feet, the bricks turned south and ran in that direction for about three feet before ending. Several indications that this brick alignment represented the outer dripline of a slightly smaller interior structure were present. A definite soil break was present to the north and south of the bricks. To the north of the bricks the soil was composed of an orange/yellow fill dirt, while to the south of the bricks the soil was a dark grey to ashy color. Also, approximately two feet south of these bricks, a secondary alignment of brick and stone was encountered with horizontally laid strips of wood between them. The wood was in a bad state of preservation. Just to the south of this secondary alignment, another significant soil break was present. The previously mentioned dark ashy soil changed to a predominantly limestone caliche fill surface.

The limestone slabs and brick encountered in Trench A during Phase II testing, once exposed, revealed other brick and limestone running from 1.5-5 inches deep within the trench. No discernable pattern was evident. The soil surrounding these bricks and limestone slabs was similar to the ashy dark soil revealed inside the previously mentioned brick alignment. However, it cannot be stated with assurance that there is an association between the slabs and bricks present in Trench $A$ and the structural features exposed within Excavation Block A. The 1911 Sanborn map shows two structures running across this part of the lot, however the placement of those structures does not match the location of the brick corner exposed within Excavation Block A. 


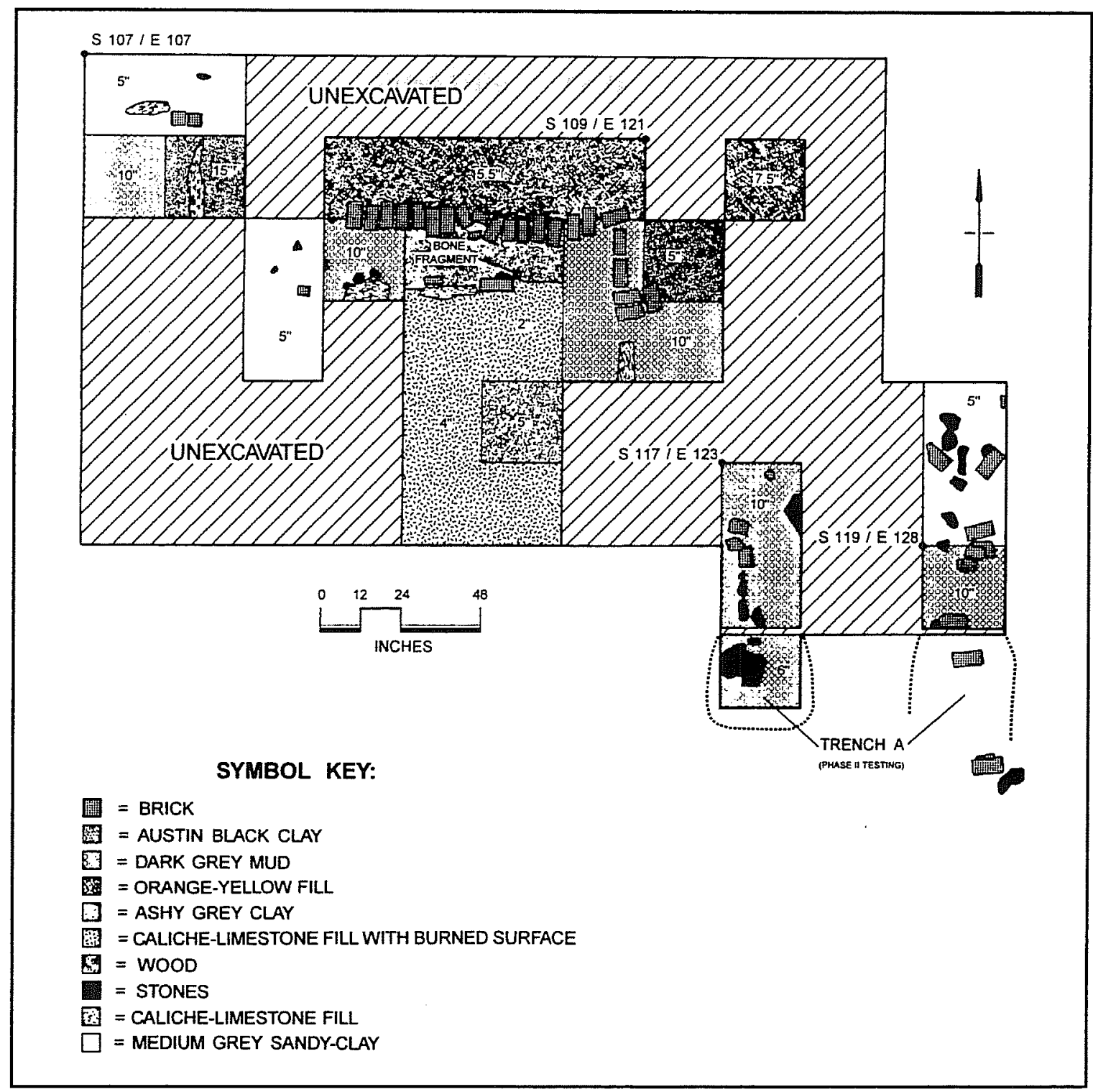

Figure 4-55. Excavation Block $A$.

Two informants who had lived on the property during the 1940s described a garage/workshop which may have occupied this part of the lots. The garage burned down in a dramatic fashion, causing significant embarrassment for one of the informants (Dovie Hall, personal communication 1991). Evidence was present that a structure in this location had burned; it is likely that what was exposed in Excavation Block $A$ was the remnants of the garage/workshop complex which burned in the 1940s. Since the building does not line up with the structures pictured in the 1911 Sanborn map, it is likely that there was an earlier structure which had been removed and a smaller structure built in the same vicinity between 1911 and 1940 .
Excavation Block B (Figure 4-56)

This 12-x-12-ft block was positioned to investigate a north/south brick alignment revealed in Backhoe Trench B during Phase II testing. Excavations within the block revealed the east side of a small outbuilding measuring approximately $10 \mathrm{ft}$ wide north to south. This outbuilding is not pictured on any of the Sanborn maps and is too far south to be associated with a centrally placed outbuilding pictured in the 1911 and 1952 Sanborns. This was probably an outbuilding predating 1904, since no Sanborn map shows the structure, and after 1911 there was a structure present just to the north which would have interfered with access to a building in this location. 


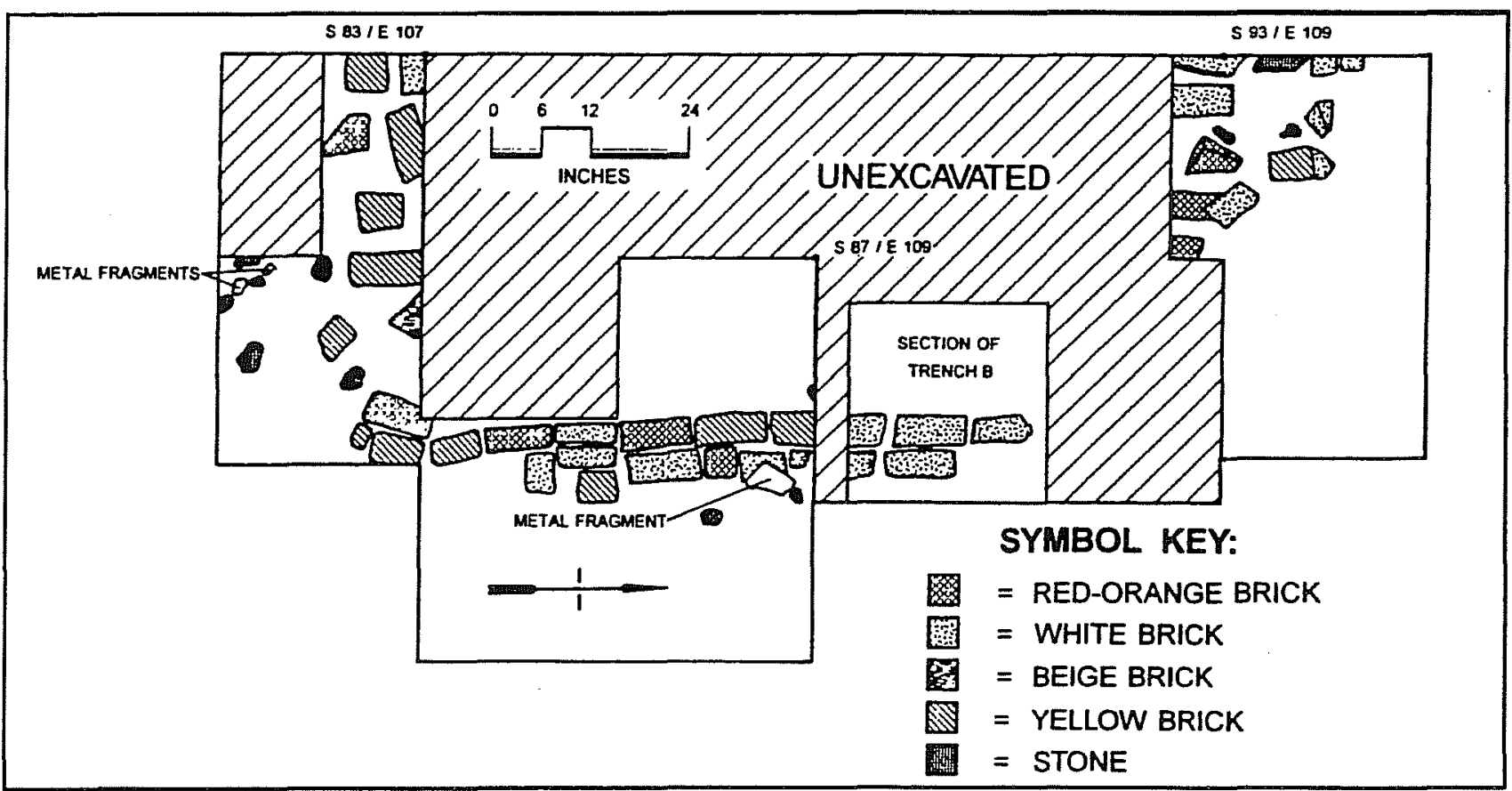

Figure 4-56. Excavation Block $B$.

Backhoe Trenches

As previously mentioned, four backhoe trenches totaling about $250 \mathrm{ft}$ were placed on this site during Phase IV. It should also be reiterated that the methodology of working the backhoe trenches changed significantly, with the trenches being divided into $10-\mathrm{ft}$ sections, with all sections receiving like treatment.

\section{Trench C}

This $100-\mathrm{ft}$ trench was the longest trench placed on the site. It was located immediately inside the north boundary line of Lot 4, running east/west on the east side of Walnut Street. Average width of the trench was 24-30 inches, average depth 1.5-2 ft.

Within the first $35 \mathrm{ft}$, Trench $\mathrm{C}$ bisected an outbuilding shown on the 1904 Sanborn map as having rested on the north-central boundary line of Lot 4 . Structural evidence for this building was indicated by the presence of several cedar post remnants found along what would have been the north side of the structure. These were found at $17 \mathrm{ft}$ and $21.5 \mathrm{ft}$ west in the trench, approximately two feet below the surface. Stratigraphically, a layer of white caliche marl was present running through the entire area that would have been occupied by the structure. This was located at a depth of 7-14 inches below ground surface and was 3-4 inches thick. This marl was probably laid as fill for the interior of the structure.

A layer of brick and limestone was encountered approximately six inches below ground surface at 29-32 ft west. This would have been immediately outside the west end of the outbuilding; the brick and limestone were apparently placed to form a doorstep or entrance to the building. No other structural features were encountered within the trench. Most cultural material was found from 0-18 inches, except toward the western end of the trench from $89-100 \mathrm{ft}$ where the cultural deposit thinned to about six inches.

Trench D (Figure 4-57)

This was a $70-\mathrm{ft}$ long trench designed to run north/south, perpendicular to Trench $C$. The south end of Trench $\mathrm{D}$ connected with the east end of Trench $\mathrm{C}$. Several suspected activity areas were bisected by this trench: a small outbuilding complex pictured on the 1904 Sanborn map, and a larger double outbuilding shown on the 1911 and 1952 Sanborn maps.

The stratigraphy for the first 10-ft section of Trench $\mathrm{D}$, running north from Trench $\mathrm{C}$, was difficult to interpret. From the beginning of the trench to approximately 40 inches, was a very disturbed mixture of brick fragments, caliche, and sand with no apparent 


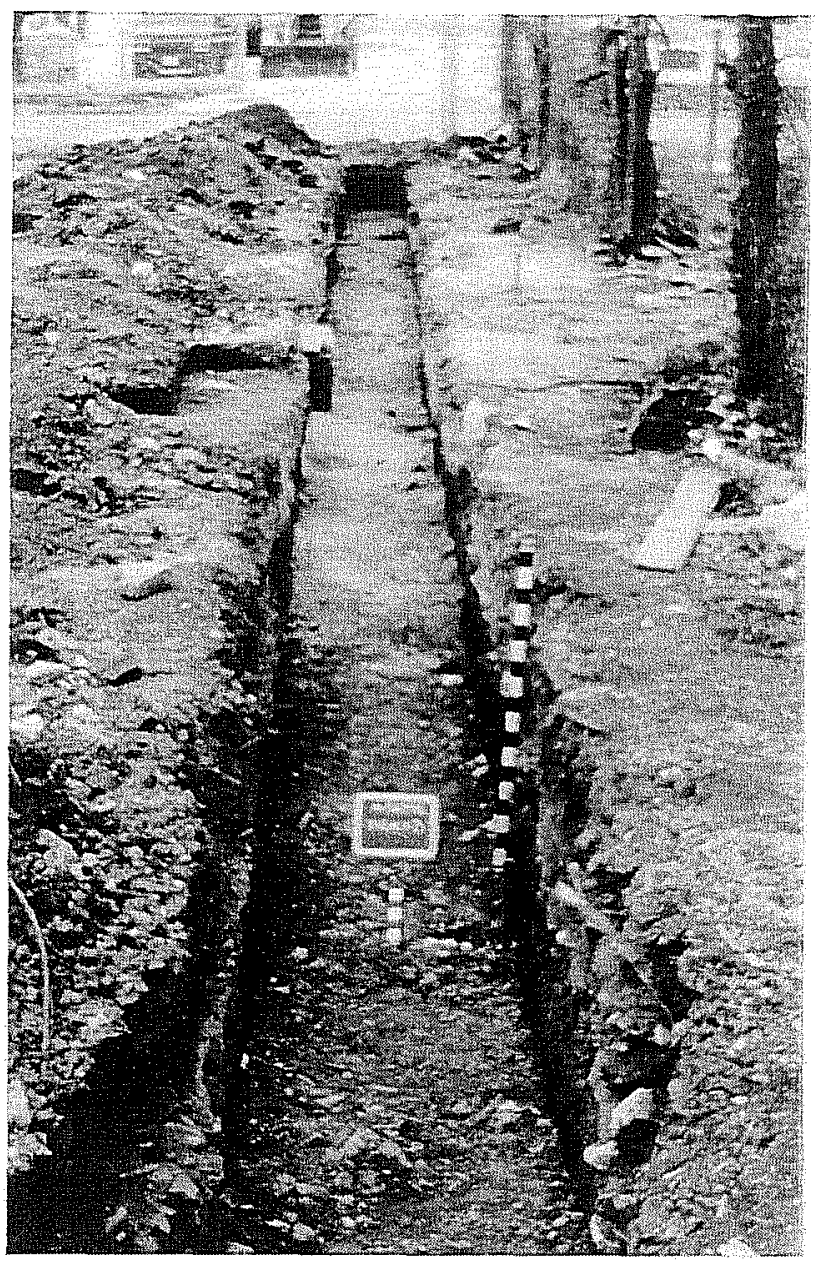

Figure 4-57. Trench $D$.

form or design. The surface of this mixed deposit started around 11 inches below the ground surface. It should be noted that the Phase II test pits placed running west of this part of the trench also presented the same aspect. The trench was excavated to a depth of 28 inches. At a depth of about 18 inches, the soil changed to a sterile black clay. The stratigraphic disturbance continued in the west profile and was also observed in the north profile of Trench C. From 22-40 inches in the east profile of Trench $D$, the mixture is quite intense. Just outside of the disturbance zone running north at a depth of 25 inches, a post mold was discovered in the center floor of the trench. The fill for the post mold was composed of brick and rock chunks mixed with a light yellow fill which contrasted sharply with the surrounding black clay matrix. A little further north in the trench $(5.5 \mathrm{ft})$ an intact cedar post was discovered starting 18 inches below ground surface and running to 28 inches deep. It was surrounded by the same yellowish fill. This post measured about three inches in diameter.

A second zone of brick, plaster, sand, limestone, and metal was observed from 7-10 ft north in the trench. A second post mold, six inches in diameter, was present in the east profile at nine feet north. Past $10 \mathrm{ft}$ south in the trench, the stratigraphy became less disturbed and clear evidence was present for the centrally located outbuilding pictured in the 1911 Sanborn map. At $18 \mathrm{ft}$ north, a series of limestone pavers was found running from the west profile further west approximately three feet (Figure 4-58). A heavy concentration of brick crossed the trench at this point, running east, and at $16 \mathrm{ft}$ north, cedar post remnants were found in both the east and west profiles. We felt the limestone pavers represented an entryway into the north side of the structure pictured in the 1911 Sanborn map; however, to further test this, a 2-x-2-ft test unit was placed to the east of Trench $D$ at a point calculated to have been the northeast corner of the structure. A large six-inch diameter cedar post, which was likely to have been the northeast corner post for the structure, was discovered in this test. The acquisition of $1920 \mathrm{~s}$ photographs of this site confirmed the location and appearance of this structure (Rotzler family, personal communication 1991).

At approximately $18 \mathrm{ft}$ north, another post was found at a depth of 20 inches in the center of the trench. Between 20 and $30 \mathrm{ft}$ north, a post mold was found at approximately $23.5 \mathrm{ft}$, and the remnants of a six-inch diameter cedar post were located at $29.5 \mathrm{ft}$. Both occurrences were in the east profile. Also at $29 \mathrm{ft}$ north in the west profile, two large limestone pavers were found. Two possibilities were discussed to explain the presence of these features. The posts may have represented the remains of a fenceline and the pavers a gateway through the fence. Or, the posts represented the east side of a structure not pictured on any Sanborn map and the pavers provided an entrance into the structure. Of these possibilities the second seems more likely. Trench D had been established well to the west of where a projected fenceline would be expected to be encountered (indeed at the time excavations started a chain-link fence was present occupying the zone felt most likely to contain remnants of an earlier fenceline). 


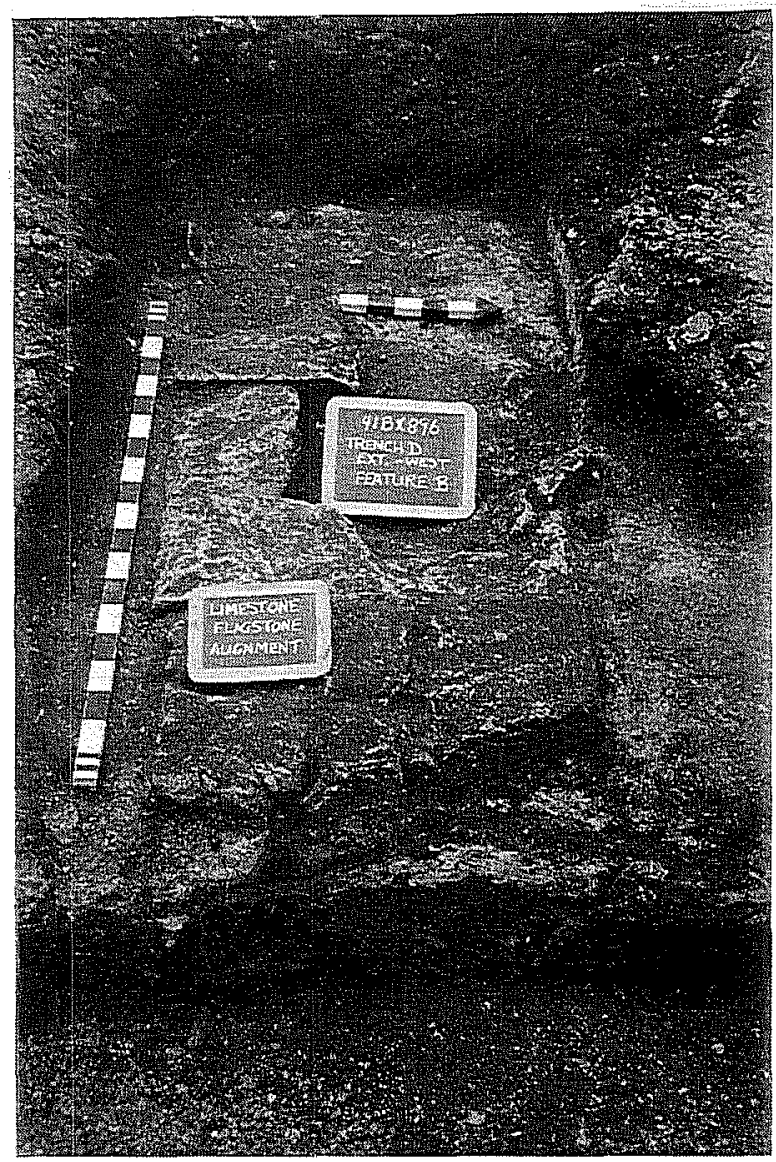

Figure 4-58. Trench D, Feature B, limestone pavers.

The only other notable occurrence within the trench was at 61-66 ft north in the trench. Here the remains of what was felt to be a brick and limestone construction front fence was encountered running east/west across the trench (Figure 4-59).

Trench E

Trench $\mathrm{E}$ was originally designed to measure $2 \times 40 \mathrm{ft}$ and to be placed beneath the foundation of 110 Martin Luther King Street (on the east side of Lot 5). The 1904 Sanborn map had indicated the presence of a large carriage house at this location, so investigations in this area were deemed important to the overall site interpretations. Once the pier-and-beam house had been removed by demolition crews, exploration could proceed. Removal of the house was monitored closely by field crew members and the structure was taken down in such a way as to minimize soil disturbance underneath.
The north end of Trench $E$ was located $10 \mathrm{ft}$ inside the east boundary of Lot 5 and $23 \mathrm{ft}$ south of Martin Luther King Street. No evidence of any earlier structure was extant on the surface once the frame structure had been removed. Several support posts for the later structure were still present as excavations began.

Approximately $16 \mathrm{ft}$ south in Trench E, a soil change was encountered as the context became more mixed, and a cedar post was encountered in the east profile of the trench at this point. At $21 \mathrm{ft}$ south, the remnants of a poorly preserved brick surface set in a light plaster began to appear. At $23.4 \mathrm{ft}$ south, the brick surface was disturbed by a 1.5 -inch water pipe crossing the trench east/west. The brick surface continued to show up at a depth of five inches below ground surface back to a distance of $38 \mathrm{ft}$, where it stopped abruptly.

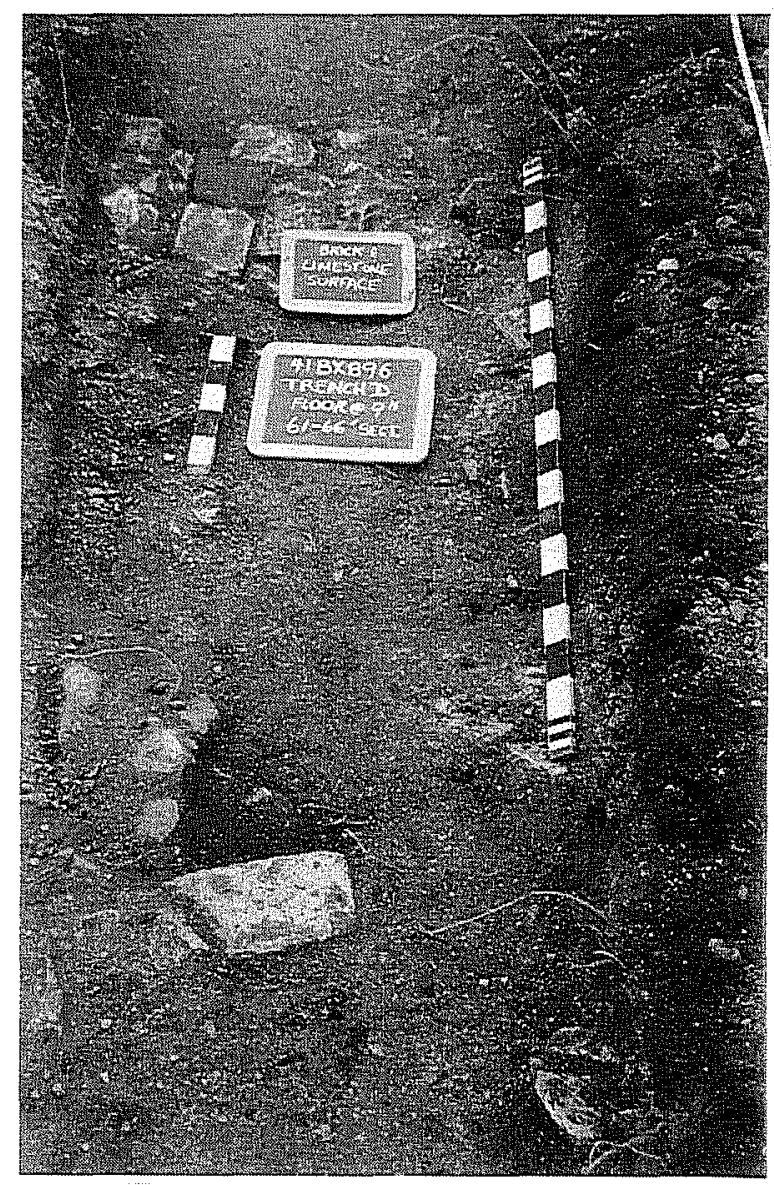

Figure 4-59. Trench $D$, brick and limestone wall remnant. 
We decided to open several extensions to the east and west to provide a better perspective of the nature and size of this brick surface (Feature $C$ ). The first extension (Trench E, South Extension) exposed areas both east and west of the original trench. A zone from 26-34 ft south was extended off the east profile about five feet. A zone from $32-40 \mathrm{ft}$ south was extended off the west profile about five feet.

A larger, uneven brick surface set in light plaster, with some limestone also present, was revealed. The width of the surface east/west appeared to be about $12 \mathrm{ft}$. One surprising aspect was that although some of the bricks were set two deep, most of the bricks comprising the surface were fragments rather than whole bricks. Most of the bricks were red or yellow in color and bore no visible marks, with the exception of one yellow brick impressed with an "M." This kind of brick was encountered in excavations conducted by John W. Clark, Jr. (1989) in a Mexican-American barrio in Laredo, Texas. However, no chronology for this kind of brick was presented in his report. Other single-initial bricks ("P" and "Q") were found in Laredo (Clark 1989) and at the Smith House (41BX650) in San Antonio (Waynne Cox, personal communication 1991). The latter dates to around 1898 (Nightengale et al. 1989).

Subsequent to the exposure of this area, a series of flanking shovel tests was run five feet to either side of the trench. Shovel Test 23 revealed a surface of some kind which extended northwest of the area we had already exposed. An additional extension (Trench E, North Extension) was run from $16-25 \mathrm{ft}$ south, seven feet off the west profile. The extension revealed that the surface did indeed extend into this area; however, its composition differed. In the southern part of the exposed area the primary surface component was fragmentary brick, in the north it was limestone. Several cedar post remnants, which were likely to have been the northeast corner post for the structure, were also revealed.

Several statements could now be made regarding the feature revealed here.

1) The surface probably represented the interior space of a structure. The structure was at least $12-15 \mathrm{ft}$ wide, with a south wall approximately
$63 \mathrm{ft}$ from Martin Luther King Street (Figure 4-60).

2) The surface matched the size and placement of the structure represented on the 1904 Sanborn map, with the exception that this surface only measured $24 \mathrm{ft}$ in length while the Sanborn map structure measured $30 \mathrm{ft}$ in length (perhaps part of the floor was not paved).

3) The brick composing the floor does not appear to match any of the other brick recovered from across the site. If the " $M$ " brick was produced at the same time as some of the other singleinitial bricks found in both San Antonio and Laredo, then a construction date of about 1898 is suggested.

4) A fairly distinct boundary exists between the sections of floor surfaced with brick and those surfaced with limestone. These two areas may denote different activity zones within the same structure.

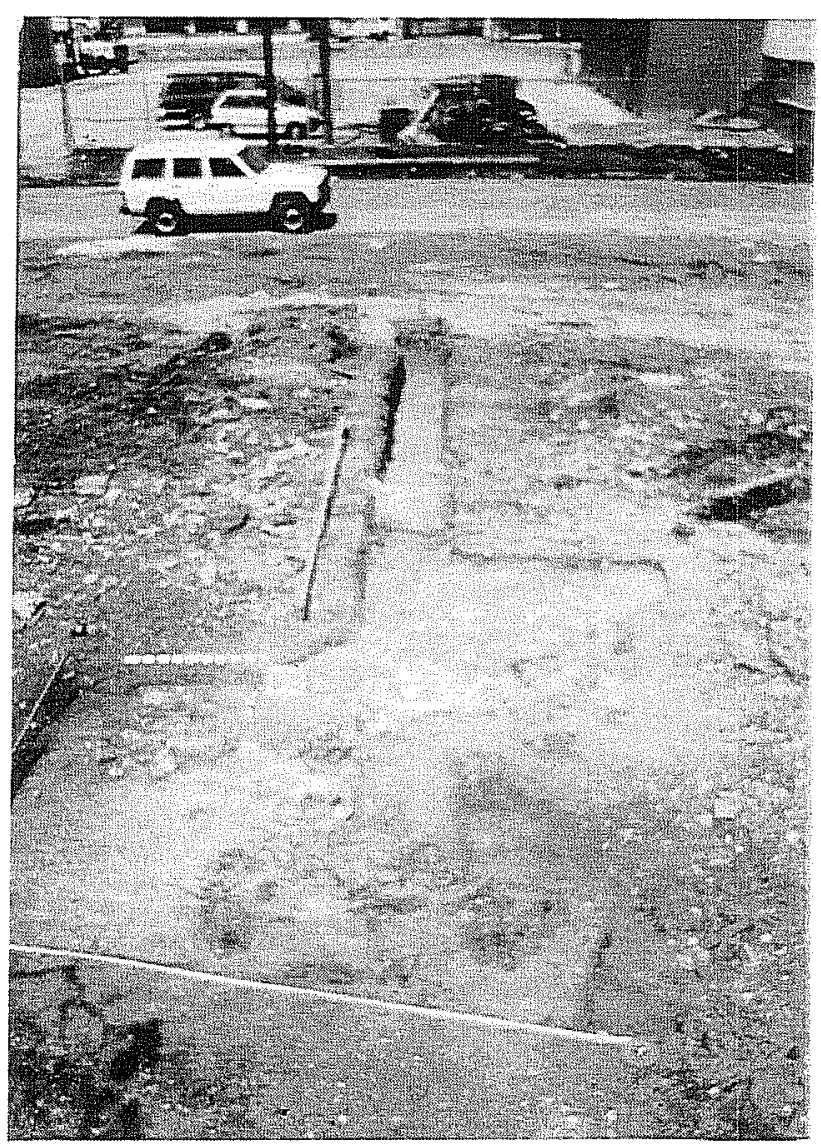

Figure 4-60. Trench E, carriage house. 


\section{Trench F}

This 2-x-40-ft trench was placed running east/west on the west end of Lot 4 . Once the residence present in this location at 706 Walnut was removed, the trench was placed across the area that had been occupied by the house. A noticeable depression, 1-1.5 ft deep, was present under the area where the house had stood.

Some evidence was found to support the possibility indicated in the Sanborn maps that an original house had been removed between 1904 and 1911 and a second house placed in the same location. At approximately three feet west in Trench $F$, a large cedar post was found. The post mold was filled with brick fragments. This post was not far enough west in the trench to be associated with the house which had just been removed. As the trench continued, posts associated with the just-removed house were found to have concrete footings. Several artifacts, including soda bottles and transferware ceramics, dating to around 1900 were revealed beneath the house foundation.

\section{Shovel Tests}

Twenty-nine shovel tests were placed across the site, primarily on the south perimeter of Lot 4 and flanking Trenches $E$ and $F$. Notable features revealed by some of these tests were:

1) ST \#3 - Located on the south side of Lot 4,80 ft east of Walnut Street. A complete dog burial with the remnants of a blue blanket around it. The skeleton appeared to be of a very young individual and was probably a sporting or hound breed. No cause of death was determined and no obvious bone trauma was present (Meissner, Volume III, Chapter 12).

2) ST \#17 - A concrete footing for a support post to 706 Walnut.

3) ST \#23 - Placed flanking west side of Trench E. Revealed a limestone surface (Feature D) associated with the previously described carriage house (Feature $\mathrm{C}$ ).

4) ST \#25 - Several red and orange bricks in alignment, appears to be a corner. This is possibly associated with a small structure pictured adjacent to the carriage house in the 1904 Sanborn map.

Feature A - An Earthen Vault Privy

During Phase II testing of this site, as mentioned above, a 2-x-2-ft unit placed in the southeast corner of Lot 4 (S118/E143) yielded high densities of artifacts (Figure 4-52). This unit was excavated to a depth of 40 inches, with artifacts still present at that depth. The decision was then made to cover the deposit and return during Phase IV mitigation of the site to further explore these deposits. During Phase IV, the original $2-\mathrm{x}-2-\mathrm{ft}$ test unit was expanded to the south and east to incorporate it into a larger $4-\mathrm{x}-4-\mathrm{ft}$ unit. The remains of an earthen vault privy, extending from just below the surface to a depth of about 60 inches, were revealed in this unit. The vault itself measured 3-4 ft square at the surface, and narrowed to 23 inches across at the bottom. The interior was filled with varying layers of clay-like and ashy soils. The interior of the vault appeared to have settled in the center in a fashion such as that described by Noël Hume (1969: 140-141).

Unlike some of the other privies encountered in the area, this one appeared to have never been cleaned out. The fill spanned a period of approximately 26 years and perhaps more. Dating of the deposits-based on ceramic maker's marks recovered from the privy vault-indicated that the upper portions of the vault (0-15 inches) were filled around 1900-1920, while the lower levels (50-55 inches) dated to around 1891-1897. The mean date of the fill was about 1902. The stratigraphy of the privy indicated that the upper 30 inches of the vault was primarily filled with trash deposit, while the lower 30 inches showed more evidence of night soils and primary use mixed with artifacts.

A variety of artifacts, mostly of domestic nature, was derived from the privy vault. A large, rectangular wooden box, possibly a wooden trunk, was present toward the bottom of the deposit. It appeared to line almost the entire bottom of the vault. Many ceramics, combs, an enema bag, egg shells, and lime deposits mixed with newspaper fragments were present. Compared with other privies excavated in the area, few bones were recovered, with the notable exception 
of those of a large fish on a ceramic plate near the bottom of the vault, and the remains of three rabbits.

This privy was probably associated with the occupation of Lot 4 (706 Walnut) by Adolph Preuss in 1885. The 1904 Sanborn map indicates that this area was included in this lot rather than that of the Demazieres residence (102 Nebraska) at that time.

\section{Phase V Interior Structure Tests}

Subject to recommendations made by the Texas Antiquities Committee, plans were made to conduct excavations under the floorboards of different sections of the Demazieres house interior. Each room of the house was given a designation, and unit placement was indicated by cardinal directions within the specific rooms (Figure 4-61). Architectural examination of the house foundations had suggested that the oldest portion of the house (1850s) was a rectangular section, measuring roughly $14 \times 35 \mathrm{ft}$. We designated this portion Bedroom 1, Entrance Hall, and Living Room.

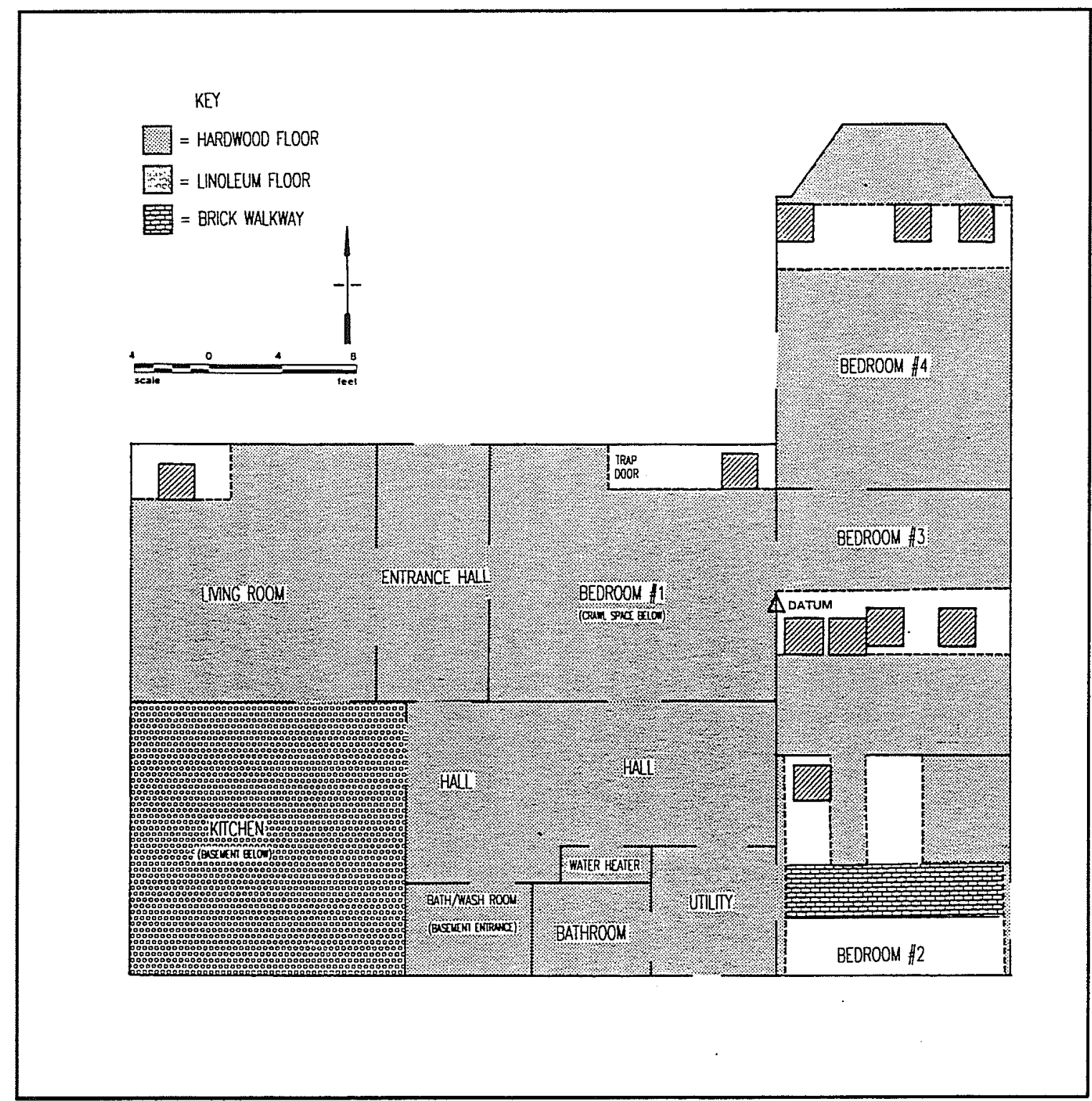

Figure 4-61. 41BX896, house interior excavations. 
When the Rotzler family obtained the house in 1886 , they probably added the areas of the house which we designated Bedroom 3, Bedroom 4, Kitchen, and Basement (located below the kitchen). Examination of the condition of the floorboards in the different rooms showed that some were similar, while others were quite different. The floors in the Living Room, Entrance Hall, Bedroom 1, and Bedroom 3 were all about the same age. They appeared to be constructed of the same material and to be in about the same state of deterioration. The only major difference hindering this assessment was with the Living Room and Entrance Hall. As mentioned before, several attempts at arson had been committed on this house since its abandonment at the beginning of the Alamodome construction. The result was that the floors of both of these rooms had been badly burned, so comparison with other floors in the house was more difficult. A short summary of the condition of the floors in each room at the start of the investigations follows.

1) Living Room - Badly burned to the point where structural integrity of the floor was compromised in several places. Roof and wall debris covered large sections of the floor.

2) Kitchen - Floor covered with melted and charred plastic tile.

3) Entrance Hall - Badly burned, primarily on the west side, east side in fair condition.

4) Hall, Bathroom, Utility Room - Hall appears to have been a porch at one time, later framed in and bathroom/utility rooms added. The floor is composed of short boards which are not preserved well. Many of the boards show deformation due to age and the floor is weak in several places.

5) Bedroom 1 - Long floorboards toenailed into joists. Poorly preserved, rotten in several locations. A trapdoor enters a crawlspace under the floor along the north central wall of the room.

6) Bedroom 2 - Probably a porch or storage room at one time. Floor is composed of small, square boards of varying length, haphazardly nailed down. Most converge on the center of the room where a subfloor support runs east/west across the room. Boards are poorly preserved but not rotten.

7) Bedroom 3 - Floor is similar to that of Bedroom 1 , rotten in several locations.

8) Bedroom 4 - Best floor in the house. Probably laid fairly recently, wax is still present on surface, good preservation of wood, solidly toenailed in place.

Because in most of the rooms the floorboards ran east/ west (except in Bedroom 2 where they ran north/south toward the center), the floor was removed in sections wide enough to place $2-x-2-f t$ units. Ten units were excavated across the rooms in an east/west direction. Each set of units is described by the room in which it was placed.

\section{Living Room}

One 2-x-2-ft test unit was placed in the northwest corner of this room, inside the 1850 s section of the house. The room had been heavily damaged by arson. The area selected for testing was one in which the floor had been burned. One problem was that due to the floor, walls, and roof burning in this section of the house, a large amount of freshly burned debris was present on the ground surface below the floor. The test unit was excavated to a depth of 16 inches below ground surface. The upper 8-10 inches was a brown, sandy fill material mixed with limestone rubble. From there to the end of the unit, was a sterile black clay. A 10-inch probe was done in the northwest corner of the unit and indicated no further stratigraphic changes. The only diagnostic artifact recovered was an early type glass marble known as an "ackro agate" which was produced in the 1920s (Grist 1992; Randall and Webb 1988).

\section{Bedroom 1}

One 2-x-2-ft unit was placed in the northeast corner of this room, inside the 1850 s structure. The unit was excavated to a depth of 15 inches below ground surface. From 0-4 inches was a sandy fill with limestone similar to that encountered in the Living Room. From that point to the bottom of the unit was sterile black clay.

The entire ground surface of this room constituted a crawlspace which was entered through a trapdoor next 
to the central north wall. A large amount of contemporary trash, (wrappers, plastic, cans, etc.) was spread over the surface of the crawlspace. Much architectural debris (plaster, limestone chunks, and wood) was also present. The only artifacts recovered were nails and window glass.

\section{Bedroom 2}

One 2-x-2-ft unit was placed in the northwest corner of this room. Two to three inches of the light brown fill dirt was present overlying sterile, black clay. Artifacts consisted of nails, glass, small animal bone, and metal fragments. A 10-inch probe, conducted in the northwest corner of the unit, showed no stratigraphic changes.

All the floorboards in this room were fairly short and converged on the center of the room. Removal of the floorboards revealed several interesting features associated with the construction and development of the room. At one time the room had only been half its current size. An addition had been made on the south side of the room. The materials comprising the north side of the room all appeared to be fairly old and weathered, while the supports for the south side appeared fairly new and unweathered. A car license plate with the date 1974, found beneath the floor could indicate a period when the floor surface was open.

Photographic evidence from the 1920 s clearly shows the rear section of the house with a room only half the size of the one now present (Rotzler family, personal communication 1991). Under the wooden piers supporting the center of the floor was evidence of a former exterior south wall for the room. Just outside these wall remnants, to the south, a brick surface was revealed running in an east/west direction (house interior, Feature A). Efforts were made to clear off the mostly contemporary debris and fill dirt which covered this brick surface, necessitating the removal of almost all the floor boards in this room. The brick surface itself appeared to date to about 1920-1930 based on the presence of D'HANIS and SECO bricks in the surface. Both brick styles are reported to have been produced in Medina County, Texas, around 1920 (Steinbomer 1983). A SECO brick was also produced in Ohio around 1935 (Gurcke 1987). The surface had apparently functioned as a walkway along the south side of the house approaching an outbuilding that would have been present to the east.

\section{Bedroom 3}

Four $2-\mathrm{x}-2-\mathrm{ft}$ units were placed inside this room, running east/west across the central section. We hoped that if the doorway leading from Bedroom 3 into Bedroom 1 had been present in the original structure, then artifacts distributed in a Brunswick-like pattern as described by South (1977) might be found here.

The easternmost unit exhibited three main stratigraphic zones: 1) a dark mottled silt from $0-2$ inches below surface, 2) a light sandy-colored fill material from 2-8 inches, and 3) sterile black clay from 8-20 inches. Artifacts were primarily glass and cut nails, very low density.

The two central units revealed a series of flat limestone slabs, at a depth of approximately nine inches, running in a northeast/southwest direction. A doll fragment, a small copper jingle bell, cut nails, and several bone fragments were recovered. These limestone slabs may represent part of a walkway in use before the $1880 \mathrm{~s}$ section of the house was constructed. The direction of the edge suggests the walkway would have run around the southeast corner of the house, possibly servicing exits along that side. Moving east it runs in the general direction of a carriage house known to be present on the east side of the lot (see Trench $\mathrm{E}$ above).

The westernmost unit also contained several limestone slabs; however, these appeared to be construction stones rather than paving stones. The matrix of this unit had a fairly high density of charcoal and some butchered bone. Both wire and cut nails were found, along with some bottle glass. One large copper bell reminiscent of the type used on hand-crank telephones was also recovered.

\section{Bedroom 4}

Three 2-x-2-ft units were placed in this room. Units placed on the east and west sides of the room were very similar, showing levels of brownish silt mixed with limestone rubble which overlay a layer of spalled limestone and plaster. At about 8-9 inches, the sterile black clay was encountered. The wall surfaces in this room were noticeably spalling. This is probably due to increased moisture content under the floor created by a floor vent, opening to the outside ground surface, on the far north side of the room. Although a protective barrier was placed around the outside vent, presumably to prevent water from entering, it had 
cracked to the point that water could now flow through the vent under the floor of the house. The central excavation unit showed direct evidence of water flowing across the ground surface. A small watereroded channel ran across the middle of the central unit in the direction of the floor vent; and the ground was saturated to a depth of about 10 inches. If these conditions persisted over a long enough period, then spalling of the limestone wall interiors might be expected. Such a condition could also augment deterioration of the floor and necessitate the installation of a new floor. This could explain why, of all the floors in the house, this one appeared the newest. Artifacts derived from these units consisted primarily of cut nails, bone, window and bottle glass, and architectural debris.

\section{Artifact Group Distributions and Comments}

Table 4-12 shows the artifact group percentages from the site and Figure 4-62 demonstrates the frequency of artifact occurrence across the site. The area of the site which shows the greatest activity is the part of the site which passed through ownership by all three residences on Lots 4 and 5 . The heaviest concentrations of artifacts were derived from an earthen-vault privy (Feature A) located in the southeast corner of Lot 4 . This area would constitute a "family back region" as described by Portnoy (1981), or a peripheral refuse pattern as described by South (1979). Figure 4-63 shows the artifact frequency distributions across the site, from a perspective based solely on shovel test units, rather than $2-\mathrm{x}-2-\mathrm{ft}$ test units. This substantiated the accuracy of the frequency data. When the two spatial frequencies are compared (Figures 4-62 and 4-63), the same general areas are indicated as being heavy-use zones.

\section{BX897 - NCB 621, Lot 7}

Located on NCB 621, Lot 7, 514 and 516 Hoefgen Street, this site was designated 41BX897, the Webb compound. The investigations of this area proved to be the most complex and in many ways the most rewarding of the sites examined during the course of the Alamodome Project. In several ways it demonstrated both the advantages and disadvantages of having historical records to draw upon in excavating an archaeological site.

The original structure to be investigated during Phase II of the project was a small house located at 514 Hoefgen Street. The 1904 Sanborn map showed the structure and indicated that the rear was constructed of adobe. The structure was also pictured in the 1911 and 1952 Sanborn maps, but with no adobe reference (Figure 4-8). An aerial photograph taken during the mid- to late-1950s shows no house present in this

Table 4-12. Site Artifact Frequency Distributions for 41BX896

\begin{tabular}{|l|r|r|l||}
\hline \multicolumn{1}{|c|}{ Group } & \multicolumn{1}{|c|}{$\#$} & \multicolumn{1}{c|}{$\%$} & \multicolumn{1}{c|}{ Notes } \\
\hline Activity & 996 & 5.85 & 307 plastic items; 206 unidentified metal; 192 wire \\
\hline Architecture & 7,614 & 44.75 & 4,426 wire nails; 1,270 cut nails, 915 window glass \\
\hline Arms & 17 & 0.10 & 15 cartridges \\
\hline Bone & 2,021 & 11.88 & \\
\hline Clothing & 353 & 2.07 & 165 buttons; 102 hooks/snaps \\
\hline Furniture & 130 & 0.76 & 91 light bulb frags., 32 lamp parts \\
\hline Kitchen & 5,728 & 33.66 & 4,947 bottle glass frags; 520 ceramics; 214 cans/tops \\
\hline Personal & 157 & 0.92 & 30 pens/pencils; 28 mirror glass \\
\hline \multicolumn{1}{r|r|}{ Total: } & $\mathbf{1 7 , 0 1 6}$ & 100 & \\
\hline
\end{tabular}




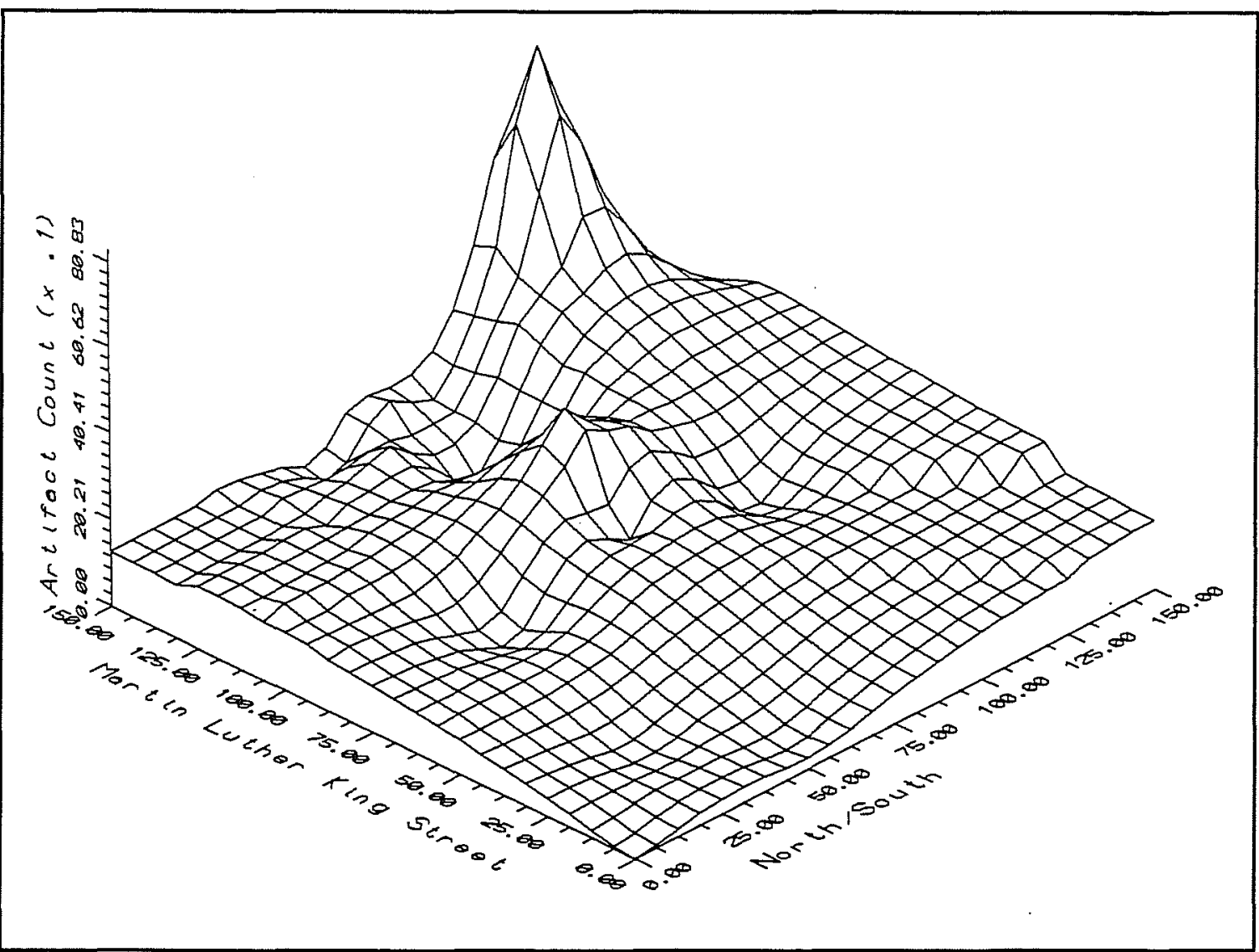

Figure 4-62. 41BX896, spatial frequency across the site.

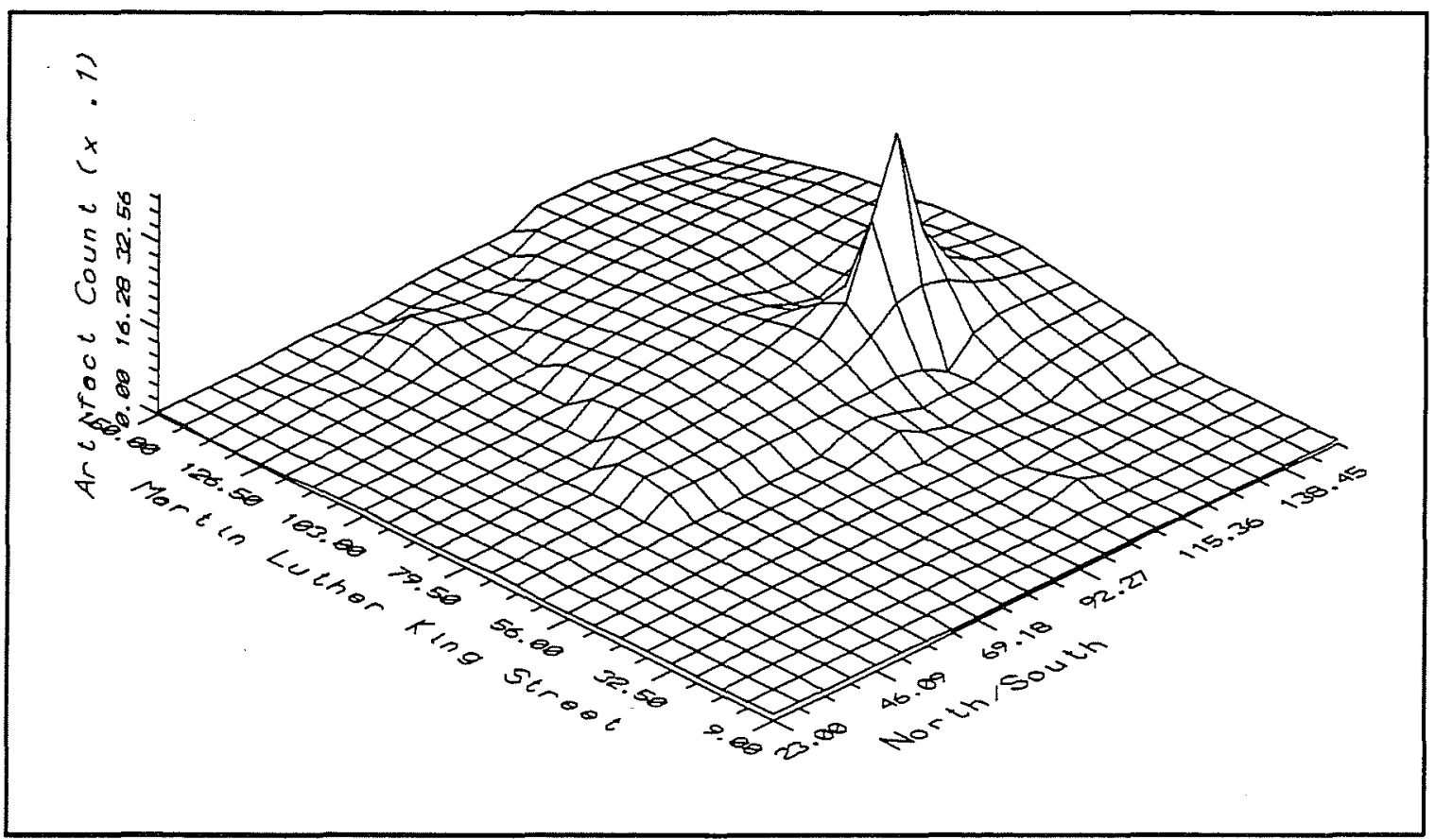

Figure 4-63. 41BX896 spatial frequencies of artifacts based on shovel test data. 
location, so it must have been removed shortly after 1952 (Figure 4-6).

Lot 7 was originally purchased by John Binns in 1860 , and went through several hands until it was sold in April 1866 to Jonathan Hildebrandt (BCDR S1:320, 322, S2:607, 632, U1:207). Hildebrandt was a stonemason and was active in the buying and selling of real estate in and around this neighborhood. It is likely that up until this time no house was present on the site. In May 1866, Hildebrandt sold the property to William and Francis Webb for 75 dollars (BCDR U1:207). During or shortly following this transaction, a home was probably built for the Webbs on the lot by Hildebrandt.

William Webb was an African-American porter, most likely a freed slave who came to Texas from Virginia shortly after the Civil War. Less than one month after purchasing the property, Webb transferred the southern half of Lot 7 to Charles Webb, presumably his brother (BCDR 54:78). The only Charles Webb found in a survey of the city cemeteries was an individual who had served in the 24th Infantry stationed at Fort McKavett in San Saba County (Waynne Cox, personal communication 1991). If this is the same Charles Webb, then he would have been one of the "Buffalo Soldiers" responsible in large part for protecting the frontier during that period. The 24th infantry was one of the all-black regiments stationed at Fort McKavett at that time (Texas Parks and Wildlife 1968).

By 1870 Charles was deceased and his widow Nancy and two daughters were residing in a house south of William Webb's house (516 Hoefgen). In early 1881 Charles Webb's daughter Charlotte married Benjamin Demann, an expressman by trade, and the two continued to live at 516 Hoefgen.

William Webb died in 1885, and the northern half of Lot 7 went to his widow Francis and her son Willis. In 1889 Charlotte and Benjamin Demann purchased the northern half of Lot 7 (BCDR 67:419). At this time a new residence was constructed at 516 Hoefgen, a large L-shaped Victorian structure which appears in the 1904 Sanborn map and continued to exist on the lot until demolished in the 1960 s during construction of a parking lot.
An intriguing mystery presented itself: if the structure shown in the 1904 Sanborn map was not constructed until 1889, and if the Charles Webb family was listed as having resided to the south of William's house, then there must have been an earlier residence. Where was this house? Would any remains be sufficiently preserved to be visible?

\section{Excavations (Figure 4-5)}

The first excavation objective on Lot 7 was to find and expose the remnants of the 10-x-10-ft adobe section of William Webb's house on the north side of the lot at 514 Hoefgen Street. A datum point (elevation $653.21 \mathrm{ft}$ amsl) was established in the southwest corner of Lot 7. Three backhoe trenches and three 2-x-2-ft test units were placed to examine this structure. All work on this structure was performed between September 27 and September 29, 1990. The asphalt surface had previously been removed by demolition crews, revealing a layer of caliche base material underneath.

\section{Trench A}

This trench, $2 \mathrm{ft} \times 59 \mathrm{ft} \times 30$ inches, was placed running north/south across the north part of Lot 7 . The remains of north and south walls of the adobe structure were located at the southern end of this trench.

\section{Trench B}

This trench was placed bisecting the north and south walls to locate the east/west walls shown on the 1904 Sanborn map. The walls were located and, at that point, it appeared we had found all the adobe elements shown on the map. The adobe square measured approximately $16 \mathrm{ft}$ (north/south) by $12 \mathrm{ft}$ (east/west). We decided to fully uncover the walls and in this process revealed that the 1904 Sanborn map definitely did not show all that was present. The Sanborn map shows an adobe rear section, with a frame front component to the house (Figure 4-24).

The excavations revealed that the original house had been constructed completely of stone (Figures 4-64 and 4-65). Apparently the front room of the house had 


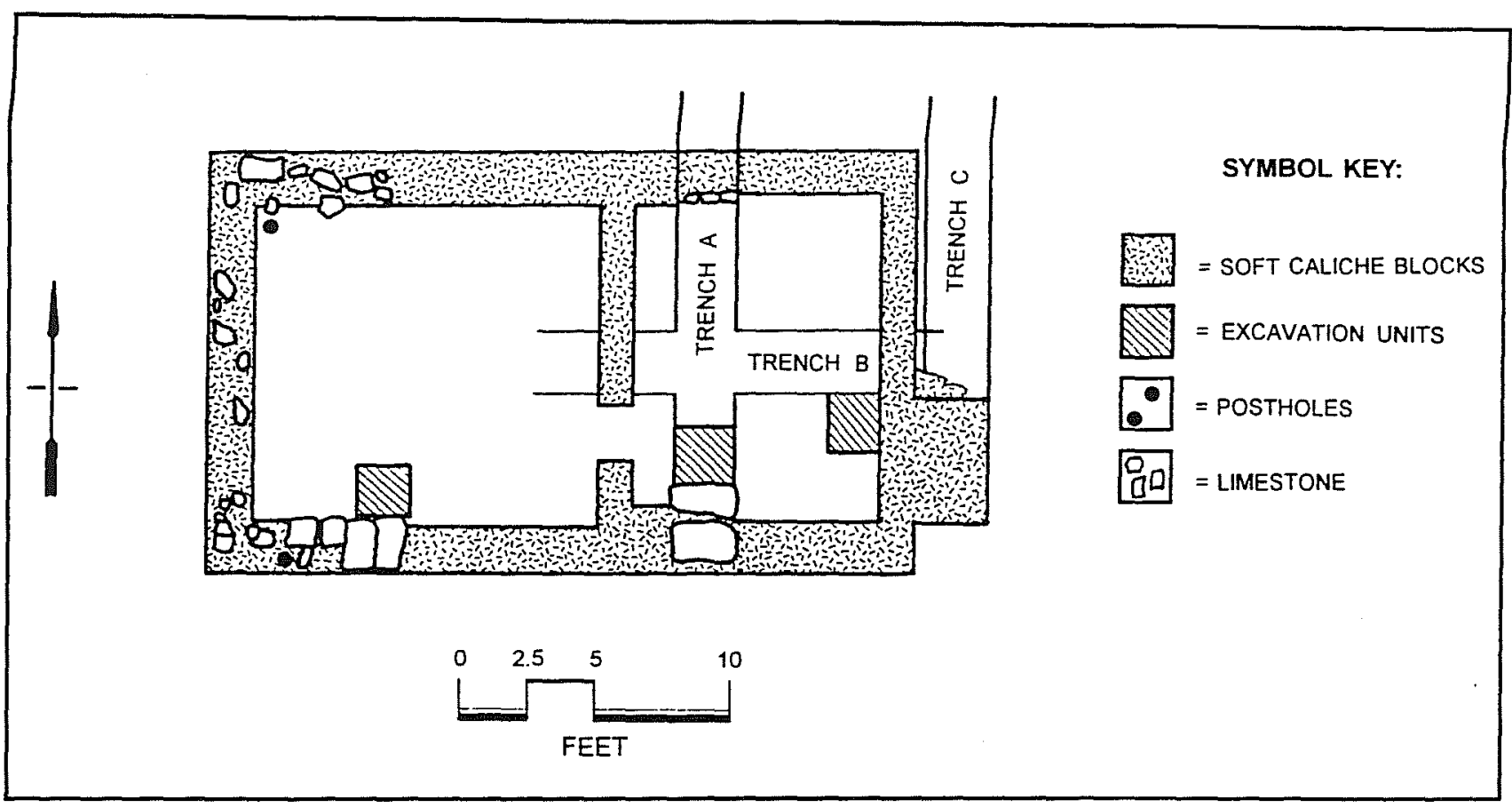

Figure 4-64. Plan map of William Webb House foundation.

deteriorated over time, necessitating the later addition of a frame section. This was evidenced by the presence of postholes in the northwest and southwest corners of the dwelling foundation which intruded into the original foundation blocks and were very poorly preserved in this part of the dwelling. This explains why the 1904 Sanborn map only showed the rear of the house as being adobe.

The original structure was built of limestone and soft, cut caliche blocks and was of the settlement salt-box style. Archival research indicates that Jonathan Hildebrandt was involved in the construction of many homes in this neighborhood Waynne Cox, personal communication 1991). Archaeological investigations suggest that in almost all the cases where Jonathan Hildebrandt was involved, the house was of the settlement saltbox variety. Therefore it appears likely that this house, too, was constructed by Hildebrandt at the time that it was acquired by the Webb family.
The front room of the structure measured $16 \times 16 \mathrm{ft}$. The average thickness of the walls was from 18-24 inches. The two rooms were separated by an interior wall with a doorway, two feet wide, located with its south edge four feet from the outside south wall. A small fireplace hearth, measuring $4.5 \times 2.5 \mathrm{ft}$, was discovered along the east wall with its south edge two feet from the southeast corner of the foundation.

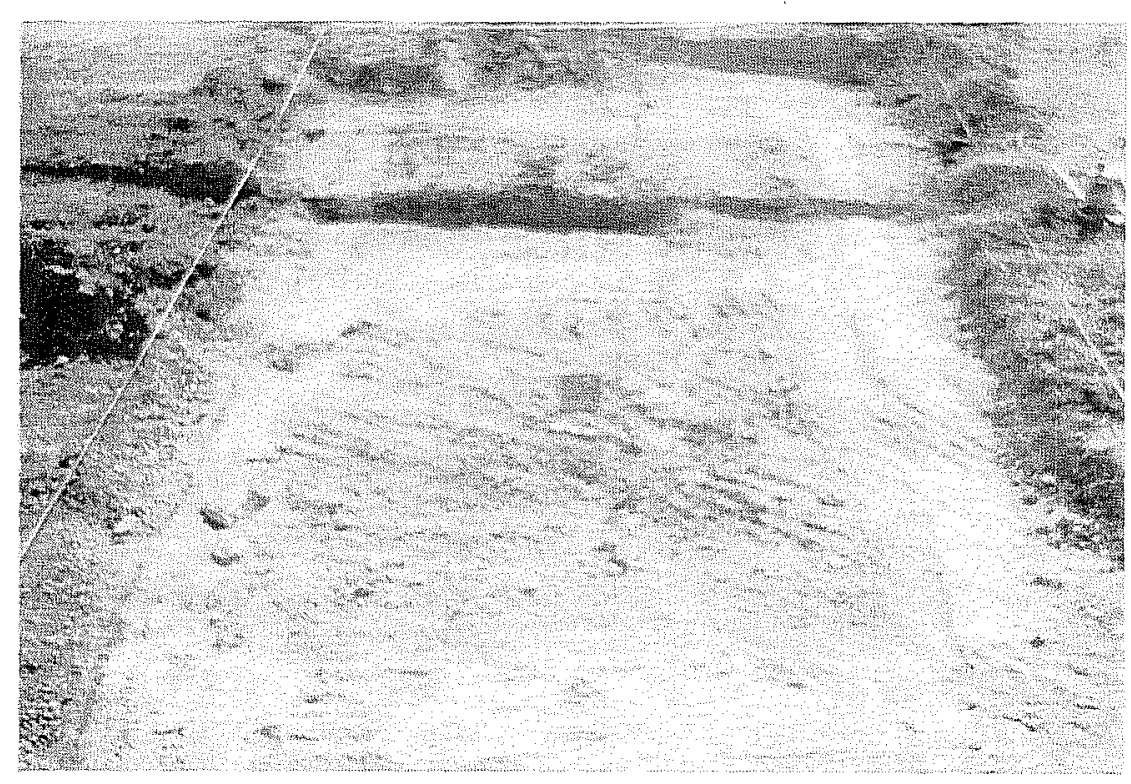

Figure 4-65. Foundation of the William Webb House. 


\section{Trench C}

This trench, measuring $2 \times 12 \times 3 \mathrm{ft}$, was placed adjacent to the east wall running north from the north side of the fireplace hearth. This was done to test the depth of the foundation remains, which was found to vary from 4.5-9 inches. The primary construction component was soft, cut caliche blocks laid on a slightly wider footing of limestone cobbles. Bulldozing for the placement of the asphalt surface had probably removed all the living surfaces from outside this structure. Three 2-x-2-ft test units were placed within the structure to examine the extent of any living surface that might remain. Two of the units were put in the east room and one in the west. Most of the artifacts recovered were in secondary context and no living floor was present.

Once the location of this northern structure was established, investigations proceeded to the southern half of Lot 7 to search for the suggested early dwelling of Charles Webb, as well as to examine the remains left by his son-in-law (Demann) and his family. The first part of this work was carried out between October 10 and 22, 1990. Eight backhoe trenches were placed over the southern area of Lot 7. Four of the trenches (D, E, F, and G) were oriented north/south, and four ( $G, H, I$, and $K$ ) east/west. Trench I was very wide (about $12 \mathrm{ft}$ ), and encompassed the area between the north wall of Trench $\mathrm{G}$ and the south wall of Trench $\mathrm{H}$ (Figure 4-5).

\section{North/South Trenches}

\section{Trench D}

We decided to search for Charles Webb's early house on the south side of the lot directly opposite William Webb's house. Benjamin Deman had constructed a dwelling in this location in 1889; therefore, if Charles Webb had a dwelling here, it probably would have been razed before construction on the later structure began. A mixed-context deposit, with remains from both structures, would be expected in such a case.

Trench D was placed in a location that would bisect a structure from north to south if the structure were placed directly opposite William Webb's house on north Lot 7. The trench measured $2 \times 45 \mathrm{ft}$. Three cedar posts were encountered, one at $13 \mathrm{ft}$ south and two at $26 \mathrm{ft}$ south. At $41.2 \mathrm{ft}$ south, a 1.5 -inch waterline crossed the trench east/west. From 13-21 ft south, a white plaster surface was encountered; this material was also present surrounding the posts at $26 \mathrm{ft}$ south. The surface was exposed and left in place while the other backhoe trenches were excavated.

\section{Trench E}

This trench was started seven feet east of Trench D and measured approximately $2 \times 49 \mathrm{ft}$. Two 1.5 -inch water pipes were encountered at eight feet south. From $10-38 \mathrm{ft}$, south a plaster surface similar to that encountered in Trench $D$ was exposed. A cedar post was present in the west profile at about $25 \mathrm{ft}$ south. The plaster surface was cleared off and left intact while further trenches were placed. From $40-46 \mathrm{ft}$ south, heavy artifact concentrations were encountered, including blue incised edgeware sherds dating to the mid-1800s (Tennis, Volume III).

\section{Trench F}

This trench was started approximately $15 \mathrm{ft}$ west of Trench D. At eight feet south, two 1.5-inch water lines were revealed. At about $18 \mathrm{ft}$ south, the plaster surface was encountered; however, it was badly deteriorated and very thin. It appeared to taper out in this location.

\section{Trench J}

Since the plaster surface appeared to terminate in the central portion of Trench $F$, Trench $J$ was placed between Trenches $D$ and $F$ to further define the shape of this unusual surface present in the other trenches. A cedar post was found at five feet south in the trench, at 15-31 inches depth. At $5 \mathrm{ft} 4$ inches, a second post was found at 16 inches below ground surface. At four feet south and 20 inches depth, an eight-inch diameter post mold was found filled with a light marl/clay fill, this mold continued to a depth of 26 inches. Starting at six feet south and running to $16 \mathrm{ft}$ south, the plaster surface was encountered.

What now appeared in plan view of the four north/ south trenches (D, E, F, and J) was a plaster surface forming a rough $L$-shape with the axes meeting to the northeast (Figures 4-66 and 4-67). In several locations the surface of the plaster appeared to have been laid in more than one layer, and to have been patched in several locations (Figure 4-68). Since the shape of the surface did not conform to that of the later 1889 dwelling that was in this location, and since there was 


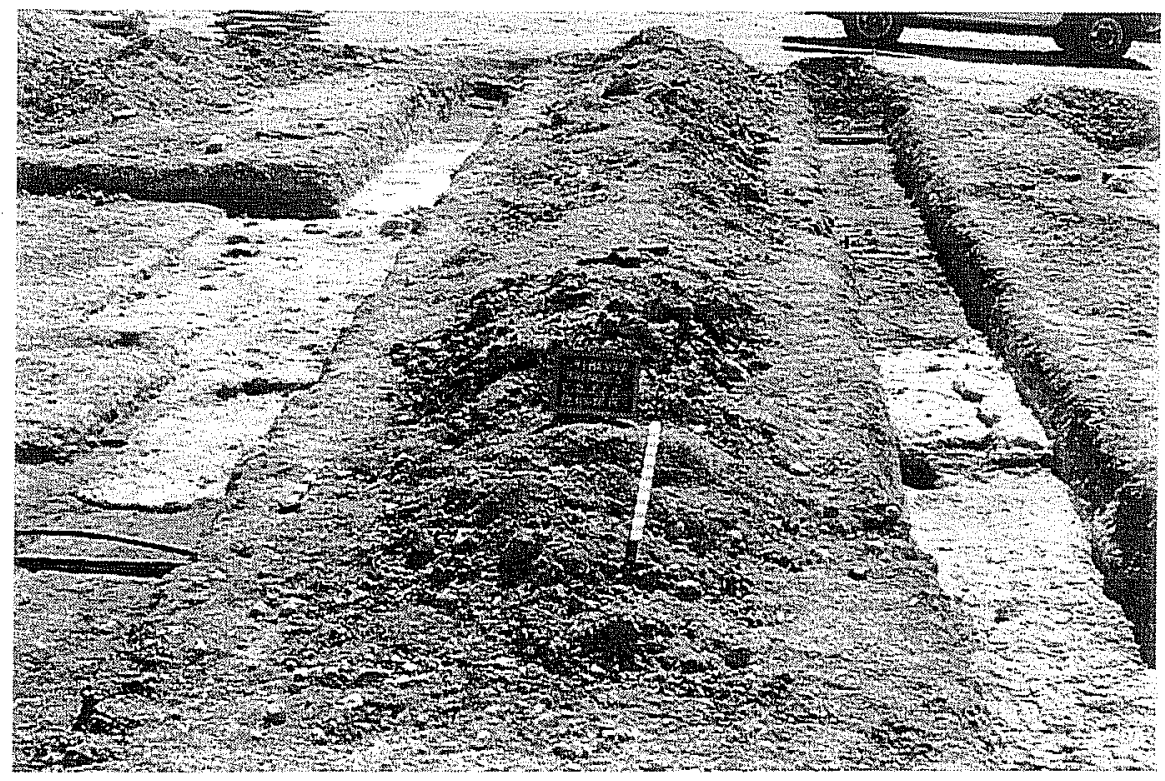

Figure 4-66. Plaster floor of Charles Webb House.
$30-40 \mathrm{ft}$ east was placed, and a 4- $\mathrm{x}-10$-ft south extension running from $36-46 \mathrm{ft}$ east was implemented. The walkway appeared to be about $14 \mathrm{ft}$ long. Eleven feet east of its beginning, an intrusion had been cut through the walkway for the placement of a 1.5-inch water pipe. The bricks were various colors (yellow, red, orange, and pink) and were interspersed with limestone cobbles. The latter were placed primarily along the outside margins of the walkway. Just north of the walkway was a plaster surface, about one inch thick, extending beyond the margins of the trench extension, this would be investigated later. evidence of earlier posts which had been removed from this location, the surface was likely the interior floor (albeit poorly preserved) of an earlier structure.

The structure would have measured $25-30 \mathrm{ft}$ east/west and 25-30 ft north/south. Average width would have been from 10-12 ft. An awning or porch may have been present on the southwest corner of the structure. Although this area was not plastered over, a series of posts exhibiting a light-colored fill, inconsistent with the fill associated with the posts from the 1889 structure, was present (Figure 4-67).

\section{East/West Trenches}

\section{Trench G}

This trench ran east/west starting on the east profile of Trench E at approximately $25-27 \mathrm{ft}$ south. At 8-9.5 ft east a thin plaster layer (much thinner than the previously mentioned floor surface) was encountered. At $29 \mathrm{ft}$ east a brick surface was uncovered. The bricks appeared to cross the trench at an angle running northwest/ southeast. The width of the surface appeared to be two feet (relative elevation 652.6 ft amsl) (Figure 4-69).

We decided to put two lateral extensions on Trench G to explore what appeared to be a brick walkway (Feature B). A 4-x-10-ft north extension running from

\section{Trench H}

Starting $11 \mathrm{ft}$ south in Trench E, on the east profile, this east/west trench was designated $H$. This trench was $2 \times 47 \mathrm{ft}$. Approximately $28-43 \mathrm{ft}$ east, a thin plaster deposit similar to one encountered just north of Feature B was revealed. We decided to follow this deposit to the north, so a trench extension (Extension $\mathrm{H}$, North) was made from $25-43 \mathrm{ft}$ east in the trench running 6-14 ft north of Trench $\mathrm{H}$. The plaster surface continued to the north, eight feet from Trench $\mathrm{H}$, creating a rough square $10 \times 13 \mathrm{ft}$. The surface of the plaster had been cut by a water pipe intrusion on its south side, creating a break approximately two feet wide.

\section{Trench I}

We decided that to fully understand the extent and purpose of the thin plaster surface in this location, a wider area of exposure would be required. Trench I was implemented, removing the entire area between the south side of Trench $\mathrm{H}$ and the north side of Trench G.

Since we were now familiar with the depth of the caliche fill-zone under the asphalt parking lot, we could allow the backhoe to open up a wider area, providing greater access for hand excavation in what was perceived to be the back yards of both the Charles Webb and Benjamin Demann residences. The strategy 


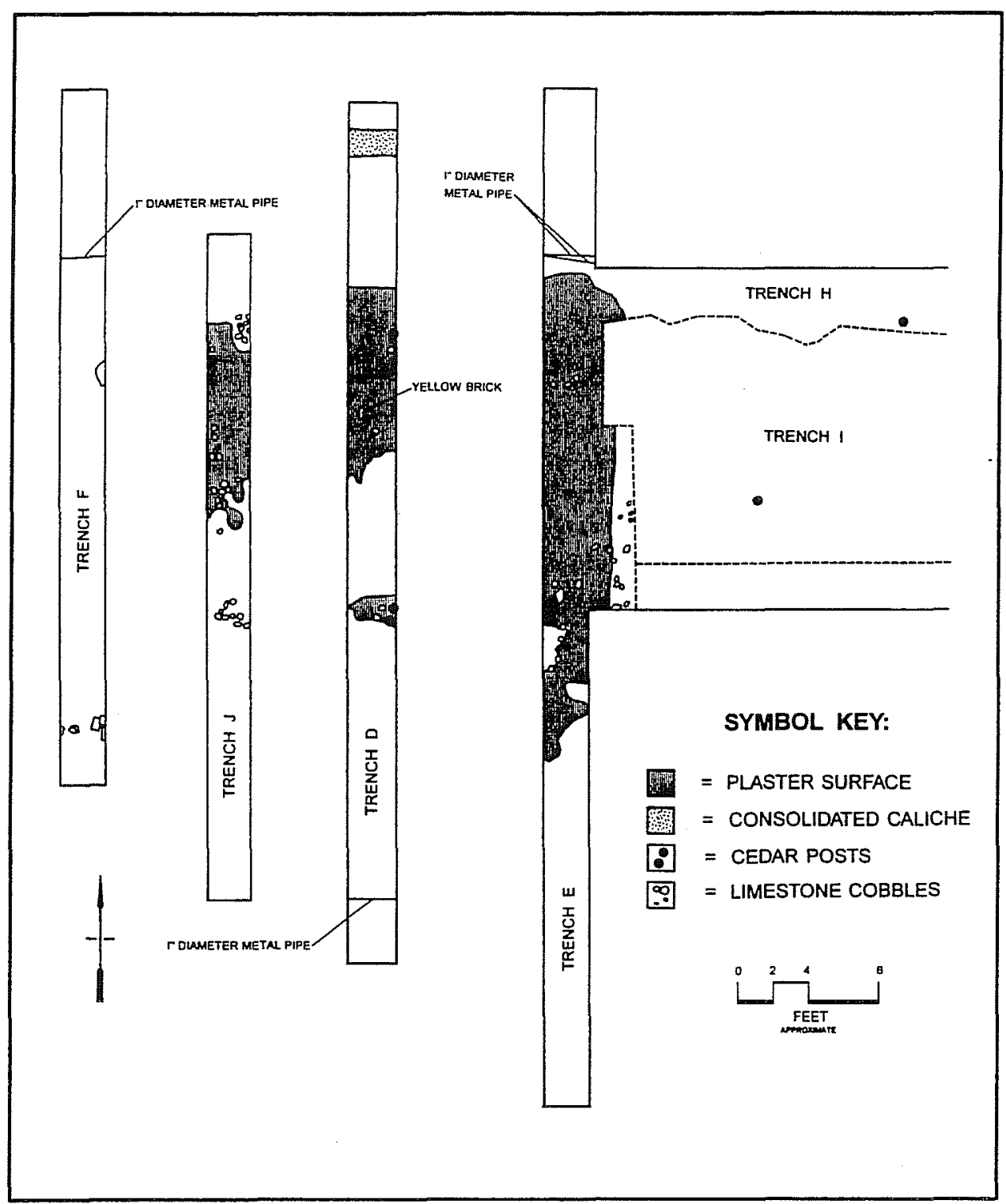

Figure 4-67. North/south trenches excavated on $41 B X 897$ (south). dated the construction of the 1889 house since it was positioned under the northeast corner where the later house had stood. One of the cedar past supports for the 1889 house was actually placed in the center of the well fill surface. The well surface was cleared off and we decided that the interior of the well would be further investigated at a later date (Figure 4-70).

The area of Trench $I$ from 18-47 $\mathrm{ft}$ east was hand excavated to a depth of 12 inches. This area yielded a high density of sheet refuse, mainly associated with the kitchen group of artifacts (also bone, oyster shell, and bottle and window glass). A 10-ftwide area void of plaster was found to exist between the north edge of the plaster located near Feature B and the south edge of the plaster revealed in Trench $H$. A large post mold was found midway between these two plaster surfaces. A small structure had probably been located in this void involved starting on the east profile of Trench $E$ between Trenches $\mathrm{G}$ and $\mathrm{H}$. All caliche parking lot fill would be removed down to the darker clay natural surface which existed below the fill dirt. The trench would be continued out to the full length of Trenches $\mathrm{G}$ and $\mathrm{H}$ (approximately $47 \mathrm{ft}$ east). The area from 0-18 ft east received little hand excavation; however, several posts associated with the rear section of the 1889 structure were identified. One suspicious area of limestone rubble surrounding some of these posts was excavated (Feature A). This rubble turned out to be the material fall from the above-ground portion of a handdug limestone well (Feature E) discovered six feet to the east of this point. The circular well obviously pre- area (Figures 471 and 4-72); the thin plaster surface was the result of yard management and sweeping around the structure. The structure could have been an external kitchen, due to the high incidence of kitchen artifacts and bone in this area, as well as its proximity to the water well. This area was redesignated Area A. An 1857 dime was found on top of the southwest corner of the north side plaster surface, approximately four feet east of the well (Feature E).

\section{Trench K}

This trench was placed to search for the remains of outbuildings along the south boundary line of Lot 7 . The 1904 Sanborn pictured one outbuilding in this 


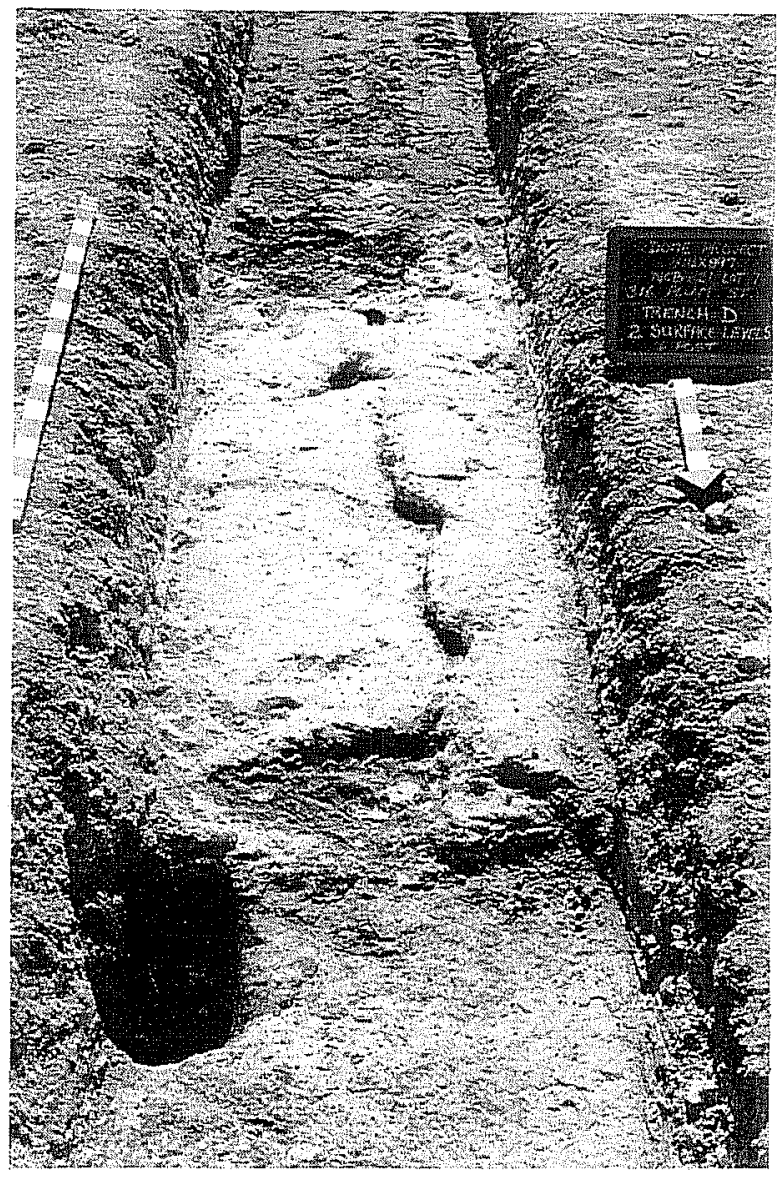

Figure 4-68. Plaster surface of Charles Webb House, laid in several layers.

area, while the 1911 Sanborn pictured a small compound of three outbuildings. The west end of the trench was located approximately N5E81 from the datum point. The trench ran $53 \mathrm{ft}$ to the east of its starting point. Artifact density was high throughout the trench. From 0-15 ft east, many items associated with personal cleanliness were found, including drinking glass fragments, shaving mug fragments, and a sign with "SOAP" written on it. At $18 \mathrm{ft}$ east, three large limestone pavers crossed the trench north/south (Feature C). To the east of this alignment, the nature of the soil changed dramatically to a very loamy brown soil with an unmistakable smell of horse dung. Several horse- and tack-related items (horse and mule shoes, buggy parts) were recovered in this area. A cedar post was located in the north wall profile at $37.5 \mathrm{ft}$ east. Final dimensions for the trench were $2 \times 53 \times 2 \mathrm{ft}$.
The artifactual and stratigraphic remains indicate at least two outbuildings within this zone. One may have functioned as a wash area, the other as a stable.

Phase II work was completed on this site on October 22,1990 . There was to be a significant delay between the end of this phase and the beginning of demolition monitoring (Phase III). Since we had decided to mitigate the well feature (E), and since the whole site was located next to the footprint for the dome construction (actually on what was to be the entrance ramp for the demolition equipment), it was essential to carry out mitigative excavations as quickly as possible. Special provision was made within the Phase III budget to cover the further excavation of this site. In the interim, to protect the areas which would be further excavated, the well and the area surrounding it were covered with sheets of thick black plastic and barricades were placed around the site.

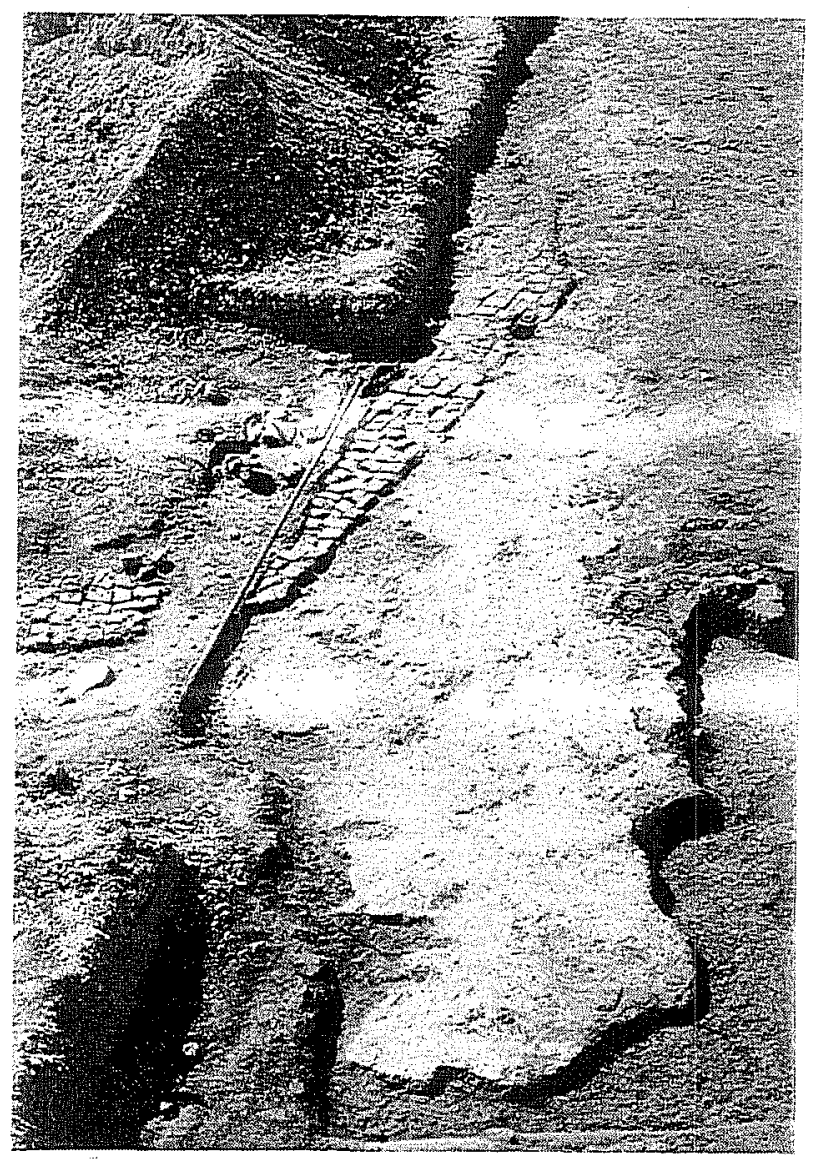

Figure 469. Brick walkway and south side of plaster surface (kitchen). 


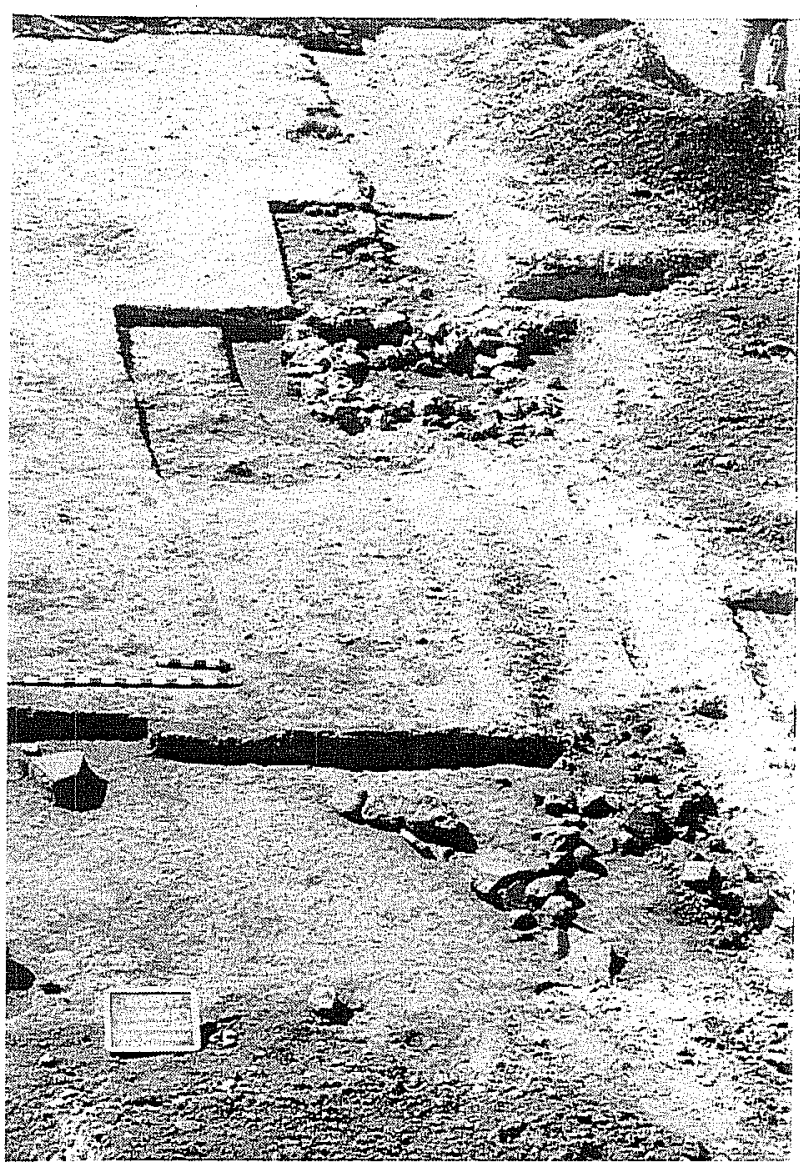

Figure 470. Limestone well surface and north side of plaster surface (kitchen).

\section{Phase III Excavation of Feature E and Surrounding Area}

Phase III work at 41BX897 began on December 5 and ran to December 20,1990. We had decided to section the limestone well (Feature E), removing the south side and leaving the north side in profile (Figure 4-73). This operation was similar to work done at 41BX930 the week before and to the excavation of a well in 1985 at Mission San José (41BX3) (Taylor 1985). Several major differences were present, however. At 41BX930 much of the upper section of the well had been removed already because the well had not been filled and was located solidly within the footprint of the Alamodome construction. Demolition crews had been removing the soil within the footprint to a depth of about $10 \mathrm{ft}$ below the surrounding ground surface. Therefore no cultural layers were present in the soil surrounding the well at $41 \mathrm{BX} 930$ when it was excavated. In the case of the well at $41 B \times 897$, we would be starting excavations at a point very close to what had been the existing ground surface at the time the area was covered for a parking lot, so we expected a significant deposit of artifacts based upon what had been revealed during Phase II operations on this site.

A 23-ft-wide approach lane would be excavated to provide ample space for the crew to work on the well face and to give sufficient safety from slumping. A sloping trench would angle down to the well face to provide access for the backhoe; this trench would become longer as progress was made to deeper levels. Since we expected to reveal artifacts and features during the trench expansion, a methodology for provenience control was developed to allow investigation of the soil as the approach trench was excavated, yet not significantly slow down the backhoe in the construction of the approach trench.

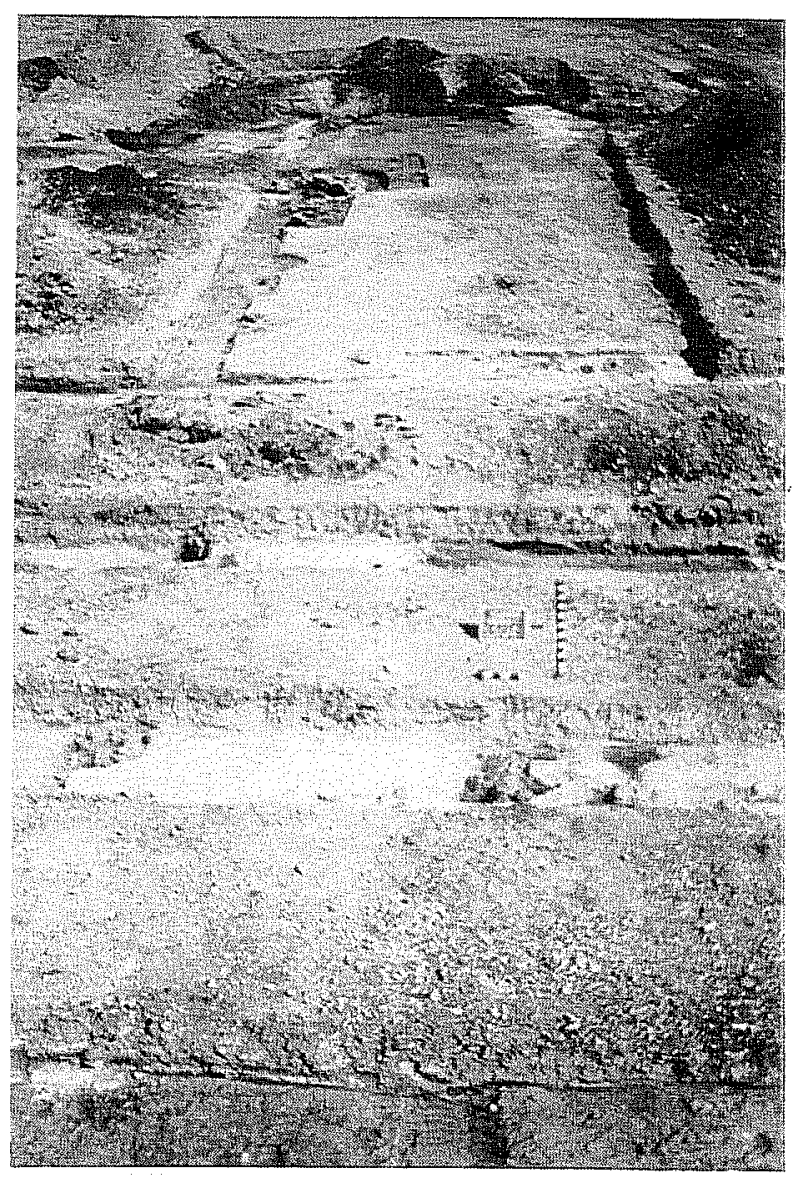

Figure 4-71. Plaster outline of small structure (top) in southeast area of $41 B \times 897$. 


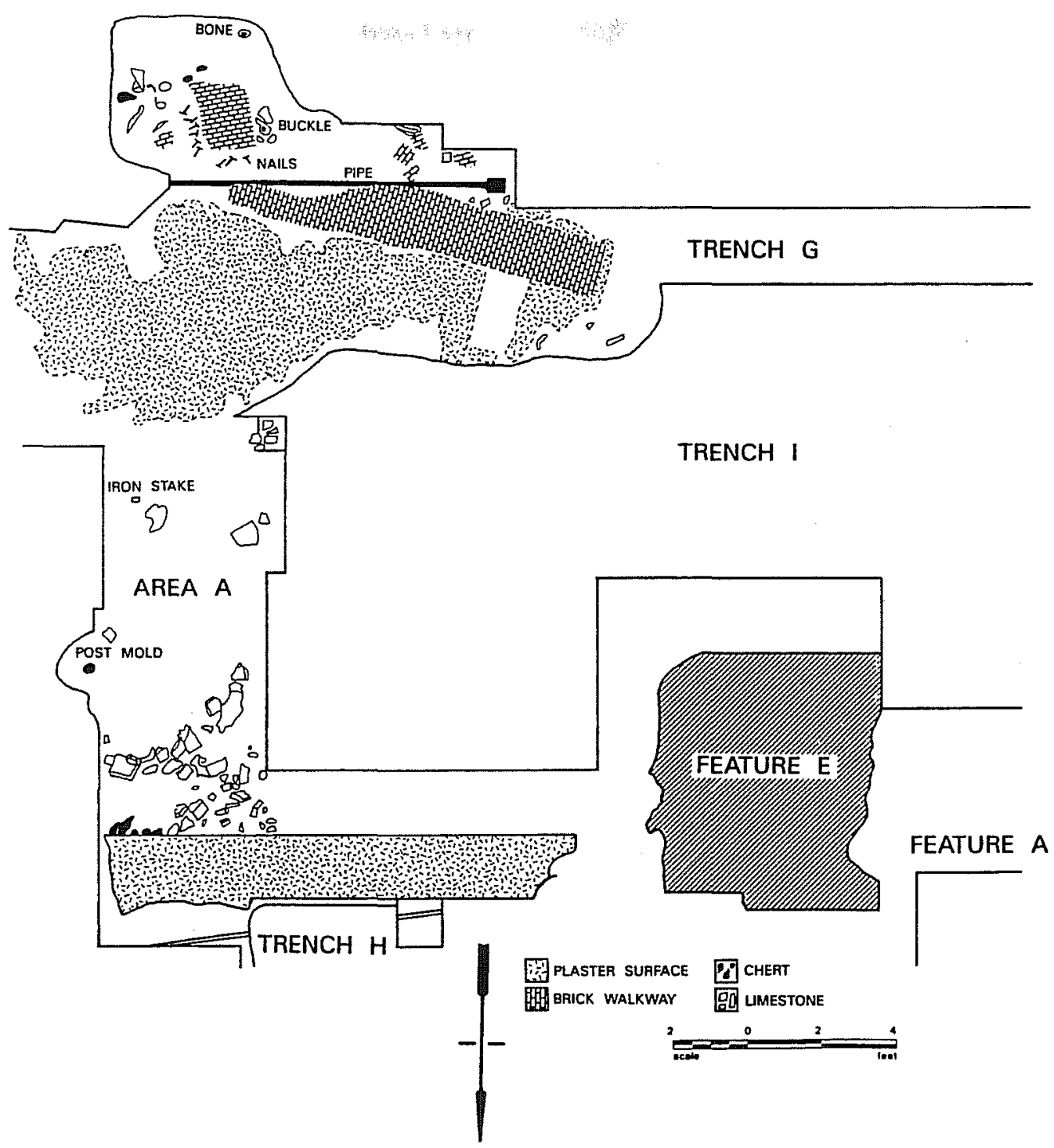

Figure 4-72. 41BX897, plan view of southeast section.

Each block section opened by the backhoe was called a "well expansion trench" (WET \#). Three of these were required to fully expose the well. Within each WET was a series of 9 or 10 smaller trenches excavated in the process of constructing the larger overall trench. Each of these smaller trenches was called a "cut" (Cut \#) and was numbered. Within each cut provenience was kept by scoop (Scoop \#), with each scoop being about five inches in depth. All soil excavated from the expansion trenches was carefully monitored by crew members and volunteers.
In its final form, the overall expansion trench measured $23 \times 41 \mathrm{ft}$, with a maximum depth of $13.5 \mathrm{ft}$ (Figure 4-74). Cultural material was present from just below the caliche fill-zone for the parking lot (0-14 inches deep). Below this was a sterile black matrix of a similar, but slightly more compacted, nature which continued to $4.9 \mathrm{ft}$ below ground surface. At this point a stratigraphic change to an orange/tan caliche soil (Pleistocene gravels) occurred. The water level was encountered at a depth of approximately $13 \mathrm{ft}$. 


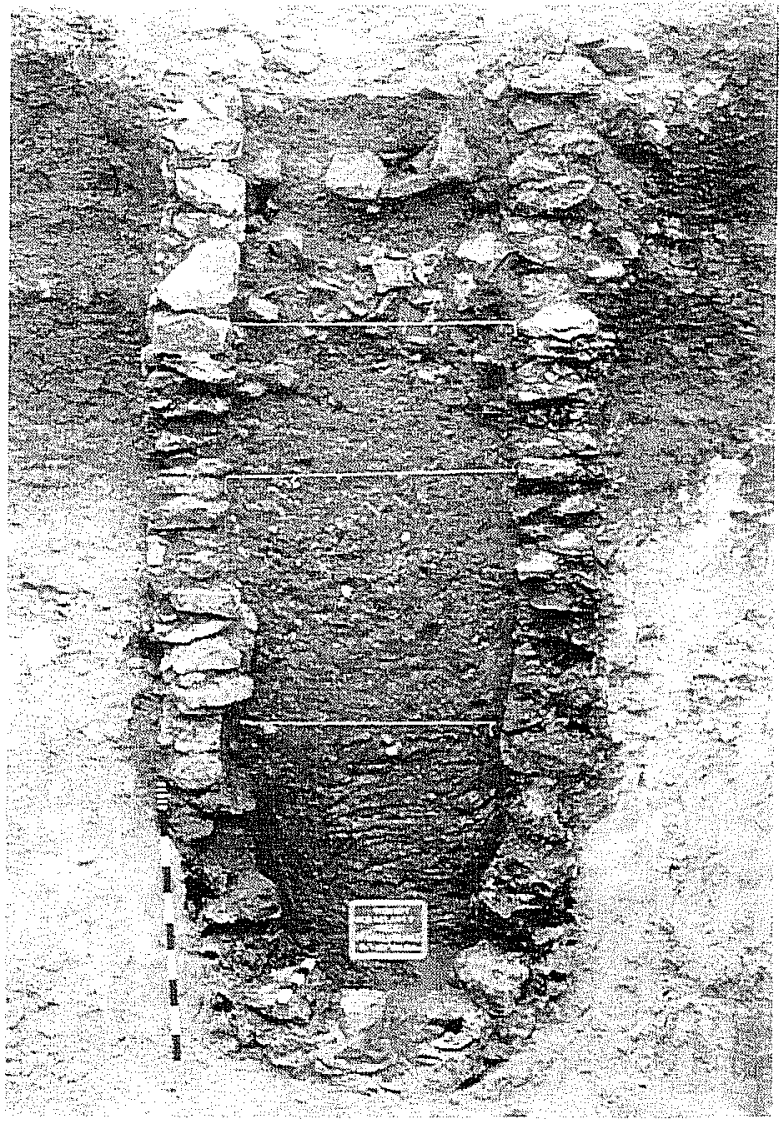

Figure 4-73. 41BX897, completed well profile.

The most interesting evidence revealed by the expansion trench excavation was the fact that the Webb/Demann family were using the adjacent lot to the south (Lot 9 - 41BX883), which they never owned. As the overall expansion trench grew in length it crossed over the boundary line between Lots 7 and 9 at a point just after the start of WET \#2 (13 ft south). What was surprising was that there was no significant break in the heavy density of the sheet refuse encountered in this area. Within WET \#2, seven cedar posts were discovered representing the south side of an early outbuilding complex well into Lot 9. Also surrounding this compound of outbuildings was a thin layer of swept plaster similar to that found surrounding the small kitchen outbuilding by the well itself. The well was sectioned with the north side left in profile and the south side excavated and screened through 1/4-inch mesh. Eleven levels were excavated starting at 16 inches below ground surface and running to 144 inches where water was encountered (Figure 4-73).
The well appeared to have been filled over a very short period of time. The top $4.5 \mathrm{ft}$ exhibited distinct strata containing architectural refuse (window glass, tile, cut and wire nails, metal fragments, and brick fragments). From that point to the bottom of the well was a single grayish fill zone that appeared to have been introduced within a single episode. Most of the artifacts derived from the well interior were architectural in nature. Some oyster shell, bone, and egg shell were collected. One piece of blue crow's-foot edgeware was recovered from the material composing the well structure itself (from between the limestones, Figure 4-75). This type of edgeware was produced between 1820 and 1845 (Moir 1987b).

Ceramic sherds dating to well before the first recorded resident of Lot 9-Cornelius King, around 1884-were found over about two-thirds of that site, along with a limestone structural foundation for which there is no archival documentation. Based on the present data, the Webb/Demann family was working and living on both Lots 7 and 9, and site overlap between the two lots is certain. Most of the buildings previously present on Lot 9 were probably razed before or shortly after King acquired Lot 9 in 1884.

\section{Artifact Group Distributions and Comments}

This site produced the highest density of sheet refuse of all sites examined during the project. Table 4-13 shows the artifact group percentages for the site. The areas behind the primary dwellings and around outbuildings were the heaviest utilized of the site. About two-thirds of the site was covered by asphalt; however, in this case the asphalt surface had not significantly disturbed the living surfaces below. The overlap of this site with 41BX883 created a problem with overall totals for artifact groups, as about onethird of the site was actually present on 41BX883. However the sheet refuse appeared to be fairly consistent in both form and content over the entire area and for the purposes of this study the artifact totals derived were confined to Lot 7 . 


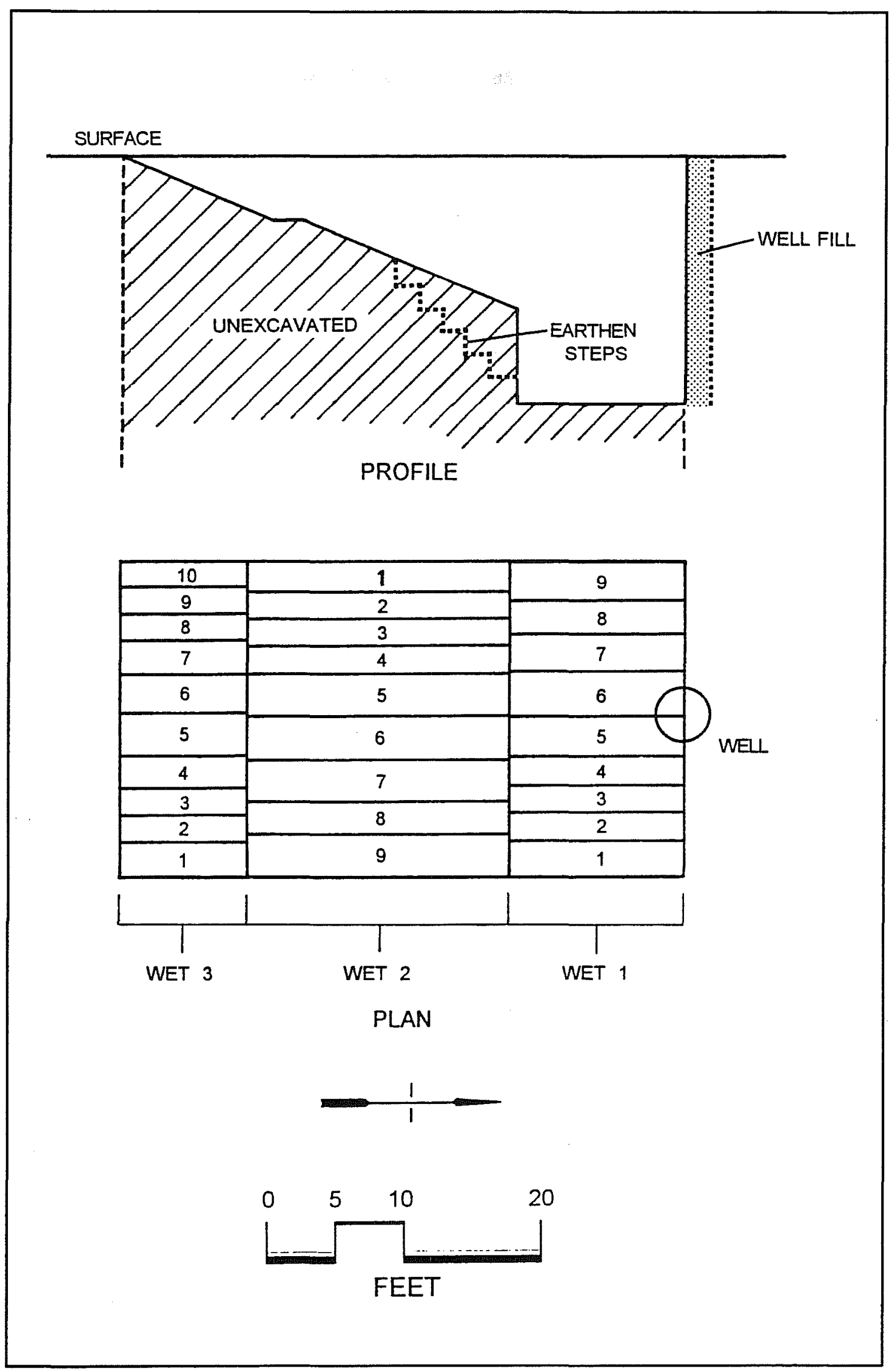

Figure 4-74. Expansion trench excavated to approach well face. 


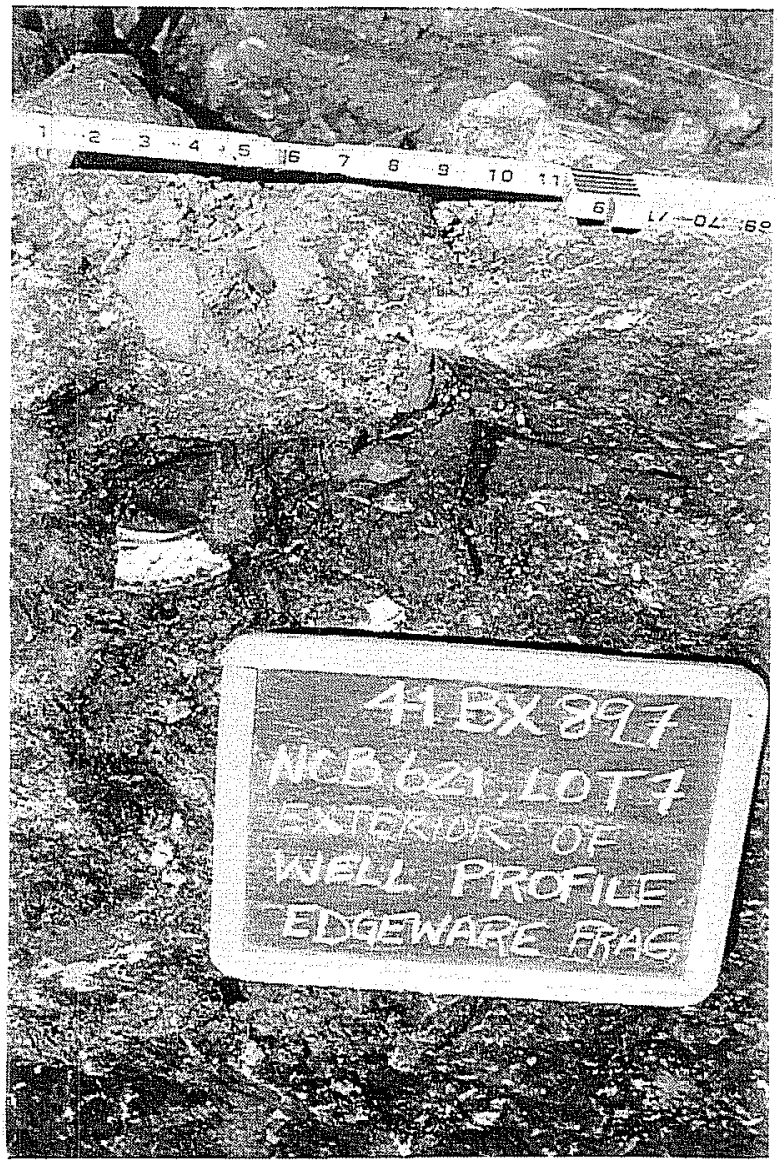

Figure 4-75. Blue crow's-foot edgeware from material composing the well structure.

\section{$41 \mathrm{BX} 900$ - NCB 622, Lot 6}

The Gordon site, 41BX900, is located on NCB 622, Lot 6,305 Nevada Street. Lot 6 was later subdivided down to Lot A11. The Gordon site occupies the southwest corner of the block (Figure 4-76).

This property was acquired in 1859 by Charles $\mathrm{H}$. Gordon, for whom the site is named. It was during this period that the small settlement salt-box dwelling was probably built (Figure 4-77). In 1870 the property was sold to Gottlieb Glaeser, who owned several other lots in the neighborhood and resided on the same block just to the east (313 Nevada). Gottlieb gave this residence to his daughter Fredricka (BCDR H2:281, S1:379, V2:554, W2:118).

The 1904 Sanborn map shows two dwellings on Lot A11: a frame dwelling located on the corner of Walnut and Nevada streets (301 Nevada), and a small adobe dwelling at 305 Nevada on the east side of the lot (Figure 4-78). No outbuildings are pictured. The situation is identical in the 1911 Sanborn map. Southwestern Bell Telephone Company acquired the property around 1925. By the time the 1952 Sanborn map came out, the whole area is pictured as a materials yard for Southwestern Bell. At the time archaeological investigations started in 1990, the lot was still owned by Southwestern Bell and was being used as an employee parking lot. The whole site was covered by asphalt.

Table 4-13. Site Artifact Frequency Distributions for 41BX897

\begin{tabular}{|c|c|c|c|}
\hline Group & $\#$ & $\%$ & Notes \\
\hline Activity & 417 & 3.13 & 153 unidentified metal items; 100 misc. metal \\
\hline Architecture & 4,066 & 30.53 & 2,464 cut nails; 1130 wire nails \\
\hline Arms & 15 & 0.11 & 8 shotgun shell casings; 7 cartridges \\
\hline Bone & 4,626 & 34.74 & \\
\hline Clothing & 157 & 1.18 & 122 buttons \\
\hline Furniture & 39 & 0.29 & 18 flower pot frags.; 9 furniture parts; 6 lamp parts \\
\hline Kitchen & 3,901 & 29.30 & 2,409 bottle glass frags.; 1,420 ceramics \\
\hline Personal & 95 & 0.71 & 54 slate frags. \\
\hline Total: & 13,316 & 100 & \\
\hline
\end{tabular}




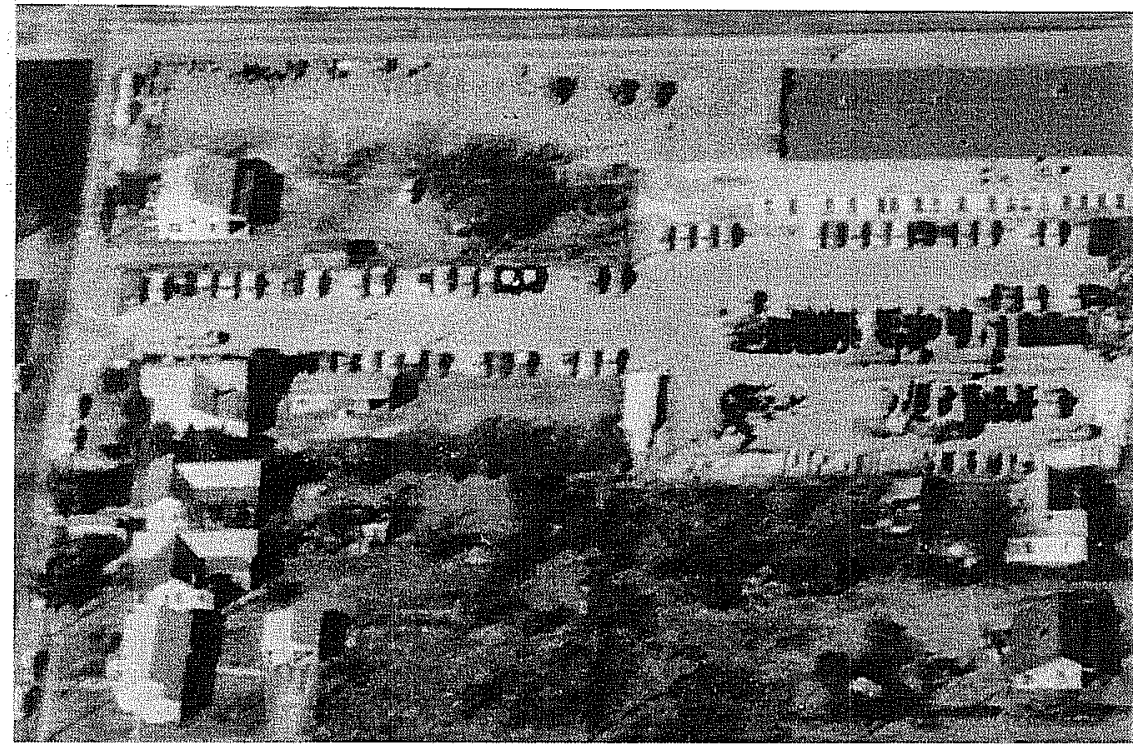

Figure 4-76. NCB 622 (41BX900), top. Facing west

wall of the structure when it became evident that 50 percent of the area where the structure had been located was covered with an eight-inch-thick concrete slab. This was too thick and large for our backhoe to break or lift. There was no way to know if the foundation was still intact beneath the concrete slab, therefore the second trench was put in a north/south orientation to find the north wall of the structure as it came out from under the concrete.

Trench B was eight feet long and the north wall of the structure was discovered about two feet north into the trench. One artifact was found in this trench, a circular

\section{Excavations (Figure 4-79)}

Subsurface work was done at 41BX900 in two phases. On October 19, 1990, Phase II operations were carried out on the site. The primary objective of this operation was to determine whether any foundation elements for the adobe structure which occupied the lot still remained beneath the surface of the asphalt. We decided that if a foundation was present, then the backhoe trenches would be backfilled and the site would be explored in depth during Phase IV mitigations.

Two trenches were cut through the asphalt in search of the foundation. Trench A was a 14-ft east/ west trench placed to find the west wall of the structure. The trench placement was based on the 1904 Sanborn map. At approximately five feet west in the trench, the west wall of the structure was encountered. A second trench (B) was excavated to locate the east

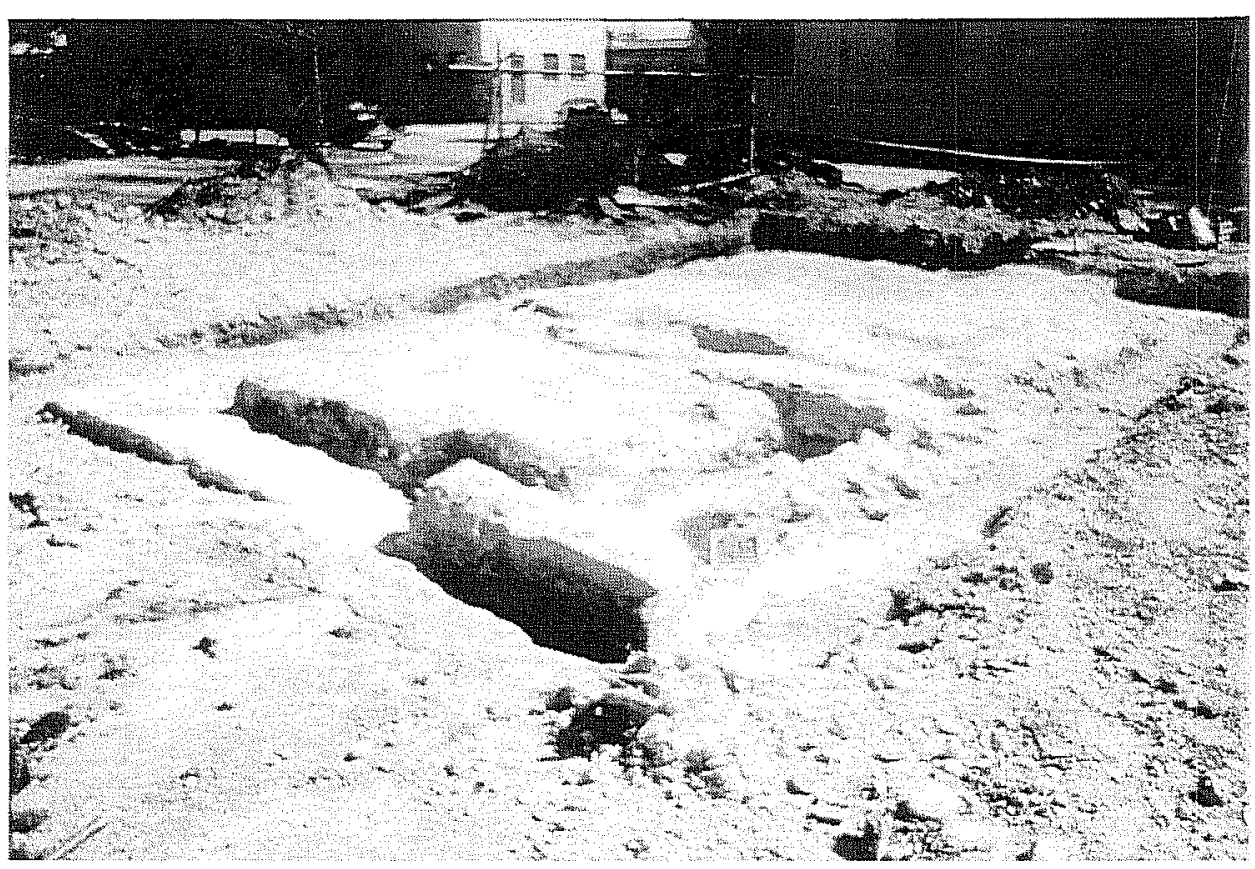

Figure 4-77. Foundation of the Gordon House. 


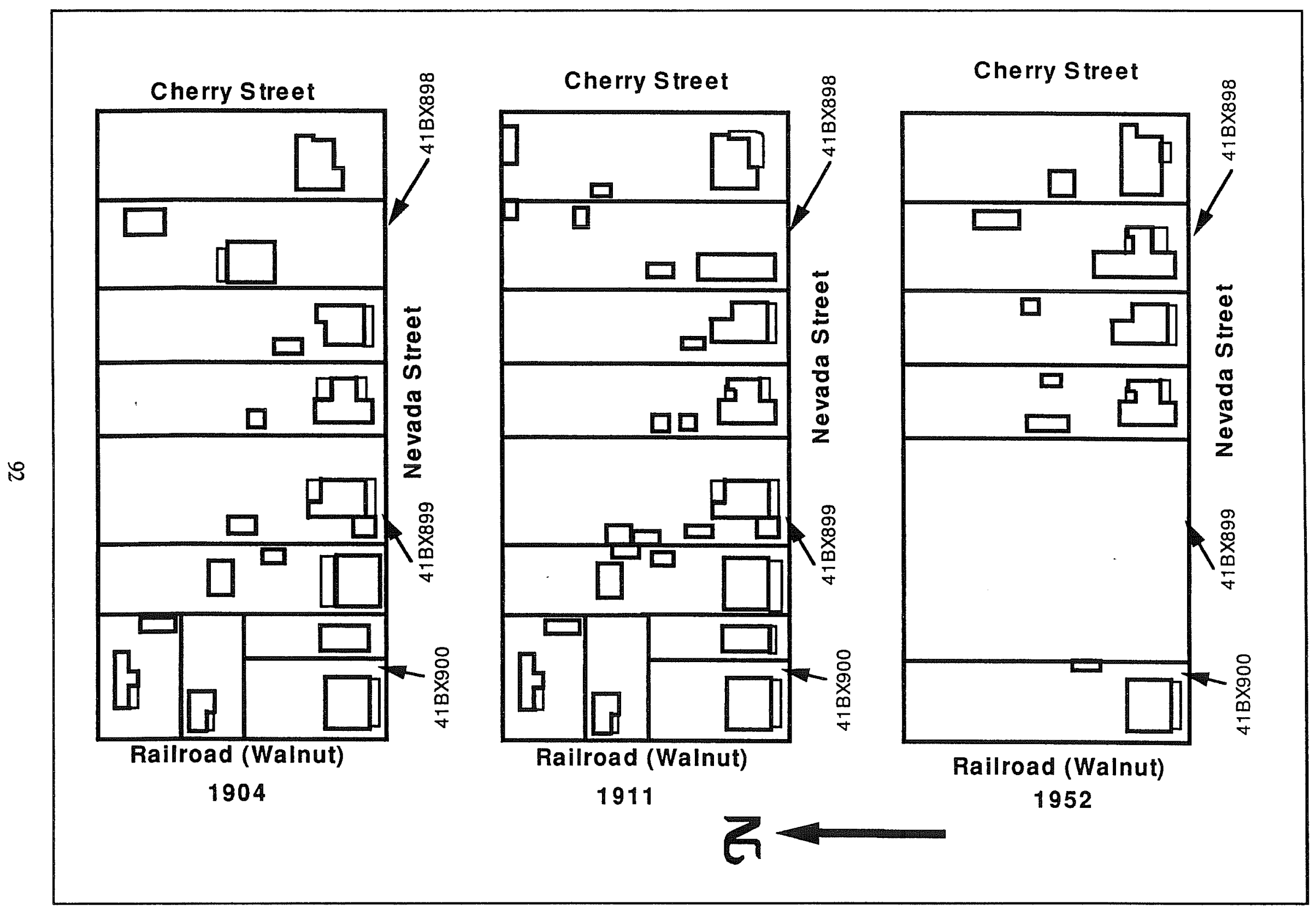

Figure 4-78. NCB 622 (southern half). Adapted from Sanborn maps. 


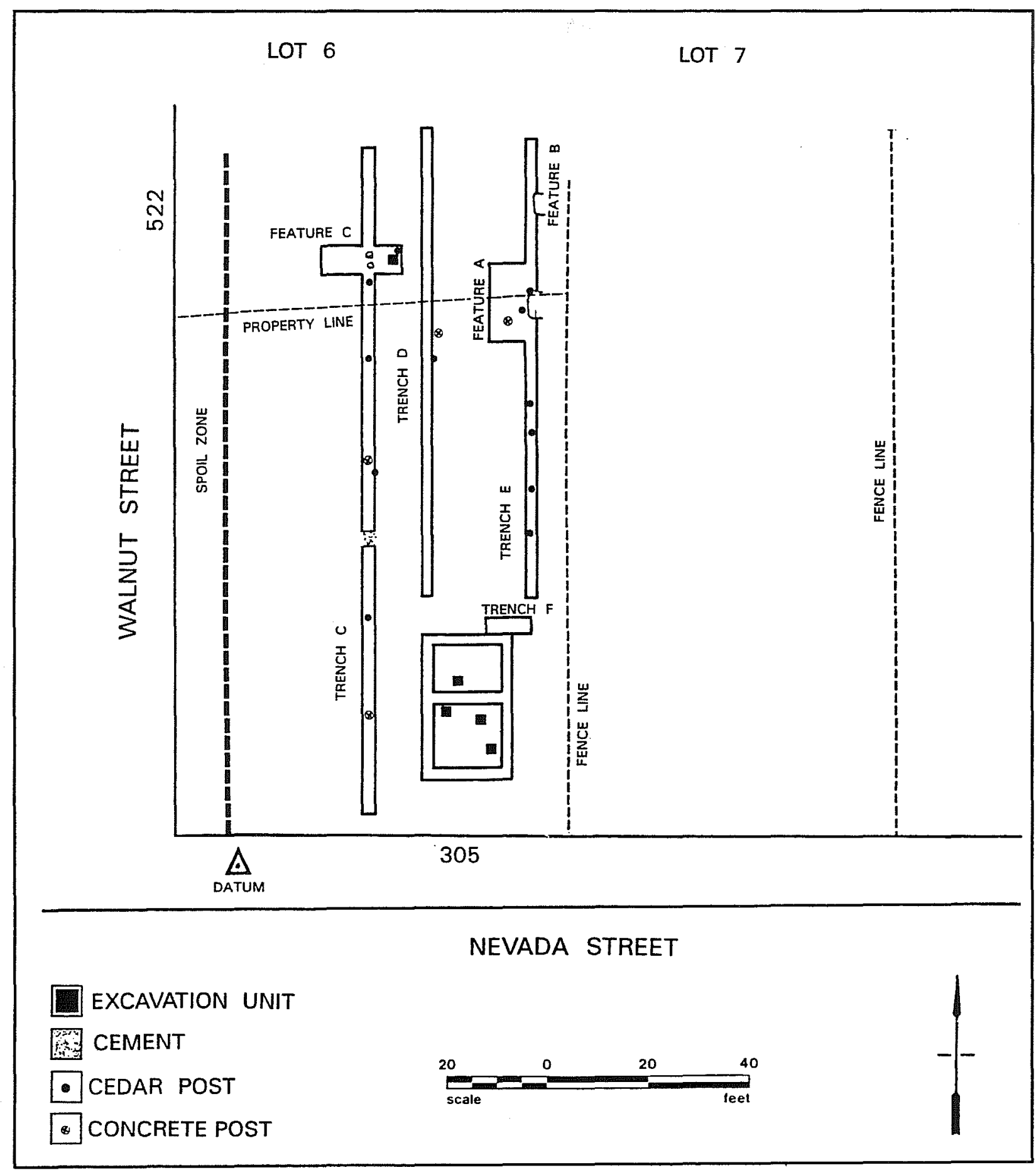

Figure 4-79. 41BX900, site map. 


\section{Phase IV Mitigations}

Between February 27 and March 29, 1991, excavations were carried out on 41BX900. Archival as well as Phase $I I$ testing had indicated the presence of at least part of an intact foundation beneath the surface of the asphalt which had been laid over the entire lot. We did not expect to encounter substantial living surfaces, as it appeared that clearance for the asphalt paving had probably removed or disturbed any living surface. However significant subsurface features (e.g., privies, wells) were expected to have survived virtually intact.

The first major obstacle to be addressed in working this site was the large concrete slab covering about half the area where the adobe dwelling was located. Through cooperation with the local demolition contractors, a large Caterpillar loader (966C) was dispatched to help. It hooked the lower part of the concrete pad and lifted it to a point high enough that it broke off into a small enough piece to move out of the way. In this fashion we were able to clear the area over the adobe foundation with little or no damage to any possible structural elements below.

Once this was accomplished, the smaller backhoe was able to locate and clear off the foundation of the adobe dwelling (Figure 477). A site datum (elevation $653.96 \mathrm{ft}$ amsl) had been established near the southwest corner of Lot 6. This datum point was approximately $240 \mathrm{ft}$ SSE of Monument Number 2, one of the primary datums used during the project (elevation $654.56 \mathrm{ft}$ amsl).

The actual composition of the small structure's foundation was not adobe, but hard limestone blocks. The first stones were encountered 4-12 inches below the asphalt surface. The depth of the caliche fill level varied from 6-8 inches. Preservation of the remaining foundation elements was fairly good.

The foundation appeared to be that of a small, tworoom, settlement saltbox dwelling very similar in form to the one encountered at 41BX897 (they may have been built by the same individual, Jonathan Hildebrant, who was active in the area during the late 1850 s to late 1860s). Overall outside measurements were $29 \mathrm{ft} 8$ inches north/south, by $18 \mathrm{ft} 3$ inches east/west. Wall thickness averaged between 1.5 and $2 \mathrm{ft}$. The larger of the two rooms, measuring $15 \times 15 \mathrm{ft}$, was in the front of the dwelling facing Nevada Street. The smaller rear room measured $8 \times 15 \mathrm{ft}$. No fireplace hearth was evident and no doorways were visible along any part of the foundation at this depth. The largest, most solid visible stones were those composing the north wall of the structure. Testing done along the north wall indicated that only 28 inches of foundation remained above a sterile black clay matrix.

Although it appeared unlikely that intact living surfaces would be present, four $2-\mathrm{x}-2-\mathrm{ft}$ test pits were placed inside the foundation perimeter to test for deposits. Three of the units were placed in the larger front room and one in the rear. Little artifactual material was recovered from these units, primarily cut and wire nails, bottle glass, chicken bone, and metal fragments. Stratigraphically it appeared that the caliche fill layer beneath the parking lot asphalt had partially filled the interior of the foundation. Under the caliche fill was a light brown mixed clay containing most of the artifacts recovered from this location. In one of the units, N36E35, a light-colored marl layer was present. The marl may have represented a floor surface; however, it was more likely spalled and melted plaster from the interior wall surface. The fact that this layer tapered out approximately midway through the unit $(1.8 \mathrm{ft}$ inside the interior west wall) supports this conclusion. No other occurrences of this type of deposit were encountered in any of the other units. Several interesting surface finds were made in the vicinity of N33E42 before the units were started. Earlier in this section reference was made to the discovery of a token during Phase II testing on this site. Two other tokens were also found inside the foundation: one bearing the name "Two Brothers Saloon" and the other heavily corroded but with the word "number" visible on it.

To obtain a balanced sample from the site, we decided to place three backhoe trenches $(C, D$, and $E$ ) running north/south across the southern half of Lot 6 . Trench $C$ would be placed just west of the limestone foundation in an area associated with the west boundary line of the yard for 305 Nevada. Trench D would run from just north of the northwest corner of the limestone foundation across the back yard property line. Trench $E$ would be placed five feet inside the east property line, running north/south from the north foundation wall and crossing the back property line. 
Trench C

Trench $\mathrm{C}$, measuring approximately $130 \mathrm{ft}$ north/ south, was located $9 \mathrm{ft} 5$ inches west of the west wall of the limestone foundation. According to the Sanborn maps, the western property line for 305 Nevada was almost exactly along the line of the west wall of the structure. Therefore this trench would be just outside the west yard of 305 and just inside the east yard of 301. It would run the full length of the yard and enter the south part of the yard formerly occupied by 522 Walnut Street (at $100 \mathrm{ft}$ north).

Trench $C$ exhibited a very complex soil profile. The upper zone (0-14 inches) was composed of the asphalt parking surface from 0-2 inches and a white caliche fill material from 2-14 inches. Directly under the base material was a zone, varying from 9-15 inches wide, of different small lenses with much cultural material. The average depth of the backhoe trench was 33 inches. As many as eight different strata were visible at any given point; however, as previously mentioned, the primary artifact-bearing zone was from 9-15 inches below ground surface. This zone was very uniform for the first $53 \mathrm{ft}$ of the trench. Within the first $53 \mathrm{ft}$, several post holes were encountered that could be associated with the frame structure that once occupied this area (301 Nevada). A half-inch water line was excavated running east/west at $39 \mathrm{ft} 9$ inches, directly past one of these post holes and in a zone just to the north of the limestone foundation.

At $53 \mathrm{ft}$ north, a large concrete pier measuring approximately $3 \times 3 \mathrm{ft}$ and reinforced with heavy rebar was encountered. This pier was probably a support for former tracks of the Southern Pacific Railroad. The pier was impenetrable, so was left in place and the trench was continued on its north side to $56 \mathrm{ft}$. At this point the strata became more variable, composed of lenses of different colored clays and levels of coal running from 2-10 inches thick. Because of the close proximity to the rail line, it is likely these coal deposits resulted from the emptying of loose coal from the bottoms of rail cars (C. K. Chandler, personal communication 1991).

Between 56 and $100 \mathrm{ft}$ north, several other posts and postholes were encountered. Some posts were metal and could be associated with covered parking spaces from Southwestern Bell. Others could have been the remains of practice climbing poles used by South- western Bell (Burnley Smith, personal communication 1991).

After we crossed the north yard boundary line at $100 \mathrm{ft}$, we discovered a series of limestone blocks and post remnants at $110 \mathrm{ft}$ north. Small extensions were opened to the east and west of the trench to further explore the nature of these deposits, and one 2-x-2-ft test unit was placed just to the east of Trench $C$ (Feature C). Based upon these tests and associations found in Trench $\mathrm{D}$ at this point, we felt this feature probably represented the remnants of a shotgun-style dwelling pictured in the 1911 Sanborn map and listed as 524 Walnut Street (Figure 4-78).

Trench D

Trench $\mathrm{D}$ was started at a point 90 inches north of the northwest corner of the limestone dwelling (305). This point was projected to be just inside the west property line of 305 Nevada. The profile of this trench was much more uniform than that of Trench $\mathrm{C}$. The asphalt and caliche fill overlaid a greenish/yellow clay. Below this was a layer of ash and carbon running from 0-10 ft north at a depth of 19 inches below ground surface. The primary matrix throughout the entire trench from 20 inches down was a sterile Austin Black clay. A low to medium artifact zone was present from $30-40 \mathrm{ft}$ north, just under the caliche fill zone about 16 inches below ground surface. At 40-50 ft north and a depth of 15 inches, the coal which was present in Trench $\mathrm{C}$ was encountered.

A cedar post was encountered in the east profile running from 18-34 inches below surface at $46.8 \mathrm{ft}$. This was in a direct line east/west with a post found in Trench $\mathrm{C}$ at this point. From this point to the north boundary of the yard ( $60 \mathrm{ft}$ north) was a very disturbed zone of bricks and rubble, as well as a lens of the coal. This disturbed zone terminates suddenly at $63 \mathrm{ft}$ north. Between 61 and $62 \mathrm{ft}$ north, the west profile exhibited a post mold. Based on this stratigraphic evidence, an outbuilding stood in this location at some time. It would have been about $15 \times 15 \mathrm{ft}$ in size. None of the Sanborn maps indicates a structure present in this location; however the disturbed zone of rubble was very similar to what was encountered on 41BX896 when excavation was done in the vicinity of what the 1904 Sanborn map pictured as a small outbuilding compound. 
Once the trench crossed the north yard boundary and entered the yard associated with 524 Walnut, evidence of the structure pictured on the 1911 Sanborn map was found. Between $64 \mathrm{ft} 2$ inches and $64 \mathrm{ft} 8$ inches north, a line of bricks crossed the trench east/west. This brick alignment was in direct line with the stones and post remnants located in Trench $\mathrm{C}$ just to the west.

\section{Trench E}

This trench ran north/south and started just off the northwest corner of the limestone structure (305 Nevada). The trench was designed to examine possible activity areas along the east boundary line of Lot 6 (A11). The south end of the trench was 90 inches north of the northwest corner of the limestone structure and $18 \mathrm{ft} 8$ inches east of Trench $\mathrm{D}$. The excavation plan called for a trench $90 \mathrm{ft}$ long that would cross the north boundary line of Lot A11 and terminate approximately midway into Lot A10.

As with previously described trenches, an asphalt surface and caliche fill zone 14 inches thick covered the area of the trench. The primary artifact-bearing zone was located from just below the caliche fill to approximately 33 inches below ground surface.

From 0-50 ft north in the trench, five cedar posts were encountered. Three of the posts were large (eight inches in diameter) and probably represent the practice poles used by Southwestern Bell Telephone. Two of the posts were smaller (three inches in diameter). One of these smaller posts was found in an area of high artifact density (36-37 ft north) and may represent an outbuilding along the east side of the lot.

From 50-90 ft north, several important features were encountered. The back boundary line for Lot A11 was located at $60 \mathrm{ft}$ north in the trench. At $56 \mathrm{ft}$ north, an area of limestone rubble fill was present. This was mixed with a brownish matrix that differed significantly from the black matrix encountered in the trench up to this point. At 20 inches depth, large numbers of ceramics were recovered. Once the area was cleared, the remnants of an earthen-vault privy (Feature A) were encountered. We opened an eightfoot section to the west of Trench $E$ to allow further exposure of the plan and profile of the privy vault.
During the initial exposure of Feature $A$, the remnants of three posts were exposed. One was a concrete and metal post associated with covered parking. The second was a cedar post, 10 inches in diameter, which was probably a Southwestern Bell Telephone practice pole. The third was a six-inch diameter cedar post, badly decomposed, located just off the southwest corner of the earthen vault. The top of this post was 31 inches below ground surface. This post was probably part of the privy superstructure. The privy vault appeared to have been capped with a mixture of dark coal-like soil and limestone chunks. The deposits changed to a more ashy-colored soil mixture with charcoal inclusions at a depth of 32 inches. The privy vault outline was better defined at this depth as well.

Another feature (B) was found in the east profile of

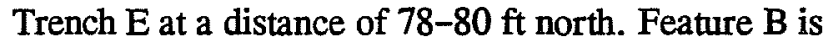
an area of rusty metal mixed with caliche and charcoal, measuring approximately $2 \times 4.5 \mathrm{ft}$ and 20 inches thick. This was probably a trash deposit associated with the occupations at 522 and 524 Walnut Street. Since the feature faded out at the bottom of the trench, we felt it unlikely that this was another privy deposit. This was further supported by the lack of any evidence of surrounding superstructure.

\section{Trench $\mathrm{F}$}

The final trench excavated on this site was placed just north of the limestone structure in an east/west orientation. It was $10 \mathrm{ft}$ long and was designed to test the depth of the limestone foundation to see how much was extant. The foundation extended 15 inches below the ground surface (the elevation at the start of this trench was $650.8 \mathrm{ft}$ amsl). The lowest course of limestone rested on a rubble zone which extended 11 inches below the lowest level of cut stone. Trench F was excavated to a maximum depth of 51 inches. The only other notable feature within the trench was in the central part of the north profile. A vertical intrusion, with very distinct edges and filled with small pebbles, glass, and small metal fragments, was present. The intrusion was too deep and narrow to be a post mold; however, a well-monitoring pit or waterpipe hole could account for this intrusion. 


\section{Artifact Group Distributions and Comments}

As previously mentioned, this site was located beneath an asphalt parking surface, and the original ground surface was disturbed during the placement of this surface. Artifact deposits were found in non-feature context (sheet refuse); however, the sheet refuse deposits had probably been disturbed by the high level of activity carried out across this zone. The site's proximity to the rail line undoubtably had an impact on it, as did its ownership by Southwestern Bell Telephone Company. These factors combined to create a very heavily stratified site, with the existing strata exhibiting a very mixed context. Table 4-14 shows the artifact group percentages for the site.

\section{The Runge Street Excavations}

The southern portion of NCB 636 was one of the few sections of the Alamodome Project that developed a centralized, virtually single ethnic character over the course of time. The basic ethnic element over the entire project area around 1850-1880 was German. After the arrival of the railroad, the area became more ethnically diverse and NCB 636 was no different than the rest of the project area. However, the southern part of NCB 636 did not really start to develop until around 1920. What had been Lots 10 through 15 and Lot 17 of NCB 636 were subdivided in 1917 by Gus Mauermann into 19 smaller units (A-S) and the street named Runge was established (Figure 4-80). The street name comes from Carl Runge who was one of the sole residents of the southern portion of NCB 636, having had a dwelling on Lot 16 since before 1879 (BCDR 24:298, 157:621, CD 1879-1880).

In 1921 Mauermann constructed seven houses in the area (Lots C, D, E, F, G, O, and Q) (BCDR 601:431, CD 1921-1922). An additional five houses (Lots A, B, $\mathrm{J}, \mathrm{N}$, and $\mathrm{P}$ ) were built in 1924, one house (Lot $\mathrm{L}$ ) in 1926, and three houses (Lots H/I, K, and M) in 1929 (CDS 1924-1925, 1925-1926, 1929). All these houses were of pier-and-beam construction and most were constructed as rental properties. After 1948 many of the properties started to be acquired by their residents (Figure 4-81).

The primary ethnicity of the area around Runge Street was African-American. Runge Street sits on the far northeast corner of what was once known as the "Baptist Settlement." Oral historians who lived in the area reported (for the period 1920-1950) that the area was 80-85 percent African-American and 15-20 percent Hispanic, with only a trace of other ethnic groups represented (E. L. Fly and Associates 1990). As one moved northward through the Alamodome development area, the ethnicity became more varied with Germans, Poles, Hispanics, and AfricanAmericans represented in a more balanced distribution. Around 1941 a large portion of the Baptist Settlement was demolished in the development of Victoria Courts, one of San Antonio's earliest public housing projects.

Table 4-14. Site Artifact Frequency Distributions for 41BX900

\begin{tabular}{|c|c|c|c|}
\hline Group & $\#$ & $\%$ & Notes \\
\hline Activity & 244 & 5.02 & 87 misc. metal; 62 wire frags. \\
\hline Architecture & 2,253 & 46.35 & 1,158 wire nails; 547 cut nails \\
\hline Arms & 10 & 0.21 & 7 cartridges; 3 shotgun shell casings \\
\hline Bone & 441 & 9.07 & \\
\hline Clothing & 65 & 1.34 & 44 buttons; 11 buckles \\
\hline Furniture & 19 & 0.39 & 6 lamp parts \\
\hline Kitchen & 1,796 & 36.95 & 999 bottle glass; 752 ceramics \\
\hline Personal & 33 & 0.68 & 13 slate frags. \\
\hline Total: & 4,861 & 100 & \\
\hline
\end{tabular}




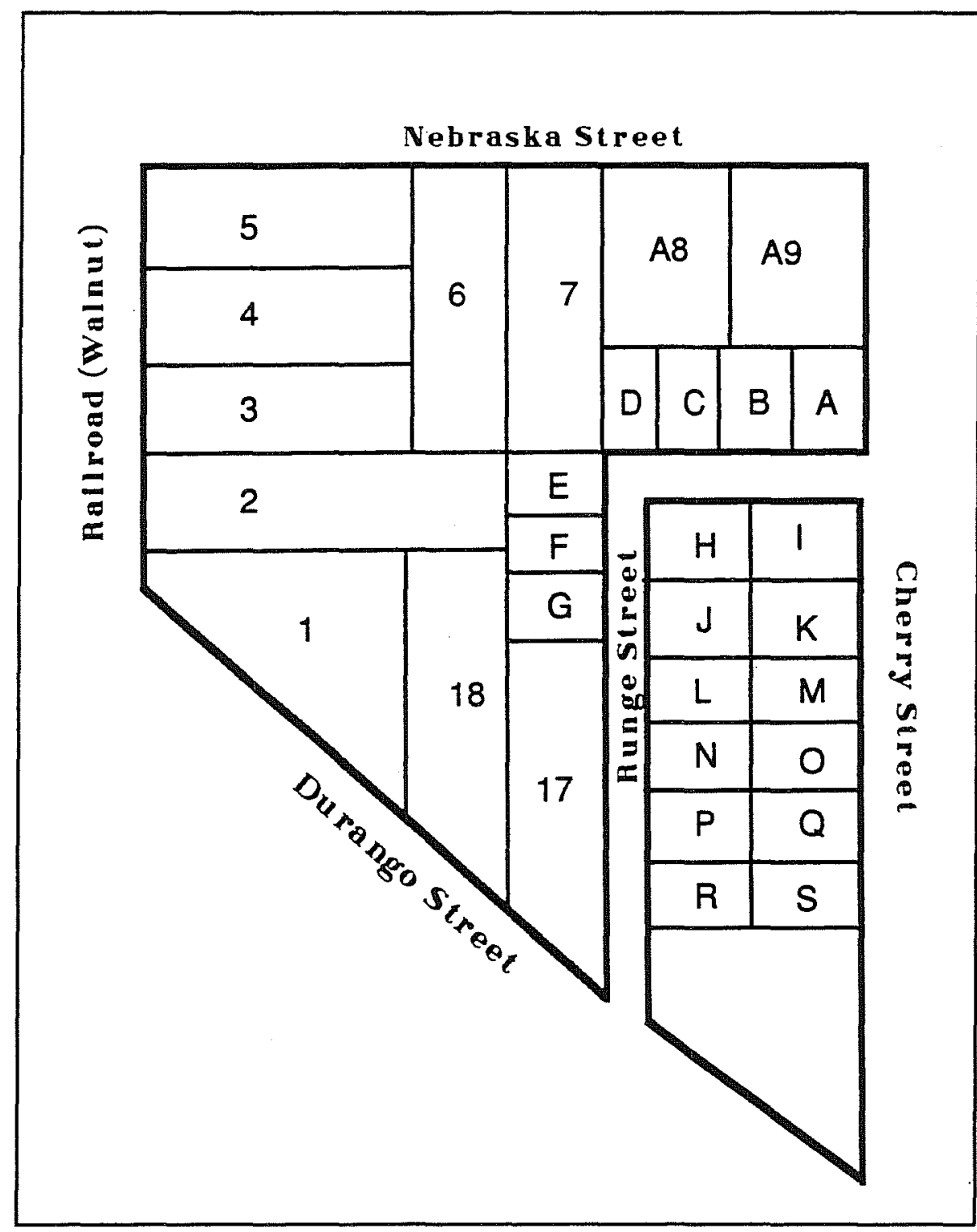

Figure 480. NCB 636, resubdivision of lots 10-15, filed December 20, 1918.

We decided that although the area around Runge Street developed at a time later than most of the areas under investigation within the Alamodome Project, the close association of so many residences to a single ethnic background presented an opportunity to gather significant data regarding African-American settlement and lifeways during this period (1920-present). Since much of the Baptist Settlement had been destroyed during the construction of Victoria Courts and since Runge Street would be destroyed by the Alamodome development, this might be the last chance to investigate this kind of settlement in San Antonio.
Although many of the individual lots within the Runge Street area received separate site designations, a slightly different strategy was used in the excavation of this area. The placement of excavation units and backhoe trenches would focus to some extent on the whole area of South NCB 636 as a single occupation site, rather than separate units and trenches being placed on each individual lot. Approximately $215 \mathrm{ft}$ of the extreme south end of NCB 636 had been demolished in the construction of an overpass for Durango Street over the railroad tracks in 1968. Unfortunately the area occupied by Mr. Runge in the late 1800 s was part of what was destroyed. Also destroyed were the greater parts of Lots $P, Q, R$, and $S$. The city public works department had also established a lay down yard just to the west of Runge Street extending to the railroad tracks. This lay down yard had eliminated Lots E, F, and G.

When investigations began, only seven of the original 19 lots (Lots A, B, C, K, M, N, and $O)$ still had standing residences. Several of the dwellings appeared to have been moved out fairly recently (Lots $H / I$ and D), while others appeared to have been vacant for a longer period (Lots J and L). When excavation started, many of the houses in this area-although abandoned by their official residents and condemned for demolition-were still being occupied by transients, prostitutes, and drug dealers/users. 


\section{Excavations (Figure 4-82)}

Before excavations began, the whole area was surface collected in a controlled fashion. Additionally, all extant homes were photographed and plan drawings made of their interior space. Surface examination indicated that just north of Runge Street, a small alley that ran east from Cherry Street had at one time extended into NCB 636. This alley ran behind Lots A-D and terminated at two small houses set back from the street in the rear of Lots 6 and 7 (1191/2 Martin Luther King and 1321/2 Runge). The structure on Lot D had been removed; however, surface finds indicated the presence of artifacts possibly predating the development of the Runge Street houses.

We decided to concentrate excavations in two areas, designated 1 and 2 . Area 1 (nicknamed "The Island") was formed by Runge

Street, Cherry Street, and a fenceline bordering Durango Street. This included Lots H, I, J, K, L, M, $\mathrm{N}, \mathrm{O}$, and the remnants of Lots $\mathrm{P}$ and $\mathrm{Q}$. Area 2 encompassed the area surrounding Lots $C$ and $D$, as well as the central sections of Lots A8 and 7.

Area 1 represented the far southeast corner of the Alamodome Project area. It was nicknamed the island because the distinctive L-shape of Runge Street isolated the houses from the rest of the NCB to the north.

When excavations started, four houses were present on the island (on Lots $\mathbf{K}, \mathbf{M}, \mathrm{O}$, and $\mathrm{N}$ ). Two small outbuildings were also present, one on Lot $\mathrm{H}$ and the other on Lot $\mathrm{O}$. Lot $\mathrm{N}$ had an overlapping carport, attached to the house, with a small storage shed inside.

\section{Area 1 (The Island)}

Three backhoe trenches were placed to provide maximum coverage for the space excavated. Trench A ran down the south boundary line of Lots $H$ and $I$, which had been developed as a single lot, and represented the largest occupation space on this part of the NCB. Trench D started in the northeast corner of Lot $J$ and ran south to the fenceline which bordered Durango Street (approximately $144 \mathrm{ft}$ ). The trench was 


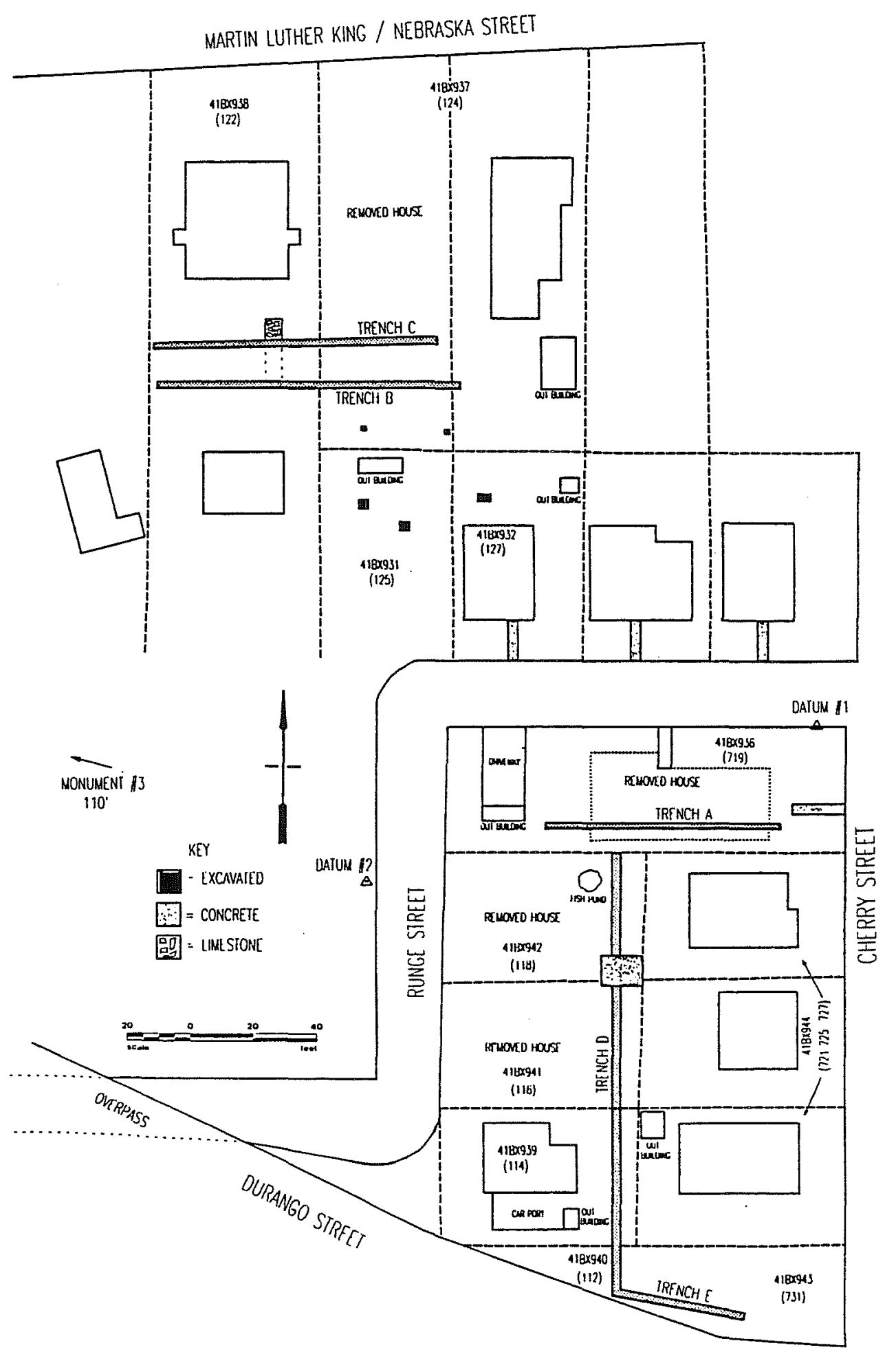

Figure 4-82. Runge Street area excavation map. 
placed to completely cross the east end of Lots J, L, and $\mathrm{N}$, and half of the remnants of Lot $\mathrm{P}$. Trench $\mathrm{E}$ started at the south end of Trench D and ran eastward toward Cherry Street. This placed the majority of the trench in what remained of Lot Q.

\section{Trench A}

By the time Trench A was excavated, the house that had been present on Lots $\mathrm{H}$ and $\mathrm{I}$ had been removed. A sidewalk running from Cherry Street to the west indicated where one entrance to the house had been. Another sidewalk running from Runge Street to the south indicated where another entrance had been. A cement driveway was present on the west side of Lot $\mathbf{H}$, at the south end of which was a small outbuilding that appeared to have been used for storage.

A site datum (elevation $652.11 \mathrm{ft}$ amsl) was established just west of the northeast corner of Lot I near Cherry Street. Lots $\mathrm{H}$ and I were designated 41BX936, the Burleson site. This was one of the few residences in this area which was owned from the start rather than serving as rental property. Homer Burleson, the original owner, lived in the home from 1921-1946.

A series of cedar posts ran east/west along where the south side of the house would have stood. Several other posts were present around the outside margin of the lot indicating that at some time the lots had been surrounded by a fence. chicken wire and green plaster, running around the bottom of the structure. The apron extended from the floor of the house at the top of the piers to the ground. Some of the apron was still present in the soil, allowing us to trace the exterior shape of the structure.

From 0-46 ft west, the remains of eight cedar post supports for the residential structure were found. The posts were set in concrete anchors measuring 14-15 inches in diameter. The stratigraphy was fairly uniform, being composed of varying layers of brown clay and tan caliche fill material.

Between 62 and $72 \mathrm{ft}$ west, the stratigraphy became much more complex. The remains of four small cedar posts were revealed at $62.5 \mathrm{ft}$, one at $65.5 \mathrm{ft}$, and two at $66 \mathrm{ft}$ west. A distinct stratigraphic break took place at $65.5 \mathrm{ft}$ west about six inches below ground surface. The soil changed from a reddish sandy caliche to a dark sandy charcoal mixed with the very soft remains of bricks. The bricks were so poorly preserved that they were no longer solid, however their contrast with the surrounding matrix still showed their distinctive shapes very well. Also at 65.5 west, dividing these two areas of soil, was a vertical fragment of wood, apparently the bottom portion of a wall. These were the remains of a previous structure placed in this location and running further west under where the current driveway and storage building stood. The large

Trench A was placed in an east/west orientation, running just north of the posts marking the south side of the residence. The east end of the trench was located just off the southwest corner of the sidewalk that approached the house from Cherry Street. The west end of the trench was just short of the small outbuilding on Lot $\mathrm{H}$. The final dimensions of Trench A were $2 \times 72 \times 2 \mathrm{ft}$.

The residence that had been present on these two lots showed evidence of having had an apron, composed of

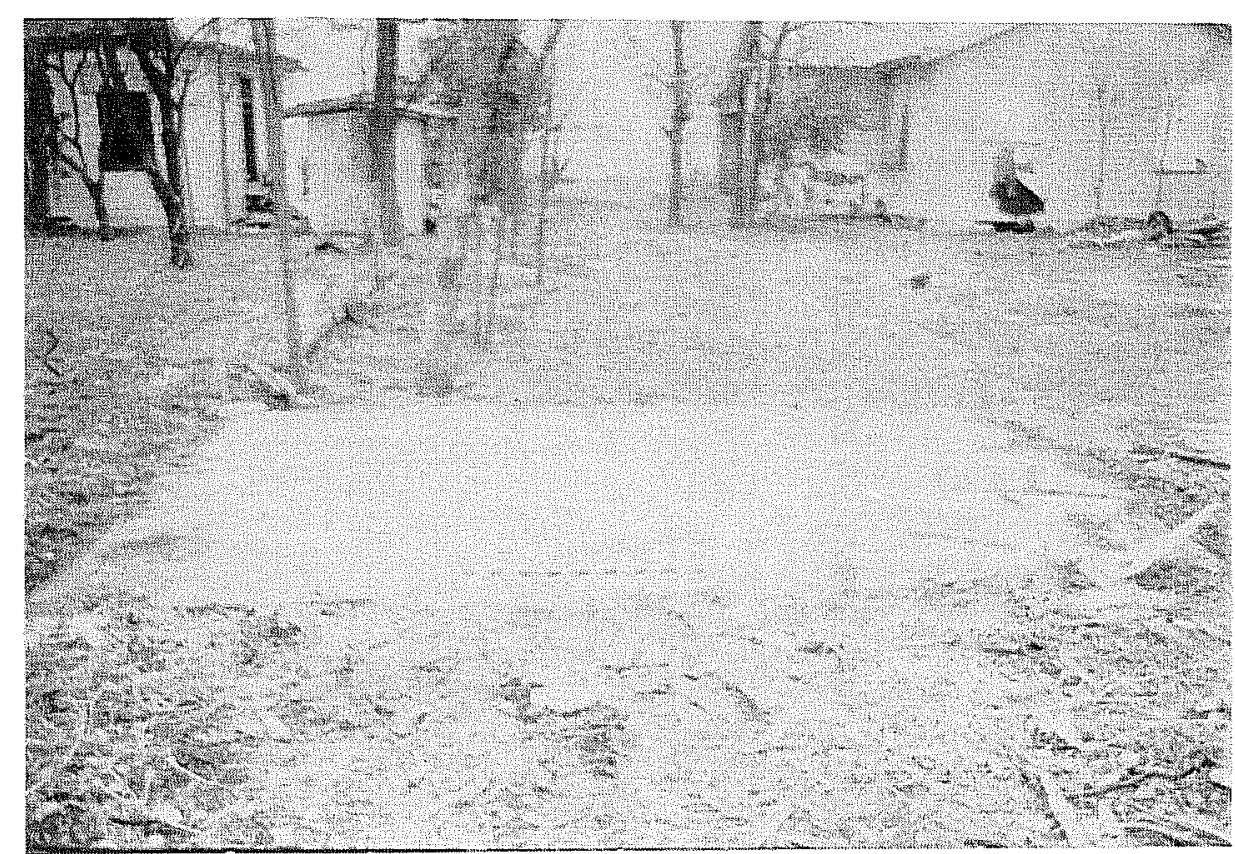

Figure 4-83. Excavation area for Trench $D$. 
amount of charcoal present suggested that the structure may have burned.

\section{Trench D (Figure 4-83)}

Trench D measured $2 \times 144 \times 2 \mathrm{ft}$. Four sites were established in the course of excavating this trench: 41BX939, 41BX940, 41BX941, and 41BX942. Three of the four lots examined no longer held any residences, only Lot N (41BX939) still had a residence present. Lot J (41BX942) contained a large cement slab in its southwest corner and what appeared to be an above-ground cement fish pond was present toward the northwest corner. No direct evidence was found to indicate that structures had been located on any of these lots, except Lot L (41BX941) where the remains of concrete porch steps were still present. Several cedar posts and the decomposed remains of a wooden fence were present across the back of the lots.

Within the trench, artifact density was fairly high and continued to a depth of approximately 12 inches below ground surface. The stratigraphy showed that over time, alternate layers of fill material had been placed over the lots, especially in the southern ones (P and $\mathrm{N}$ ). The stratigraphy was disrupted in several locations where iron and ceramic sewer lines were encountered running east/west across the trench. The lines appeared to be contemporary. It is likely that the construction of the overpass which destroyed the southern end of NCB 636 also significantly impacted these lots. Some of the fill material can be attributed to this construction.

At $112-113 \mathrm{ft}$ north on Lot J, evidence indicative of intentional burying of refuse was encountered. At 20 inches below ground surface, a tin-enameled metal chamberpot, filled with bottle glass and metal fragments, was found. A 2-x-2-ft test unit was established off the east profile of the trench to examine this deposit (Feature F). In the course of excavation, a second tin-enameled metal chamberpot was revealed. This pot contained ceramics, glass, medicine bottles, and metal fragments. Maker's marks on the ceramics suggest a date of about 1926 (Tennis, Volume III).

Trench E (Figure 4-84).

This trench measured $2 \times 40 \times 2 \mathrm{ft}$. It was placed with an east/west orientation running east from the south end of Trench D. Starting in Lot $P$, the trench crossed over into Lot Q (41BX943). This trench was placed to search for possible remnants of the Valley Ditch, which archival sources indicated should be in the area (Waynne Cox, personal communication 1991). The Valley Ditch was not found in this trench; we later determined the ditch ran north/south down the west side of Cherry Street. If this trench had been carried another $30 \mathrm{ft}$ to the east, the ditch would likely have been revealed (Gross and Mendez, Volume III).

Three cedar post supports associated with the structure located on this lot before the addition of the Durango Street overpass were found at 13,21 , and $27 \mathrm{ft}$ east in the trench. This lined up well with the placement of the still-existing homes just to the north on the other lots.

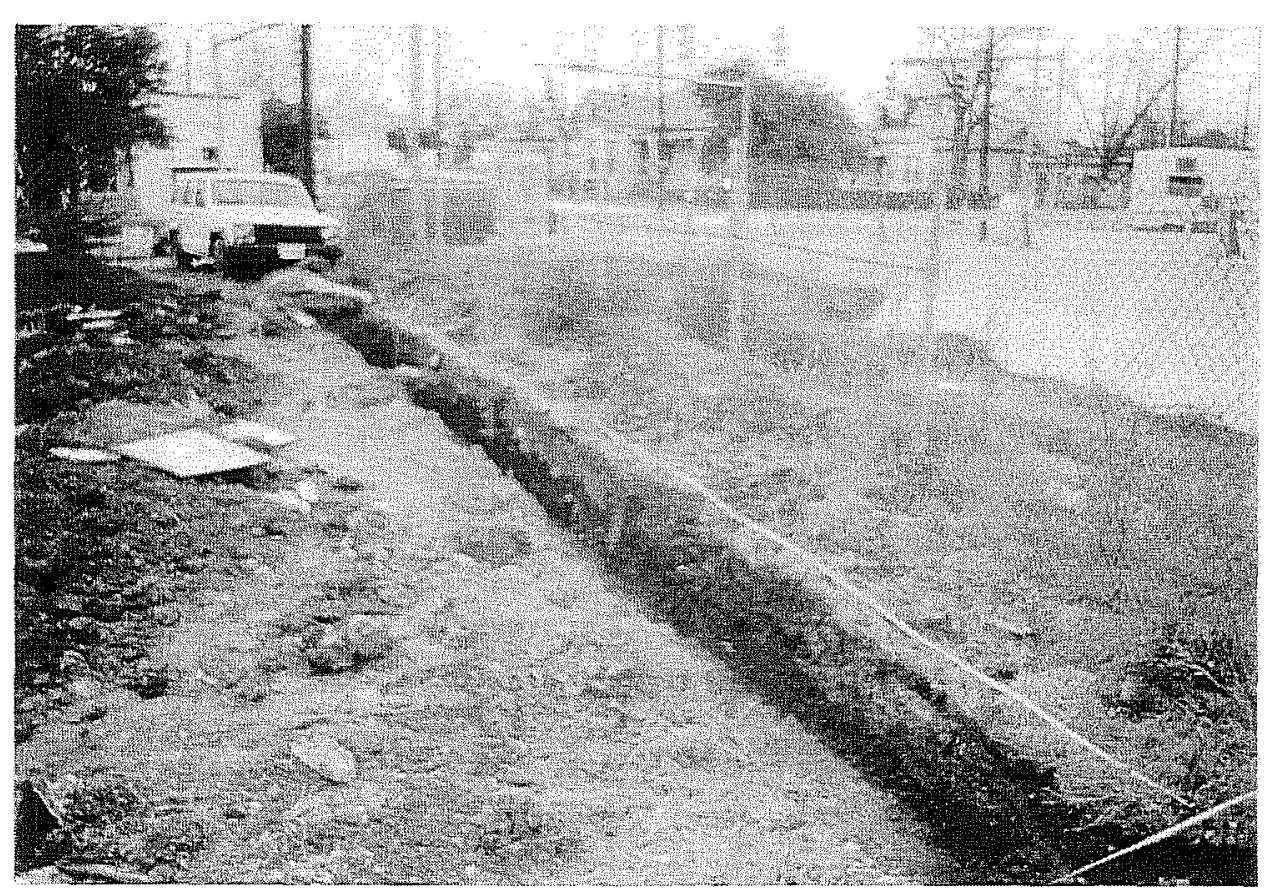

Figure 4-84. Trench E (Durango Street in background). 


\section{Area 2 Excavations}

Area 2 was located to the northwest of Area 1, and contained NCB 636 Lots C, D, 7, and A8. The area had houses fronting on both Martin Luther King and Runge streets. One residence was also located in the center of $\operatorname{Lot} 7$, away from the streets.

When investigations started, the house located on Lot D had been removed, but a small outbuilding was still present on the north end of this lot (acting as a shelter for a homeless person). Shortly after work began, the home on Lot A8 (west) was removed. Lot 7 contained a small duplex apartment complex and the whole site surface was covered with asphalt. Due to visibility problems from Datum 1 to this area, Datum 2 was established on the west side of Runge Street across from Lot J (elevation $651.23 \mathrm{ft}$ amsl).

Two backhoe trenches ( $B$ and $C$ ), two 4-x-4-ft units, and four 2-x-2-ft units were placed in this area. The backhoe trenches were initially designed to investigate the area which in the 1904 Sanborn map showed a structure referred to as an "ironclad." Since this was the only structure of this designation on the maps we were using, we decided to see if remnants of this unique structure might be found.

Surface examination of the area around Lots C and D had revealed several ceramic sherds which indicated a deposition time earlier (1880-1890) than the development of the Runge Street area (1920s). Since the houses fronting on Martin Luther King Street had been built during this earlier period, the area occupied by Runge Street probably contained activity areas associated with these earlier houses on its northern side. Therefore several hand-excavated units were placed in and around this area to test the extent of the surface deposits.

\section{Trench B}

Measuring $2 \times 95 \times 2 \mathrm{ft}$, this trench was placed in an east/west orientation running across Lot A8 (41BX937) and Lot 7 (41BX938). Two major features were revealed in the trench.

1) Between 57 and $59 \mathrm{ft}$ west, the north and south profiles exhibited large limestone slabs, suggestive of some kind of surface crossing the trench at this point.

2) Two cedar posts were found, one at $79.2 \mathrm{ft}$ west, the other at $86 \mathrm{ft}$ west. From about $80 \mathrm{ft}$ west to the end of the trench ( $94 \mathrm{ft}$ west), a high density of artifacts was encountered, especially metal fragments and items (nails, railroad spikes, metal sheeting). We felt this represented the remains of the "ironclad" structure, and that the building was simply a wooden superstructure covered by thin metal sheeting.

Trench C

Trench $\mathrm{C}$ measured $2 \times 89 \times 2 \mathrm{ft}$ and was placed parallel to Trench B about $14 \mathrm{ft}$ to the north. One major feature was found in this trench. Associated with the limestone slabs found in Trench $B$, at $50-53 \mathrm{ft}$ west in Trench $\mathrm{C}$, more slabs were revealed. An extension $36 \times 45$ inches was made off the north side of Trench $C$ in the area of these limestone slabs (designated Feature A). A walkway predating the asphalt surface covering the whole lot was revealed. The limestone surface ran at least 45 inches to the north of Trench $C$ and continued to the south through Trench $B$. It appeared to approach the structure located on the south end of Lot 7 (1231/2 Runge Street) which first appears in the city directories in 1927.

\section{Units}

Archival information indicated that development of Lot A8 of NCB 636 began around 1885 (BCDR 73:508; CD 1885-1886). Several hand-excavated units were placed on this lot and adjacent Lots $C$ and $D$ to determine the extent of a possible midden deposit located in this area. A roughly circular midden composed primarily of bottle glass and ceramic sherds was revealed. Maker's marks on many of the ceramics derived from these units (most at a depth of from 5-10 inches) dated the deposit to the early 1880 s (Tennis, Volume III). Maker's marks from ceramics located in Area 1 indicated a later date (about 1926), so it is doubtful that disposal activity from the houses on Martin Luther King Street (then Nebraska Street) was being carried out as far south as Area 1. 


\section{Artifact Group Distributions and Comments}

Eight of the 11 sites recorded in this area qualified for inclusion in this study (i.e. had >500 artifacts in the collection). One of the primary factors affecting artifact distributions on these sites was their relatively small size. The average size for Runge Street lots was $4,928.75 \mathrm{ft}^{2}$, in contrast to an average size of $11,216.23 \mathrm{ft}^{2}$ for the lots to the north of Runge Street. This small lot size caused activity areas to overlap, mixing their archaeological contexts. The lot size also limited the size and scope of the activity areas. Storage of raw materials was limited by the size of the area available as storage space. Storage areas (firewood piles, loose lumber storage) were observed on the lots; however, the additional space available on the lots to the north of Runge Street permitted a greater flexibility in the amount of space utilized for storage purposes.

Incidents of trash disposal in pits on the Runge lots was also observed; however, there was a limitation to the size of these pits, also due to a shortage of space. The trash pits observed in the Runge area were very small (2-3 $\mathrm{ft}$ in diameter), while trash pits observed on sites with greater overall space tended to be quite large (sometimes as large as $12 \mathrm{ft}$ in diameter). Tables 415-4-22 show the artifact group percentages for the sites studied in this area.

Table 4-15. Site Artifact Frequency Distributions for 41BX931

\begin{tabular}{||r|r|r|l||}
\hline \multicolumn{1}{|c|}{ Group } & \multicolumn{1}{c|}{$\#$} & \multicolumn{1}{c|}{$\%$} & \multicolumn{1}{c|}{ Notes } \\
\hline Activity & 398 & 18.96 & 360 misc. metal \\
\hline Architecture & 608 & 28.97 & 250 wire nails; \\
\hline Arms & 1 & 0.05 & 1 shotgun shell casing \\
\hline Bone & 72 & 3.43 & \\
\hline Clothing & 7 & 0.33 & 5 buttons \\
\hline Furniture & 30 & 1.43 & 26 lamp parts \\
\hline Kitchen & 954 & 45.45 & 645 bottle glass frags. \\
\hline Personal & 29 & 1.38 & 25 slate frags. \\
\hline Total: & $\mathbf{2 , 0 9 9}$ & $\mathbf{1 0 0}$ & \\
\hline
\end{tabular}

Table 4-16. Site Artifact Frequency Distributions for 41BX932

\begin{tabular}{|l|r|r|l|}
\hline Group & \multicolumn{1}{|c|}{\begin{tabular}{c} 
\% \\
\hline Activity
\end{tabular}} & \multicolumn{1}{c|}{ Notes } \\
\hline Architecture & 475 & 2.42 & 22 misc. metal \\
\hline Arms & 0 & 0.00 & \\
\hline Bone & 119 & 11.07 & \\
\hline Clothing & 15 & 1.40 & 10 buttons \\
\hline Furniture & 12 & 1.12 & 11 flower pot frags. \\
\hline Kitchen & 424 & 39.44 & 273 bottle glass; 119 ceramics \\
\hline Personal & 4 & 0.37 & 1 pen/pencil; 1 coin \\
\hline \multicolumn{1}{r|}{ Total: } & $\mathbf{1 , 0 7 5}$ & $\mathbf{1 0 0}$ & \\
\hline
\end{tabular}


Table 4-17. Site Artifact Frequency Distributions for 41BX936

\begin{tabular}{||l|r|r|l||}
\hline \hline Group & \multicolumn{1}{|c|}{$\#$} & \multicolumn{1}{|c||}{ N } & \multicolumn{1}{|c||}{ Notes } \\
\hline Activity & 61 & 6.07 & 27 misc. metal \\
\hline Architecture & 638 & 63.48 & 343 wire nails; 101 window glass \\
\hline Arms & 0 & 0.00 & \\
\hline Bone & 67 & 6.67 & \\
\hline Clothing & 24 & 2.39 & 17 buttons \\
\hline Furniture & 5 & 0.50 & 3 flower pot frags.; 1 furniture part \\
\hline Kitchen & 205 & 20.40 & 163 bottle glass frags. \\
\hline Personal & 5 & 0.50 & 1 slate frag.; 1 coin; 1 hair care item \\
\hline \multicolumn{1}{|r|}{ Total: } & 1,005 & 100 & \\
\hline
\end{tabular}

Table 4-18. Site Artifact Frequency Distributions for 41BX937

\begin{tabular}{||l|r|r|l||}
\hline \multicolumn{1}{|c|}{ Group } & \multicolumn{1}{c|}{$\#$} & \multicolumn{1}{c|}{$\%$} & \multicolumn{1}{c|}{ Notes } \\
\hline Activity & 69 & 4.84 & 32 misc. metal \\
\hline Architecture & 557 & 39.06 & 204 wire nails; 131 tile \\
\hline Arms & 0 & 0.00 & \\
\hline Bone & 73 & 5.12 & \\
\hline Clothing & 21 & 1.47 & 8 buttons; 7 hooks/snaps \\
\hline Furniture & 11 & 0.77 & 7 flower pot frags. \\
\hline Kitchen & 690 & 48.39 & 590 bottle glass frags \\
\hline Personal & 5 & 0.35 & 3 pens/pencils; 2 coins \\
\hline \multicolumn{1}{|r|}{ Total: } & 1,426 & 100 & \\
\hline
\end{tabular}

Table 4-19. Site Artifact Frequency Distributions for 41BX938

\begin{tabular}{|c|c|c|c|}
\hline Group & \# & $\%$ & Notes \\
\hline Activity & 156 & 6.70 & 43 misc. metal; 41 plastic items \\
\hline Architecture & 884 & 37.97 & 688 wire nails \\
\hline Arms & 2 & 0.09 & 1 cartridge; 1 shotgun shell casing \\
\hline Bone & 117 & 5.03 & \\
\hline Clothing & 19 & 0.82 & 10 buttons \\
\hline Furniture & 12 & 0.52 & 6 flower port frags; 6 furniture parts \\
\hline Kitchen & 1,125 & 48.32 & 749 bottle glass frags.; 310 ceramics \\
\hline Personal & 13 & 0.56 & \\
\hline Total: & 2,328 & 100 & \\
\hline
\end{tabular}


Table 4-20. Site Artifact Frequency Distributions for 41BX939

\begin{tabular}{|l|r|r|l||}
\hline \multicolumn{1}{|c|}{ Group } & \multicolumn{1}{c|}{$\#$} & \multicolumn{1}{c|}{ \% } & \multicolumn{1}{c||}{ Notes } \\
\hline Activity & 82 & 5.38 & 22 unidentified metal; 18 plastic items \\
\hline Architecture & 833 & 54.66 & 603 wire nails \\
\hline Arms & 0 & 0.00 & \\
\hline Bone & 261 & 17.13 & \\
\hline Clothing & 18 & 1.18 & 13 buttons \\
\hline Furniture & 10 & 0.66 & 6 furniture parts \\
\hline Kitchen & 305 & 20.01 & 204 bottle glass \\
\hline Personal & 15 & 0.98 & \\
\hline Total: & 1,524 & 100 & \\
\hline
\end{tabular}

Table 4-21. Site Artifact Frequency Distributions for 41BX941

\begin{tabular}{||r|r|r|l||}
\hline \multicolumn{1}{|c|}{ Group } & \multicolumn{1}{c|}{$\#$} & \multicolumn{1}{c|}{$\%$} & \multicolumn{1}{c|}{ Notes } \\
\hline Activity & 124 & 7.16 & 70 plastic items; 17 misc. metal; 16 machinery parts \\
\hline Architecture & 614 & 35.45 & 299 wire nails; 206 cut nails \\
\hline Arms & 0 & 0.00 & \\
\hline Bone & 81 & 4.68 & \\
\hline Clothing & 7 & 0.40 & 3 buttons; 2 buckles \\
\hline Furniture & 23 & 1.33 & 23 flower pot frags. \\
\hline Kitchen & 869 & 50.17 & 803 bottle glass frags. \\
\hline Personal & 14 & 0.81 & 8 mirror glass \\
\hline \multicolumn{1}{r|}{ Total: } & 1,732 & 100 & \\
\hline
\end{tabular}

Table 4-22. Site Artifact Frequency Distributions for $41 B \times 942$

\begin{tabular}{|l|r|r|l||}
\hline \multicolumn{1}{|c|}{ Group } & \multicolumn{1}{c|}{\begin{tabular}{c}
\multicolumn{1}{c|}{$\%$} \\
\hline Activity
\end{tabular}} & \multicolumn{1}{c|}{ Notes } \\
\hline Architecture & 1,194 & 3.43 & 40 plastic items; 23 wire frags.; 24 misc. metal \\
\hline Arms & 2 & 0.07 & 2 cartridges \\
\hline Bone & 147 & 4.85 & \\
\hline Clothing & 16 & 0.53 & 12 buttons \\
\hline Furniture & 6 & 0.20 & 3 furniture parts \\
\hline Kitchen & 1,539 & 50.73 & 1,366 bottle glass frags. \\
\hline Personal & 26 & 0.86 & 15 mirror glass \\
\hline \multicolumn{1}{r|r|}{ Total: } & $\mathbf{3 , 0 3 4}$ & $\mathbf{1 0 0}$ & \\
\hline
\end{tabular}




\section{BX945 - NCB 615, Lots 15 and 16}

From March 27 to May 22, 1991, excavations were carried out at NCB 615, Lots 15 and 16, 325 Dakota Street, the Pauly House (Figure 4-85). This area was originally purchased by Peter Pauly, a German immigrant who worked as an architect and stonemason in 1855 . Pauly built the large limestone house on the property. This was one of the largest residences in the neighborhood. Pauly continued to live in the house until his death in 1894 at the age of 83 (BCDR 179:604). The property then passed to his three surviving children.

In 1898 the property was sold to William Mueller, a butcher. Mueller was the husband of Martha Czernecki, whose family resided just across Pauly Alley to the north (NCB 615, Lot 7 - 41BX893, BCDR 63:33). In 1921 Mueller's son, William F., constructed a two-story bungalow on the north end of Lot 16 (419 Cherry Street, CD 1920-1921). William Sr. and his wife continued in residence at 325 Dakota until his death in 1951 (CD 1950-1951). Shortly thereafter until its destruction in 1975 , the house was a rental.

The 1904 Sanborn map (Figure 4-38) shows the primary dwelling in the central part of Lot 15 near the east boundary of Lot 16. A large carriage house runs all the way across Lot 15 on the north side. Two small outbuildings (one listed as adobe) rest just to the south of the carriage house near the west boundary of Lot 15 . One small outbuilding is present on the north central boundary line next to Pauly Alley.

By 1911 several changes had been made to the lots (Figure 4-38). The primary dwelling shows modifications to its north side. Two outbuildings rest against the northwest boundary line. The earlier carriage house is gone, but a new one is pictured in the far northwest corner of Lot 15 and a sizable porch surrounds it.
The 1952 Sanborn map (Figure 4-38) shows the primary dwelling identical to its 1911 representation. One small outbuilding is still present in the same location on the northwest boundary line of Lot 15 . The carriage house is still present in the far northwest corner of the lot. On the north end of Lot 16, the bungalow built by William F. Mueller is pictured, as is a small outbuilding to the southwest of it.

When excavations began in 1991, all traces of structures on Lot 15 were gone with the exception of minor surface evidence of the limestone primary dwelling. The 1921 bungalow and its attendant outbuilding were still present on Lot 16 . The outbuilding appeared to have been used as a garage (Figure 4-86).

\section{Excavations (Figure 4-87)}

A site datum (elevation $656.76 \mathrm{ft}$ amsl) was established in the southeast corner of Lot 16 near Dakota Street. A series of shovel tests was set up to cover the northwest corner of Lot 15 , as well as several other locations across both of the lots. Two rows of shovel tests were run across the northwest corner of Lot 15 (ST\#s 1-19). The first row was located $10 \mathrm{ft}$ inside the west boundary of Lot 15 , with tests being spaced $10 \mathrm{ft}$ apart north/south. The second row was placed five feet

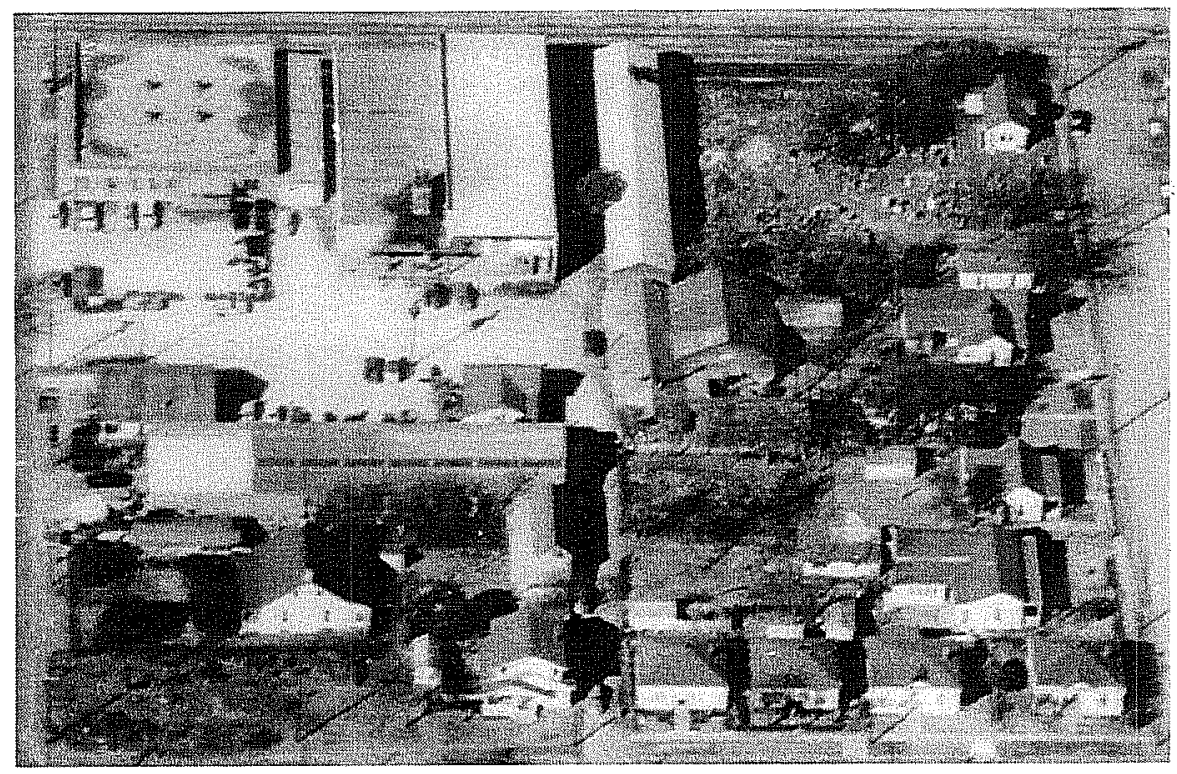

Figure 4-85. NCB 615, ca. 1955. Facing west. 


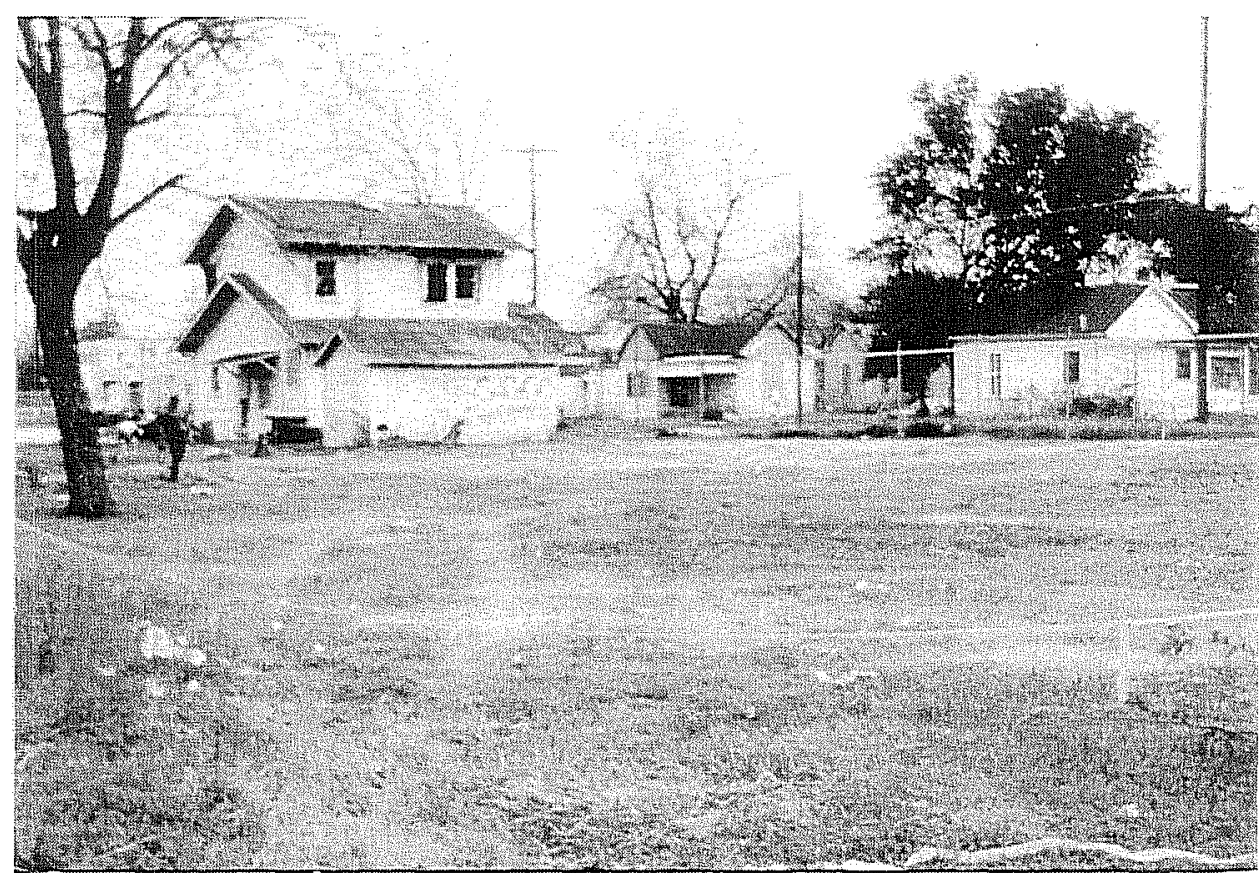

Figure 4-86. View of $41 B \times 945$ before excavation. Facing northeast.

one whose vault was constructed of limestone blocks.

This feature was carefully excavated on both sides to a maximum depth of 80 inches (Figure 4-89). Although constructed of heavier material, the vault still showed evidence of external soil stress, as the sides had the characteristic slumped appearance. The cultural deposit present in the fill continued to a depth of 76 inches. Below 76 inches the soil changed to a sterile, greenish caliche fill which represented the bottom of the deposit. Most of the

further to the east. These tests, 41 in all, were designed to provide information on the outbuildings which were supposedly once located in this corner of Lot 15 , and to gather data relating to sheet refuse deposit across this section of the lot.

\section{Trench A}

This $20-\mathrm{x}-60-\mathrm{ft}$ trench was placed five feet inside the west boundary line of Lot 15, starting about eight feet from the north boundary line of Pauly Alley. The U.S. Heat Treating Company building was located along the west boundary line of Lot 15.

Approximately $42 \mathrm{ft}$ south in Trench A, we encountered the remains of a rectangular outbuilding constructed of limestone (the 1904 Sanborn map indicated a small adobe structure in this location). The structure was placed with its long axis running north/south and measured $3.5 \times 7.5 \mathrm{ft}$ (Figure 4-88). Several 2-x-2-ft test units were set up to further explore what was designated Feature $A$. The test units revealed a central dividing wall constructed of the same limestone which separated the structure into two sections. It was now apparent that the feature was a "two-seater," limestone-vaulted privy. This was the largest privy discovered during the project and the only artifacts derived from the privy fill dated to shortly after the turn of the century (1900-1920). This was evidenced by the numerous ceramics which had datable maker's marks (Tennis, Volume III). From 65-70 inches below ground surface the deposit appeared to date from a slightly earlier period (1888-1896). Since many privies were periodically cleaned, the majority of the fill within this privy probably represents its last episode of use. At the lowest levels are traces of the episode before the last cleaning. (For further details regarding privies in the Alamodome area, see Brown and DeLaO, Volume III.)

\section{Trench B}

Trench B, measuring $2 \times 62 \mathrm{ft}$, was located on the north end of Lot 15. The north end of the trench was $10 \mathrm{ft}$ south of Pauly Alley and $38.6 \mathrm{ft}$ west of the west wall of 419 Cherry Street. At 4.7-9 ft south, a brick surface was encountered five inches below ground surface. An extension was made measuring $6 \times 8 \mathrm{ft}$ off the east profile to further expose the brick surface designated Feature $B$. The location of the surface corresponded roughly to the north wall of a large carriage house shown on the 1904 Sanborn map. However, examination of the bricks and their positions 


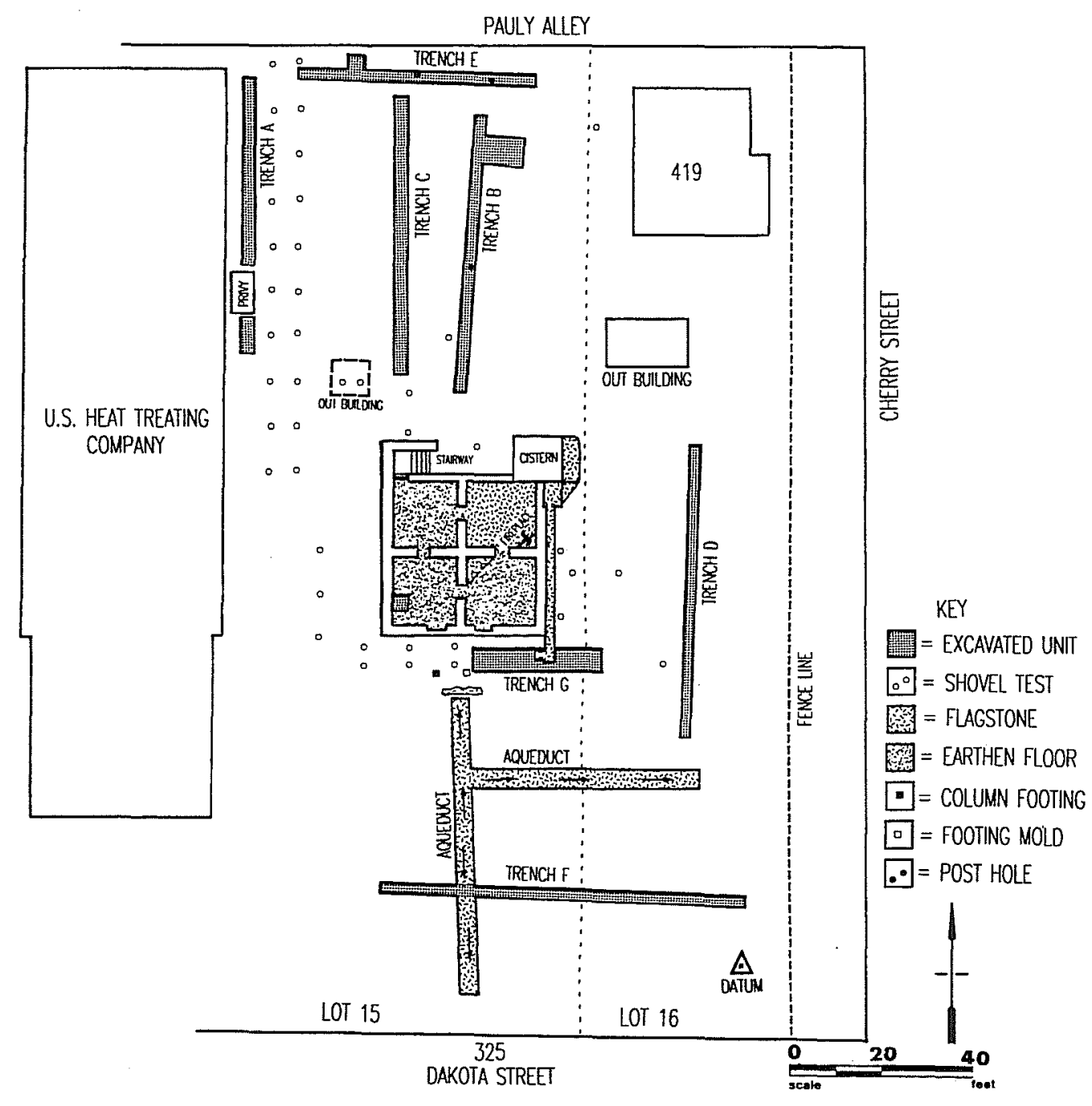

Figure 4-87. 41BX945, site plan.

later led to the conclusion that this surface was probably associated with an entrance/exit to the later 1911 carriage house. Most of the bricks composing the surface were red in color, but one SECO brick was included. The latter did not match the other bricks and may have been used to patch the surface at a later date. SECO bricks were produced in Medina County, Texas, around 1920 (Steinbomer 1983). One limestone paver was found in the west profile at approximately $14 \mathrm{ft}$ south. A post mold was present in the east profile at $26 \mathrm{ft}$ south. At $32 \mathrm{ft}$ south from about midway in the trench running west, a very deteriorated concrete surface was revealed about one inch below the ground surface and running south to $41 \mathrm{ft}$. From $41-52 \mathrm{ft}$ south, the surface was not present; at $52-60 \mathrm{ft}$ south, the concrete surface reappeared. The surface was very broken and thin in section, much charcoal and burned material was present just under the surface and solidified within it. Perhaps the ground was burned before the surface was laid down.

\section{Trench C}

The north end of this trench was located $50 \mathrm{ft}$ south of the south wall of 419 Cherry Street and $20 \mathrm{ft}$ west of the east boundary fence placed by Alamodome development. This put the trench running north/south 


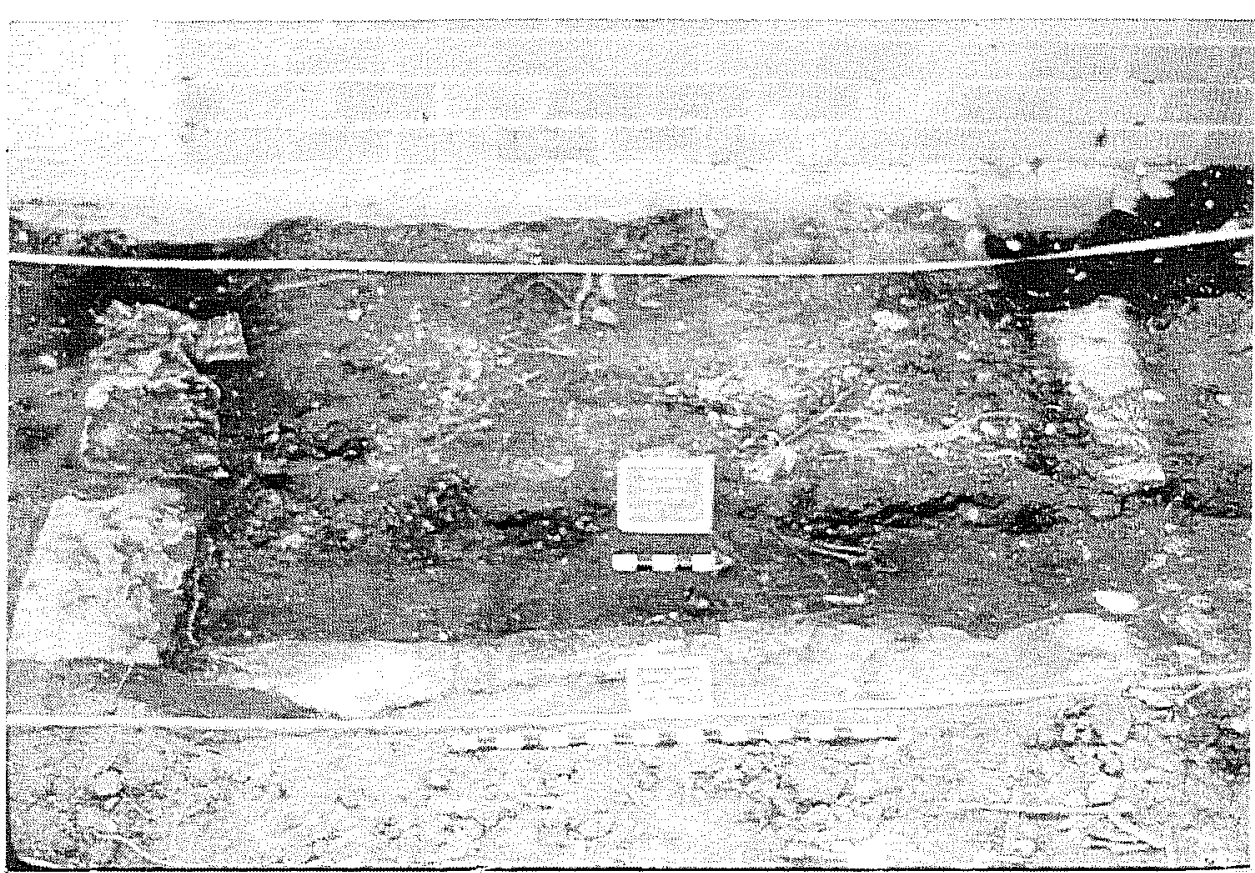

Figure 4-88. Top of Feature A, limestone-lined privy vault.

\section{Trench D}

This $2-\mathrm{x}-60-\mathrm{ft}$ trench was placed between Trenches $A$ and $B$, running north/south in an effort to provide further information on activity areas on the north side of Lot 15. The north end of the trench was located $36 \mathrm{ft} 6$ inches east of the Lot 15 west boundary line, $10 \mathrm{ft}$ south of Pauly Alley, and $54 \mathrm{ft} 6$ inches west of the west side of 419 Cherry Street.

Evidence of the floor of the 1904 carriage house was found from 8-19 ft south in this trench. A gravel fill zone was present over this area running from 1-4 inches

very close to the center of Lot 16 . The trench measured approximately $2 \times 60 \mathrm{ft}$.

Starting at $44 \mathrm{ft}$ south in this trench, at a depth varying from 4-10 inches, a very thick ferrous metal zone was present. Burned metal fragments, wire, welding rod fragments, and iron dust were all present. A "1969 D" dime was also found within this trench, just above the metal zone at a depth of three inches. After the primary dwelling was abandoned, this part of the lot may have been used as storage by U.S. Heat Treating Company. The ferrous metal deposits are similar in nature to deposits excavated just across Pauly Alley to the north on 41BX893. The deposit was widely scattered over this part of Lot 16 (see Trench $F$ below). The material was also found at 3-9 inches below ground surface in Shovel Test \#28, located $50 \mathrm{ft}$ south and six feet west of the beginning of Trench $C$.

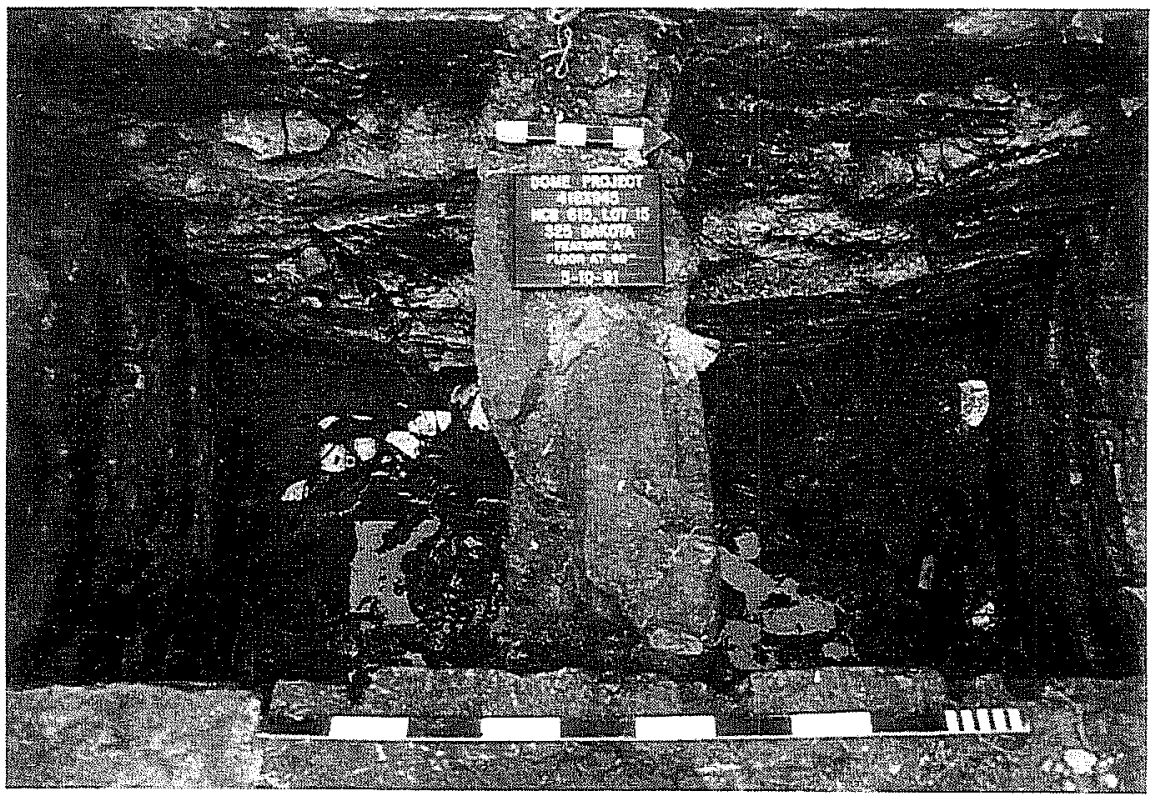

Figure 4-89. Interior view of Feature A, limestone-lined privy vault. 
The 1904 Sanborn map indicates a small outbuilding just west of this location.

\section{Trench E}

This trench was placed with an east/west orientation, just north of Trenches B and D and just south of Pauly Alley. The west end of the trench was $15 \mathrm{ft}$ east of the northwest corner of the U.S. Heat Treating Company and five feet south of Pauly Alley. Final measurements were $2 \times 52 \mathrm{ft}$. This trench was placed to provide information about the carriage house pictured in the 1911 Sanborn map. An aerial photograph (Figure 4-85) taken in the mid-1950s shows the carriage house still standing. As previously mentioned, Feature B probably represented an entrance/exit area for this structure.

Stratigraphically the trench presented a very complex profile, indicative of the possible presence of more than one structure over time. Cedar posts were found at $11 \mathrm{ft} 5$ inches west and at $32 \mathrm{ft}$ west. From $38-40 \mathrm{ft}$ west in the north profile, a large limestone block and several aligned bricks were revealed (Feature D). These could not be directly associated with any of the known structures. Artifacts from the trench revealed evidence of horse-drawn (cinch buckle, tack items) and automotive (tie rods, spark plugs) transportation in this area. Pauly Alley, immediately to the north, evidently impacted the distribution and state of preservation of features and artifacts in this trench, with all materials in a fairly mixed context.

\section{Trench F}

This trench started as a $2-\mathrm{x}-80-\mathrm{ft}$ trench running east/west across the south end of Lots 15 and 16 . The east end of the trench was located $14 \mathrm{ft}$ due north of the main site datum. From 0-31 ft west, the primary stratigraphic feature was a level of ferrous metal, clinker, and slag located 7-10 inches below ground surface. In some places this metal layer reached a thickness of eight inches.

At $62.6-64.3 \mathrm{ft}$ west and a depth of 19 inches below ground surface, a zone of limestone rubble surrounding a limestone drain was found. The drain crossed the trench running north/south and was designated Feature $\mathrm{C}$. We followed the drain to see if it connected to a second drain that had been discovered running down the east side of the remnants of the primary dwelling (325 Dakota). The first extension to trace the drain was called Feature C - North Extension. The North Extension followed the drain $40 \mathrm{ft}$ north of where it was first encountered to a point just south of a large limestone block presumed to have been the front entrance step for the primary dwelling (Figure 4-90). There the drain suddenly stopped with no evidence of any connector to the surface.

Two important features were revealed in the course of excavating this stretch: 1) about $24 \mathrm{ft}$ north, a secondary branch of the drain was revealed running east off of this main branch; and 2) just to the south of the limestone doorstep, sitting on top of the drain stones at a depth of approximately 19 inches, was an iron dinner plate with cow rib bones on it. Several other rib bones were found in association with this plate laying on top of the drain surface. It is possible that this could represent a meal consumed when the drain was being installed.

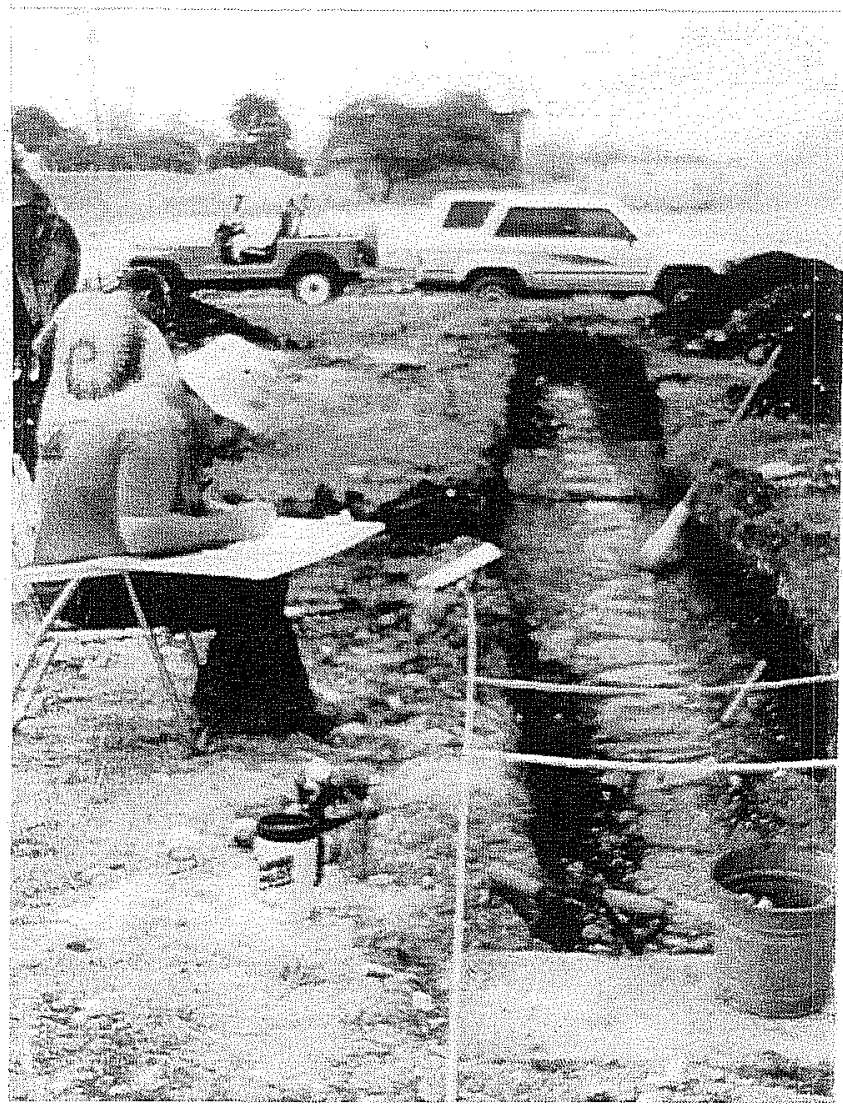

Figure 4-90. Feature $C$, drain, north/south extension. 
Once the north end of this drain was located, an extension was made to the south of Trench F (Feature C - South Extension) to see how far the drain ran in that direction. The south extension followed the drain for about $22 \mathrm{ft}$ south of Trench $F$ where it ended in what appeared to be a former ditch that had run east/west on this side of Dakota Street. The ditch had been filled, but the edges and cross section of a former earthen ditch were clearly visible in the plan and profile of the south extension trench.

We decided to follow the lateral drain (Feature C Lateral 1) which had been discovered in the North Extension running east toward Cherry Street. This was followed for about $45 \mathrm{ft}$ east until the trench came so close to the Alamodome construction area boundary fence that further excavation was precluded. This was unfortunate because if we had been able to continue the trench another $35 \mathrm{ft}$ to the east, it would probably have entered the "Valley Ditch" which we later learned ran down the east side of Lot 16 close to the road.

\section{Trench G}

This was a double-wide trench, $4-\mathrm{x}-38-\mathrm{ft}$, placed just south of the primary dwelling foundation. The west end was located six feet north of the north end of Feature C - North Extension trench. The purpose of the trench was to examine the area that would have been under the front porch of the primary dwelling. We hoped that if a connection existed between the drain running toward Dakota Street and the drain connected to the primary dwelling's cistern (Feature E, see below), that it might be found in this trench. No such connection was found. We assume an alternative method was used to channel water into the drainage system. Several large cut limestone gutters found in the excavation of the primary dwelling basement may have been used for this purpose.

A large, square post mold was found in Trench $G$, approximately five feet north of the northeast corner of the limestone doorstep. This aligned perfectly with a square, limestone column footing visible on the surface, five feet to the west. These were probably footings for columns placed on either side of the entrance doorway to the primary dwelling.

\section{Excavation of the Primary Dwelling}

When excavations began, very little of the remains of the primary dwelling were visible on the surface. The Sanborn maps showed the dwelling's location to a fair degree of accuracy; however, we did not know the extent of the house remains, or in what state of preservation they would be. After cutting down the surrounding vegetation, which was quite heavy over this portion of the lot, we encountered the apparent corner of a structure on the northeast area. A large depression was located across the central section of the area.

After locating the apparent northeast corner of the structure, we decided to start there and follow the east wall to the south. Oral history indicated that the dwelling stood until fairly recently (1975), and it had a basement (Louis Cardenas, personal communication 1991). If this was the case, then the foundation should be quite deep.

We found that what appeared on the surface to be the northeast corner of the primary structure was actually the northeast corner of a rectangular limestone cistern (Feature E) connected to the primary structure at the cistern's southwest corner (Figure 4-91). An overflow duct was still intact in the center of the north wall of the cistern. This overflow duct ran around the east wall of the cistern, feeding into a large filtration trap connected to the cistern's southeast corner. Running south from the filtration trap was a drain, located just outside the remnants of the primary dwelling's east wall.

We followed the drain to its south end, $35 \mathrm{ft}$ south of the filtration trap. At this point was an interface where a gutter from the roof of the structure would have connected to the drain. The interface had apparently undergone several modifications, as part of it was constructed of limestone and part of brick. In the course of following the cistern's drain, we lost the east wall of the primary dwelling, as the top of the limestone wall went progressively deeper. A soil break, encountered about six feet north of the drain's end, was felt to be a likely location for the primary dwelling's southeast corner. As excavation continued, it became obvious that the fill inside the structure was of extremely mixed context. Most of the items (pipes 


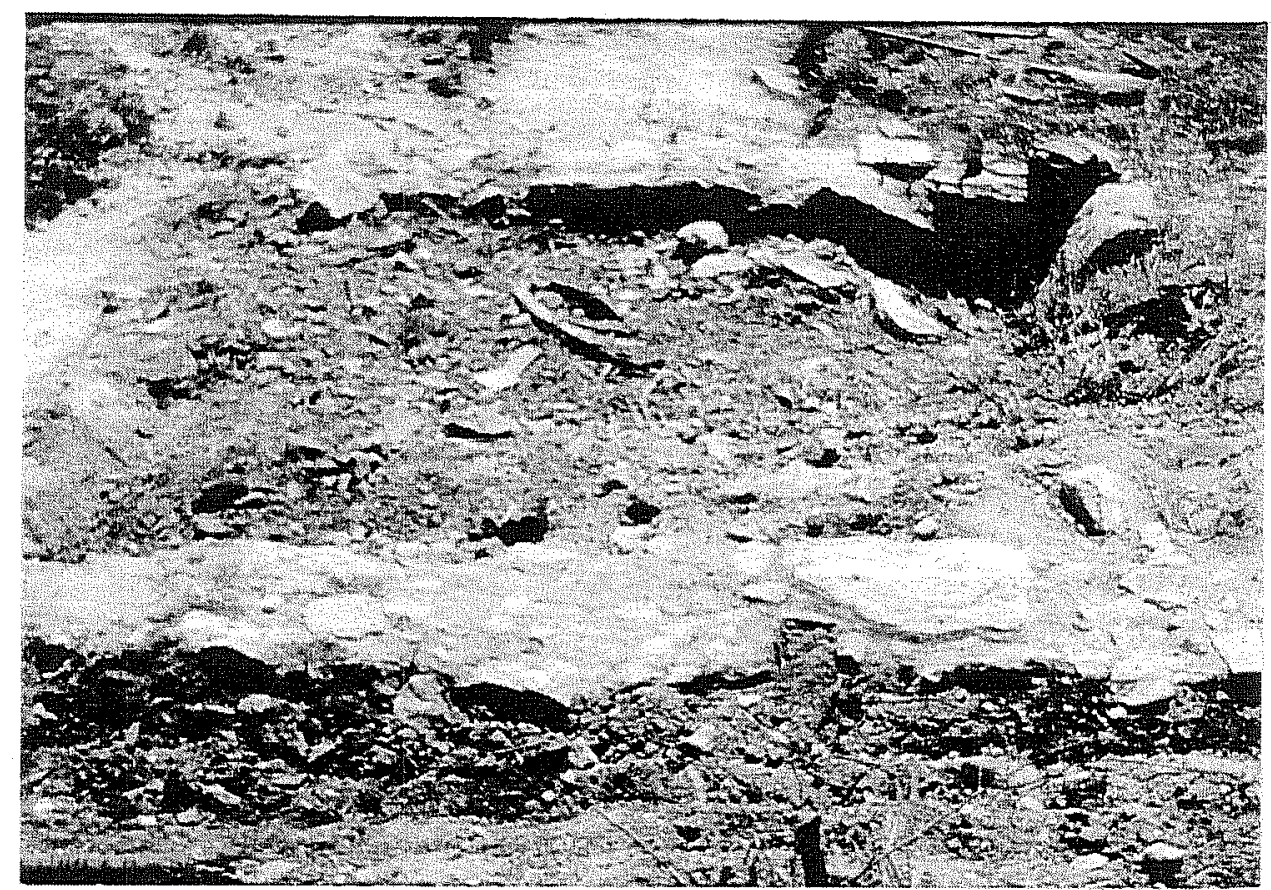

Figure 4-91. Top view of Feature E, limestone cistern set in mortar. Mold marks were present, indicating that forms were used to set the limestone and mortar. The central section of the basement was the poorest preserved of all, walls there were totally absent; however, mold marks in the floor indicated where the walls once stood. Also, small segments of the interior walls were still intact directly adjacent to each outside wall. Doorways leading into other rooms to the south and east were clearly visible, as was a possible exit in the northwest corner of the room. The floor of the room was composed of packed earth. plaster, window grates, loose limestone blocks) associated with the house itself were architectural. Much secondary refuse (Bill Miller soda cups, Dentler's potato chip bag closures, etc.) was also present. This refuse had obviously been dumped in the foundation hole fairly recently; therefore, we felt it unnecessary to excavate the interior of the structure in a tightly controlled manner.

The only other wall segment easily found from the start was the north wall running from the cistern's south side. Once this was isolated, the other walls were found by excavating to the floor of what now was an obvious basement and following the floors to a wall.

Starting in the northwest corner of the structure and moving east and south, a room measuring $15 \times 15 \mathrm{ft}$ was revealed. The walls were in a fairly poor state of preservation and were quite far (about two feet) below ground surface. The walls were constructed of limestone chunks

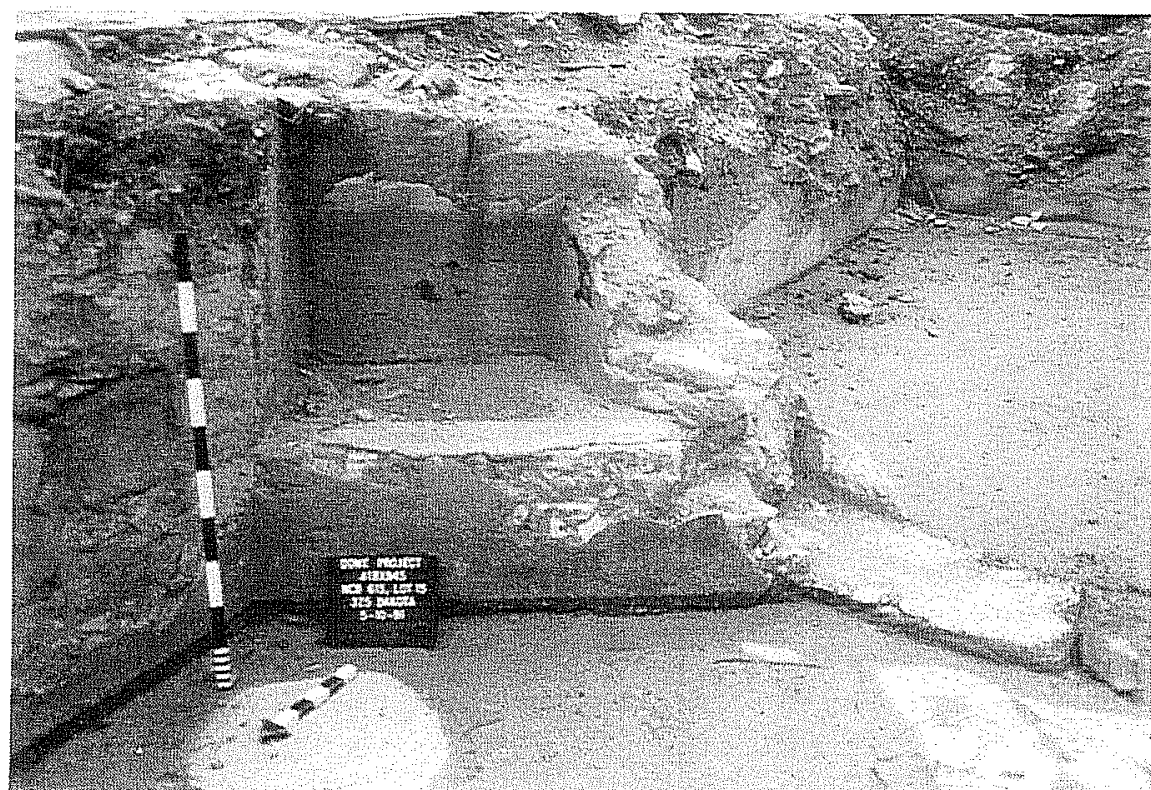

Figure 4-92. Feature I, fireplace hearth located in dwelling basement. 
limestone floor was still in a good state of preservation. The fireplace showed no direct evidence of having been used (no charcoal or smudge marks were present). No foundations remained above where there would have been a damper or flue. This room also measured $15 \times 15 \mathrm{ft}$ and doors exited to the west and south. Recent material was found all the way to floor level, with potato chip bag closures resting on the limestone floor. The Dentler Potato Chip Company had been located approximately one mile south of this location, the thousands of bag closures encountered were probably the result of dumping.

The southeast room was the next to be cleared of debris. This room was also $15 \times 15 \mathrm{ft}$ and had two features.

1) Along the south wall near the southwest corner of the room, a niche had been placed running from the floor to the top of where the foundation had been cut off. We felt that since the niche would have opened the basement to the area under the front porch, this was probably a ventilation port;

2) Evidence of a small, triangular closet was found in the northwest corner of the room, running between the exits to the north and west. The floor of this room was of packed earth, similar to that of the northwest room.

The southwest room was the last to be cleared of debris. A niche, similar to the one encountered in the previous room, was located in the southeast corner of this room. The niches were approximately four feet wide and six inches deep. The floor of this room was also of packed earth. Exits were present to the north and east. We decided to conduct a foundation depth test along the west wall, four feet from the southwest corner of the room. A 4-x-4-ft test unit was established and excavated to a point just below where it appeared that the foundation ended. The foundation base rested at $649.04 \mathrm{ft}$ amsl, or $6 \mathrm{ft} 7$ inches below the existing ground surface. The packed earth floor was $5 \mathrm{ft} 1$ inch below the existing ground surface, so it is likely that three feet of the basement extended above the ground (assuming an eight-foot ceiling) and had been destroyed along with the house proper.

Once the interiors of all four rooms were cleared of debris and exposed to floor level (Figure 4-93), we returned to the northwest room to clear the debris from what appeared to be an exit in the northwest corner. A staircase (Feature G)-running six feet to the north, where a wall was encountered, then turning east and continuing to the surface $10 \mathrm{ft}$ to the east (Figure 494)was revealed. The west wall of the primary dwelling had been lengthened to include the staircase. A small section of wall, $10 \mathrm{ft}$ long, functioning as a balustrade to protect the north side of the staircase, was placed running east/west. Only the first four risers of the stair were present. A small horizontal wood slat was recessed into the floor running across the exit doorway just before the first riser.

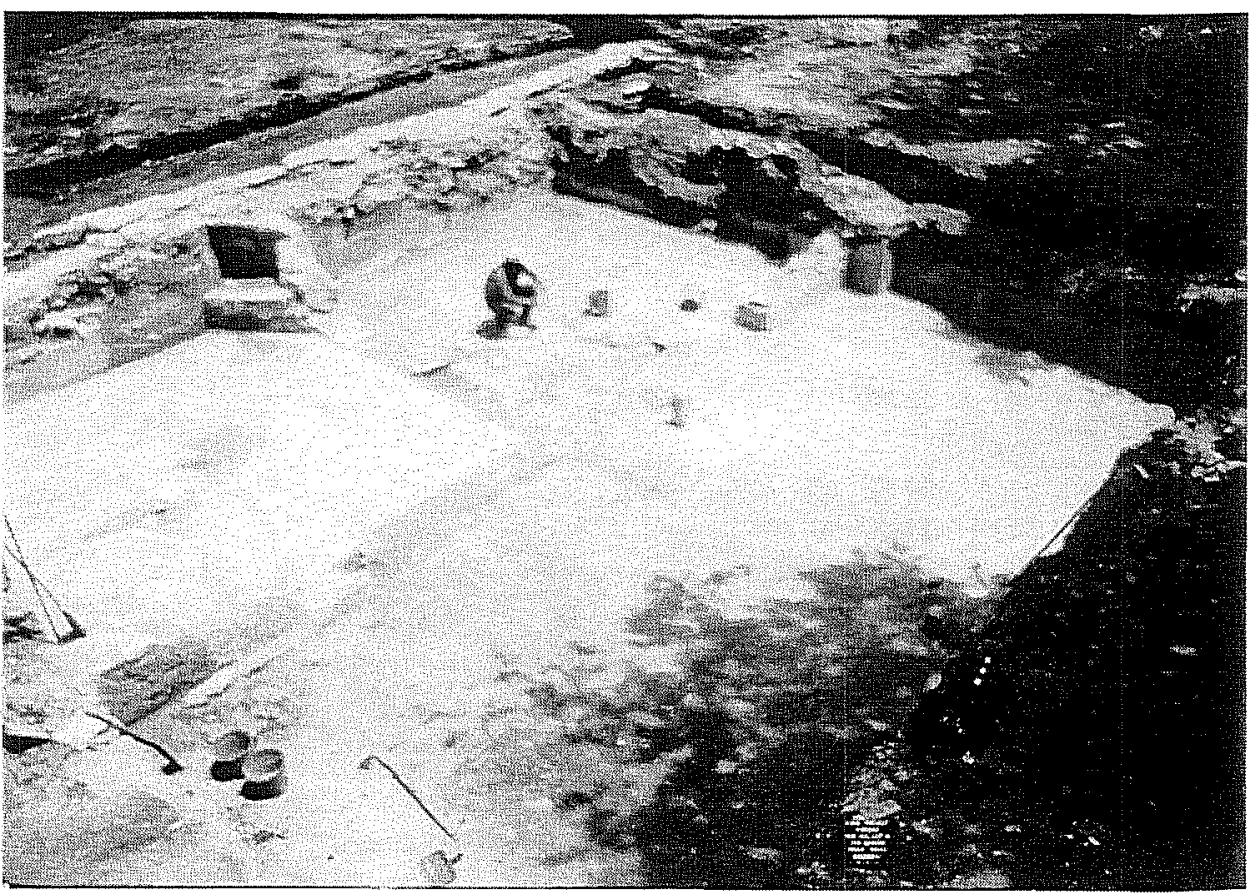

Figure 4-93. Fully exposed basement of the Pauly House. 


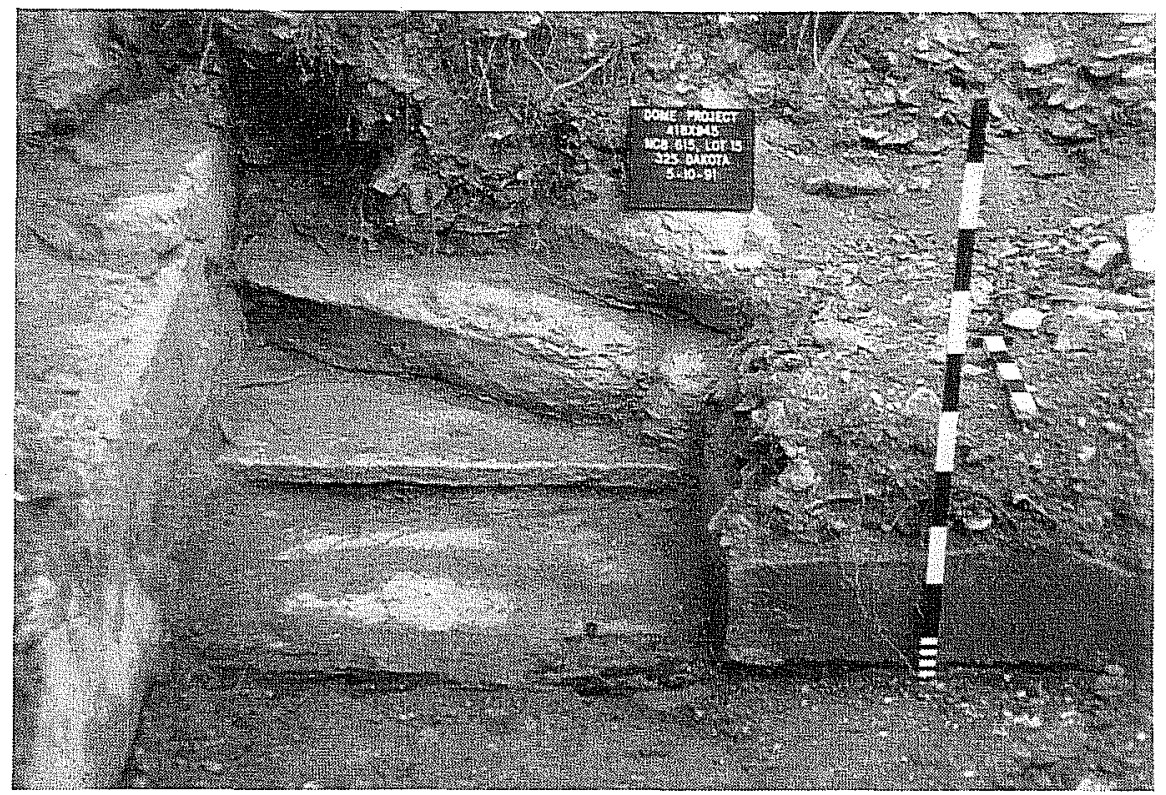

Figure 4-94. Feature $G$, staircase entering the basement. fill was in a mixed state, with early and late material in the same context (an 1892 centavo was found resting on top of a Miller Lite can). Modern debris was found to the bottom of the cistern. The cistern's bottom, at $12 \mathrm{ft}$, was heavily plastered. Capacity for the cistern would have been $873.6 \mathrm{ft}^{3}$, or 6,535 gallons. Connected to the cistern, running south from the southeast corner, was a large filtration trap. As previously mentioned, an overflow mechanism was placed to recycle water into the trap (Figure 4-95). The trap was also fed by an drain which ran north/ south from the front of where the house had stood into the south side of the trap.

The northeast quarter of the basement was the bestpreserved section, with its foundation walls closest to the surface. The western side of the basement was the worst preserved, with foundation walls well below the surface.

\section{Feature E - The Cistern}

The limestone-constructed cistern discovered on the northeast corner of the primary dwelling presented a good opportunity to learn about midnineteenth-century water systems and their technology. This is the only square/rectangular limestone cistern recorded in the San Antonio area. Such cisterns have been observed in the Fredericksburg area, all dating to the $1850 \mathrm{~s}$ (Mark Denton, personal communication 1992).

This cistern's interior measurements were $9.1 \mathrm{ft}$ east/west by eight feet north/south. The interior was lined with plaster and evidence that an arched limestone roof had covered the top was found: the top two courses of stone on the east and west sides were cut to start an arch toward the center.

The northeast quarter of the cistern interior was excavated to the foundation base. All the interior

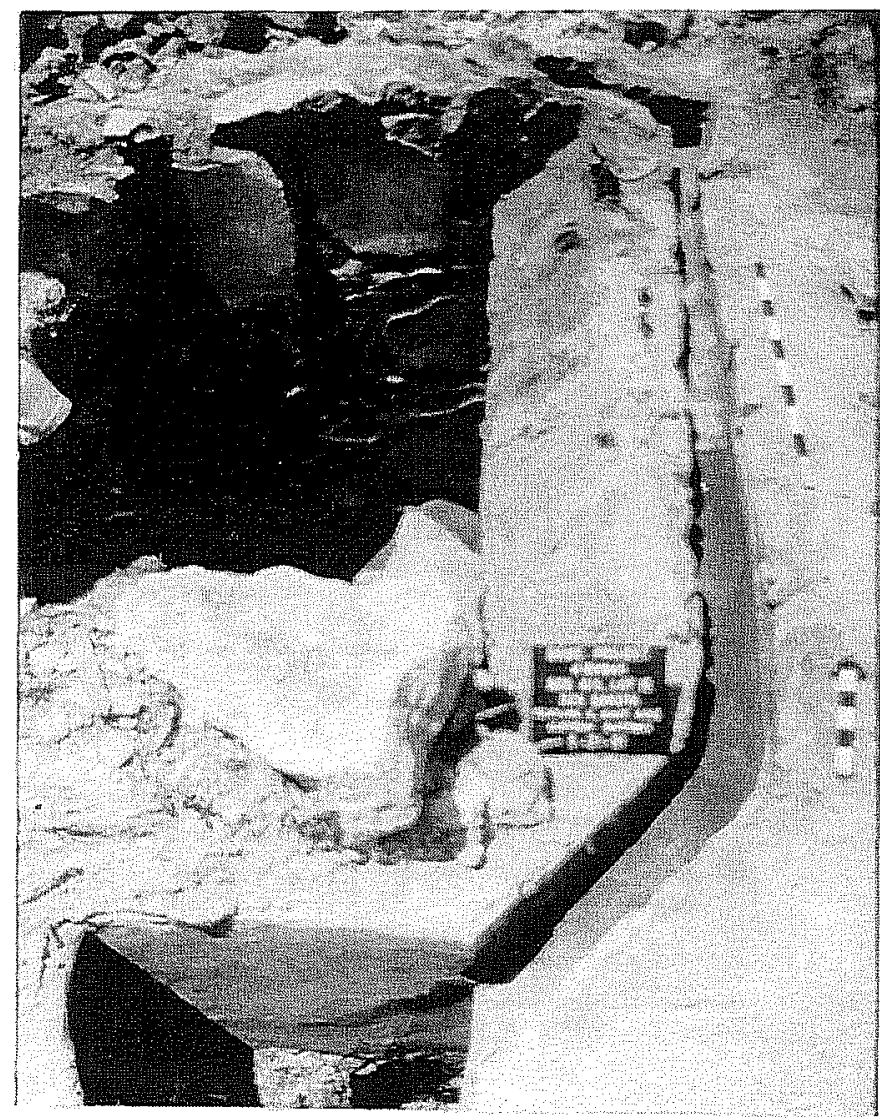

Figure 4-95. Cistern, overflow mechanism, and filtration trap. 
The drain channels running into the Pauly house cistern measured 4-6 inches wide and 5-6 inches deep. The bases of the channels were plastered and the sides and top were constructed of flat limestone pavers.

The filtration trap measured $3.75 \times 2.9 \times 4.58 \mathrm{ft}$, or $49.8 \mathrm{ft}^{3}$. Approximately two-thirds of the interior of the trap were filled with filtration material consisting of layers of sand and gravels of increasing size. The upper-most layer was a fine sand overlying a level of pea-sized gravel and charcoal. The lowest layer was of 2-3-inch-diameter cobbles. The water would enter the cistern through two apertures located in the northwest and northeast corners of the trap at the bottom. The apertures measured 10 inches tall by 8 inches wide, they were also filled with large cobbles.

This cistern filtration system is quite large in comparison with others observed in Texas. In excavations at the state capitol in 1990 by Southern Methodist University (Freuden 1990), a circular brick cistern system dating to a slightly later period (1880s) was revealed. In this case the filter measured $23.6 \times 25.6$ inches. No depth measurement was possible because the system had been truncated by later construction. The filter was completely filled with carbon, which was precluded from entering the cistern proper by a wire screen. In this case only one aperture through which water entered the cistern was present.

\section{Artifact Group Distributions And Comments}

This site was impacted by nearby industrial activity in the same way as $41 \mathrm{BX} 893$. The presence of an informal alleyway on its north side also impacted artifact distributions on that part of the site. Table 4-23 shows the artifact group percentages from the site. Figure 4-96 is based on shovel tests performed across the site. The indication is that the highest density of sheet refuse was in the northwest corner of the site. This would be in a "family back region" as described by Portnoy (1981).

This lot had also been vacant for several years and demonstrated several of the processes of site formation described by Wilk and Schiffer (1979). Trash dumping, storage/abandonment, and trail formation were all present on the site. After abandonment of the area in general, scavenging (firewood procurement) was also observed on the site.

Table 4-23. Site Artifact Frequency Distributions for 41BX945

\begin{tabular}{||l|r|r|l||}
\hline \multicolumn{1}{|c|}{ Group } & \multicolumn{1}{c|}{$\#$} & \multicolumn{1}{c|}{$\%$} & \multicolumn{1}{c|}{ Notes } \\
\hline Activity & 2,185 & 7.77 & 757 misc. metal; 530 plastic items \\
\hline Architecture & 9,549 & 33.94 & 4,783 wire nails; 1,897 window glass; 1,721 cut nails \\
\hline Arms & 24 & 0.09 & 14 cartridges; 5 gun parts; 5 shotgun shell casings \\
\hline Bone & 9,390 & 33.37 & \\
\hline Clothing & 241 & 0.86 & 135 buttons \\
\hline Furniture & 326 & 1.16 & 133 lamp parts; 80 flower pot frags.; 43 furniture parts \\
\hline Kitchen & 6,317 & 22.45 & 5,049 bottle glass frags.; 679 ceramics; 440 cans/tops \\
\hline Personal & 103 & 0.37 & \\
\hline \multicolumn{1}{r|}{ Total: } & $\mathbf{2 8 , 1 3 5}$ & $\mathbf{1 0 0}$ & \\
\hline
\end{tabular}




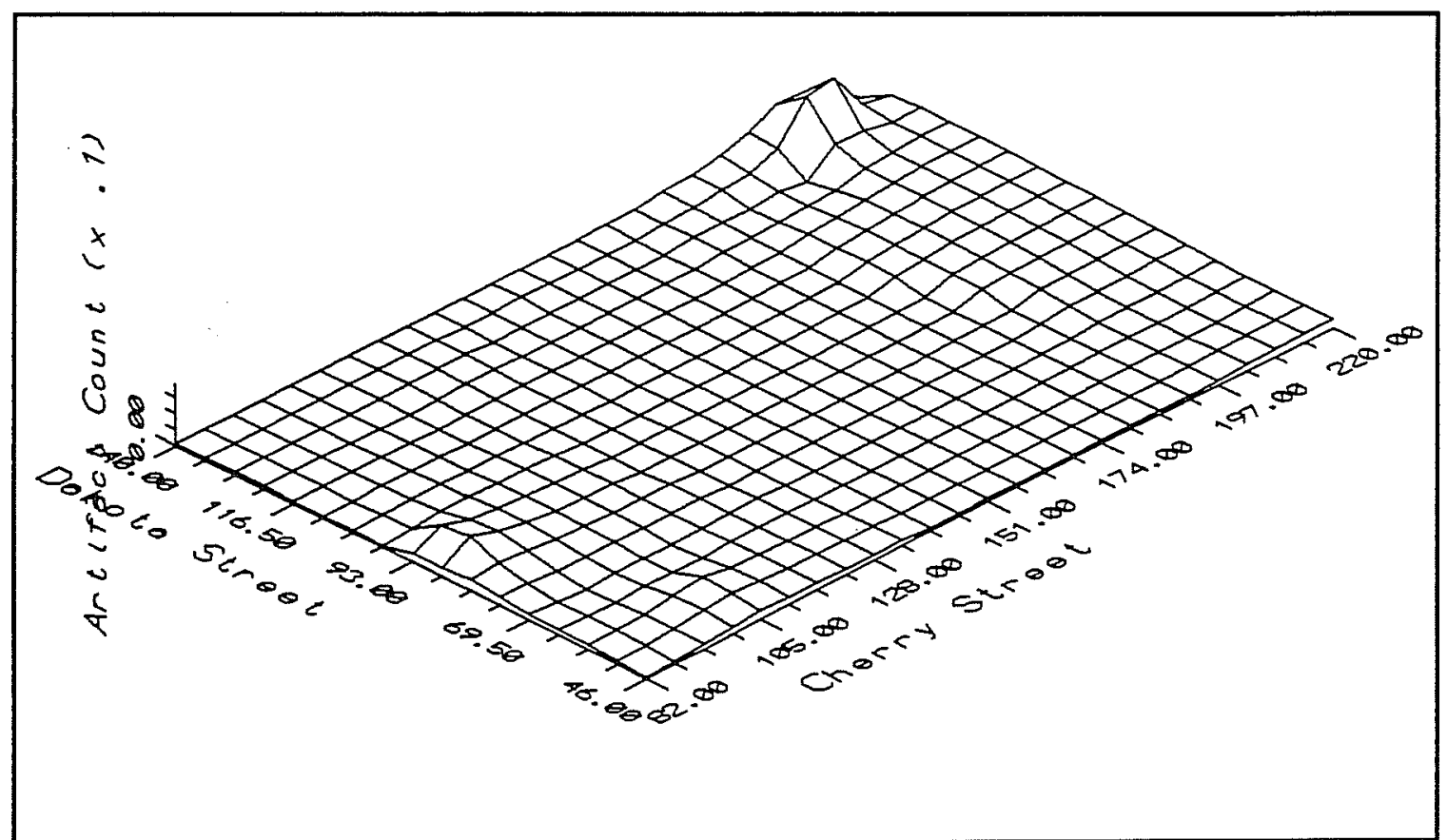

Figure 4-96. Spatial frequency of artifacts across site 41BX945, shovel test data only. 


\section{Chapter 5 \\ Artifact Frequency Analysis}

\section{Tools Used for Artifact \\ Frequency Analysis}

Most of the analysis and quantification regarding artifact frequencies and distributions from the Alamodome Project was carried out using an IBM compatible 386SX computer. The primary software tools are described below.

1) PFS First Choice - This program was used for the project data base. Basic manipulation and quantification of artifacts was possible using this program's facilities.

2) Surfer - This program allows the graphing of artifact frequencies across sites along $\mathrm{X}, \mathrm{Y}$, and $Z$ axes. In this way, artifact frequencies relating to sheet refuse or activity areas can be displayed relative to their locational occurrence on the site. Sampling strategies played an important part in determining the applicability of this program as a useful tool for site analysis. This program was used to depict artifact frequencies only where excavation employed broad coverage of the sites by shovel tests or 2-x-2-ft units. Backhoe trenches and large units were not deemed suitable for delivering data that would be representative of sheet refuse deposits, nor did they provide the coverage spread that would make such a graph accurate. Sites which were under asphalt were also excluded from this type of graphing since, in the majority of these cases, the primary excavation tool was the backhoe, and in many of the cases much of the original sheet refuse had been disturbed or removed by the introduction of the asphalt surface.
3) Microstat - This program was used to perform higher level statistical analysis than was possible by the First Choice program. Artifact group correlations, scatterplot production, and descriptive statistics were calculated using Microstat.

\section{General Hypotheses Relating to Use of Space in the Alamodome Project Area}

\section{Hypothesis 1}

The greatest concentrations of artifacts would be found toward the backs of lots, near the lot margins, close to fence lines, etc.

\section{Supported}

As displayed on the spatial graphs from 41BX881, $882,883,884,885,893,895,896$, and 945 , in all cases examined the highest densities of artifacts were derived from these areas. On sites located under asphalt surfaces this was also the case. In most cases the back corners of the lots appeared to be preferred over the lot margins.

\section{Hypothesis 2}

Supporting structures to the primary dwelling would also be found in these peripheral areas in high concentrations.

\section{Supported}

Supporting structures investigated or discovered during the course of the Alamodome Project all fell within the peripheral zones of the lots, with the exception of three structures. One was on 41BX897 (an external kitchen 
centrally located behind the primary dwelling), another was on 41BX945 (a small outbuilding positioned just off the northwest corner of the primary dwelling), and the third was on 41BX883 (a small centrally located outbuilding on the east side of the lot, Trenches $E$ and F).

\section{Hypothesis 3}

Areas directly adjacent to primary dwellings would yield lower concentrations of artifacts.

Supported

As demonstrated in the graphs referred to in Hypothesis 1, areas directly adjacent to primary dwelling tended to contain fewer artifacts than the peripheral zones of the sites. Factors that can and did affect the frequencies of artifacts within the zones adjacent to primary dwellings were observed. In cases where the lot no longer contained a dwelling and had been vacant for a significant period, activity zones were found within and adjacent to the areas where the structure had been located (such as 41BX881). Also in cases where structural damage (such as fire) had occurred, a high density of artifacts was often found directly adjacent to a structure (such as 41BX895). Therefore although generally supported, it should be realized that there are formation processes that at times significantly modify the general trends noted in this hypothesis.

\section{Hypothesis 4}

Investigations beneath the floors of pier-and-beam dwellings would yield significant deposits of artifacts.

\section{Supported}

Excavations were carried out beneath the floors of 10 pier-and-beam and one limestone structure during the course of the project. Significant quantities of artifacts were present beneath all but the limestone structures. Most of the artifacts were architectural in nature; however, the type of floor the dwelling contained, as well as the presence or absence of a surrounding apron affected the deposit of artifacts under these structures.

During Phase V excavations beneath the Demazieres house (41BX896), a limestone dwelling, only 310 artifacts were recovered. The most likely explanation for the paucity of artifacts was the type of floor in the house and the surrounding apron. The floor was constructed of interlocking boards which created a very tight floor. The outside of the house was surrounded by an apron of solid limestone making it impossible to throw trash under the house from outside.

On the other hand, sites like 41BX895 (the Garza store) contained large quantities of artifacts beneath the floors. The nature of the deposit was quite different between the household portion of the site and the store part. The floor of the grocery was of butted wooden boards, so cracks through which artifacts could were present. Periodic sweeping of the floor had over time deposited approximately 14 inches of fill beneath the store's floor, with many small artifacts (coins, safety pins, pencils) represented. The exterior of the store was not protected by an apron, allowing significant deposits of larger items (bottles, bones, metal) to be thrown under the building from the outside.

\section{Hypothesis 5}

Front parts of the lots would contain fewer artifacts and show a tendency towards ornamental and recreational pursuits.

\section{Supported}

Observation of the spatial frequency graphs confirms that in almost all cases, front yards yielded significantly fewer artifacts in lower density than back areas. All areas where front yards were present exhibited evidence of gardening activity or ornamental display. Trees and bushes present in the front yards were of more ornamental varieties (cherry, Chinese tallow, bay laurel, rose, canna, etc.) than those present in the back yards, which appeared to be directed more towards shade (pecan, live oak).

\section{Artifact Patterns as Indicators of Socioeconomic Class: A Comparison Between Alamodome and Mansberger}

As covered in Chapter 2, Mansberger (1987) compared the artifact group percentages of four sites excavated in Illinois dating to the mid-nineteenth century. Two of the sites (Hughlett and Washburn) 
were from well-to-do families, and two (Crazy Dog and Speckhardt) from less well-to-do families. Three of the sites (Hughlett, Crazy Dog, and Speckhardt) were from rural contexts, and one (Washburn) from an urban context. Mansberger presents six hypotheses concerning artifact group frequencies as they relate to socioeconomic class. Several sites excavated within the Alamodome Project lent themselves to the same kind of analysis as Mansberger's. This analysis was performed for comparative purposes.

\section{Methodology and Data Base}

Since Mansberger used four sites-two from upperand two from lower-socioeconomic contexts-in his study, the same procedure was followed in selecting a sample from the Alamodome Project. The two uppersocioeconomic class sites chosen were 41BX945 (the Pauly house) and 41BX893 (the Czernecki house). Pauly was an architect and stonemason who was active in real estate in the neighborhood of the Alamodome Project area. Czernecki was a skilled tradesman (molder) who was also active in the development of real estate within the area. The two families lived on the same block and their houses were two of the largest, most ornate dwellings in the neighborhood.

The two lower-socioeconomic group sites were 41BX941 and 41BX942. These two sites sat adjacent to one another, about three blocks south of the Czernecki and Pauly sites. These sites were small residences built and used as rental houses. The primary occupants of these houses were unskilled laborers and service-oriented workers.

Mansberger (1987) divides his artifact assemblage into nine general groups (Activity/Tool, Architecture, Arms, Clothing, Furniture, Kitchen, Personal, Transportation, and Other). The "Other" category was primarily faunal material. Mansberger's division is similar to the groups established for the Alamodome Project. Alamodome used eight categories (Activity, Architecture, Arms, Bone, Clothing, Furniture, Kitchen, and Personal). Transportation artifacts were classified with Activity group artifacts in the Alamodome assemblage, so by adding this category to Mansberger's Activity/Tool group, the two projects could be compared, since Mansberger's "Other" category was basically the same as our "Bone" group.

\section{Differences in the Samples and Possible Sources of Bias}

One of the most glaring initial differences recognized between the two projects is that three of the four sites used by Mansberger are from rural contexts, one from urban. All the sites selected from the Alamodome Project were urban in context. Differences which probably had little to do with socioeconomic status were noticed immediately. These differences are associated with the two primary contexts, urban and rural, and are discussed later in the text.

Another major difference is the time frame. All Mansberger's sites date to the mid-nineteenth century, most of the Alamodome sites date to the latenineteenth/early twentieth centuries. Between the projects the two sites which appear to have the most similarity are the Washburn site (Mansberger) and the Pauly House (Alamodome). Both are urban, uppersocioeconomic-class sites dating to the mid-nineteenth century. The Czernecki house dates to about 1890 , while 41BX941 and 942 date to $1924 / 1926$.

Environmental differences could also have a significant impact on the two project's sites. Mansberger's sites were located in west-central Illinois (upper Mississippi River environment), typified by rolling farmlands, abundant precipitation, mild summers, and long, cold winters. San Antonio, on the other hand, is located at the edge of an escarpment, with limestone hill country to the north and lowland prairie to the south. The area receives moderate precipitation and has hot summers and relatively mild winters.

Industrial growth came late to San Antonio, since the railroad did not reach the city until 1877 . Before then the city's major link with the outside world was teamster routes running from the Texas coast and Mexico. In Illinois, industrial development and the railway arrived much earlier.

\section{Results of the Comparison}

Artifact group frequencies from the compared sites are displayed in Table 5-1. The hypotheses and their results are listed below. 
Table 5-1. Comparison of Alamodome Sites with Mansberger's Sites

Higher Socioeconomic Status

\begin{tabular}{|c|c|c|c|c|c|c|c|}
\hline \multirow{2}{*}{$\begin{array}{l}\text { Artifact } \\
\text { Group }\end{array}$} & \multicolumn{3}{|c|}{ Alamodome Project } & \multicolumn{3}{|c|}{ Mansberger (1987) } & \multirow{2}{*}{$\begin{array}{l}\text { Diff. of } \\
\text { Means }\end{array}$} \\
\hline & 41BX945 & 41BX893 & Mean & Hughlett & Washburn & Mean & \\
\hline Activity & 7.72 & 9.49 & 8.61 & 0.05 & 0.10 & 0.08 & 8.53 \\
\hline Architecture & 33.76 & 35.93 & 34.85 & 48.50 & 37.10 & 42.80 & -7.95 \\
\hline Arms & 0.08 & 0.22 & 0.15 & 0.10 & 0.10 & 0.10 & 0.05 \\
\hline Bone & 33.20 & 17.46 & 25.33 & 4.20 & 20.60 & 12.40 & 12.93 \\
\hline Clothing & 0.85 & 0.80 & 0.83 & 0.20 & 0.30 & 0.25 & 0.58 \\
\hline Fumiture & 1.15 & 0.13 & 0.64 & 2.20 & 2.70 & 2.50 & -1.86 \\
\hline Kitchen & 22.33 & 35.03 & 28.68 & 34.00 & 36.10 & 35.00 & -6.32 \\
\hline Personal & 0.36 & 0.58 & 0.47 & 5.60 & 2.70 & 4.20 & -3.73 \\
\hline
\end{tabular}

Lower Socioeconomic Status

\begin{tabular}{|c|c|c|c|c|c|c|c|}
\hline \multirow{2}{*}{$\begin{array}{l}\text { Artifact } \\
\text { Group }\end{array}$} & \multicolumn{3}{|c|}{ Alamodome Project } & \multicolumn{3}{|c|}{ Mansberger (1987) } & \multirow{2}{*}{$\begin{array}{l}\text { Diff. of } \\
\text { Means }\end{array}$} \\
\hline & 41BX941 & $41 B \times 942$ & Mean & Crazy Dog & Speckhardt & Mean & \\
\hline Activity & 7.21 & 3.36 & 5.28 & 0.15 & 0.10 & 0.13 & 5.15 \\
\hline Architecture & 35.41 & 38.53 & 36.97 & 21.60 & 27.60 & 24.60 & 12.37 \\
\hline Arms & 0.00 & 0.06 & 0.03 & 0.00 & 0.00 & 0.00 & 0.03 \\
\hline Bone & 4.67 & 4.74 & 4.71 & 14.20 & 4.10 & 9.15 & -4.43 \\
\hline Clothing & 0.40 & 0.58 & 0.46 & 0.40 & 0.10 & 0.25 & 0.21 \\
\hline Furniture & 1.33 & 0.19 & 0.76 & 0.90 & 0.70 & 0.80 & -0.04 \\
\hline Kitchen & 50.12 & 45.66 & 49.89 & 61.50 & 66.00 & 0.64 & -13.86 \\
\hline Personal & 0.81 & 0.84 & 0.82 & 1.10 & 1.20 & 1.15 & -3.28 \\
\hline
\end{tabular}

Hypothesis 1

Households of upper-class status will be represented archaeologically by lower percentages of kitchen items. This will be reflective of non-food related spending by these groups.

\section{Mansberger: Supported}

Average upper-class kitchen group was 35 percent versus average lower-class kitchen group of 65 percent. Earnst Engel's laws of expenditures for food are given, 1) "The poorer the family the higher the proportion of its income is spent on food," and 2) family expenses are first appropriated to the necessities of staying alive, and luxury spending and saving occurs only at higher income levels (Zimmerman 1932).

\section{Alamodome: Supported}

The average upper-class kitchen percentage was 28.68 percent, while the lower-income group average was 49.89 percent.

Hypothesis 2

Architecture group artifacts will be lower at sites occupied by lower-income folks. This will be reflective of the more ephemeral nature of the lowerclass structures. 


\section{Mansberger: Supported}

Lower-socioeconomic sites produced much lower levels of architectural items than the uppersocioeconomic group sites (lower 24.6 percent, upper 42.8 percent). Most of the architectural items were window glass and nails.

\section{Alamodome: Not supported}

The lower-socioeconomic group sites tended to have slightly higher proportions of architectural items (lower 36.97 percent, upper 34.85).

Several possible explanations for this occurrence exist. The ephemeral nature which Mansberger asserts as typifying the lower-socioeconomic household argues for a greater likelihood of that structure entering the archaeological context than a well-built, solid structure. Three of the four structures used in the Alamodome comparison were of pier-and-beam construction. Neither lower-socioeconomic dwelling still existed on the sites. The Czernecki house was present and, although having been ravaged by fire, was still quite intact on the outside. The Pauly residence was built of limestone; therefore, one might expect fewer nails to be employed in the construction. In this case, however, other architectural debris such as plaster and limestone would likely replace the nails in the archaeological record.

The time element probably also played a part, as certain items such as wood and shingles might not preserve well over time. It should also be noted that in the Alamodome sites the primary architectural artifacts present were window glass and nails.

\section{Hypothesis 3}

The percentage of furniture-related items would be higher in upper-socioeconomic sites, reflective of more money spent on these items, as well as of the difference between "cheap" furniture and more ornate, better-built furniture.

\section{Mansberger: Supported}

Upper-socioeconomic group 2.5 percent, Lowersocioeconomic group .8 percent.

\section{Alamodome: Not supported}

Upper-socioeconomic group .64 percent, Lowersocioeconomic group .76 percent.
Mansberger notes that not much difference is seen between the upper and lower ends of the spectrum regarding the furniture group. In the case of the Alamodome, the lower-income sites are slightly better represented. Several formation processes could be involved in producing these results. Mansberger argues that more ornate furniture would tend to preserve better in archaeological contexts than "cheap" furniture, but this better-quality furniture by its very nature would tend to enter the archaeological record less frequently. Items of this type would tend to be repaired, reused, or laterally cycled (e.g. stay in systemic context) rather than being discarded. One would expect cheaper furniture would suffer a greater frequency of irreparable damage and through disposal find its way into the archaeological record more often. Once there it might not preserve as well; however, the greater quantity would insure some representation archaeologically. Again, time could be a factor. Even a well-made piece of furniture deposited in the ground might not last the time between the mid-nineteenth century and the present, compared with a poorer quality piece of furniture deposited in the 1920 s which might.

\section{Hypothesis 4}

Arms-related artifacts would not be reflective of socioeconomic status in the Midwest during the midnineteenth century. Rural sites would be expected to contain higher percentages of arms artifacts reflective of more emphasis on hunting in those locations.

\section{Mansberger: Supported}

Notation is made that none of the sites examined contained more than .1 percent proportion of armsrelated artifacts. No real significance was found between the two groups, although the upper-income group did show a slightly higher percentage of armsgroup artifacts. No significance was noted between rural and urban groups.

\section{Alamodome: Supported}

As in Mansberger (1987), slightly higher proportions of arms-related artifacts were noted in uppersocioeconomic sites (upper .15 percent, lower .03 percent). In some well-sampled sites, percentages were as high as .55 percent (41BX890). Although hunting is not carried out as frequently in urban contexts as in rural, firearms are still utilized in different roles in urban areas (target shooting, plinking, crime, noise 
making, etc.). Also the greater population density in an urban area allows for a greater chance of firearmsrelated artifacts being present within a given area. Further research is needed in this area.

\section{Hypothesis 5}

The percentage of Activity/Tool-related artifacts will be higher in lower-socioeconomic households reflective of the differential amount of time spent on manual labor by the two groups.

\section{Mansberger: Not supported}

Notation was made that less than .1 percent of this artifact group was present within the sites examined. Heitzman (1980) reports recording tool percentages as high as eight percent from frontier sites on the great plains.

\section{Alamodome: Not supported}

Tools were placed within the activity group of artifacts in the Alamodome Project, where they formed a large part of the percentage within that group. In this case, upper-socioeconomic households had 8.61 percent activity group, while lower-socioeconomic households produced 5.28 percent. In the case of the Alamodome sites, the reasons behind the numbers are fairly evident. This was a working class, industrial neighborhood overall. The individuals who were making the highest wages were the skilled craftsmen who worked with their hands. The lower-income groups also worked with their hands, but in unskilled and service jobs. Therefore, activity/tool group artifacts were common to both groups of sites, but more common on the sites where industrial skill was known and practiced.

\section{Hypothesis 6}

Percentage of clothing and personal group items would be higher in upper-socioeconomic groups reflective of greater amounts of money spent for such items.

\section{Mansberger: Not supported}

The clothing group did not appear to be a significant indicator of socioeconomic status in this study. All sites had less than .4 percent represented in this group. Personal group artifacts had percentages of 4.2 at upper-income sites, and 1.2 at lower-income sites, which tends to support that part of the hypothesis.

\section{Alamodome: Not supported}

Clothing percentages recorded during the Alamodome study tend to support Mansberger's hypothesis (upper .83 percent, lower .5 percent); however, one must examine this data more closely. In the Milwaukee garbage project, Thompson and Rathje (1982) found that textiles were discarded at very high rates within low income areas. The theory was that high income groups would discard little clothing, but laterally cycle it through various reuse mechanisms. Items in poor neighborhoods would finally wear out and be discarded.

In examining button frequencies from the Alamodome Project, we see that 41BX945 (the Pauly house) produced 135 buttons; however, all but four of these came from a single feature (a limestone privy). The four buttons found in non-feature context were the product of $2,060 \mathrm{ft}^{3}$ of excavated soil. On the other hand, Trench D from the Runge Street excavations (which included 41BX941 and 942) produced 39 buttons from non-feature context (for $568 \mathrm{ft}^{3}$ excavated). This was one of the highest densities of buttons for the entire project ( .07 buttons per $\mathrm{ft}^{3}$ ). One interpretation for this data is that both high- and lowincome groups were disposing of clothing; however, the mechanisms of disposal were such that they put the remains into different contexts. If only the non-feature data were present, then the percentages of clothing items between upper- and lower-income groups would reverse.

Regarding personal items, Mansberger's hypothesis was not supported by the Alamodome data (upper .47 percent, lower .82 percent). One possible explanation for this is that after the turn of the century (particularly post-World War II), low-cost personal items made of plastic and other inexpensive materials became more available to low-income groups than ever before. Because of the low cost and cheap construction of these items, less attention was paid to reuse or lateral cycling of these items; thus they would find their way into the archaeological record in greater quantities. Most of the personal items recovered in the Alamodome excavations fall into this category. 


\title{
Chapter 6
}

\section{Identification of Site Formation Processes at the Alamodome}

\author{
Kevin J. Gross
}

\section{Introduction}

The previous chapter considered the spatial patterning of artifacts at individual Alamodome sites, this chapter presents an inter- and intrasite comparative approach to site formation processes. Excavation units at the Alamodome were standardized into spatial units to identify intrasite organization and spatial artifact patterns. The spatial units allowed us to compare similar areas from different sites. In a similar analysis, Rubertone (1982:129) suggests, "the assumption underlying the classification of provenience units into categories of depositional types was that the accumulations of artifacts and other debris within the subsurface fills comprising the urban archaeological site were the result of different processes affecting land use and site formation."

The proportional distribution of artifacts by depositional type is first considered. Next, a more rigorous examination, using analyses of adjusted residuals, was completed for the entire project area and, separately, for two intensively excavated sites: 41BX896 (Demazieres) and 41BX945 (Pauly). The adjusted residual data allows us to detect statistically significant inter- and intrasite differences in artifact distributions. Our analysis attempts to explain what differences result from formation processes and then, more importantly, what differences exist because of behavioral processes. Architectural artifacts were considered in the proportional distribution, but were excluded from the adjusted residual analysis because they were not collected systematically across the project area. (Representative grab samples of highquantity architectural artifacts, especially nails, were frequently collected. A complete collection would have increased the proportion of architectural artifacts while simultaneously and uniformly decreasing the proportion of all other artifact groups.)

The formation processes at historic urban sites are complex. Influences on these processes include city ordinances intended to protect public health through improved sanitation (including refuse removal), changing site and lot boundaries, multiple occupations, functional changes of outbuildings, and changing cultural and individual yard use preferences. Cressey and Stephens (1982:53), nonetheless, believe that "domestic zones" associated with specific activities can be identified at historic sites. These zones frequently represent "past behavior since . . . different contexts [reflecting activities] are non-randomly located" (Cressey and Stephens 1982:53). Although Kent (1984:9) suggests that activity areas are monofunctional, the limited space at urban sites and the reoccupation of such sites may cause activity areas to overlap. Recent ethnoarchaeological research has, in fact, suggested that different activities are often performed at the same place (O'Connell 1987:74-75). We are less interested in documenting individual areas related to single activities. Instead, this analysis looks at larger, more general spatial units in an attempt to identify relationships between different intrasite areas to understand the overall domestic land usage at sites. 


\section{Spatial Units}

Seven depositional types were used at the Alamodome. The units are modified from Rubertone's (1982) study of spatial organization at historic sites in the Roger Williams National Memorial in Providence, Rhode Island. Not all the Alamodome sites had each depositional type, as the research goals and amount of excavation varied at individual sites. Table 6-1 summarizes the presence and absence of depositional types at each of the 36 Alamodome sites. Initially, we wanted to calculate the volume of soil excavated from each type to allow for weighted comparisons of artifact counts. Unfortunately, many of the units were excavated across multiple depositional types and because of the variety of excavation units used (e.g. mechanical trenches, hand-excavated $2-\mathrm{ft}-\mathrm{x}-2-\mathrm{ft}$ and 4-ft-x-4-ft units, and shovel tests), it was impossible to create accurate estimates of soil volumes. Thus, the following discussion is limited to general observations about the proportional distribution of artifacts. Artifact counts in this section vary from those presented in other sections of this report because this analysis excluded unprovenienced surface collected items and artifacts recovered from the interiors of existing structures. Tables 6-2 and 6-3 summarize the distribution of artifacts by count and proportion and depositional type for all excavated sites in the Alamodome project area. The seven depositional types are described below.

\section{Beneath Primary Dwelling}

This depositional type included areas excavated beneath primary dwellings. With the exception of one site, 41BX896 (Demazieres), all the houses had been destroyed or demolished. The Department of Antiquities Protection requested that CAR archaeologists return to excavate units beneath the floor of the Demazieres house (Phase V). Since such a small number of artifacts was recovered from the Phase $V$ excavations, it seemed unproductive to create a separate depositional type. Units beneath the primary dwelling were excavated at nine sites: 41BX881, 41BX882, 41BX895, 41BX896, 41BX897, 41BX900, 41BX936, 41BX943, and 41BX945. Architectural artifacts, as expected, were the most frequently recovered objects (representing 53.22 percent of all artifacts recovered) from this depositional type.
However, because of the generally low density of artifacts from units beneath primary dwellings, only 9.86 percent of all architectural artifacts recovered from the project area were recovered in this depositional type. The lowest proportion of kitchenrelated artifacts were recovered from this spatial unit. For all sites, 6,889 artifacts (5.0 percent of all recovered artifacts) were excavated from beneath primary dwellings.

\section{Primary Dwelling Foundations}

CAR archaeologists exposed primary dwelling foundations to locate no longer existing houses. Foundations were excavated at the following six sites: 41BX895, 41BX896, 41BX898, 41BX899, 41BX900, and 41BX945. These deposits should, theoretically, contain materials mostly from when the house was constructed since the deposits would have been capped by the house superstructure. Few artifacts $(n=530)$ were recovered in this depositional type (representing less than one percent of all artifacts recovered from the project area). However, the highest proportions of clothing (2.08 percent) and personal (1.89 percent) artifacts were recovered from foundation units.

\section{Two Meters Adjacent to the Primary Dwelling}

This analytic unit was arbitrarily selected. It assumes that individuals use areas immediately adjacent to the primary dwelling differently than other areas of the site. For example, ethnoarchaeologists have documented areas adjacent to living areas that were maintained as non-disposal areas (Graham 1994; Kent 1984, 1991; and Windes 1987). Units were excavated in this spatial unit at 13 sites: 41BX881, 41BX882, 41BX883, 41BX884, 41BX885, 41BX893, 41BX894, 41BX895, 41BX896, 41BX897, 41BX936, 41BX940, and 41BX945. Artifacts excavated from units in this depositional type comprise 7.11 percent $(n=7,106)$ of all artifacts recovered from the project area.

\section{Outbuildings}

Archival research reveals that many outbuildings at the Alamodome were converted to secondary dwellings (rentals) late in the history of the structure (see the site 
Table 6-1. Excavated Depositional Types at Alamodome Sites

( $\mathrm{Y}$ indicates that depositional was excavated)

\begin{tabular}{|c|c|c|c|c|c|c|c|}
\hline$\frac{\dot{x}}{\sigma}$ & 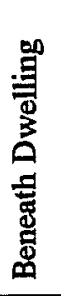 & 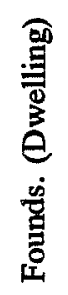 & 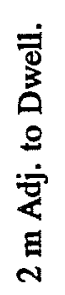 & 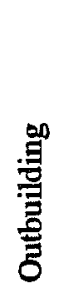 & 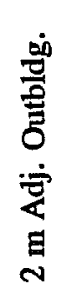 & $\underset{\nu}{\vec{Z}}$ & 胥 \\
\hline 881 & $Y$ & & $\mathrm{Y}$ & & $Y$ & $\mathrm{Y}$ & \\
\hline 882 & $Y$ & & $\mathrm{Y}$ & $\mathbf{Y}$ & $\mathrm{Y}$ & $Y$ & \\
\hline 883 & & & $\mathbf{Y}$ & $\mathrm{Y}$ & $Y$ & $\mathrm{Y}$ & $\mathbf{Y}$ \\
\hline 884 & & & $\mathrm{Y}$ & $Y$ & $Y$ & $\mathbf{Y}$ & \\
\hline 885 & & & $\mathbf{Y}$ & $\mathbf{Y}$ & & $Y$ & \\
\hline 890 & & & & & & & $\mathrm{Y}$ \\
\hline 891 & & & & & & $\mathrm{Y}$ & $Y$ \\
\hline 892 & & & & & & & $Y$ \\
\hline 893 & & & $\mathrm{Y}$ & $\mathrm{Y}$ & $\mathrm{Y}$ & $\mathrm{Y}$ & \\
\hline 894 & & & $\mathbf{Y}$ & & & $\mathrm{Y}$ & \\
\hline 895 & $Y$ & $\mathbf{Y}$ & $\mathrm{Y}$ & $\mathrm{Y}$ & $\mathrm{Y}$ & & $Y$ \\
\hline 896 & $\mathrm{Y}$ & $\mathrm{Y}$ & $\mathrm{Y}$ & $Y$ & $\mathrm{Y}$ & $\mathrm{Y}$ & $\mathrm{Y}$ \\
\hline 897 & $\mathrm{Y}$ & & $\mathrm{Y}$ & $\mathbf{Y}$ & $\mathrm{Y}$ & $\mathrm{Y}$ & $Y$ \\
\hline 898 & & $Y$ & & & & & \\
\hline 899 & & $\mathrm{Y}$ & & & & 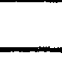 & \\
\hline 900 & $Y$ & $\mathrm{Y}$ & & & & $\mathrm{Y}$ & $\mathrm{Y}$ \\
\hline 926 & & & & & & & $\mathbf{Y}$ \\
\hline 927 & & & & & & & $\mathrm{Y}$ \\
\hline 928 & & & & & & & $\mathrm{Y}$ \\
\hline 929 & & & & & & & $Y$ \\
\hline 930 & & & & & & $\mathrm{Y}$ & $\mathrm{Y}$ \\
\hline 931 & & & & & & & $\mathrm{Y}$ \\
\hline 932 & & & & & & & $Y$ \\
\hline 936 & $Y$ & & $\mathrm{Y}$ & & & & \\
\hline 937 & & & & & & $\mathrm{Y}$ & $\mathrm{Y}$ \\
\hline 938 & & & & $\mathrm{Y}$ & & $Y$ & \\
\hline 939 & & & & & & $Y$ & \\
\hline 940 & & & $Y$ & & & & \\
\hline 941 & & & & & & $\mathrm{Y}$ & \\
\hline 942 & & & & & & $\mathrm{Y}$ & $Y$ \\
\hline 943 & $Y$ & & & & & & \\
\hline \multicolumn{8}{|l|}{944} \\
\hline 945 & $Y$ & $\mathrm{Y}$ & $\mathrm{Y}$ & $\mathrm{Y}$ & $Y$ & $\mathrm{Y}$ & $\mathbf{Y}$ \\
\hline \multicolumn{8}{|l|}{955} \\
\hline \multicolumn{8}{|l|}{956} \\
\hline 957 & & & & & & & \\
\hline
\end{tabular}


Table 6-2. Distribution of Artifacts by Depositional Type

\begin{tabular}{|c|c|c|c|c|c|c|c|c|c|}
\hline & 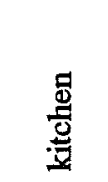 & ๕̊ & 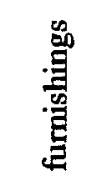 & 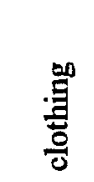 & 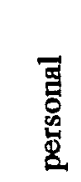 & 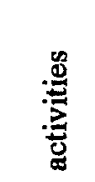 & 总 & 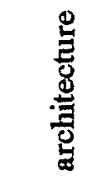 & 吾 \\
\hline beneath primary dwelling & 1770 & 878 & 76 & 83 & 62 & 333 & 21 & 3666 & 6889 \\
\hline primary dwelling foundations & 143 & 81 & 7 & 11 & 10 & 29 & 0 & 249 & 530 \\
\hline $2 \mathrm{~m}$ adjacent to primary dwelling & 1892 & 987 & 68 & 93 & 74 & 364 & 17 & 3611 & 7106 \\
\hline outbuilding & 5810 & 1864 & 113 & 336 & 85 & 730 & 20 & 6844 & 15802 \\
\hline $2 \mathrm{~m}$ adjacent to outbuilding & 793 & 556 & 10 & 28 & 20 & 168 & 7 & 1261 & 2843 \\
\hline yard areas & 8748 & 5863 & 133 & 220 & 145 & 1001 & 30 & 9688 & 25828 \\
\hline midden & 13530 & 12514 & 1235 & 354 & 146 & 1161 & 139 & 11875 & 40954 \\
\hline total & 32686 & 22743 & 1642 & 1125 & 542 & 3786 & 234 & 37194 & 99952 \\
\hline
\end{tabular}

Table 6-3. Proportional Distribution of Artifacts by Depositional Types

description of 41BX883, for example). Archaeological units were located within the foundations of either existing or previously existing outbuildings. The changing function of some outbuildings from workshops or storage spaces to secondary dwellings (usually rentals) made deposits associated with this depositional type difficult to interpret. One would expect different classes of artifacts to accumulate as the building changed in function. For instance, deposits from the earlier barn and shop functions should produce more artifacts from the activity and architectural artifact groups, and artifacts reflecting the later domestic uses of the building would have more artifacts from the kitchen and furniture groups. Since there was typically little depth to these deposits, we believed that artifacts from outbuildings would produce unique proportional patterns. Outbuildings were excavated at 10 sites: $41 \mathrm{BX} 882,41 \mathrm{BX} 883,41 \mathrm{BX} 884$, 41BX885, 41BX893, 41BX895, 41BX896, 41BX897, $41 \mathrm{BX} 938$, and $41 \mathrm{BX} 945$. A total of 15,802 artifacts 
(15.81 percent of all artifacts) was recovered in units from this depositional type. The highest proportion of kitchen artifacts (36.77 percent) and the lowest proportion of animal bone (11.80 percent) were observed within this depositional type. It is also interesting to note that 29.87 percent $(n=336)$ of the clothing assemblage was recovered from outbuilding units.

\section{Two Meters Adjacent to Outbuildings}

As the function of outbuildings changed over time, as described above, the activities and depositional patterns around outbuildings may have also changed. The twometer increment was again arbitrarily selected to detect these assumed differences. This spatial unit was investigated at nine sites: 41BX881, 41BX882, 41BX883, 41BX884, 41BX893, 41BX895, 41BX896, 41BX897, and 41BX945. Artifacts excavated from units in this depositional type accounted for 2.84 percent $(n=2,843)$ of all artifacts. The lowest proportions of furnishing artifacts $(0.35$ percent) and the highest proportions of activity artifacts (5.91 percent) were recovered from units two meters adjacent to outbuildings.

\section{Fill/Other (Yard)}

These units include all other yard areas not previously described. The large quantity of artifacts recovered from yard areas $(n=25,828$ or 25.84 percent of all artifacts) reflect excavation strategies and not the intensity of deposits. Simply put, more units were excavated in yard units than in any other depositional type. Yard units contained lowest proportion of artifacts from the clothing group ( 0.85 percent). Yard units were excavated at 18 sites: 41BX881, 41BX882, 41BX883, 41BX884, 41BX885, 41BX891, 41BX893, 41BX894, 41BX896, 41BX897, 41BX900, 41BX930, 41BX937, 41BX938, 41BX939, 41BX941, 41BX942, and 41BX945.

\section{Middens}

Middens were defined by intensive, repetitive deposition of trash in a limited or confined space. Most, but not all, of our identified middens were abandoned privies and wells. The greatest quantities of artifacts were recovered from midden units ( $n=40,954,40.97$ percent of all artifacts); a majority of every artifact assemblage was recovered from middens. However, middens contained the lowest proportions of architectural (29.00 percent), personal ( 0.36 percent), and activities ( 2.83 percent) artifacts. But the largest proportions of furnishing artifacts (3.02 percent), arms-related artifacts ( 0.34 percent), and animal bone ( 30.56 percent) were observed in midden units. Middens were excavated at 18 sites: $41 B X 883$, 41BX890, 41BX891, 41BX892, 41BX895, 41BX896, 41BX897, 41BX900, 41BX926, 41BX927, 41BX928, 41BX929, 41BX930, 41BX931, 41BX932, 41BX937, $41 B \times 942$, and 41BX945.

\section{Analysis of Adjusted Residuals}

Tomka (1993:20) suggests that adjusted residuals "offer a way to identify more accurately the under or over-representation of particular artifact categories." General statements about the relative under or overrepresentation of artifacts can also be deduced from adjusted residuals data as Haberman (1978:79) suggests that values "provide a rough indication of the size of errors." Adjusted residuals by depositional type were calculated for artifact counts for all Alamodome sites combined (Table 6-4), and individually for the two sites (41BX896 and 41BX945) where all seven depositional types were excavated (Tables 6-5 and 6-6). Table 6-4 shows that at the 0.05 level of significance ( 5 percent standard normal deviate $=1.96$ [Everitt 1977:47]), 77.6 percent of the cells for the combined sites had significant variability. Forty-five percent of the cells at 41BX896 (Table 6-5) and 57.1 percent of the cells at $41 B \times 945$ had significant variation (Table 6-6). This data is summarized in Figures 6-1, 6-2, and 6-3 (the 1.96 standard normal deviate-both positive and negative-is represented by dashed lines). Some of the observed differences in artifact distributions may be explained by formation and behavioral processes and are explored below.

\section{Identification of Formation Processes}

When data from all the sites were combined (Figure 6-1 and Table 6-4), clothing, personal, and activityrelated artifacts were recovered in greater-than- 
Table 6-4. Adjusted Residuals by Artifact Group and Depositional Type for All Excavated Alamodome Sites (Combined)

\begin{tabular}{lccccccc}
\hline & kitchen & bone & furnishings & clothing & personal & activities & arms \\
beneath dwelling & 2.5 & $-\mathbf{1 0 . 2}$ & -0.87 & $\mathbf{3 . 3 7}$ & $\mathbf{6 . 7 1}$ & $\mathbf{1 0 . 7 1}$ & $\mathbf{2 . 8}$ \\
dwelling foundations & -0.63 & $\mathbf{- 2 . 3 9}$ & -0.11 & $\mathbf{2 . 6 6}$ & $\mathbf{4 . 9 1}$ & $\mathbf{3 . 0 8}$ & -1.01 \\
$\mathbf{2}$ m adj. dwelling & 1.66 & $\mathbf{- 9 . 3 8}$ & $\mathbf{- 2 . 4 8}$ & $\mathbf{3 . 9 1}$ & $\mathbf{8 . 2 7}$ & $\mathbf{1 1 . 3 9}$ & 1.25 \\
outbuilding & $\mathbf{2 4 . 6 9}$ & $\mathbf{- 3 1 . 5 7}$ & $\mathbf{- 8 . 5 6}$ & $\mathbf{1 4 . 9 1}$ & 0.98 & $\mathbf{9 . 3 6}$ & $\mathbf{- 2 . 3 7}$ \\
$\mathbf{2}$ m adj. outbldg. & $\mathbf{2 . 6 3}$ & $\mathbf{- 5 . 1 8}$ & $\mathbf{- 5 . 0 8}$ & $\mathbf{3 . 5 9}$ & 1.01 & $\mathbf{5 . 9 1}$ & 0.09 \\
yard areas & $\mathbf{1 0 . 0 2}$ & $\mathbf{- 3 . 1 7}$ & $\mathbf{- 1 6 . 4 5}$ & $\mathbf{- 5 . 6 2}$ & 0.63 & 0.5 & $\mathbf{- 4 . 9 8}$ \\
\hline
\end{tabular}

Table 6-5. Adjusted Residuals by Artifact Group and Depositional Type, $41 \mathrm{BX} 896$

\begin{tabular}{lccccccc}
\hline & kitchen & bone & furnishings & clothing & personal & activities & arms \\
beneath dwelling & -4.9 & 2.34 & -1.9 & 1.13 & 3.9 & 3.9 & 0.17 \\
dwelling foundations & -0.65 & 0.3 & -0.33 & -0.4 & -0.25 & 1.37 & -0.09 \\
$\mathbf{2}$ m adj. dwelling & -2.77 & -0.01 & $\mathbf{3 . 2 1}$ & $-\mathbf{2 . 4 8}$ & 0.64 & $\mathbf{4 . 5 9}$ & 0.48 \\
outbuilding & $\mathbf{2 4 . 6 7}$ & $-\mathbf{- 2 5 . 0 7}$ & $\mathbf{- 7 . 1 9}$ & $\mathbf{3 . 5 3}$ & $\mathbf{- 3 . 4 1}$ & $\mathbf{- 3 . 8 5}$ & 0.23 \\
$\mathbf{2} \mathrm{m}$ adj. outbldg. & -0.72 & 1.76 & -0.8 & 0.07 & 1.07 & -1.37 & -0.22 \\
\hline
\end{tabular}

Table 6-6. Adjusted Residuals by Artifact Group and Depositional Type, 41 BX945

\begin{tabular}{lccccccc}
\hline & kitchen & bone & furnishings & clothing & personal & activities & arms \\
beneath dwelling & $\mathbf{2 2 . 8 3}$ & $\mathbf{- 3 2 . 2 9}$ & $\mathbf{5 . 6 9}$ & 1.14 & $\mathbf{7 . 4 9}$ & $\mathbf{1 4 . 8 9}$ & $\mathbf{8 . 9 6}$ \\
dwelling foundations & $\mathbf{6 . 8 7}$ & $\mathbf{- 8 . 9 8}$ & $\mathbf{2 . 7 4}$ & -0.98 & 1.07 & $\mathbf{3 . 9 3}$ & -0.43 \\
$\mathbf{2}$ m adj. dwelling & $\mathbf{1 0 . 7}$ & $\mathbf{- 1 0 . 6 7}$ & -1.37 & -1.05 & -0.65 & 1.88 & -0.47 \\
outbuilding & $\mathbf{9 . 7 8}$ & $\mathbf{- 1 0 . 0 1}$ & $\mathbf{0 . 1 9}$ & -0.8 & -0.92 & $\mathbf{2 . 3 4}$ & -0.66 \\
$\mathbf{2}$ m adj. outbldg. & $\mathbf{2 . 7 1}$ & $\mathbf{- 4 . 9 8}$ & -1.73 & 0.21 & 1.65 & $\mathbf{5 . 6 6}$ & 1.13 \\
yard areas & $\mathbf{2 2 . 9 1}$ & $\mathbf{- 2 5 . 1}$ & -1.26 & -1.34 & $\mathbf{2 . 4 4}$ & $\mathbf{8 . 2 2}$ & -0.12 \\
\hline
\end{tabular}




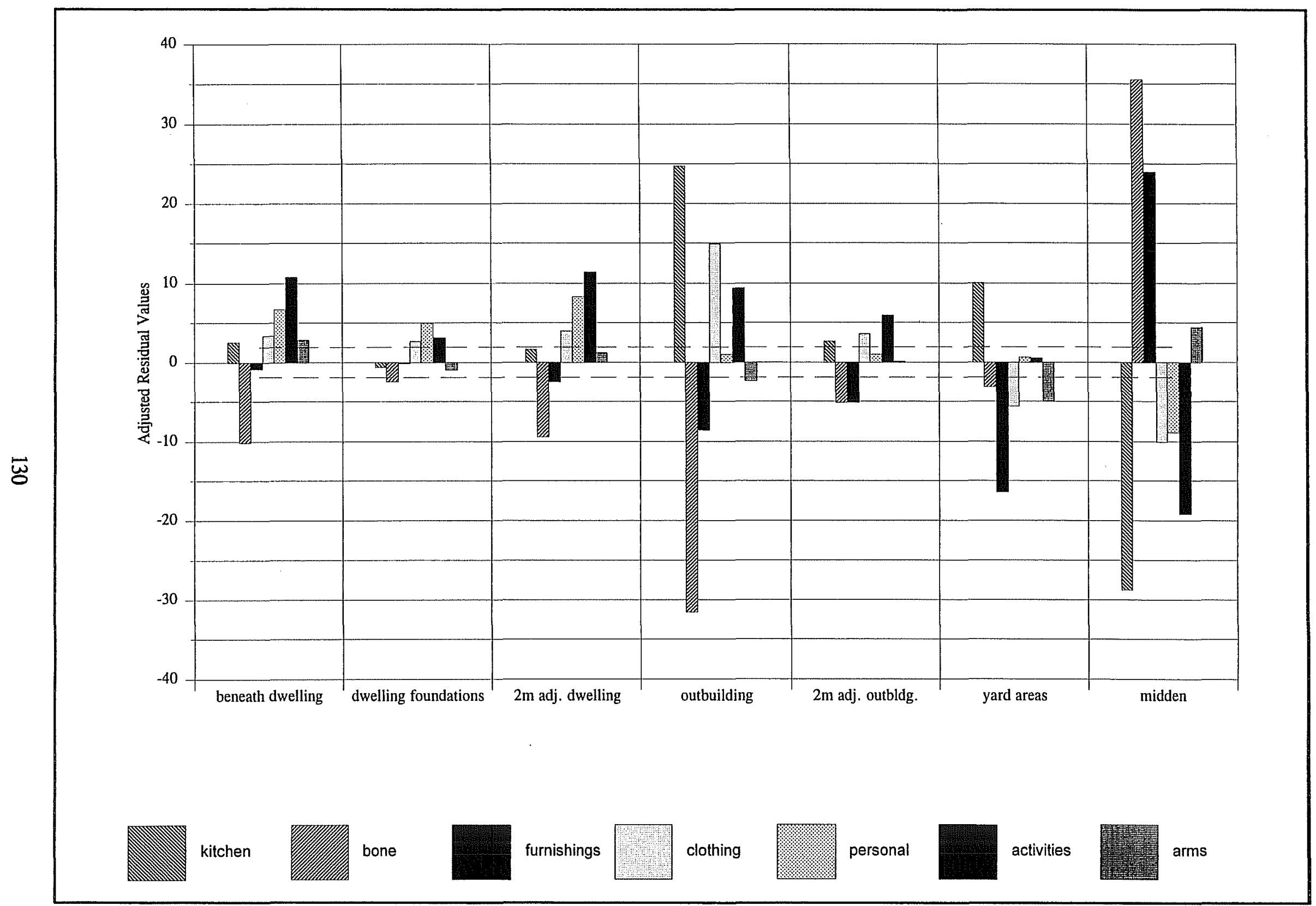

Figure 6-1. Adjusted residual values for combined sites. 


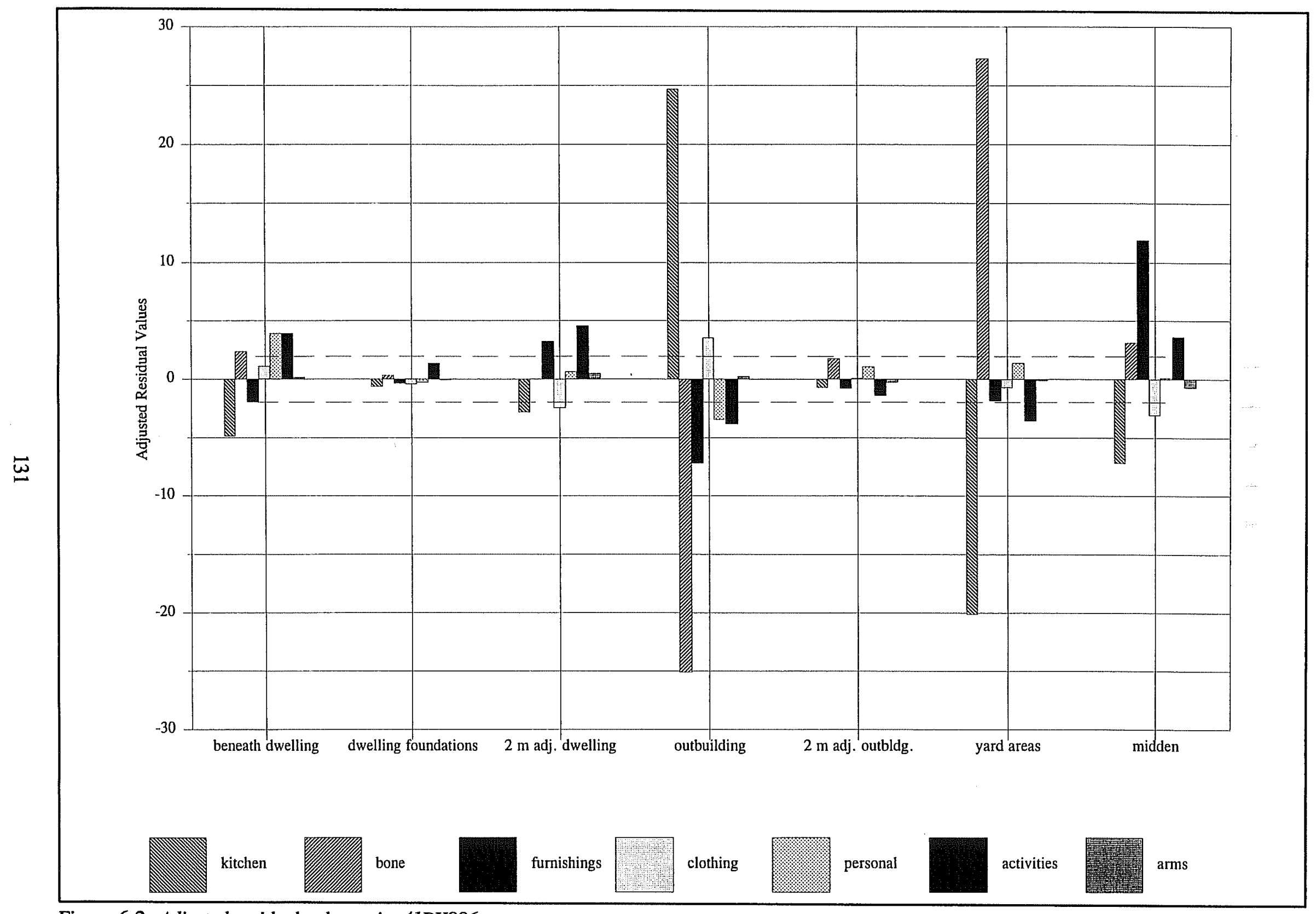

Figure 6-2. Adjusted residual values, site 41BX896. 


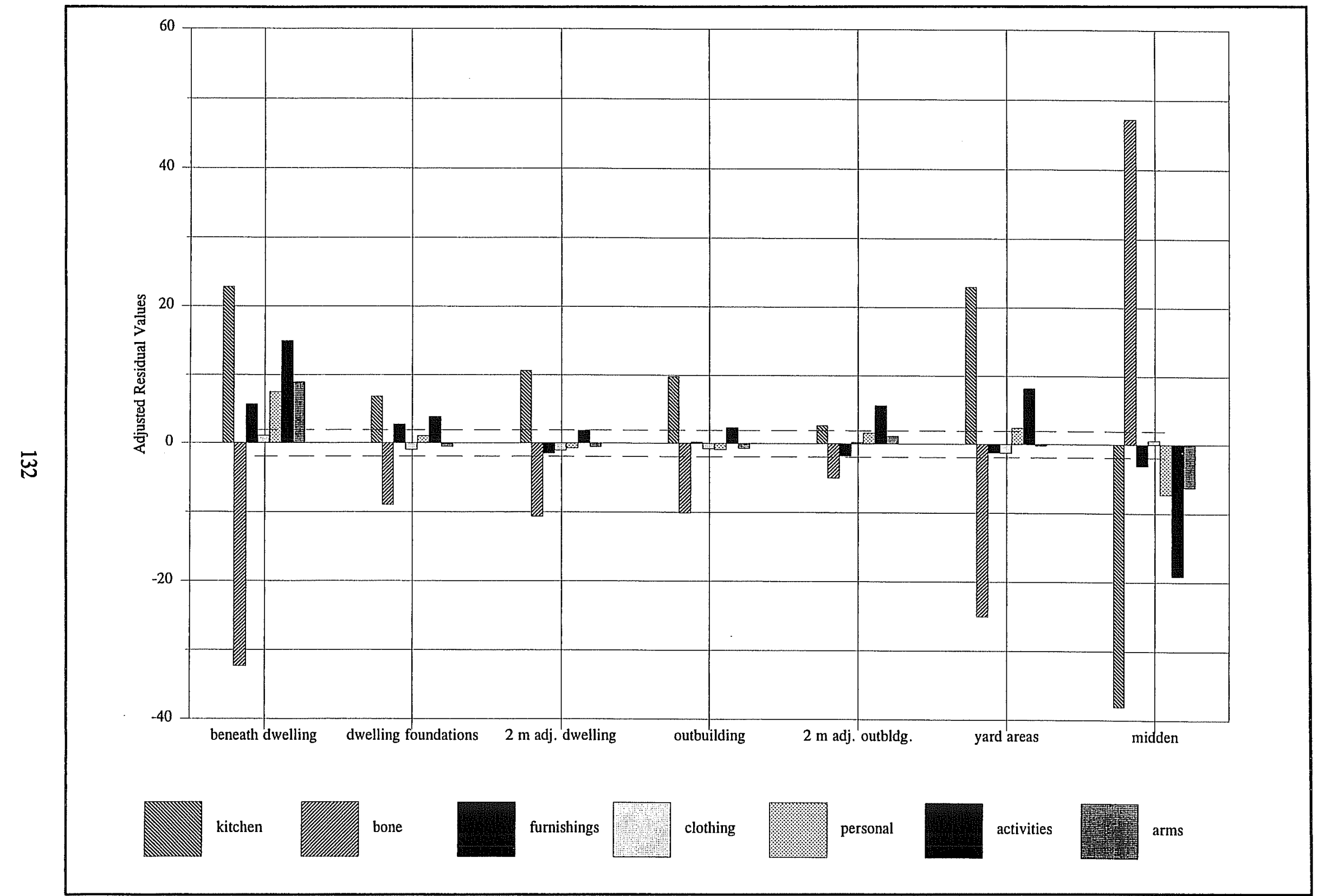

Figure 6-3. Adjusted residual values, site $41 B \times 945$. 
expected quantities in units excavated in or around the primary dwelling (beneath primary dwelling, primary dwelling foundations, and two meters adjacent to primary dwelling), while bone was recovered in lessthan-expected quantities in the same units. The clothing, personal, and activity-related artifact groups contained a number of small, frequently occurring items such as beads, buttons, coins, jewelry, doll parts, and marbles. Archaeologists such as Schiffer (1983:679, 1987:77) suggest that small items-like those recovered in or near Alamodome area dwellings-are more likely to be lost than large items. Animal bone and furnishing artifacts, however, were probably intentionally discarded (in areas away from the dwelling). Much greater-than-expected quantities of both animal bone (35.57) and furnishings (23.91) were, in fact, recovered from middens. Similar patterns in and around outbuildings were observed (greater-than-expected quantities of kitchen, clothing, activity-related artifacts; but less-than-expected quantities of animal bone and furnishings) and can also be explained by the same processes of loss and intentional discard.

At 41BX896 (Figure 6-2), bone and kitchen artifacts, in general, were inversely distributed. However, their distribution in certain depositional types varied considerably from the combined sites data. In units excavated beneath the primary dwelling, less-thanexpected quantities of kitchen artifacts $(-4.9)$ were recovered and greater-than-expected amounts of animal bone (2.34) were recovered. Perhaps these differences exist because only at the Demazieres site were units excavated beneath a standing structure. The significantly less-than-expected number of kitchen artifacts $(-20.09)$ and the more-than-expected amounts of bone (27.28) in yard areas may be related to the site's changing boundaries and is explained below.

As Figure 6-3 reveals, the deviation from the expected quantities for all artifact groups except clothing from units excavated from beneath the primary dwelling are more severe at 41BX945 than for the combined sites. This may be because $41 \mathrm{BX} 945$ contained the only excavated basement. All material left in the house when it was abandoned was probably used as fill for the basement when the house was razed. At other sites where the houses had been destroyed (but did not have basements), a majority of the debris was probably moved off the site.
Beginning in the $1840 \mathrm{~s}$, San Antonio also began regulating trash disposal and removal to prevent the spread of disease (City Ordinance [CO], City Secretary's Office, City Hall, San Antonio, Texas, JA-224:104, May 18, 1844, JA-291:118, April 4, 1846). Regulations were changed and improved periodically in response to specific public health threats. For instance, in 1867, to prevent the transmission of cholera, residents were required to deposit garbage in barrels three times a week so that trash could be carried to outside the city limits. The ordinance also provided standards for the cleaning and maintenance of "yards, streets, kitchens, and dwellings" (CO OI-199:330, November 25, 1867).

The continuing problem of disease eventually forced the city to create a Board of Health in 1883 (CO OA$56: 81$, September 4,1883 ). Four police officers, one for each ward of the city, were declared health and sanitary inspectors and were made responsible for the enforcement of health ordinances. Inspectors were directed to locate and cite public health nuisances on both public and private land in their jurisdiction. An extensive list of violations was created. "The filling, leveling or raising the surface of any street, ground or lot within the city with animal or vegetable substances, filth [excrement] gathered in cleaning yards and streets" was specifically prohibited (CO OA-61:94, December 18,1883 ). Not surprisingly, a year after the new ordinances were passed, the city had to hire additional garbage collectors (CO JF-88:126, July 14, 1884).

A number of records from the 1890 s document expenses for leasing land outside the city for garbage dumps and incinerators (CO JJ-255:243, September 19, 1892; CO JJ-409:334, December 5, 1892; CO JJ633:498, April 3, 1893). As late as 1918, the city passed an ordinance regulating the placement of and collection from trash cans (CO OF-68:295, January 24, 1918).

The less-than-expected quantities of bone $(-3.17)$, furnishings (-16.45), clothing (-5.62), and arms (-4.98) recovered from yard areas may suggest that yards in the project area were kept reasonably refuse free (relative to the other depositional types). Plus, the statistical overrepresentation of bone (35.57) only in midden units (typically abandoned privies and wells) seems to suggest that families, at the very least, attempted to bury or hide bones. 
Changing site and lot boundaries over time may have affected deposits in multiple ways. When compared with the data from the combined Alamodome sites and 41BX945, midden units (a privy) at 41BX896 (Table 6-5 and Figure 6-2) had relatively less bone than expected, while units excavated in yard areas had relatively more bone than expected. [Bone was collected in greater-than-expected quantities in middens and less-than-expected quantities in yard units at $41 \mathrm{BX} 896$, but not at the same magnitudes as at the combined sites or at $41 \mathrm{BX} 945$. Thus, the relative statements about the occurrence of bone in yard areas and in middens.] At the time that the privy was filledca. 1910 (see Brown and DeLaO, Volume III)residents living at $41 \mathrm{BX} 896$ probably did not have access to the privy and, consequently, deposited more bone in the yard. The lot that 41BX896 occupied was subdivided and a rental house was constructed at 110 Nebraska (110 Martin Luther King) around 1906-1907 on the portion of the lot occupied by the privy. It seems likely, therefore, that changing site and lot boundaries may influence interpretations about the distribution of certain artifacts. Why the residents of 110 Nebraska did not discard their animal bones in the privy remains unanswered.

The recovery of few relatively early artifacts from Alamodome sites first occupied in ca. 1850 to 1870 may also have been influenced by changing lot boundaries. Until about the turn of the century, vacant land within the project area was available for residents to dispose of their waste. As Volume I documents, in 1850 at least 62 percent of all of the lots within the project area were undeveloped or vacant. This number declined over time to about one percent in the mid1920s. Seventeen of the 30 lots on NCB 636, which includes 41BX896, and half of the lots on NCB 615 , which includes 41BX945, were undeveloped and vacant until 1900 . Thus, with few houses to delineate clear boundaries, South's peripheral region may have been greatly expanded to include refuse areas so distant that we were unable to detect them or to connect them to the appropriate sites. Moreover, the removal of refuse would have had severe impacts on the amount of material recovered and their distribution.

Multiple occupations caused several features to be reused and filled in years after their original con- struction. Brown and DeLaO (Volume III) estimate that the privies at $41 \mathrm{BX} 896$ and $41 \mathrm{BX} 945$-both of which have been occupied since the $1850 \mathrm{~s}$-were filled around 1910. Wells and privies in San Antonio often were filled after water or sewer connections were made near the turn of the century. Fox (personal communication 1996) suggests that many wells and privies were filled when a house was abandoned (either temporarily or permanently) or demolished. The assumption that the large amounts of worn, discarded furniture found at abandoned Alamodome area sites at the time of excavation may be representative of earlier periods may help to explain the statistically greater-than-expected quantities of furnishing-related artifacts recovered in middens across all sites (Table 6-4 and Figure 6-1) and at 41BX896 (Table 6-5 and Figure 6-2).

In units excavated in or near outbuildings, extremely higher-than-expected quantities of kitchen-related artifacts and extremely lower-than-expected amounts of bone were recovered (Table 6-4). As mentioned, archival research suggests that many of the outbuildings in the project area were converted to rentals in the late-nineteenth and early twentieth centuries. Research (South 1979) has documented that regular sweeping and other cleaning activities in and around dwellings would have deposited kitchen artifacts (broken glass and broken ceramics) in areas adjacent to dwellings. Likewise, food remains (animal bone) may have been transported away from the dwelling to minimize and/or prevent pest infestations (South 1979). The patterns observed around Alamodome outbuildings may provide evidence of their later domestic function.

Previous archaeological research in San Antonio suggests that different artifact distribution patterns may exist between different classes (Anne A. Fox, personal communication 1996). It is believed that lowersocioeconomic households tend to have more extensive concentrations of sheet refuse in yard areas than middle- or upper-socioeconomic households (Labadie 1987). We wanted to test this hypothesis at the Runge Street sites, which were used throughout their history as rentals by occupants who were relatively poorer than other residents of the project area. However, not enough depositional types were excavated at these sites to detect meaningful differences between spatial units. 
For the combined Alamodome sites, less-than-expected or expected quantities of artifacts, except for kitchen artifacts, were recovered from yard units (Table 6-4).

\section{Summary}

By standardizing excavation units into spatial (or depositional) units, we were able to compare similar areas from different Alamodome sites. Analysis of the adjusted residuals data for the artifact groups by spatial units allowed us to identify inter- and intrasite artifact patterns. These patterns, in turn, allowed us to more closely examine site formation processes for the project area and at individual sites. 


\section{Chapter 7 \\ Conclusions and Recommendations}

\section{Sanborn Map Evaluation}

One goal of the Alamodome Project was to evaluate the effectiveness of Sanborn Maps. Based upon comparisons of the structures represented on the Sanborn maps that appeared to be still standing in the project area, as well as past projects where Sanborn maps had been used as supplementary reference, we were confident of a certain degree of accuracy. The sizes and shapes of most of the residences observed are accurate, as are their positions as far as location within the lots. Measurements taken using the Sanborn maps for reference could, for the most part, be expected to be accurate to within two to five feet. As expected, there were cases where attempts to find remains of a building depicted on the Sanborn map met with little success. In other cases, remnants were found in a good state of preservation and confirmation was fairly easy. Also as expected, the remains of many structures not pictured on any of the Sanborn maps were located.

In the final analysis it can be reasonably stated that what the Sanborns show, they show to a high degree of accuracy (Table 7-1). In only one case were we able to confirm a measurement error on the Sanborn maps (a 20-x-15-ft outbuilding is shown as 20-x-10-ft on the 1911 Sanborn). The Sanborns were also valuable in locating areas of lots that may have seen high activity over time. The maps also show that certain disturbed archaeological contexts result from several buildings occupying the same location over time. However, poor preservation had left intact little evidence of any individual structures.

\section{Site Types}

In general, the project area developed in four phases: Early Residential Development (1850 to 1860), Residential Growth and Early Industrial Development (1860 to 1880), Residential Climax (1880 to 1900), and Industrial Infusion (1900 to 1950). Table 7-2 summarizes the percent of each known site type (e.g., undeveloped, residential, commercial, and industrial) that was archaeologically investigated for the four developmental periods. Well over 50 percent of all of the known residential lots for the periods before 1900 were examined. Our sample size was considerably smaller for lots that were residential between 1900 and 1950; yet 36 percent of the known residential sites from that period were investigated. No lots that had been used for commercial or industrial purposes before 1880 were identified. Excavation at commercial sites was limited to the Garza Store (41BX895) and the Mendit Shop (41BX956). The seven industrial lots that we examined were originally residential sites41BX892, 41BX898, 41BX899, 41BX900, 41BX926, 41BX955, and 41BX957-that had late industrial components.

\section{Artifact Patterns}

Two major populations were identified from the data analyzed during the course of this study: 1) the south project area population (sites on and around Runge Street), and 2) the north project area population (sites located from Martin Luther King Street north). The primary factors differentiating these two populations were that the south population tended to show higher 
Table 7-1. A Comparison of Sanborn Map Structures vs.

What was Found Archaeologically during the Alamodome Project

(D-Dwelling O-Outbuildings S-Shops)

\begin{tabular}{|c|c|c|c|c|c|c|c|c|c|c|c|c|c|}
\hline 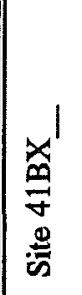 & 息 & $\vec{\rho}$ & $\stackrel{8}{2}$ & 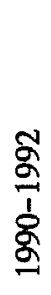 & 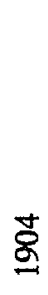 & $\bar{\sigma}$ & ู้ & 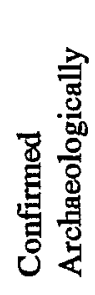 & 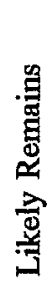 & 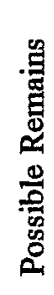 & 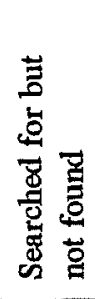 & 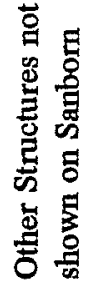 & 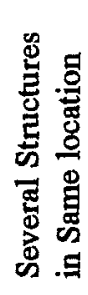 \\
\hline \multirow{3}{*}{881} & \multirow{3}{*}{621} & \multirow{3}{*}{ A11 } & $\mathrm{D}$ & 1 & 1 & 2 & 1 & 0 & 1 & 1 & 0 & 0 & no \\
\hline & & & 0 & 1 & 1 & 0 & 0 & 0 & 0 & 1 & 0 & 0 & yes \\
\hline & & & $S$ & 0 & 0 & 0 & 0 & 0 & 0 & 0 & 0 & 0 & no \\
\hline \multirow{3}{*}{882} & \multirow{3}{*}{621} & \multirow{3}{*}{$11(\mathbb{N})$} & D & 0 & 1 & 1 & 1 & 1 & 0 & 0 & 0 & 0 & no \\
\hline & & & 0 & 0 & 2 & 2 & 2 & 2 & 0 & 0 & 0 & 0 & yes \\
\hline & & & $\mathrm{S}$ & 0 & 0 & 0 & 0 & 0 & 0 & 0 & 0 & 0 & no \\
\hline \multirow{3}{*}{$\mid 883$} & \multirow{3}{*}{621} & \multirow{3}{*}{9} & $\mathrm{D}$ & 1 & 2 & 1 & 3 & 3 & 0 & 0 & 0 & 0 & yes \\
\hline & & & 0 & 0 & 1 & 4 & 3 & 2 & 1 & 0 & 0 & 1 & yes \\
\hline & & & $\mathrm{s}$ & 0 & 0 & 0 & 0 & 0 & 0 & 0 & 0 & 0 & no \\
\hline \multirow{3}{*}{884} & \multirow{3}{*}{620} & \multirow{3}{*}{12} & D & 1 & 1 & 1 & 1 & 1 & 0 & 0 & 0 & 0 & yes \\
\hline & & & 0 & 1 & 1 & 1 & 1 & 0 & 0 & 0 & 0 & 0 & yes \\
\hline & & & $\mathrm{s}$ & 0 & 0 & 0 & 0 & 0 & 0 & 0 & 0 & 0 & no \\
\hline \multirow{3}{*}{885} & \multirow{3}{*}{627} & \multirow{3}{*}{7} & D & 1 & 1 & 1 & 1 & 0 & 0 & 0 & 0 & 0 & no \\
\hline & & & 0 & 1 & 1 & 1 & 1 & 0 & 0 & 1 & 0 & 0 & yes \\
\hline & & & $\mathrm{S}$ & 1 & 0 & 0 & 1 & 0 & 0 & 0 & 0 & 0 & no \\
\hline \multirow{3}{*}{890} & \multirow{3}{*}{613} & \multirow{3}{*}{4} & D & 0 & 1 & 1 & 0 & 1 & 0 & 0 & 0 & 0 & no \\
\hline & & & 0 & 0 & 0 & 1 & 0 & 0 & 0 & 0 & 0 & 1 & no \\
\hline & & & $S$ & 0 & 0 & 0 & 0 & 0 & 0 & 0 & 0 & 0 & no \\
\hline \multirow{3}{*}{891} & \multirow{3}{*}{613} & \multirow{3}{*}{5} & D & 0 & 1 & 1 & 0 & 1 & 0 & 0 & 0 & 0 & no \\
\hline & & & 0 & 0 & 0 & 1 & 0 & 0 & 0 & 1 & 0 & 0 & no \\
\hline & & & $\mathbf{S}$ & 0 & 0 & 0 & 0 & 0 & 0 & 0 & 0 & 0 & no \\
\hline \multirow{3}{*}{892} & \multirow{3}{*}{613} & \multirow{3}{*}{6} & $\mathrm{D}$ & 0 & 1 & 1 & 0 & 1 & 0 & 0 & 0 & 0 & yes \\
\hline & & & 0 & 0 & 1 & 4 & 0 & 1 & 1 & 0 & 0 & 0 & yes \\
\hline & & & $S$ & 0 & 0 & 3 & 1 & 0 & 0 & 0 & 2 & 0 & yes \\
\hline \multirow{3}{*}{893} & & & D & 2 & 1 & 1 & 2 & 0 & 0 & 0 & 0 & 0 & no \\
\hline & 615 & 7 & 0 & 0 & 2 & 2 & 1 & 0 & 1 & 0 & 2 & 0 & yes \\
\hline & & & $\mathrm{s}$ & 0 & 0 & 0 & 0 & 0 & 0 & 0 & 0 & 0 & no \\
\hline & & & $\mathrm{D}$ & 4 & - & - & - & 0 & 0 & 0 & 0 & 0 & no \\
\hline 894 & 615 & 8 & 0 & 1 & - & - & - & 0 & 1 & 0 & 1 & 0 & no \\
\hline & & & $\mathrm{s}$ & 0 & - & - & - & 0 & 0 & 0 & 0 & 0 & no \\
\hline & & & $\mathrm{D}$ & 1 & 1 & 1 & 1 & 1 & 0 & 0 & 0 & 0 & yes \\
\hline 895 & 628 & 1,2 & 0 & 0 & 1 & 1 & 0 & 1 & 0 & 0 & 0 & 0 & no \\
\hline & & & $\mathbf{S}$ & 1 & 1 & 1 & 1 & 0 & 0 & 0 & 0 & 0 & no \\
\hline
\end{tabular}


Table 7-1. continued

(D - Dwelling O-Outbuildings S-Shops)

\begin{tabular}{|c|c|c|c|c|c|c|c|c|c|c|c|c|c|}
\hline 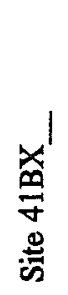 & 己 & $\ddot{\circ}$ & $\stackrel{8}{2}$ & $\begin{array}{l}\text { S } \\
\frac{1}{1} \\
\text { \& }\end{array}$ & 总 & $\bar{a}$ & 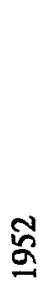 & 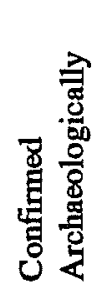 & 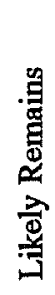 & 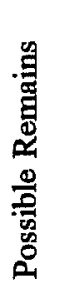 & 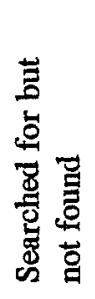 & 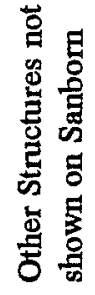 & 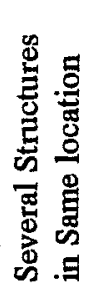 \\
\hline 896 & 636 & 4,5 & $\begin{array}{l}D \\
O \\
S\end{array}$ & $\begin{array}{l}3 \\
2 \\
0\end{array}$ & $\begin{array}{l}3 \\
6 \\
0\end{array}$ & $\begin{array}{l}3 \\
3 \\
0\end{array}$ & $\begin{array}{l}3 \\
2 \\
0\end{array}$ & $\begin{array}{l}0 \\
2 \\
0\end{array}$ & $\begin{array}{l}0 \\
1 \\
0\end{array}$ & $\begin{array}{l}0 \\
3 \\
0\end{array}$ & $\begin{array}{l}0 \\
0 \\
0\end{array}$ & $\begin{array}{l}0 \\
3 \\
0\end{array}$ & $\begin{array}{c}\text { yes } \\
\text { yes } \\
\text { no }\end{array}$ \\
\hline 897 & 621 & 7 & $\begin{array}{l}D \\
O \\
S\end{array}$ & $\begin{array}{l}0 \\
0 \\
0\end{array}$ & $\begin{array}{l}2 \\
3 \\
0\end{array}$ & $\begin{array}{l}2 \\
6 \\
0\end{array}$ & $\begin{array}{l}2 \\
2 \\
0\end{array}$ & $\begin{array}{l}2 \\
0 \\
0\end{array}$ & $\begin{array}{l}0 \\
3 \\
0\end{array}$ & $\begin{array}{l}0 \\
0 \\
0\end{array}$ & $\begin{array}{l}0 \\
0 \\
0\end{array}$ & $\begin{array}{l}1 \\
1 \\
0\end{array}$ & $\begin{array}{l}\text { yes } \\
\text { yes } \\
\text { no }\end{array}$ \\
\hline 898 & 622 & 9,10 & $\begin{array}{l}D \\
0 \\
S\end{array}$ & $\begin{array}{l}0 \\
0 \\
0\end{array}$ & $\begin{array}{l}1 \\
2 \\
0\end{array}$ & $\begin{array}{l}1 \\
3 \\
0\end{array}$ & $\begin{array}{l}1 \\
1 \\
0\end{array}$ & $\begin{array}{l}2 \\
0 \\
0\end{array}$ & $\begin{array}{l}0 \\
0 \\
0\end{array}$ & $\begin{array}{l}0 \\
1 \\
0 \\
\end{array}$ & $\begin{array}{l}0 \\
0 \\
0 \\
\end{array}$ & $\begin{array}{l}0 \\
0 \\
0 \\
\end{array}$ & $\begin{array}{c}\text { yes } \\
\text { yes } \\
\text { no }\end{array}$ \\
\hline 899 & 622 & 8 & $\begin{array}{l}D \\
O \\
S\end{array}$ & $\begin{array}{l}0 \\
0 \\
0\end{array}$ & $\begin{array}{l}1 \\
2 \\
0\end{array}$ & $\begin{array}{l}1 \\
3 \\
0\end{array}$ & $\begin{array}{l}0 \\
0 \\
0\end{array}$ & $\begin{array}{l}1 \\
0 \\
0\end{array}$ & $\begin{array}{l}0 \\
0 \\
0\end{array}$ & $\begin{array}{l}0 \\
0 \\
0\end{array}$ & $\begin{array}{l}0 \\
0 \\
0\end{array}$ & $\begin{array}{l}0 \\
0 \\
0\end{array}$ & $\begin{array}{l}\text { no } \\
\text { no } \\
\text { no }\end{array}$ \\
\hline 900 & 622 & 6 & $\begin{array}{l}\mathrm{D} \\
\mathrm{O} \\
\mathrm{S}\end{array}$ & $\begin{array}{l}0 \\
0 \\
0 \\
\end{array}$ & $\begin{array}{l}2 \\
0 \\
0 \\
\end{array}$ & $\begin{array}{l}3 \\
0 \\
0\end{array}$ & $\begin{array}{l}0 \\
0 \\
0 \\
\end{array}$ & $\begin{array}{l}3 \\
0 \\
0 \\
\end{array}$ & $\begin{array}{l}0 \\
0 \\
0 \\
\end{array}$ & $\begin{array}{l}0 \\
0 \\
0 \\
\end{array}$ & $\begin{array}{l}0 \\
0 \\
0 \\
\end{array}$ & $\begin{array}{l}0 \\
0 \\
0 \\
\end{array}$ & $\begin{array}{l}\text { no } \\
\text { no } \\
\text { no } \\
\end{array}$ \\
\hline 927 & 613 & 11,16 & $\begin{array}{l}D \\
O \\
S\end{array}$ & $\begin{array}{l}0 \\
0 \\
0\end{array}$ & $\begin{array}{l}1 \\
1 \\
0\end{array}$ & $\begin{array}{l}1 \\
0 \\
0\end{array}$ & $\begin{array}{l}0 \\
0 \\
1\end{array}$ & $\begin{array}{l}0 \\
1 \\
0\end{array}$ & $\begin{array}{l}0 \\
0 \\
0\end{array}$ & $\begin{array}{l}1 \\
0 \\
0\end{array}$ & $\begin{array}{l}0 \\
0 \\
0\end{array}$ & $\begin{array}{l}0 \\
0 \\
0\end{array}$ & $\begin{array}{l}\text { no } \\
\text { no } \\
\text { no }\end{array}$ \\
\hline 930 & 621 & 1 & $\begin{array}{l}D \\
O \\
S\end{array}$ & $\begin{array}{l}0 \\
0 \\
0\end{array}$ & $\begin{array}{l}- \\
- \\
-\end{array}$ & $\begin{array}{l}- \\
- \\
-\end{array}$ & $\begin{array}{l}- \\
- \\
-\end{array}$ & $\begin{array}{l}0 \\
0 \\
0\end{array}$ & $\begin{array}{l}0 \\
0 \\
0\end{array}$ & $\begin{array}{l}0 \\
0 \\
0\end{array}$ & $\begin{array}{l}0 \\
0 \\
0 \\
\end{array}$ & $\begin{array}{l}0 \\
0 \\
0\end{array}$ & $\begin{array}{l}\text { no } \\
\text { no } \\
\text { no } \\
\end{array}$ \\
\hline 936 & 636 & $\mathrm{H}, \mathrm{I}$ & $\begin{array}{l}\mathrm{D} \\
\mathrm{O} \\
\mathrm{S}\end{array}$ & $\begin{array}{l}0 \\
1 \\
0\end{array}$ & $\begin{array}{l}0 \\
0 \\
0\end{array}$ & $\begin{array}{l}0 \\
0 \\
0\end{array}$ & $\begin{array}{l}1 \\
1 \\
0\end{array}$ & $\begin{array}{l}1 \\
0 \\
0\end{array}$ & $\begin{array}{l}0 \\
0 \\
0\end{array}$ & $\begin{array}{l}0 \\
0 \\
0\end{array}$ & $\begin{array}{l}0 \\
0 \\
0\end{array}$ & $\begin{array}{l}0 \\
1 \\
0\end{array}$ & $\begin{array}{c}\text { no } \\
\text { yes } \\
\text { no }\end{array}$ \\
\hline 937 & 636 & A8 & $\begin{array}{l}\mathrm{D} \\
\mathrm{O} \\
\mathrm{S}\end{array}$ & $\begin{array}{l}2 \\
1 \\
0\end{array}$ & $\begin{array}{l}1 \\
1 \\
0 \\
\end{array}$ & $\begin{array}{l}1 \\
1 \\
0\end{array}$ & $\begin{array}{l}2 \\
3 \\
0 \\
\end{array}$ & $\begin{array}{l}0 \\
0 \\
0 \\
\end{array}$ & $\begin{array}{l}0 \\
1 \\
0\end{array}$ & $\begin{array}{l}0 \\
0 \\
0 \\
\end{array}$ & $\begin{array}{l}0 \\
0 \\
0 \\
\end{array}$ & $\begin{array}{l}0 \\
0 \\
0\end{array}$ & $\begin{array}{l}\text { no } \\
\text { no } \\
\text { no }\end{array}$ \\
\hline 938 & 636 & 7 & $\begin{array}{l}D \\
O \\
S\end{array}$ & $\begin{array}{l}2 \\
0 \\
0\end{array}$ & $\begin{array}{l}1 \\
2 \\
0\end{array}$ & $\begin{array}{l}1 \\
2 \\
0\end{array}$ & $\begin{array}{l}2 \\
1 \\
0\end{array}$ & $\begin{array}{l}0 \\
2 \\
0\end{array}$ & $\begin{array}{l}0 \\
0 \\
0\end{array}$ & $\begin{array}{l}0 \\
0 \\
0\end{array}$ & $\begin{array}{l}0 \\
0 \\
0\end{array}$ & $\begin{array}{l}0 \\
0 \\
0\end{array}$ & $\begin{array}{l}\text { no } \\
\text { no } \\
\text { no }\end{array}$ \\
\hline 939 & 636 & $\mathrm{~N}$ & $\begin{array}{l}\mathrm{D} \\
\mathrm{O} \\
\mathrm{S}\end{array}$ & $\begin{array}{l}1 \\
1 \\
0\end{array}$ & $\begin{array}{l}0 \\
0 \\
0\end{array}$ & $\begin{array}{l}0 \\
0 \\
0\end{array}$ & $\begin{array}{l}1 \\
1 \\
0\end{array}$ & $\begin{array}{l}0 \\
0 \\
0\end{array}$ & $\begin{array}{l}0 \\
0 \\
0\end{array}$ & $\begin{array}{l}0 \\
0 \\
0\end{array}$ & $\begin{array}{l}0 \\
0 \\
0\end{array}$ & $\begin{array}{l}0 \\
0 \\
0\end{array}$ & $\begin{array}{l}\text { no } \\
\text { no } \\
\text { no }\end{array}$ \\
\hline
\end{tabular}


Table 7-1. continued

(D-Dwelling $\mathrm{O}$-Outbuildings $\mathrm{S}$ - Shops)

\begin{tabular}{|c|c|c|c|c|c|c|c|c|c|c|c|c|c|}
\hline 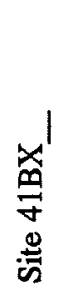 & 离 & $\ddot{\varrho}$ & $\stackrel{2}{2}$ & 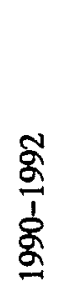 & 苍 & $\overline{\bar{a}}$ & బิ & 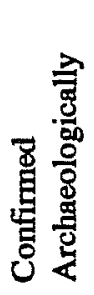 & 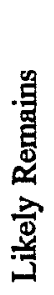 & 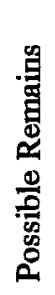 & 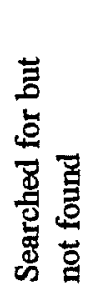 & 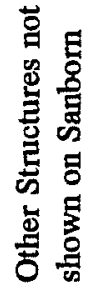 & 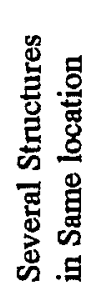 \\
\hline 941 & 636 & L & $\begin{array}{l}D \\
O \\
S\end{array}$ & $\begin{array}{l}0 \\
0 \\
0\end{array}$ & $\begin{array}{l}0 \\
0 \\
0\end{array}$ & $\begin{array}{l}0 \\
0 \\
0\end{array}$ & $\begin{array}{l}1 \\
0 \\
0\end{array}$ & $\begin{array}{l}1 \\
0 \\
0\end{array}$ & $\begin{array}{l}0 \\
0 \\
0\end{array}$ & $\begin{array}{l}0 \\
0 \\
0\end{array}$ & $\begin{array}{l}0 \\
0 \\
0\end{array}$ & $\begin{array}{l}0 \\
0 \\
0\end{array}$ & $\begin{array}{l}\text { no } \\
\text { no } \\
\text { no }\end{array}$ \\
\hline 942 & 636 & $\mathbf{J}$ & $\begin{array}{l}D \\
O \\
S\end{array}$ & $\begin{array}{l}0 \\
0 \\
0\end{array}$ & $\begin{array}{l}0 \\
0 \\
0\end{array}$ & $\begin{array}{l}0 \\
0 \\
0\end{array}$ & $\begin{array}{l}1 \\
1 \\
0\end{array}$ & $\begin{array}{l}0 \\
0 \\
0\end{array}$ & $\begin{array}{l}0 \\
0 \\
0\end{array}$ & $\begin{array}{l}0 \\
0 \\
0\end{array}$ & $\begin{array}{l}0 \\
0 \\
0\end{array}$ & $\begin{array}{l}0 \\
0 \\
0\end{array}$ & $\begin{array}{l}\text { no } \\
\text { no } \\
\text { no }\end{array}$ \\
\hline 945 & 615 & 15,16 & $\begin{array}{l}\mathrm{D} \\
\mathrm{O} \\
\mathrm{S}\end{array}$ & $\begin{array}{l}1 \\
1 \\
0\end{array}$ & $\begin{array}{l}1 \\
4 \\
0\end{array}$ & $\begin{array}{l}1 \\
3 \\
0\end{array}$ & $\begin{array}{l}1 \\
2 \\
0\end{array}$ & $\begin{array}{l}1 \\
3 \\
0\end{array}$ & $\begin{array}{l}0 \\
2 \\
0\end{array}$ & $\begin{array}{l}0 \\
1 \\
0\end{array}$ & $\begin{array}{l}0 \\
0 \\
0\end{array}$ & $\begin{array}{l}0 \\
0 \\
0\end{array}$ & $\begin{array}{l}\text { no } \\
\text { yes } \\
\text { no }\end{array}$ \\
\hline
\end{tabular}

Table 7-2. Site Types

\begin{tabular}{||c|c|c|c|c|c|c|c|c||}
\hline \multirow{2}{*}{ Dates } & \multicolumn{2}{|c|}{ Undeveloped } & \multicolumn{2}{c|}{ Residential } & \multicolumn{2}{c|}{ Commercial } & \multicolumn{2}{|c|}{ Industrial } \\
\cline { 2 - 9 } & Total & Tested & Total & Tested & Total & Tested & Total & Tested \\
\hline-1859 & 296 & 69 & 21 & 20 & 0 & 0 & 0 & 0 \\
\hline $1860-1879$ & 556 & 116 & 72 & 63 & 0 & 0 & 0 & 0 \\
\hline $1880-1899$ & 372 & 59 & 189 & 116 & 5 & 4 & 6 & 2 \\
\hline $1900-$ & 157 & 33 & 1012 & 369 & 36 & 28 & 627 & 23 \\
\hline
\end{tabular}

mean levels of kitchen items (south - 38.99 percent, north - 29.09 percent), and lower mean percentages of bone group (south - 7.49 percent, north - 18.41 percent).

A comparison between these two artifact patterns and a modified version of South's (1977) Carolina and Frontier artifact patterns is shown in Table 7-3. South did not include bone percentages in his original work, stating that bone requires special analysis and is not the same kind of by-product as the other groups (South 1977:97). Mansberger (1987) used a similar argument stating that a bone's differential preservation characteristics from site to site necessitate its placement into his "other" group. This author disagrees.

It is accepted that bone has varying degrees of preservation and different mechanisms of entry into the archeological record; however, so do many classes of artifacts within other groups. Many of the buttons that adorned clothing for hundreds of years were made of bone; are we to eliminate the clothing group because bone buttons may not have preserved well in archeological context? Undoubtedly many wood and metal items deteriorate to the point where they are not recognizable 
Table 7-3. Mean Percentage Comparison:

Alamodome Patterns Compared with South's (1977) Carolina and Frontier Patterns

\begin{tabular}{|c|c|c|c|c|}
\hline & $\begin{array}{l}\text { Alamodome } \\
\text { North }\end{array}$ & $\begin{array}{l}\text { Alamodome } \\
\text { South }\end{array}$ & $\begin{array}{c}\text { South } \\
\text { Carolina* }\end{array}$ & Frontier* \\
\hline Activity & 7.49 & 6.86 & 9.11 & 10.34 \\
\hline Architecture & 41.05 & 43.25 & 23.00 & 35.56 \\
\hline Arms & 0.12 & 0.01 & 0.69 & 1.30 \\
\hline Bone & 18.40 & 7.48 & 20.52 & 20.68 \\
\hline Clothing & 1.24 & 1.09 & 3.21 & 0.48 \\
\hline Furniture & 1.06 & 0.85 & 0.20 & 0.17 \\
\hline Kitchen & 29.09 & 48.99 & 43.07 & 31.36 \\
\hline Personal & 0.78 & 0.74 & 0.14 & 0.06 \\
\hline
\end{tabular}

within the archeological context, yet we still count furniture, architectural, and activity group items. Much of the bone on these 4-5 urban sites was present due to either direct or indirect human activity; with careful consideration it can be treated quantitatively as are many of the other groups. This project demonstrates that in some cases, bone content and frequency are the primary variables differentiating one site from another. Although the south project area population displays a lower bone percentage than the north project area, both percentages are still significantly higher than those reported from Jurney and Moir's (1987) Richland Creek excavations, and from Utley et al.'s (1990) Tidwell Prairie excavations.

Some argue that due to the fragmentary nature of bone, it is of limited value in a frequency study. This is a problem encountered not just with bone, but with other classes of artifacts such as bottle glass and ceramics. In these cases the archeologist should be concerned with the way in which these artifacts come out of the ground. The degree of fragmentation of these types of artifacts can produce important information about site formation dynamics on the site under study. In cases where much of the bone (glass, ceramic sherds, etc.) was likely to have come from one source, this should be taken into consideration and appropriate action taken to address the problem.

In the case of South's (1977) Carolina and Frontier artifact patterns, the original data was refigured including the bone percentages within the overall site samples, these modified percentages are shown in Table 7-3. Range and variability data were not included in the figure. The modified percentages did not significantly affect any of South's observations relative to the establishment of the Carolina or Frontier patterns.

Although the mean percentages of both of the Alamodome populations showed higher levels of architecture items than South's (1977) patterns, the Alamodome samples more closely resembled the Frontier pattern than the Carolina pattern. Based on the correlation matrices which were produced from the areas sampled during the course of the project, we found that varying processes of consumer behavior were in operation between lower- and upper-income groups within the project area.

The original hypotheses concerning the use of space by the residents of the Alamodome site were all confirmed by the archaeology. Artifacts were concentrated toward 
the back of the lots, while fewer artifacts were found on the front parts. Support structures were found against the side and back boundaries of the yards, and the areas beneath pier-and-beam houses contained significant numbers of artifacts.

Artifact analysis revealed that upper-class sites tended to contain lower percentages of kitchen items and armsrelated artifacts, while the number of architecture-related artifacts tended to be slightly higher at lower-income sites. The percentage of clothing and personal items does not appear to be indicative of social class. Artifact counts alone tell little about the inhabitants of a house; however, as Volume III of this series shows, examination of individual artifacts in these groups can reveal a great deal about the inhabitants.

An examination of overall living space versus artifact group percentages from similar income groups might provide useful information. One of the major differences between the lower-and upper-income groups within the Alamodome project area was that the upper-income group simply had more overall living space. This additional space would significantly affect the deposit and formation of activity areas on an archeological site. By examination of similar income groups on varying spatial zones, this aspect could be explored. Performance of a factor analysis of the data used in the creation of the correlation matrices might show more clearly some of the causal factors for the high positive and negative correlations between several of the artifact groups in the study. 


\section{References Cited}

Andrew Perez Associates, Architects

1990 Architectural Inventory and Assessment: Multi-use Dome Stadium Site, VIA Transit Terminal Site. Interim report prepared for the Center for Archaeological Research, The University of Texas at San Antonio.

Biesele, R. L.

1987[1930] The History of German Settlement in Texas, 1831-1861. McNaughton and Gunn, Ann Arbor, Michigan.

Binford, L. R.

1978 Dimensional Analysis of Behavior and Site Structure: Learning from an Eskimo Hunting Stand. American Antiquity 43:330-361.

Black, S. L., and A. J. McGraw

1985 The Panther Creek Springs Site: Cultural Change and Continuity Within the Upper Salado Creek Watershed, South Central Texas. Archeological Survey Report, No. 100. Center for Archaeological Research, The University of Texas at San Antonio.

Breig and Associate/Architect

1979 Survey of Historic Structures/Vista Verde South. Submitted to the San Antonio Conservation Society, San Antonio.

Clark, J. W., Jr.

1989 Urban Archeology: A Culture History of a Mexican-American Barrio in Laredo, Webb County, Texas. Publications in Archeology, Report \#32. Texas State Department of Highways and Public Transportation, Austin.

Cressey, P. J., and H. F. Stephens

1982 The City-Site Approach to Urban Archaeology. In Archaeology of Urban America, The Search for Pattern and Process, edited by R. S. Dickens, Jr. pp. 41-62. Academic, New York.

E. L. Fly and Associates, Inc.

1990 Oral History Interviews: Dome Project 1990. Manuscript on file, Center for Archaeological Research, The University of Texas at San Antonio.

Everitt, B. S.

1977 The Analysis of Contingency Tables. Chapman and Hall, London.

Freuden, C. (compiler)

1990 Capitol Extension Project-Interim Document. Manuscript on file, Archeology Research Program, Southern Methodist University, Dallas.

Garrow, P. H.

1981 Investigations of Yaughan and Curiboo Plantations. Paper presented at the Annual Meeting of the Society for Historical Archeology, New Orleans. 
Goffman, E.

1959 The Presentation of Self in Everyday Life. Doubleday, Garden City, New York.

Graham, M.

1994 Mobile Farmers, An Ethnoarchaeological Approach to Settlement Organization Among the Raramuri of Northeastern Mexico. International Monographs in Prehistory, Ethnological Series 3. Ann Arbor, Michigan.

Grist, E.

1992 Machine Made and Contemporary Marbles. Collector Books, Paducah, Kentucky.

Gurcke, K.

1987 Bricks and Brickmaking: A Handbook for Historical Archeology. University of Idaho Press, Moscow.

Haberman, S. J.

1978 Analysis of Qualitative Data. Volume 1: Introductory Topics. Academic, New York.

Heitzman, R.

1980 The Cochran Ranch Site. Occasional Paper No. 16. Archeological Survey of Alberta.

Jurney, D., and R. Moir

1987 Historic Buildings, Material Culture, and People of the Prairie Margins. Richland Creek Technical Series, vol. 5. Archeological Research Program, Institute for the Study of Earth and Man, Southern Methodist University, Dallas.

Kent, S.

1984 Analyzing Activity Areas, An Ethnological Study of the Use of Space. University of New Mexico Press, Albuquerque.

1991 Excavations at a Small Verde Pueblo II Anasazi Site in Southwestern Colorado. Kiva 57(1):55-75.

Labadie, J. H.

1987 An Archaeological and Historical Assessment of the Vista Verde South Project, San Antonio, Texas. Archaeological Survey Report, No. 156. Center for Archaeological Research, The University of Texas at San Antonio.

Lewis, K. E.

1980 Archeological Patterning on the Frontier: The Functional Significance of the Carolina and Frontier Patterns. The Conference on Historical Site Archeological Papers 1980, vol. 14. Institute of Archeology and Anthropology, University of South Carolina, Columbia.

Mansberger, $\mathbf{F}$.

1987 Artifact Patterns and Socio-Economic Status in the Archeological Record. Proceedings of the Symposium on Ohio Valley Urban and Historical Archeology, vol. 5. Department of Anthropology, University of Louisville.

McLemore, D.

1980 A Place in Time: A Pictorial View of San Antonio's Past. Express-News, San Antonio.

Miller, G. L.

1991 A Revised Set of CC Index Values for Classification and Economic Scaling of English Ceramics from 1787 to 1880 . Historical Archeology, 25(1):1-25. 
Moir, R. W.

1987a Farmstead Proxemics and Intrasite Planning. In Historic Buildings, Material Culture, and People of the Prairie Margins, edited by D. Jurney and R. Moir, pp. 229-245. Richland Creek Technical Series, vol. 5. Archeological Research Program, Institute for the Study of Earth and Man, Southern Methodist University, Dallas.

1987b Refined Earthenwares and Rural Ceramic Traditions. In Historic Buildings, Material Culture, and People of the Prairie Margins, edited by D. Jurney and R. Moir, pp. 97-120. Richland Creek Technical Series, vol. 5. Archeological Research Program, Institute for the Study of Earth and Man, Southern Methodist University, Dallas.

Nightengale, B. A., A. A. Fox, and I. W. Cox

1989 Archeological and Historical Investigations at the West End of the Martin and Bowie Street Connections, San Antonio, Bexar County, Texas. Archeological Survey Report, No. 86. Center for Archaeological Research, The University of Texas at San Antonio.

Noël-Hume, I.

1969 Historical Archaeology. Alfred A. Knopf, New York.

O'Connell, J. F.

1987 Alyawara Site Structure and its Archaeological Implications. American Antiquity 52(1):74-108.

Portnoy, A. W.

1981 A Microarcheological View of Human Settlement Space and Function. In Modern Material Culture, edited by R. A. Gould and M. B. Schiffer, pp. 213-234. Academic, New York.

Randall, M. E., and D. Webb

1988 Greenbridge Guide to Marbles. Greenbridge, Sykesville, Maryland.

Rubertone, P. E.

1982 Urban Land Use and Artifact Deposition: An Archaeological Study of Change in Providence, Rhode Island. In Archaeology of Urban America, The Search for Pattern and Process, edited by R.S. Dickens, Jr., pp. 117-140. Academic, New York.

Schiffer, M. B.

1983 Toward the Identification of Formation Processes. American Antiquity 48(4):675-706.

1987 Formation Processes of the Archaeological Record. University of New Mexico Press, Albuquerque.

South, S.

1977 Method and Theory in Historical Archeology. Academic, New York.

1979 Historic Site Content, Structure, and Function. American Antiquity 44:213-237.

Steinbomer, R. A.

1983 Brickmaking in Texas (working draft). Texas Historical Commission, Austin. Copy on file at the San Antonio Conservation Society Library, San Antonio.

Taylor, A. J.

1985 Archeological Excavation of a Historic Well at Mission San Jose, Bexar County, Texas. Preliminary Report. Manuscript on file, Center for Archaeological Research, The University of Texas at San Antonio. 
Taylor, F. B, R. B. Hailey, and D. L. Richmond

1991 Soul Survey of Bexar County. Soil Conservation Service, U.S. Department of Agriculture, Washington, D.C.

Texas Parks and Wildlife Department

1968 Texas Historic Forts, Part II, McKavett. School of Architecture, The University of Texas at Austin.

Thompson, B. E., and W. L. Rathje

1982 The Milwaukee Garbage Project: Archeology of Household Solid Wastes. In Archeology of Urban America: The Search for Pattern and Process, edited by R. S. Dickens, pp. 399-461. Academic, New York.

Tomka, S. A.

1993 Site Abandonment Behavior Among Transhumant Agro-Pastoralists: The Effects of Delayed Curation on Assemblage Composition. In Abandonment of Settlements and Regions: Ethnoarchaeological and Archaeological Approaches, edited by C. M. Cameron and S. A. Tomka, pp. 11-24. Cambridge University Press, Cambridge.

Utley, D. K., A. A. Fox, and G. Mehalchick

1990 Going Down that Road: Historic Archeology in Tidwell Prairie, Robertson County, Texas. Studies in Archeology 4. Texas Archeological Research Laboratory, The University of Texas at Austin.

Wilk, R., and M. B. Schiffer

1979 The Archeology of Vacant Lots in Tucson, Arizona. American Antiquity 44:530-536.

Windes, T. C.

1987 Investigations at the Pueblo Alto Complex, Chaco Canyon, New Mexico, 1975-1979. Volume 1. Publications in Archaeology 18F, Chaco Canyon Studies. National Park Service, Santa Fe.

Yellen, J. E.

1977 Archeological Approaches to the Past: Models for Reconstructing the Past. Academic, New York.

Zimmerman, C

1932 Earnst Engel's Law of Expenditures for Food. Quarterly Journal of Economics 47:78. 


\section{Appendix A \\ Artifact Classes Constituting Major Groups}

\section{Activity Group}

Burned rock

Chert fragments

Dolls

Fishing items

Flower pot fragments

Horseshoes

Machinery

Marbles

Misc. metal items

Other barn

Other misc.

Other prehistoric

Paper

Plastic

Tools

Toys

Unidentified metal

Wire

\section{Arms Group}

Bullets

Cartridges

Gun flints

Gun parts

Musket balls

Percussion caps

\section{Bone Group}

Bone
Architecture Group

Asphalt

Brick

Concrete

Cut nails

Electrical

Gas

Hinges

Mortar

Nuts and bolts

Other construction

Plaster

Screws

Shingles

Staples

Tile

Washers

Water utilities

Window glass

Wire nails

\section{Clothing Group}

Beads

Buttons

Buckles

Hooks/fasteners

Other clothing

Sewing items

Shoe parts
Furniture Group

Furniture parts

Lamp parts

Other furniture

Other lighting

Kitchen Group

Bottles

Caps/tops

Ceramics

Glass (vessel)

Kitchenwares

Tablewares

Personal Group

Coins

Combs

Jewelry

Mirror glass

Other personal

Pens/pencils/writing

Pipes

Slates 
Appendix B

Artifact Data 
Table B-1. Artifact Group Counts

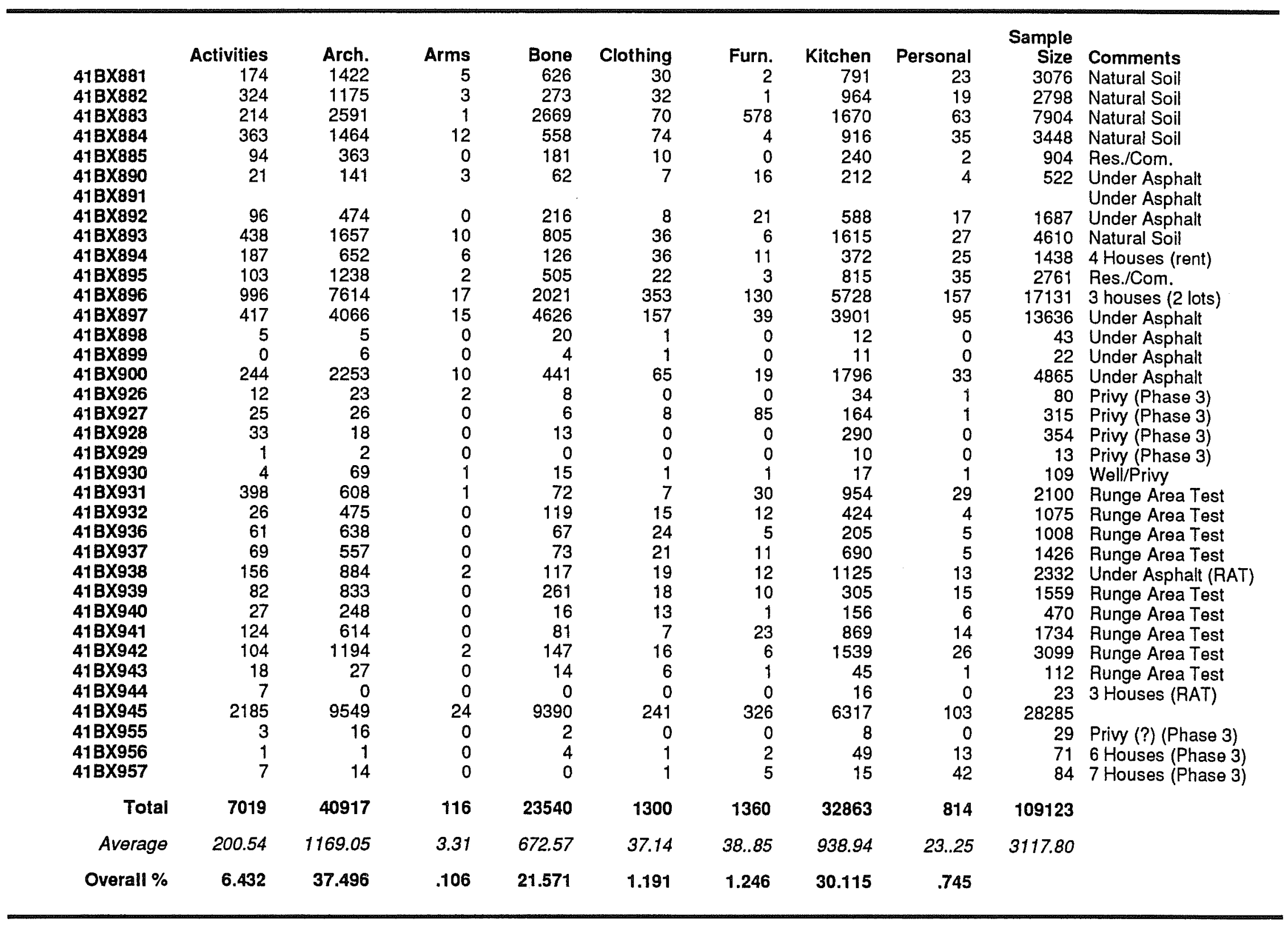


Table B-2. Artifact Group Percentages

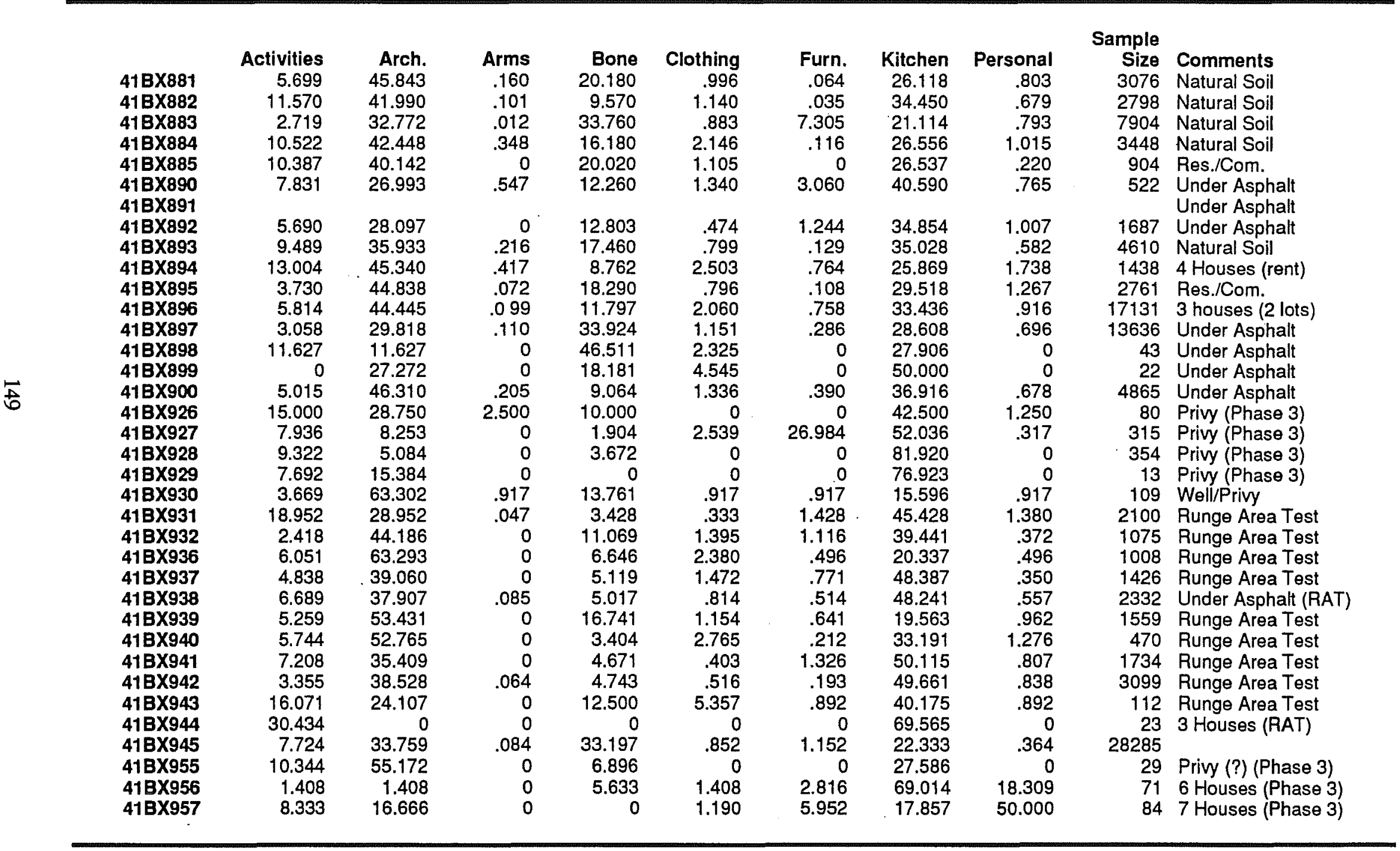


Table B-3. Artifact Frequencies: Site Rank Orders of Artifact Group Percentages

\begin{tabular}{|c|c|c|c|c|c|c|c|c|}
\hline Site \# & Act. & Arch & Arms & Bone & Cloth & Furn. & Kltch & Pers. \\
\hline $41 \mathrm{~B} \times 881$ & 13 & 4 & 6 & 4 & 13 & 20 & 17 & 10 \\
\hline $41 B \times 882$ & 3 & 10 & 8 & 14 & 11 & 21 & 10 & 14 \\
\hline $41 B \times 883$ & 21 & 18 & 15 & 2 & 14 & 1 & 20 & 11 \\
\hline $41 B \times 884$ & 4 & 9 & 3 & 9 & 3 & 18 & 15 & 4 \\
\hline $41 B \times 885$ & 5 & 11 & none & 5 & 12 & none & 16 & 22 \\
\hline $41 B \times 890$ & 7 & 22 & 1 & 11 & 7 & 2 & 6 & 13 \\
\hline $41 \mathrm{~B} \times 892$ & 14 & 21 & none & 10 & 20 & 5 & 11 & 5 \\
\hline $41 B \times 893$ & 6 & 15 & 4 & 7 & 17 & 17 & 9 & 16 \\
\hline $418 \times 894$ & 2 & 5 & 2 & 16 & 1 & 9 & 18 & 1 \\
\hline $41 B \times 895$ & 18 & 6 & 12 & 6 & 18 & 19 & 13 & 3 \\
\hline $41 B \times 896$ & 12 & 7 & 9 & 12 & 4 & 10 & 12 & 7 \\
\hline $41 \mathrm{~B} \times 897$ & 20 & 19 & 7 & 1 & 10 & 15 & 14 & 12 \\
\hline $41 \mathrm{~B} \times 900$ & 16 & 3 & 5 & 15 & 8 & 14 & 8 & 15 \\
\hline $41 \mathrm{~B} \times 931$ & 1 & 20 & 14 & 22 & 22 & 3 & 5 & 2 \\
\hline $41 \mathrm{~B} \times 932$ & 22 & 8 & none & 13 & 6 & 7 & 7 & 19 \\
\hline $41 B \times 936$ & 11 & 1 & none & 17 & 2 & 13 & 21 & 18 \\
\hline $41 \mathrm{~B} \times 937$ & 17 & 12 & none & 18 & 5 & 8 & 3 & 21 \\
\hline $41 B \times 938$ & 10 & 14 & 10 & 19 & 16 & 12 & 4 & 17 \\
\hline 41BX939 & 15 & 2 & none & 8 & 9 & 11 & 22 & 6 \\
\hline $41 B \times 941$ & 9 & 16 & none & 21 & 21 & 4 & 1 & 9 \\
\hline $41 \mathrm{~B} \times 942$ & 19 & 13 & 13 & 20 & 19 & 16 & 2 & 8 \\
\hline $41 \mathrm{~B} \times 945$ & 8 & 17 & 11 & 3 & 15 & 6 & 19 & 20 \\
\hline
\end{tabular}




\title{
Appendix C \\ Quaternary Geomorphology of the Alamodome Project Area
}

\author{
Michael B. Collins
}

A limited study of the area affected by construction of the Alamodome in downtown San Antonio was made to determine the nature of the Quaternary geomorphology and to reconnoiter for buried archaeological sites. At issue in this study was whether or not Quaternary geologic and/or archaeological evidence of significance would be destroyed by the construction project.

The Alamodome occupies a site on the east margin of the valley of the San Antonio River, approximately $1.6 \mathrm{~km}$ distance from the present river channel and $10 \mathrm{~m}$ elevation above the river. The area is fully urbanized and considerable modification of the land surface has occurred over the years, making detailed surface examination for subtle geomorphic features impossible.

Existing maps (Geologic Atlas of Texas 1974; USGS 7.5' topographic map, San Antonio East quadrangle) depict a gentle, even slope from the project area down to the margin of the present stream channel without any breaks suggestive of terracing, cut-and-fill features, levees, abandoned channels, or fluting. It is not known if the character of this slope is natural or if it has been modified. A brief pedestrian survey of the area at the initiation of this study found only disturbed land or existing pavement and structures.

The project area is mapped as an area of Houston Black Clay, a vertisol or grumusol (Boul et al. 1989; Taylor et al. 1966). This soil is described in the literature as being deep, dark gray to black, calcareous, and sometimes gravelly. It is characteristic of upland settings with calcareous substrates. This soil has an extremely high shrink-swell potential that produces internal movement driven by expansion with wetting and contraction with drying. Houston Black Clay is widely recognized for these characteristics and for vertical cracking upon desiccation (Boul et al. 1989:262). The implications of such extreme verisolic conditions for archaeology include the probable disruption of site integrity by churning movements within the soil and by the occurrence of large, open cracks down which objects may drop (cf. Duffield 1970). The usefulness of samples of this material for direct dating (cf. Collins et al. 1989) is almost totally lost because of internal churning. The very high organic content of this clay would readily yield a radiocarbon age estimate, but the meaning of the age estimate would be almost nil as the sample would undoubtedly be mixed pedogenically.

Gilgai are characteristic features of ultra-clay soils such as Houston Black Clay (Newman 1982). These are pedogenic zones of active churning, generally to depths of 1-2 $m$ below the surface, where the soil mass is slowly rolling like a thick, boiling liquid. The matrix is subjected to plastic deformation with slickensides developing along planes between adjacent masses moving past each other. In extreme cases, objects dropped at the surface can be pulled down to the base of the rotating mass in a matter of decades. Hence an archaeological feature could be totally disrupted, and spatial associations among artifacts or between artifacts and features would be completely destroyed. Damage to an archaeological site by the 
action of gilgai is documented for site 41DL184 (Peter and McGregor 1988:99-125, 256-257).

The catchment of the San Antonio River drainage above this project area only covers some $150 \mathrm{~km}^{2}$ in its present state. Given the project's distance from and height above a segment of the river with no greater catchment, it is apparent that the investigated area has not been one of active fluvial sedimentation for a long period of time. The specific question addressed in this study is whether deposits of culturally relevant age are present; if present, are they significant to human ecological inquiry; and, are cultural materials present below the surface in the deposits?

To approach these questions, six backhoe trenches were dug in widely separated locations within the project area (Figure C-1). These six trenches bear the prefix GM (for geomorphic) to distinguish them from those excavated in the project area for other purposes. The fill from each backhoe trench was removed in vertical cuts of about $25 \mathrm{~cm}$ and each cut was kept separate. All fill was scrutinized as it was removed for the presence of cultural material. A small sample (roughly 16 liters) of fill from each $25-\mathrm{cm}$ cut was screened and examined for the presence of small artifacts. Material removed from these trenches screened only with extreme effort, hence no larger volume was screened. The fill exposed by each trench was examined for its sedimentary and soil characteristics. For safety reasons, not all trenches were entered, necessitating that descriptions be based on observations from the surface and on examination of material brought up in the backhoe bucket. These data are summarized below, followed by a discussion of the findings.

Trenches GMBHT 1 and GMBHT 3 were situated near the west edge of the property and penetrate the fill nearer to the river (Figure C-1). Trenches GMBHT 2 and GMBHT 4 were located between Grape and Walnut streets, roughly midway on an east-west axis of the property (Figure C-1). This placement was designed to investigate the extent to which similarities or differences occurred along the valley cross-section.

All trenches revealed fundamentally the same subsurface conditions (Figures C-2-C-7). The ground surface at each trench location was disturbed, and subsurface evidence of Historic-period disturbance extended from 30 to $100 \mathrm{~cm}$ below surface. No intact, mature pedogenic A-horizon was observed. This disturbed surface in all trenches occurred at the top of dark gray clay which extended to depths ranging from 125 to $210 \mathrm{~cm}$ below the surface. Although the dark clay showed positive reaction to hydrochloric acid, visible carbonate was noted only in the lower part of the profile (generally greater than one meter below the surface) in the form of granules to small nodules. Below the dark clay, silty or sandy to gravelly, lightercolored fluvial deposits with advanced calcium carbonate development were encountered. No firm basis exists for determining the age of the deposits, however, some observations are relevant.

The presence of age-diagnostic artifacts would be one means of estimating the age of deposits such as these. The results of screening samples from each cut in each trench are summarized in Table C-1. No unequivocally prehistoric artifacts were recovered. The few chert pieces noted by those screening and processing this material are either naturally fractured or were broken by the power equipment used in excavating the trenches. The sparse cherty gravels at greater depth in most of the trenches account for the apparent high incidence of chert pieces in the tabulations. The other cultural objects are from the Historic period. The concentration of historic trash at and near the surface at each trench location combined with the tendency for the upper edges of the trench to crumble during excavation almost certainly accounts for the several historic artifacts (glass, metal, etc.) noted at depths greater than Level 2 (ca. $50 \mathrm{~cm}$ ) (Table C-1). Some downward movement in soil cracks or through soil shrink-swell motion might also account for some of the deeper positions of historic pieces.

Rubification and illuviation of clays are age-related pedogenic changes that can sometimes be used in inferring the age of soil (and, thereby, the deposits on which it formed), but these are not observable in Houston Black Clay. There is, however, pedogenic carbonate visible low in the dark clay and in the underlying zones. This carbonate is of moderate proportions in the dark clay but well developed in the coarser sediments below. These suggest that the clay, or at least portions of it, are Holocene in age whereas the underlying sands and gravels may well be Pleistocene in age. These are very subjective and very broad interpretations which lead to the tentative 


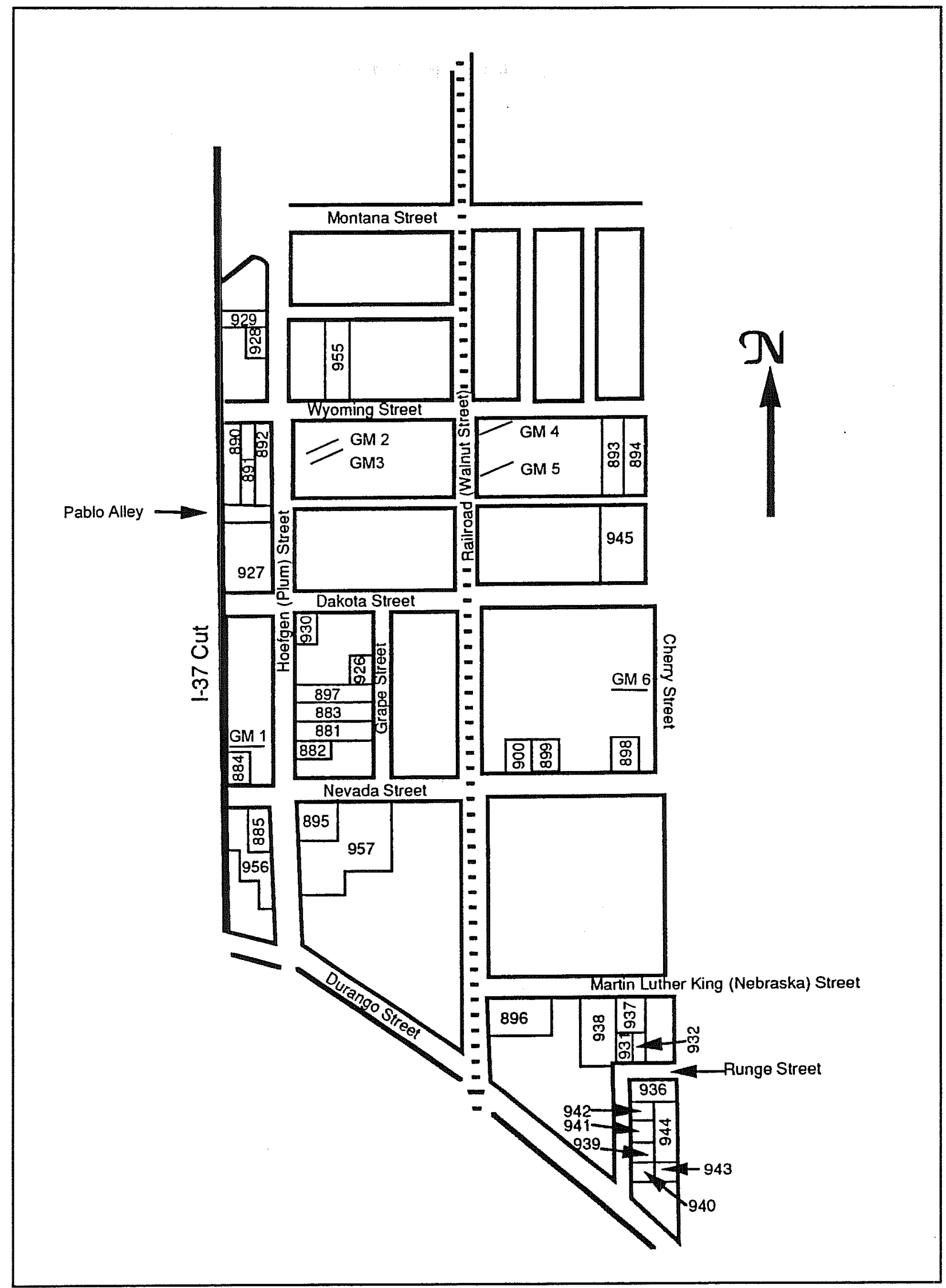

Figure C-1. Geomorphic backhoe trench (GM) locations. 
cm b.s.

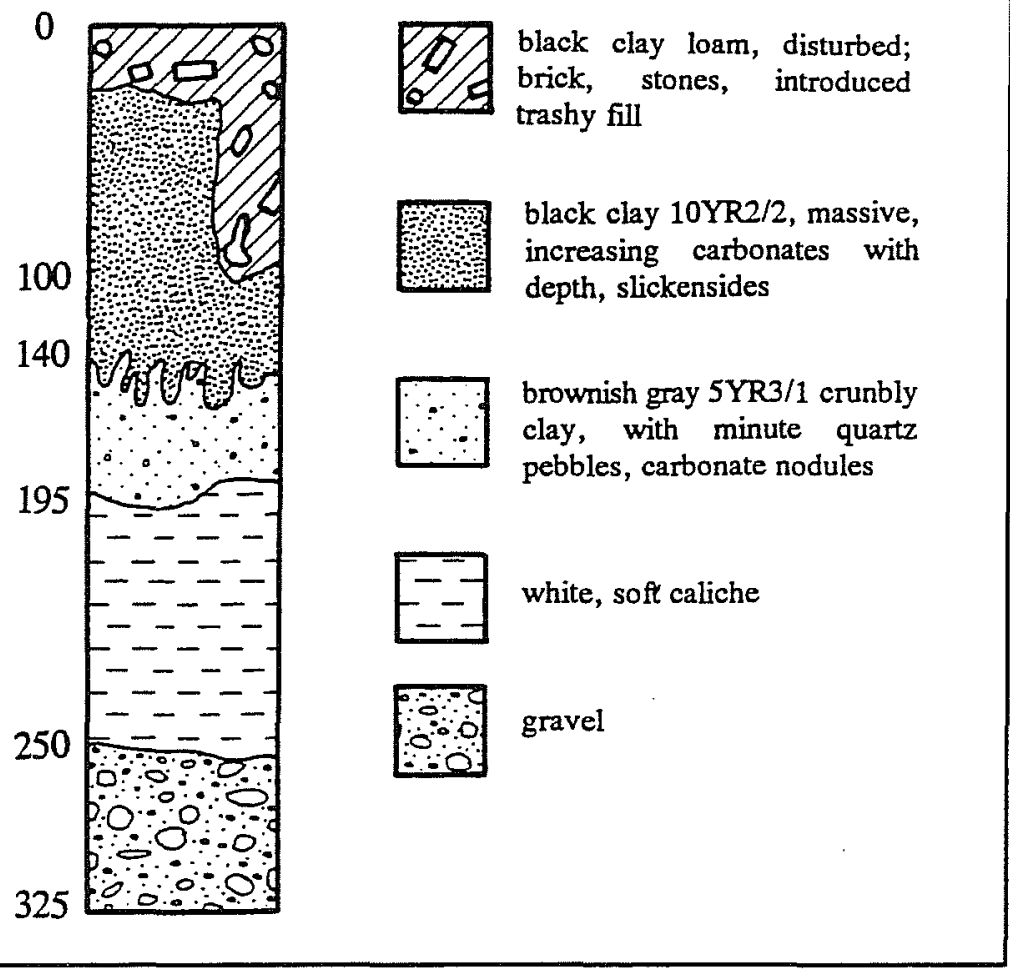

conclusion that the dark clay may be of relevance to archaeological inquiry and that the underlying sediments are probably too old to be of such relevance. The lack of prehistoric cultural evidence in these trenches is consistent with these conclusions as is the observation noted earlier that it appears unlikely that this has been an area of active deposition for many millennia.

It is further stressed that the value of archaeological manifestations occurring in a clay vertisol or grumusol is lessened by the plastic nature of this soil context. The tendency for these soils to cause mixing of cultural objects and disrupt placements such as features is compounded by the greatly reduced suitability of such soil for direct radiocarbon dating.

Figure C-2. Schematic profile, GMBHT 1. Note the Historic-period pit or posthole.

cm b.s.

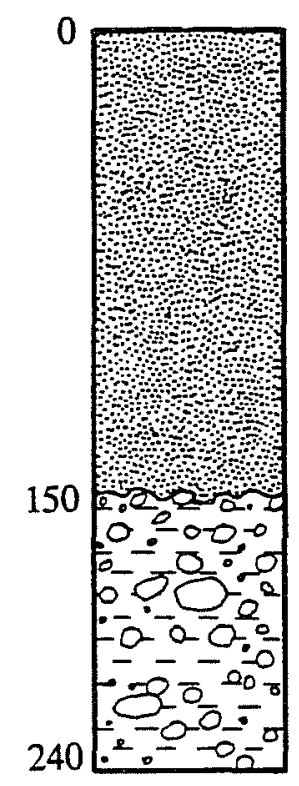

black clay with slickensides gravels with clasts to $10 \mathrm{~cm}$, cherty, zones of carbonate cementation; some caliche clasts to $35 \mathrm{~cm}$

Figure C-3. Schematic profile, GMBHT 2. 
cm b.s.

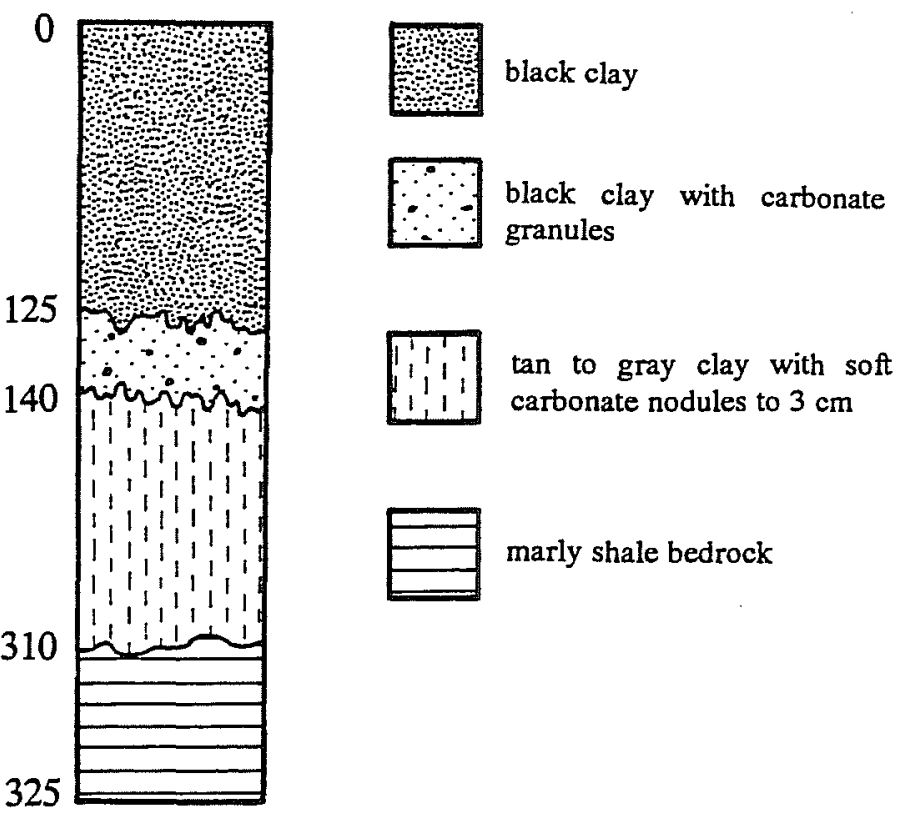

Figure C-4. Schematic profile, GMBHT 3.

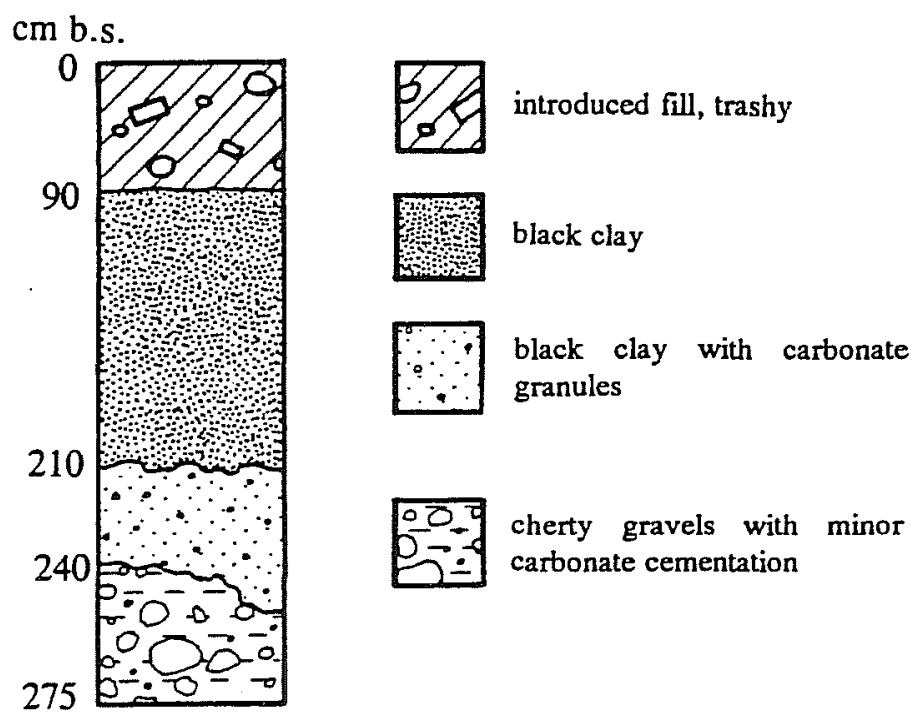

Figure C-5. Schematic profile, GMBHT 4. 
cm b.s.

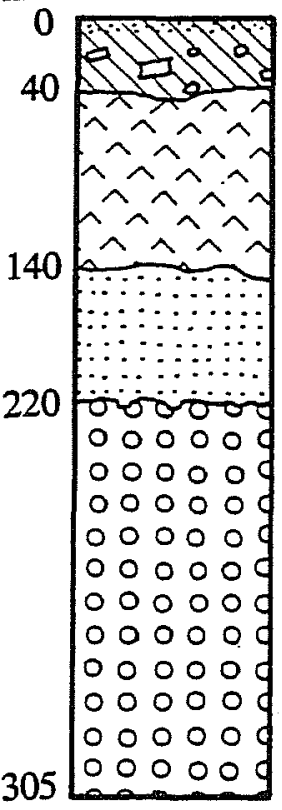

incipient A-horizon, gravel, cultural debris, clay with chert pebbles and cobbles, 7.5YR2/2

$\widehat{\wedge}$ black clay with chert pebbles, cobbles; carbonate nodules in lower $20 \mathrm{~cm}, 5 Y \mathrm{YR} 2 / 1$

::: black clay, abundant slickensides; carbonate nodules $5 Y R 2 / 2$ grading to $10 \mathrm{YR} 5 / 4$ at base where it is siltier

$\begin{array}{lll}5 & 0 & 0 \\ 0 & 0 & 0\end{array}$ silty clay with soft carbonate nodules to $8 \mathrm{~cm}, 10 \mathrm{YR} 6 / 6$

Figure C-6. Schematic profile, GMBHT 5.

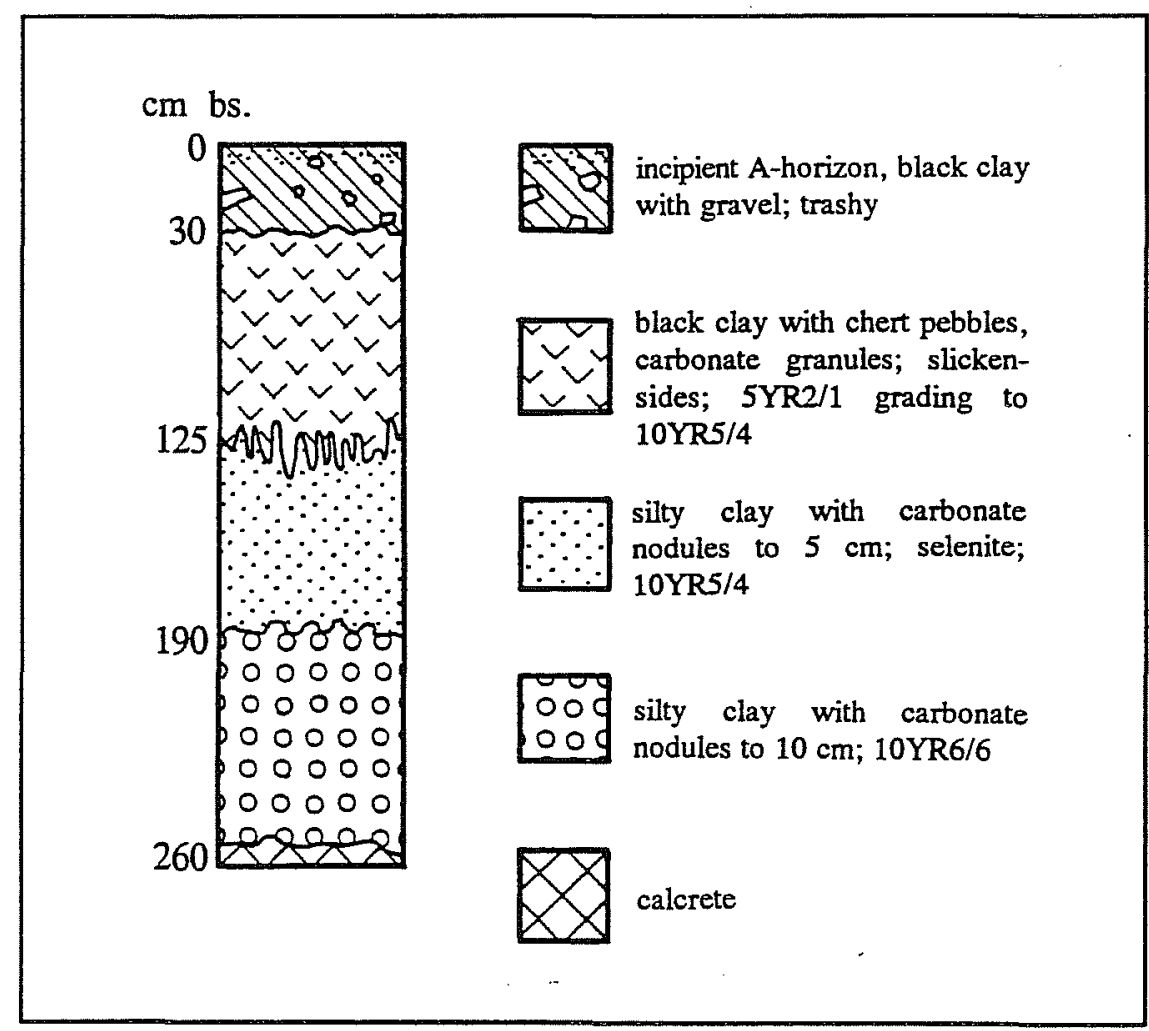

Figure C-7. Schematic profile, GMBHT 6. 
Table C-1. Cultural Material Recovered from GMBHTs 1-6

\begin{tabular}{|c|c|c|c|c|c|c|c|}
\hline \multirow{2}{*}{ Level } & \multirow{2}{*}{ Depth (cm) } & \multicolumn{7}{|c|}{ Backhoe Trenches } \\
\cline { 3 - 8 } & & $\mathbf{1}$ & 2 & 3 & 4 & 5 & 6 \\
\hline 1 & $0-50$ & $8 \mathrm{H}$ & & & $*$ & $24 \mathrm{H}$ & $14 \mathrm{H}$ \\
\hline 2 & $50-100$ & $5 \mathrm{H}$ & & & $10 \mathrm{H}$ & $1 \mathrm{H}$ & $2 \mathrm{~L}$ \\
\hline 3 & $100-150$ & & & & $1 \mathrm{H}$ & & $2 \mathrm{H}, 7 \mathrm{~L}$ \\
\hline 4 & $150-200$ & $1 \mathrm{~B}$ & & & & & $1 \mathrm{~L}$ \\
\hline 5 & $200-250$ & $3 \mathrm{H}$ & & & & $1 \mathrm{~L}$ & \\
\hline 6 & $250-300$ & $1 \mathrm{H}$ & & & & & \\
\hline 7 & $300-350$ & & & & & $1 \mathrm{~L}$ & \\
\hline 8 & $350-400$ & & & & & $1 \mathrm{~L}$ & \\
\hline 9 & $400-450$ & $1 \mathrm{~L}$ & & & & $1 \mathrm{~L}$ & $12 \mathrm{~L}$ \\
\hline
\end{tabular}

\section{References Cited}

Boul, S. W., F. D. Hole, and R. J. McCracken

1989 Soil Genesis and Classification. Iowa State University Press, Ames.

Collins, M. B., G. D. Hall, and C. B. Bousman

1988 Archeological Applications of Geochronological Techniques in Southern Texas. La Tierra 16:14-27.

Duffield, L. F.

1970 Vertisols and Their Implications for Archaeological Research American Anthropologist 75(5):1055-1062.

Geologic Atlas of Texas

1964 San Antonio Sheet. Bureau of Economic Geology, The University of Texas at Austin.

Newman, A. L.

1982 Vertisols in Texas: Some Comments. Soil Conservation Service, U.S. Department of Agriculture, Temple, Texas.

Peter, D. E., and D. E. McGregor, editors

1988 Late Holocene Prehistory of the Mountain Creek Drainage. Joe Pool Lake Archaeological Project, Volume I. Archaeology Research Program, Institute for the Study of Earth and Man, Southern Methodist University, Dallas.

Taylor, F. B., R. B. Hailey, and D. L. Richmond

1991 Soil Survey of Bexar County, Texas. Soil Conservation Service, U.S. Department of Agriculture, Washington, D.C. 
